\title{
PAGURID CRABS OF THE WESTERN NORTH ATLANTIC SOUTH OF CAPE HATTERAS
}

\author{
By \\ MARVIN L. WASS
}

\begin{abstract}
A DISSERTATION PRESENTED TO THE GRADUATE COUNCIL OF THE UNIVERSITY OF FLORIDA

IN PARTIAL FULFILLMENT OF THE REQUIREMENTS FOR THE DEGREE OF DOCTOR OF PHILOSOPHY
\end{abstract}

UNIVERSITY OF FLORIDA

June, 1959 


\section{TABLE OF CONTENTS}

LIST OF PLATES

PREFACE

HISTORICAL REVIEW

MATERIAL STUDIED

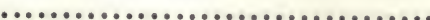

5.

TAXONOMIC CHARACTERS

7.

GLOSSARY

9.

SYSTEMATIC ACCOUNT

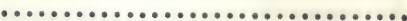

12.

ZOOGE OGRAPHY

256.

SUMMARY

263.

LITERATURE CITED 265.

BIOGRAPHICAL SKETCH 280. 


\section{LIST OF PLATES}

Plate 1. Pylocheles inarmatus.

Plate 2. F1rst gonopod of Paguristonsis humm1 and 14 specles of Paguristes.

Plate 3. Second gonopod of Paguclstoosis humm and 14 species of Paguristes.

Plate 4. Pagur1stes hewatt1, Pagurus schm1tt1, Ceratopagurus cubensis, and Pagurus tenuidactrlus.

Plate 5. Pagurus longimanus and Cestonagurus lineatus. 


\section{PREFACE}

The hermit crabs of the Caribbean Sea and its adjoinIng waters constitute a homogenous faunal group. Most of the species range widely through the region betweon Cape Hatteras, N. C., and the mouth of the Amazon River, with only a few found beyond these limits. While a majority of these species are found in the Gulf of Mexico, the region originally chosen for this study, additional information Indicated that a study of the area from Cape Hatteras to South America would be of greater value. This was particularly true in the light of important collections made on the south Atlantic coast of the United States, in the deep water around Cuba, and off the northeastern coast of South America.

The objectives of this study are to report on new species and to review those previously described from the area. Additional data on distribution is given for most species and more complete descriptions than were previously avallable are provided for several others. Existing descriptions are scattered through numerous publications, many not readily accessible. The only keys to species from the area are for a few small groups. Prerequisite to proper placement of each species is a knowledge of all described genera. Since no complete key to these is avallable, and in 
view of the large number present in the Caribbean, it seemod desirable to include such keys here.

A large share of the credit for the success of th1s undertaking must go to those who collected the specimens over the past century. I am particularly Indebted to Mr. Harvey R. Bullis, Jr., Chlef, Gule Fisherles Exploration and Gear Research, F1sh and W1ldilfe Service, who supplied the largest amount of material. To all who sent material directly to me, whose names are listed in the section on matexlal studied, and to those whose names appear in connection w1th the varlous species, I am most graterul. Dr. Fenner A. Chace, Jr., Curator, Divisi on of Marine Invertebrates, J. S. National Museum, is deserving of special recognition for his encouragement, patience and careful attention to all my requests over the past several years. Dr. Chace arranged for an extended period of study at the National Museum and gave freely of his time during this period. I am also appreclative of the assistance given by Dr. El1sabeth De1chmann, Curator of Marine Invertebrates, Museum of Comparative Zoology, in arranging for a short stay there and for loaning much valuable materlal.

Dr. E. Lowe Plerce, Chatrman of my supervisory committee, has provided assistance and stimulation throughout the entire course of this work. The remalning members of the committee, Drs. R, M. DeWitt, E. S. Ford, E. R. Jones, and J. R. Redmond have provided many helprul suggestions in 
the writing of the dissertation.

Dr. Harold J. Hum of Duke University Introduced me to the study of marine 11 fe and has given frequent encouragement to my studies.

I am indebted to my wife who has typed all of this material at least twice and has been a continuous help in many other ways. 


\section{HISTORICAL REVIEW}

The flrst records of hermit crabs in the ilterature of the Caribbean were Catesby's (1743) descriptions of Cancer. maximus hahamensis and cancelius terrestris bahamensis. of the latter, the only terrestrial pagurid in the West Indies, Catesby wrote, "They belng roasted in their shells are esteemed delicious." These two species, now known respect1vely as Petrochirus bahamensis and Coenobita clvpeatus, are the largest hermit crabs in the western Atlantic. Although Catesby's pre-Linnaean descriptions were republished by George Edwards (1771), it is the names of Herbst (1791) which are accepted for these specles as well as for two others, Calcinus tibleen and Clibanarius sclopetarius, from the same region.

Clibanar1us v1ttatus (Bosc, 1802), a common intertial species of southeastern Unfted States and the mainland coast to Braz11, was the next pagurid described. Thomas Say (1817) became the first American to name a hermit crab when he descr1bed Pagurus longlcarvus and P. poll1ear1s, both of which are abundant along most of the southern and eastern coasts of the United States. Rafinesque's description of $P$. Longicarpus as $P$. truncatulus preceded that of Say by one month but, along with most of Rafinesque's work, was subsequently 1gnored. The name truncatulus has recently been suppressed 
(Holthuis, 1954).

H. MIIne Edwards described several species of pagurids from various parts of the world. Dardanus venosus (H. M1Ine Edwards, 1848) is the only name he proposed which is now used for a Caribbean species. With the description of Clibanarius tricolor (G1bbes, 1850) and C. brastiliensis Dana (1852) all of the Iittoral species of this genus in the western Atlantic became known, although numerous synonyms were to follow.

Will am Stimpson began his work in carcinology at a time when material from depths just below the intertidal zone was beginning to appear in collections. He described six species of pagurids from the western Atlant1c, three of which were only recently rediscovered. His descriptions, while not usualiy supplemented by P1gures, were written with such accuracy that his species are not difficult to recognize. This is fortunate since most of his type specimens are sald to have been destroyed in the Chicago f1re (Chace, personal communieation). After Stimpson's work in the late 1850 's no further valld descriptions of hermit crabs from the western Atlant1c were made unt1l sidney I. Smith (1879) described the widely ranging, deep-sea species parapagurus pllosimanus. Th1s was the Pirst pagurid from the western Atlantie to be described from sublittoral depths. Its deseription was followed by preliminary descriptions of several species from the "Blake" collections by Alphonse Milne Edwards and of a 


\section{3.}

few others by Sm1th. The preliminary work by Milne Edwards was brought to completion when he collaborated with Bouvier (1893) In Purther study of the "Blake" material to produce the most outstanding work on pagur1ds ever done for the western Atlant1c. Th1s report contained complete deseriptions and excellent figures for the 39 specles included. Strangely, only one of the specles described by Milne Edwards and Bouvler (1893) became a synonym of one of the 37 species of pagurids described from both sides of the Amerleas by Benedict (1892). The preliminary descriptions in Benediet's paper were never supplemented by 11 gures or further description. H1s material was obta1ned mainly from the dredglngs of the "Albatross". He later deserlbed several species of Paguristes and a few species in other genera. These were seemingly done with less care than he used in his study of other anomurans.

At the turn of the century well over half of the specles now known from the Car1bbean area had been described. Deepwater specles have been 1 gnored since then except for the description of Prlonagurus cavimanus Chace (1939). The several other species described during this period have all been Intertidal forms. The famous American carelnolog1st, Mary Rathbun, described a single pagurid from the western Atlantic, the unusual clibanarlus verr1111 from Bermuda, a specles which 11ves In calcareous tubes of annelids and actually belongs in the genus Calcinus. E. L. Bouvler (1918) described three small 
4.

species from Cuba; one of the names he proposed has been added to the long list of synonyms in the genus Clibanarius. Waldo L. Schm1tt described two species in the 1930's. Forest (1954) descr1bed an unusual pagur1stes from Mart1nique from a male specimen. This species may belong in another genus since it has only 11 pairs of g1lls. Another Paguristes described by Wass (1956) has been placed in a new genus. 
MATERIAL STUDIED

A large share of ered1t for the suceess of this study must go to the P1sheries research vessels of the U. S. F1sh and W1ld1fe Service. No less than 39 specles were taken by the "Oregon," "Combat," and "S1Iver Bay." Several of these specles were new and most of the remainder were poorly represented in collections. The "Oregon" in its several years of operation has contributed a wealth of material to the National Museum. Through the courtesy of Dr. Fenner A. Chace, Jr., Curator of Marine Invertebrates of that inst1tution, I was able to examine pertinent portions of their collections. Even more specimens were sent directly to me by Mr. Harvey R. Bull1s, Jr., Chlef, Gulf F1sherles Explorat1on and Gear Research, F1sh and W1ldlife Service, Pascagoula, Mississippi. Most of these collections were made in the Gulf of Mexico, of the eastern coast of Florida, and off the northeastern coast of South Amer1ca.

The .. 8. National Museum has a large amount of pagurid crab material, much of which awa1ted 1dent1ficat1on. In this category were the large collectlons made at the Dry Tortugas by Dr. Waldo L. Schmitt and other Invest1gators, which contalned type material for four new species. The collections by the "Pellean" in 1939 and 1940 along the north and east coasts of the Gulf of Mexico and the Atlantic coast south of 


\section{6.}

Cape Hatteras were a source of many new records.

The Museum of Comparative Zoology at Harvard contains the type specimens of nearly all the specles described by A. Milne Edwards and E. L. Bouvier in thelr studies on the "Blake" material. The M. C. Z. also houses the excellent collection of deep-water pagurids from the "Atlantis" Harvard-Havana Exped1tion of 1938 and 1939.

Among Individuals who contributed important amounts of material were the following: Dr. E. Lowe Plerce, specimens from Key West, Fla.; Dr. W1111s G. Hewatt, materlal from the Texas banks; Dr. George D. Grice, Jr., several specimens from northwest Florida; Dr. Ne1I C. Hulings, specimens from the latter area of a species not taken in almost 90 years; $\mathrm{Mr}$. Doyle Folks, many perfect specimens from Seahorse Key, Fla. Mr. Frederlek M. Berry, a large collection of Pagurus politus from the east coast of Florida; Dr. John M. Teal, specimens of Pagurus pollicaris and P. annulipes from Sapelo Island, Ga.; Dr. Charles Goodwin, specimens from the Inst1tute of Marine Sclence at Aransas Pass, Texas; Mr. Robert Christiansen, a large number of Clibanartus from Palm Beach Co., Fla.; Mr. Jorge R. Lopez, about 150 specimens from Mayaguez, Puerto R1co. A two day cruise on the Texas $A_{\text {, and }} M_{\text {, research vessel }}$ "A. A. Jakkula" provided material in which seven specles were found. 


\section{TAXONOMIC CHARACTERS}

\section{Explanation of Procedure}

An attempt has been made to keep descriptive term1nology sinple, consistent and as concise as possible. The external structures used in descriptions are treated in the same sequence for each specles. More attention is given to those structures which best separate the species.

The paper of Forest (1954a) was a s1gn1f1cant factor In the decision to make figures diagnost1c of Important structures. In the interest of brevity telegraphic style 1s used throughout the descriptions.

The list of synonyms for each species is restricted to the different names used and their authors and to references which were not included by Alcock (1905) or in the more complete blbllography of Gordan (1956). Several specles previously considered valid are placed in synonomy.

Descriptions derived from the specimens examined are provided for those genera which contalned more than one specles. Ceratonagurus Yokoya is included although its description is too brief to allow 1ts validity to be ascertained. Galanagurus and Nmpagurus of Boone (1932) are omitted. They may possibly be valid but this cannot be determined by the descriptions given. Cheiroplateg is considered synonomus with 


$$
8 .
$$

Pylocheles, 11kew1se Holopagurus with Isocheles.

Dlagnoses adapted from earlier descriptions are given for specles which were not seen or were not examined in deta1l.

The color guide of Maerz and Paul (1950) was frequent1y resorted to in making color notes but more common names were usually used since it seems unlikely that such a manual will be readily avallable to those who use this work.

$$
\text { Explanation of Measurements }
$$

All measurements are in millimeters and refer to length unless otherwise stated. The width of the shield is taken at 1ts widest point. The third right perelopod was chosen as a representative of the walking legs since those on the right are usually longer than those on the left and the third perelopod is more accessible than the second. Measurements of the segments of this leg were made on the dorsal side. 


\section{GLOSSARY}

Acicle. Flongated scale stemming from second segment of antennal peduncle.

Acuminate. Terminating in a point.

Antennase. Jolnted outer appendage on head.

Antennules. Jointed medial appendages on head.

Anterolateral angles. Angles of shleld located anterior and lateral to center of shleld.

Aporoximated. Placed close together at the midilne.

Arthrobranch. A gill in the median row of the three rows of gills.

Bas1s-1schirum. More or less combined second and third segments of a perelopod.

B1seriate. In two rows.

Branchiae. G111s in pairs numbering from eight to 14.

Carapace. More or less calcifled covering of cephalothorax.

Callosities. Frietion pads on ventral part of thorax.

Cardiac plate. More or less narrow median strip of carapace behind shield.

Chela. PInching claw at terminus of a perelopod.

Chellined. One of anterior pair of perelopods.

Chitinous. Hardened Integument not impregnated with calcium. Cornea. Area at tip of eye darkly pigmented except in a few deep-sea specles.

Corneous. Composed of horny, translucent material.

Coxa. First segment of perelopod.

Crenulate. Margin presenting a wavy appearance. 
Dactrl. Terminal segment of a perelopod.

Dentate. With teeth.

Denticulate. With small teeth.

Distodorsal, distoventral. Parts of a segment most distant from the body proper.

Eaualing. Equal in length or reaching same distance from body.

Eves. Refers to both cornea and eyestalk.

Flagellum. Terminal feeler of antennule or antenna.

Gononods. Palred anterior pleopods which may or may not be functional in transmission of sex products.

Lamellae. Individual plates of a gill.

Lateral teeth. Anterior projections of shield on either

Littoral. Used here to refer to zone of rooted vegetation.

Mafor chela. Largest pinching claw.

Max1111peds. One of last three palrs of mouth parts.

Merus. Fourth segment of a pere1opod.

Minor chela. Smaller pinching claw.

Monotyo1e. Only one species in a genus.

Operculiform. Shaped so as to close an aperture.

Operculum. Part or combination of parts used to form a door. for an aperture.

Ophthalmic ring. Median structure between bases of eyestalks. Penult1mate. Next to last.

Perelonods. Last I1ve pairs of thoracic appendages.

Phrlilobranchlate. G111 lamellae loaf-l1ke.

B120se. Hair which is very fine. 
Pleonods. Abdominal appendages anterlor to uropods. Pleurobranch. G111 from Innermost of three rows. Plumese. Halr which is fine and feather-like. Podobrench. G111 from outermost of three rows. Pollex. Thumb formed by prolongation of propodus. Pestcervical, Located posterior to shield. Propodus. Penultimate segment of a perelopod. Punctate. Surface presenting small rounded depressions. Rami. Terminal segments of unpalred pleopods. Rase. Patch or row of scales. Bostrum. Median anterior projection of shield. Setae. Here used to refer to all halrs or bristles. Spinules. Sharp projections not large enough to be considered spines.

Sternum. Ventral portion of a thoracic somite.

Strl1form. Narrowed distally.

Subapleal. Ventral to apex.

Subequal. Nearly equal.

Subsymetrical. Nearly symmetrical.

Sulcus. Groove or depression.

Telson. Posterior unpaired appendage of abdomen.

Tuberculate. Covered with small projections lacking spines. Iniseriate. Composed of one row.

Uronods. Palred posterior appendages of abdomen. Walking legs. Second and third pair of perelopods. 


\section{SYSTEMATIC ACCOUNT}

\section{Key to Fam1lies}

The classification of MacDonald, et al, 1957, 1s used here. However, only the four families involved in this study are included in the key.

1. External maxillipeds approximated at bases. Superfam1ly Coenob1to1dea................................2. External maxillipeds widely separated at bases. Superfam1ly Paguro1dea......................... Pagur1dae.

2. Body and appendages symmetrical, except for variation In telson of Mixtopagurus. Abdominal terga calcified and contiguous..........................Pylochelldae.

Palred appendages never present on all abdominel segments. Abdomen membranous, terga never calcilled..3.

3. Antennuler Plagellum ending bluntly......... Coenob1t1dae. Antennular flagellum ending in a rllament...... Dlogentdae. 
Fam1ly Coenob1t1dae Latre1lle

Genus Coenob1ta Latre11le

Coenob1ta clrneatus (Herbst)

Cancer Mlogenes Catesby, (1743) 1771, p. 33, pl. 33.

Cancer clyneatus Herbst, 1791, p. 22, p1. 23, 11B. 2A, B.

Pagurus elmeatus Fabrielus, 1798, p. 413.

Coenobita dlogenes Latre11le, 1825, p. 277.

Coenob1ta clrpeatus Hilgend orf, 1869, p. 98. -Monod, 1939, p. 560. --Chace, 1956, p. 153.

REMARKS: Gcrdan, 1956, p. 311, placed C. dlogenes in synonomy with elvneatus. However, in doing so she also included the references since Alcock (1905) to a specles from Malaysla which has been confused with the West Indian species because of Herbst's original designation of his species as having come from the East Indes (Schmitt, 1935). Most of Miss Gordan's references apply to the Oriental species which is properly known as $\mathrm{C}$. hilgendore1 Terao. Those which apply to C. elvoeatus Herbst are Rathbun (1919), Schmitt (1924 a and b), Pearse (1932), Boone (1935) and Schm1tt (1935).

MATERIAL EXAMINED; Two hundred and seventy-five specimens from nine locallties.

The USNM has a large number of specimens of this species, only a few of which, plus some from other sources, are 11sted below. 
Florida: Near Lake Kissimmee, Fla,; A. M. Reese; 1

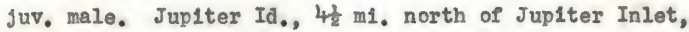
Aug. 6, 1957, R. Christensen; 2 males. Sand Key, 7 m1. southwest of Key West, July 23, 1957, E. L. Plerce; 2 males taken allve lived unt1l Dec. 11 when they died from belng overheated. Tortugas; Dec, 24, 1912, "Fish Hawk", I large male, 11 in shells, "sand herm1t crabs, very abundant".

Texas: Tuxpan, "Dr. Lincecum, 1 juv. In shell. Mex1co: Vera Cruz, Boca Andrea, Dec. 26, 1954, J. Tamsitt; 1 male.

Bahamas: Albert, Fortune Id.; July 13, 1930, 241 juveniles; $P_{\text {. Bartsch. }}$

Jama1ca: Rock cliffs west of D1scovery Bay; June 13, 1958, 8 females, 6 males (largest specimens in shells of Lirong Dica Linnaeus.

British Honduras: Belize, H. S. Howe, I in Melongena shell.

RANGE: Bermuda (Haas, 1950), Palm Beach Co., Fla., Tortugas Ids, and Texas, south to Venezuela. Terrestrial and 11ttoral.

DESCRIPTION: Left cheliped mass1ve; chela articulating almost horizontally with carpus, length only a little greater than helght. Fingers short, heavy; with sharp calcareous teeth. Faces of all pereiopods covered sparsely but regularly with small dark tubercles. Minor cheliped small and laterally compressed but not weak. Cutting edges of IIngers 
sharp, hoof-shaped tips corneous. Carpl of both chelipeds with a distodorsal calcareous spinule on the inner margin. Palms w1th a dense brush of fine hair on inner dorsal surface. Minor chela with numerous setae below.

Walking legs strong, those on left heavier and shorter than those on right. Propodus of second on left very deep w1th a row of fine teeth on ventral and distal margin; dactyl short, swollen and with a ventral margin of fine teeth on proximal two-thirds. Dactyls with fine tufts of short dark setae dorsally and laterally. Long yellow setae. ventrally, very sparse in second on left.

Fourth perelopod chelate, short, laterally compressed; a large rasp of minute scales covering distal two-thirds of propodus. Dactyl rudimentary, tooth-11ke. Fifth perelopod chelate; not compressed; chela long, with a fine rast on outer surface.

G111 palrs seven, each g11l with two rows of complete leaf-11ke lamellae. Outer maxillipeds approximatod. Separation of coxae of perelopods increasing evenly to flfth; coxae of latter approximated, male openings on posterior, guarded by tufts of fine, dark setae. Abdomen membranous, covered with short, fine setae. Posterior abdominal appendages reduced, telson feebly blfurcate.

COLOR: Male from Jamaica in formalin two months. Carapace and proximal parts of walking legs prune purple, latter shading through pansy and maroon purples to buff 


\section{6.}

near horny tips. Chelipeds malnly prune and plum purple to finger tips where white teeth and tubercles arise from a background of hellotrope purple. A Pleshy ochraceous fold on distal margin of carpus of main chellped. Safron yellow setae along margins of perelopods and other parts of body. Tips of antennular flagella scarlet vermillion. Smaller specimens lighter in color.

MEASUREMENTS (mm.), Shleld, length 19, ant. width 8, post. width 15 ; carapace 35 , eyes 7 ; left chela, length 32 , height 26, w1dth 15.5 , dactyl 17.5, gape 10, right chela, length 17, height 13.5, width 7.5, dactyl 10.5, gape 7; third right pereiopod, merus 14, carpus 15.5, propodus 19 , dactyl 27.51, third left perelopod, merus 13, carpus 14.5 , propodus 16 , dactyl 22.

REMARXs: The characters given in the description will frequently apply to the genus. The several species are tropleal with the center of abundance in the Indo-Pacil1c. 
Fam1ly Pylochelidae Bate

Body crayfish_like, symmetr1cal; abdomen covered by contiguous caleified tergal plates. Second and third perelopods long, fourth and fifth short, subchelate. Eyes variable, well_developed in some specles, much reduced in others, Eggs large, few in number, protected by tall fan.

The genus Chelroplatea Bate is here united with Prlocheles, as was previously suggested by Milne Edwards and Bouvier (1893) and Alcock (1905). There has been shown to be a gradation from specles w1th a well-p1gmented cornea to those with the cornea lacking pigment, the main character upon whlch Cheiroplates was established.

Key to Genera

1. External maxillipeds cheliform............. Prlocheles. External max1llipeds not cheliform..................

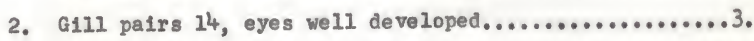
G111 pa1rs 12, eyes reduced and pale..... Paraprlocheles. 3. Chelae forming an opereulum.............. Pomatocheles. Chelae not forming an operculum..............1xtopagurus.

Genus Prlocheles A. Milne Edwards

Shield and posterior part of carapace united. Eyes 
varying from prominent to reduced; cornea lacking pigment In species formerly assigned to Chelroplatea. Eyo scales reduced or absent.

Chelae and produced anterior parts of carp1 form an operculum.

\section{Key to Species}

1. Eyes less than half as long as shleld.................

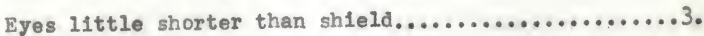

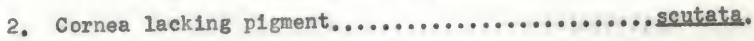
Cornea pigmented........................ Inarmatus.

3. Dorsal row of spines in carpus parted at the midline by a furrow. part1tus.

Transverse dorsal row of spines on carpus continu. ous. agassizi.

Prlocheles agassizi A. Milne Edwards Pylocheles agassizi A. Milne Edwards, 1880, p. 38. --Gordan, 1956, p. 339.

RANGE: Barbados to St. Lucia; 154 to 200 fms.

DIAGNOSIS: Chelipeds armed on margins of propodus and on carpal crest with strong spines. Crest of carpus unbroken by a median shallow furrow. Otherwise this species is very near $\underline{P}_{\text {. partitus. }}$ 
Pylocheles 1narmatus n. sp.

MATERIAL EXAMINED; Male holotype, MCZ 126677; $22^{\circ}$ o ' $\mathbb{N}_{.,} 81^{\circ}$ 08' W.; 150-170 fms.; Feb. 25, 1938, "Atlant1s" sta. 2963B.

RANGE: Type locallty, Bahla de Cochinos, south of Santa Clara Province, Cuba.

DIAGNOSIS: Eyes short, less than half as long as shleld; chelipeds unarmed.

DESCRIPTION: Carapace well calcifled dorsally, g1ll covers strong. Frontal margin indented medially, raised and less indented behind eyes. V-shaped cervical groove approximately blsects carapace. Carapace lightly setose in depressions and on numerous lateral punctae.

Eyes small, stalks somewhat narrowed between bases and cornea; latter Indian red and with a honey_combed appearance. Antennular peduncles exceed eyes by terminal $21 / 3$ segments. Antennal peduncle exceeds eyes by almost $11 / 2$ segments. Second segment with distal half raised, a spin ule below base of acicle, outer projection strong, not spin. ous. Ac1cle crested with ten or more denticles on dorsal margin. Flagellum short, scarcely reaching fingers of chelae.

Chelipeds narrow, of medium length. Anterodorsal surface of carpus raised, produced forward. Dorsal surface of chela pubescent, silt laden; margins marked by even 
denticles hidden by dense setae. Fingers closing only on distal third, with a wide proximal gape; tip of dactyl a strong bifld tooth closing well inside stout calcareous tip of pollex and meeting a strong tooth between tip and wide gape. Second and third perelopods sparsely setose on margins; dactyls with two rows of short setae dorsally and a row of longer setae composed of several separate combs on lower surface; corneous tips yellow, decurved. Carpus of fourth pereiopods with a strong anterodorsal denticle protruding from inner side of propodal base. Propodus also bears an anteroventral spinule. Dactyl short, stout, with numerous tufts of setae. Fifth perelo. pods subchelate, dactyl minute; a rasp on dorsolateral surface of propodus.

First pair of male appendages feeble, with terminal segment broad, spatulate. Second pair much stronger, with a stout, anterior denticle on second segment; terminal segment heavy, curved, with a spatulate tip. Abdominal somites punctate; sixth has a small, square notch at termi. nal midpoint. Terminal segments of uropods have strong propodal rasps composed of short, sharp spines as on propodi of fourth and fifth perelopods. Base of telson with a bare, fleshy spot near each anterolateral margin; terminal flap broad, oval.

MEASUREMENTS ( $\mathrm{mm}$. ): Body length 70 , carapace, length 18.5, width 15.0; shield 11.0; eyes 4.4, chela, length 22.5, 
width 8.0 , dactyl 8.5 ; third right perelopod, basis-1schium 5.0 , merus 11.2 , carpus 8.5 , propodus 9.5 , dacty 19.7 .

\section{Prlocheles partitus Benediet}

Prlocheles part1tus Bened1ct, 1901, p. 775, 11gs. 5,6. - -Gordan, 1956, p. 340.

MATERIAL EXAMINED: Three specimens from Cozumel Id., Yucatan. Male type, labeled "Prlonagurus nart1tus $B_{\circ}$, Cozumel, In sponge, Jan, 29, 1885", the "Albatross" made 4 stations that day at approximately $20^{\circ} 19^{\prime} \mathrm{N} . .87^{\circ} 03^{\prime} \mathrm{H}, \mathrm{s}$ at depths between 137 and 231 fms, sane locat1on, "Albatross" sta. 2359, 2 ovig. Pemales.

RANCE, Known only from type local1ty.

DIAGNosis, Parts of perelopods included in operculum well armed. Eyes 11ttle shorter than shleld, corneas swollen. Antennal flagellum equaling chelipeds.

DESCRIPTION: Carapace well calclfled, slightly narrowed anteriorly. Gastric region smooth, somewhat elevated; bordered anterlorly, except in middle, by a row of setae. Front with four spinous teeth; median separation somewhat longer, but less recessed, than lateral ones. Carapace sparsely pubescent lateral to shield, in cervical groove and posteriorly. Cervical groove in shape of a shallow V.

Eyes short, cornea swollen; eye scales absent. An-

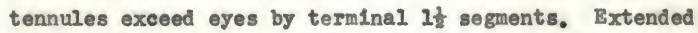




\section{2.}

flagellum reaches dactyl of chela. Second segment of an. tennal peduncle with elevated boss bearing two spinules posterior to distal spine. Acicle with about 13 spinvies forming a serrate edge ventrally; two sharp spines on dorsal surface just behind terminal spine. Flagellum moderately ciliated, nearly equal to chellpeds. Chelipeds equal, carpus and chela forming an operculum bordered by calcareous spines. Carpus with distally protruding crest equal to onethird of total length of carpus. Carpal crest with six large spines on leading edge, three on each side of deep median groove; lateral edges with much smaller spines; crest almost making a $90^{\circ}$ angle with face of manus with latter fully raised. Approximately ten spines appear on Inner edge of hand, 25 on outer margin and ten on dactylar margin. Surface of hand covered with evenly rounded dent1cles occurring malnly in rows. Bases of denticles setose; longest and densest setae marginal. Cutting edges of IIngers with heavy, calcareous teeth fused except for proximal two of dactyl. Tip of latter fits into groove between tip of pollex and shorter, ventral tooth. Chela moving in vertical plane with carpus.

Second and third perelopods without spines; sparsely setose dorsally and ventrally, with small clusters of setae rising from sparse punctae on all dactylar surfaces. Fourth perelopods with a single row of corneous-tipped scales form. ing a rostrum. Fifth perelopods with subchelate rasp 
covering about half of dorsal surface of propodus adjacent to leading edge. Dactyl small, shorter than propodal width.

Gonopods long, distal segments spatulate. Sixth ab. dominal segment with a raised sternal band about one mm. wide. Uropods with a sharp spine on posterior edge on e1ther s1de. Abdominal plates, uropods and telson evenly setose except on rasps of uropods.

Eggs carried by one female number about 15 , each 1.5 mm. In diameter.

MEASUEBMENTS (mm.): Body length 35, carapace, length 11, width 9.3 ; eyes 4.8 ; sh1eld 6.7 ; chela, length 11.3, widh 5.8 , dactyl 4.7 .

\section{Prlocheles scutata (Ortmann) n. comb.}

Chiroplates scutata Ortmann, 1892, p. 275, p1. 12, Iig. 4.

Chiroplataen scutata Alcock, 1905, p. 153.

Cholroplatea scutata Boas, 1926, p. 45. _-Gordan, 1956, p. 307 .

DIAGNOSIS: (after Ortmann, 1892) Carapace nude; ros. trum blunt, rounded; all three anterior teeth t1pped with a Iine denticle. Eyes conical, shorter than peduncles of antennules.

Carpus with a dentated crest; face of chela finely setose and spiney. Walking legs sparsely setose, dorsal 
24.

margins of carpi and propodi finely spined.

This species was described from a male taken in the "Gulf of Mexico" by Alexander Agassiz and sent to Ortmann. It is very likely from a considerable depth.

Genus Mixtopagurus A. Milne Edwards

Mixtonagurus naradoxus A. Milne Edwards

Mixtonagurus paradoxus A. Milne Edwards, 1880, p. 39. -_Gordan, 1956, p. 319.

Mixtonagurus g1111 Bened1ct, 1901, p. 777, f1g. 7. -_Gordan, 1956, p. 319.

NATERIAL EXAMINED: Eleven specimens from elght sta. t1ons. Holotype male (at MCZ), Barbados; 200 fms.; "Blake" sta. 291; in Xiphosure shell; body about $2 \mathrm{~cm}$. long.

off North Carolina: $34^{\circ} 39^{\prime} \mathrm{N}$, , $75^{\circ} 33^{\prime} \mathrm{W}$; $107 \mathrm{Ims.;}$ "Albatross" sta. 2601, 1 Pemale (type of ‥ g1111 Benedict).

"Off St. Aueustine: 170-190 fms." probably "Combet", I female.

Gulf of Mexico: $29^{\circ} 42^{\prime} \mathrm{N} ., 88^{\circ} 25^{\prime} \mathrm{W}, 321 \mathrm{fms}, 3$ Feb. 14, 1950, "Oregon" sta. 260, 1 male. $27^{\circ} 48^{\prime} \mathrm{N}, 94^{\circ}$ 40 ' W.; 200 fms.; May 6, 1956; "Oregon" sta. 1501; 1 ov1g. female.

Key West. Fla.: $24^{\circ} 21^{\prime} \mathrm{N} ., 81^{\circ} 52^{\prime} W_{0} ; 109$ fms.; Feb. 19, 1902, "F1sh Hawk" sta. 7282; 1 male, 1 Pemale.

Guadeloune: 175 fms.; I juv. Pemale, MCz 6327. 
off mouth of Orinoco River: $09^{\circ} 45^{\prime} \mathrm{N} ., 59^{\circ} 45^{\prime} \mathrm{W}$. 200 fms.; Nov. 3,4; 1957, "Oregon" stas, 1984 and 1989, 1 male, 3 females ( 1 ovig.). Female from sta. 1984 was found in a shell of Tugurium longlevt.

RANGE, North Carolina and Gulf of Mexico to mouth of orinoco river; 213 to 200 fms. (only one record above 107 fms.).

DIAGNOSIS, Large species with abundant setae on most appendages and on abdominal margins. Eyes long, stalks curved, cornea not swollen. Symmetry of telson highly varlable.

DESCRIPTION: Shleld as wide as long, strongly indented near each posterolateral border. Rostrum obtuse, almost equal to lateral teeth; latter connected by a fine marginal line. Each anterolateral margin marked by a heavy, rounded ridge bordered by a deep cleft. Cardiac plate somewhat funnel shaped. Lateral regions of carapace with numerous tufts of setae. G1ll cover leathery.

Eyes long, a little swollen at each end. Eye scales minute, tipped by a spinule. Antennular peduncle slightly exceeds eyes. Antennal peduncle not reaching cornea; base with strong, outer spine; second segment w1th diagonal, median depression, three or four spines on outer projection, a spinule or denticle on inner angle; third segment with a distoventral spine, fourth with a distodorsal. Acicle armed w1th numerous spines, more on inner side than on outer. 


\section{6.}

Aclele and projection of second segment bear long, abundant setae dorsally. Flagellum short but easily reaching chela; densely setose.

Flrst three perelopods well armed, densely setose on the three terminal segments. Merus of chelipeds with distodorsal marginal and submarglnal rows of spines, other spines on ventrolateral margins, Carpus armed w1th ten or more spines on inner dorsal surface; these may be in two rows or 1rregular. Shorter spines appear on distodorsal margin. Inner dorsal margin of palm armed as in carpus; remaining surface with numerous blunt spines becoming shorter distally. Closed fingers with even gape to black, horny tips; latter hoof-shaped, that of dactyl apparently composed of several welded teeth proximally.

Second perelopods with varying numbers of strong spines on dorsal angles of carpus and propodus; spines obscured by stiff setae. Dactyl with strong tufts of setae except on inner margin, claws sharp, continuing dorsal curvature. Third perelopods similar to second but with fewer spines on carpus, none on propodus. Propodus of fourth perelopods with a large ventral rasp two scales wide proximally, about ten distally. Dactylar rasp a row of about 12 scales. Pro. podus of f1fth perelopods short, broad, with a rasp on distal four_fifths.

Female gonopods approximated at bases as are first pair in male. Second pair of male strong, with a short 


\section{7.}

exopod; endopod broad, spatulate distally. Telson varles from symmetrical, or nearly so, in males to strongly asymmetrical in females where it apparently contributes to formation of a broad pouch by elongation of the left lobe. Female carries several hundred eggs $1.4 \mathrm{~mm}$. In diameter at the eyed stage. 
Family Diogenidae Ortmann

The approximation of the third maxillipeds at the aidIne is the main character separating this family from the Paguridae, Other characters which generally apply are given in the following diagnosis.

Shield equal to or longer than cardiac plate; latter narrowed posteriorly. Transverse groove present just behind frontal margin. Gastric region well defined. Posterior parts of gill covers often forming calcareous plates.

Eyes frequently long and narrow; cornea moderately dilated in a Iew genera. Eye scales mediumly separated or or closely spaced; often tipped with several fine spinules. Antennular peduncle usually equaling or exceeding eyes. Antennal peduncle armed on second segment with an inner denticle and an outer spine; acicle dentate or spinous on sides as well as at tip.

Chelae equal or left is larger, except in Petroch1rus, in which right is a little larger. Articulation of chela with carpus horlzontal or oblique, never vertical. Chel1peds and walking legs usually well armed, more or less setose. Propodal rasp of fourth perelopods always composed of several rows of scales; fifth pereiopods chelate or sub. chelate, with a well developed rasp.

Two pairs of gonopods present on males in three genera, on females in two. Brood pouches present in two genera. 
REMARKS, This family contains only 14 genera and the characters which separate them are often different from and less clearly defined than those which separate genera in the Paguridae. The great majority of the specles are 11ttoral or confined to the upper shelf, and are most abundant In warm temperate and troplcal reglons. Pagurids found on reefs usually belong to this fam1ly. While many are small, some, such as those in the genus Petrochirus, are the largest aquatic pagurids. E1ght genera and at least 29 species are present in the western Atlantic above the equator.

MacDonald, at al., (1957) present convincing evidence for the separation of this former subfamily as a complete family, based on larval development as well as on well known adult characters.

Key to Genera of the World

1. Paired appendages present on first and second abdominal segments of male..........................2.

First and second abdominal segments of male lacking palred appendages..................................4.

2. Paired appendages on first abdominal segment of female, brood pouch well developed or, rarely, rud 1mentary.......................................

First abdominal segment of female without paired appendages; brood pouch lacking............. Paguristorsis.

3. Fourth pair of perelopods chelate, eyestalks stout.......

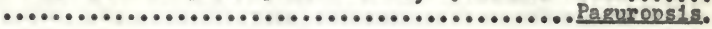


Fourth pair of perelopods not chelate, eyestalks slender.............................. Paguristes.

4. Chellpeds equal or subequal...................... Chelipeds unequal, right or left larger..............

5. Chelipeds modifled to form an operculum........ Cancellus. Chelipeds not forming an operculum................6.

6. Fingers acuminate, antennal flagellum short, with two rows of long, fine setae. G11l pairs 13...... Isocheles. Fingers spooned or hoof-shaped at t1ps; antennal Plagellum moderately long, nude. Gill pairs $14 \ldots . . .7$.

7. Finger tips spooned; most specles 11ttoral, one found

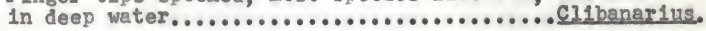
Finger tips hoof-shaped; most species sald to be fossorlal.................................niculus.

8. R1ght chel1pod percept1bly larger than left............. Petrochirus.

Left cheliped larger than right....................

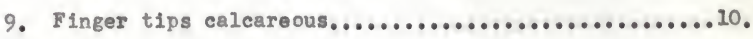

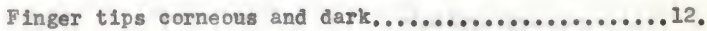

10. Rostrum replaced by a movable scale on ophthalmic somite............................... Diogenes.

Rostrum not replaced by a movable scale..............11.

11. Antennal flagellum nude; left hand bare or nearly so....

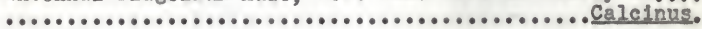

Antennal flagellum and left chela setose............... Trogionagurus.

12. A stridulating apparatus present on inner face of chela .................................... Trizonagurus. Inner face of chela without a stridulating appratus...13.

13. Endopods of maxillae each with a well developed lateral appendage. Female with unpalred pleopods biramous....... .................................. Pseudosagurus. 


\section{1.}

Endopods of maxillae lacking lateral appendages. Females with first three unpaired pleopods tri. ramous.......................... Dardanus.

\section{Genus Calcinus Dana}

\section{Calcinus t1blcen (Herbst)}

Cancer t1bicen Herbst, 1791, p. 25, p1. 23, 11g. 7. Pagurus t1bicen Bose, 1801, p. 78.

Pagurus sulcatus Milne Edwards, 1836, p. 279.

Calcinus sulcatus Stimpson, 1858, p. 234. --Gordan, 1956, p. 305.

Calcinus eormosus Neumann, 1878, p. 31. --Gordan, 1956, p. 304 .

Calcinus tibicen M1ers, 1879, p. 491. --Gordan, 1956, p. 305 .

MATERIAL EXAMINED, Twenty-eight specimens from five localities.

Tortugas: (Specimens collected by W. L. Schmitt) Southern end of Bush Key Reef; July 14, 1932, 4 males, 6 females (2 ovig.). July 31, 1924, 3 males, 2 ovig. females. July 5, 1932, 2 males, 1 Pemale. Under rocks on outer side of B1rd Key Reer; July 11, 1930; 1 male, I ov1g. Pemale. June 21, 1932; 1 female, "Chelipeds malach1te green except usual yellow fingers and margins to joint."

Key West: Aug. 21, 1958; E. L. Plerce; 2 males, 2 ovig. females. 
Bahamas: Cat Cay, May 4, 1958; J. Randall, 1 male. Ha1t: Reef east of TLerra Baha Road, Tortugas Is., $\frac{1}{2}$ Im.; Mar. 21, 1937; W. L. Schm1tt; 1 male. Martinioue: Smith Bay, reef; Apr. 25, 1957; W. L. Schm1tt, 1 male.

DIAGIOSIS: Relatively small reef species. Left chel1ped massive. Body and first three perelopods nude except ventrally on dactyl of walking legs. Propodus of third left perelopods with a broad outer suleus.

DESCRIPTION: Shleld evenly convex, glabrous; provided w1th numerous fine punctae. Postcervical part of carapace membranous. Rostrum triangular, not reaching eye scales; lateral teeth lacking. Eyes long, slender, heaviest at base of stalk; cornea little swollen. Bye scales small, convex, narrowly separated. Antennular peduncle reaching narrow white band behind cornea, those of antennae a little shorter. Second segment of antennal stalk with a minute Inner denticle, outer angle blfid. Acicle unusually short, not reaching midpoint of eyestalk. Flagellum nude, barely reaching dactyl of chela; acicles short.

Chellpeds strong, left massive; both unarmed. Finger tips calcareous, hoof_shaped. Walking legs strong, sub_ equal to chelipeds. Dactyl much shorter than propodus. Horny claw large, sharp. Propodus of th1rd left perelopods with an outer, subdorsal sulcus with fine granular ridges. (This structure is overhung by a sharp, dorsolateral ridge 
and compares with the structure found on the same segment In Darianus. It may be a stridulating apparatus).

Fourth perelopods chelate, short, stout; fleth pair long and narrow. The four unpalred pleopods of the male unusually strong, biramous. Telson broad, subsymetrical, unarmed, fringed with setae.

COLOR: Male from Cat Cay after 6 months in formalin. Following parts scarlet, thickly peppered with white punctae: Shleld, proximal four-fifths of eyestalks, second segment and acicle of antennal peduncle, first three perelopods (except dactyl and tips of chelae), and broad bands on merus of fourth perelopods. Color darkest and white spots most numerous on chelipeds. Eyestalk with a band or white next to cornea. Eye scales wh1te. Tips of chelae shading to white. Dactyl of walking legs white with a wide median band of scarlet.

MEASURENents (mm.): Male from Cat Cay. Shield, length 5.4 , width 4.0 ; carapace 9.7 ; eyes 4.4 ; left chela, length 7.3 , width 4.9 , dactyl 4.8 ; right chela, length 5.0 , width 3.9, dacty1 2.5, third right pereiopod, basis_ischium 2.3, merus 4.2 , carpus 3.1 , propodus 4.8 , dacty 13.5 .

\section{Genus Cancellus H. Milne Edwards}

Body and appendages symmetr1cal, shortened, adapted for living in siliceous sponges or rocks. Shield glabrous, 


\section{4.}

broader than long; frontal projections nearly equal. Cardiac plate as broad as long. Abomen membranous, spherical, shorter than carapace.

Eyes moderate, shorter than shield, cornea not d1. lated. Eye scales small, simple, widely spaced. Antennular peduncle strong, equaling eyes; that of antennae short. Second segment of latter with a sharply projecting shelf on distodorsal half, with spinous denticles on inner and outer angles. Acicle with three spines, including terminal, on anterolateral edge; a short spine on inner proxiral edge. Terminal segment reaches little more than halfway on eyestalk. Flagellum feeble, not exceeding that of antennule.

Chelipeds massive; chelae triangulate in cross section, deeper than wide, crested on inner margin. Carpus and chela of chelipeds and last three segments of second pereiopods form an operculum, segments of the second pair curving around the chela. Carpus of chelipeds oblique, seeming little movable. Fingers extremely stout and short; tips dark_corneous, blunt. Dactyl of walking legs shorter than propodus. Female openings large, rounded. Sternum between third pair of coxae with a round boss topped by fine setae.

Fourth perelopods short, chelate; propodus little longer than broad, with circular rasp covering distal two. thirds of surface. Dactyl short, occupying little more than middle third of anter1or edge of propodus, with four minute scales behind tip. A tiny calcareous tubercle on 
palm at base of dactyl. Fifth perelopods chelate, with a rasp about three times as long as broad and covering entire dorsal edge of palm. Fingers flattened, lightly spooned; a minute rasp on dactyl.

Posterior abdominal plate varlously sculptured and armed, telson broader than long, bent under so that abdomen Is little exposed ventrally.

Alcock (1905) quotes M1lne Edwards and Bouvier as stating that the gill pairs number 14 and that of the two arthrobranchs on the third max1llipeds, one 1s rudimentary and the other non-plumose. However I can fInd but 13 pairs, s1x of which are quite rudimentary and only 6 of which have two rows of lamellae. They are disposed as follows: A pair of rudimentary arthrobranchs on the third maxillipeds and each of the first two pairs of perelopods; third pereiopod with one complete arthrobranch and a second of a fow lamellae in a single row, also a complete pleurobranch; fourth pere10pod w1th four complete g11ls, a podobranch, two arthrobranchs, and a pleurobranch; the last segment has a large pleurobranch. While the third maxillipeds are closely approximated and the gill formula similar to that of other genera in the Dlogenidae, this genus seems to be the most aberrant member of the fam1ly. The three specimens of as many species known from the Caribbean region can be separated by the following key. Only additional material will determine the validity of the three. 
Key to Species

1. Posterior abdominal plate, basal segments of uropods, and opercular parts ornately sculptured; abdominal

plate armed on margins with many short spines... prnatus.

Abdominal plate and opercular parts not especially sculptured or as well arned; opercular surface more llat.

2. Abdominal plate armed lightly.............. snongicola. Abdominal plate unarmed.....................tannerl.

\section{Cancellus ornatus Benedict}

Cancellus ornatus Benedict, 1901, p. 772, 11g. 1,2. --Gordan, 1956, p. 306.

MATERIAL EXAMINED: Holotype fenale; "between delta of Mississippi and Cedar Keys," $28^{\circ} 45^{\prime} \mathrm{N} ., 85^{\circ} 02^{\prime} \mathrm{W}$.; $30 \mathrm{fms}$; "Albatross" sta. 2405, gray sand, broken coral.

RANGE: Known only from type.

MEASUREMENTS (mm.): Shield length 6.0, width 6.5; carapace 8.2; eyes 4.6; chela, length 7.3, width 2.8, thickness 4.0 , dactyl 2.7.

\section{Cancellus snongicola Benedict}

Cancellus srona1cola Bened1ct, 1901, p. 773, f1gs. 3,4. --Gordan, 1956, p. 306.

MATEFIAL EXAMINED: Holotype male, USIM 9549, off Arrowsmith Bank, Yueatan; $20^{\circ} 59^{\prime} \mathrm{N} ., 86^{\circ} 23^{\prime} \mathrm{W}$; $130 \mathrm{fms.}$ 


$$
\text { 3?. }
$$

coral bottom, Jan, 22, 1885; "Albatross" sta. 2345.

RAIGE: Known only from type.

MEASUEMEITS (mm.): Shield, length 6.6 , width 7.8 , carapace 9.5 , eyes 5.0 , chela, length 9.2 , w1dth 3.4 , thickness 4.4 , dactyl 3.2 .

\section{Cancellus tanneri Faxon}

Cancellus tanneri Faxon, 1893, p. 167. --Gordan, 1956, p. 306 .

MATIRIAL EXAYIMED; Type and one other spec1men.

Holotype male, a small spec1men $18 \mathrm{~mm}$. long, at $\mathrm{MCZ}$; Gulf of Panama; "Albatross".

Cuba: Off Havana, $23^{\circ} 05^{\prime} \mathrm{N}_{0}, 82^{\circ} 33^{\prime} \mathrm{W}_{.}, 260$ Ims. Mar. 23, 1939; "Atlant1s" sta. 3303; 1 female in cavity of a compact s111ceous sponge.

RATGE: Known only from these two specimens.

NEASUREVENTS $\left(\mathrm{mm}_{0}\right)$ : Sh1eld, length 7.5 , width 7.8 , carapace 8.7 , eyes 5.0 , chela, length 8.4 , width 3.2 , thickness 4.3 , dactyl 3.5 .

REMARKS: Th1s 1s the f1rst record of th1s species from the Atlantie and apparently only the second specimen taken. The type differs from the Cuban specimen only in the presence of a deep puncta behind each depression in the frontal margin. Compar1son with a type specimen of $\mathrm{C}$. parfait Milne Edwards and Bouvier at the MCZ indicates a close relationship between these two, perfalt1 differing 


\section{8.}

mainly in the presence of a rounded protuberance on the base of each uropod.

\section{Genus Clibanarius Dana}

Shield squarish, longer than broad, frontal project. Ions subequal. Cardiac plate narrowed posteriorly, broadest about a third of distance from anterior end. Eyes slender, elongate but shorter than shield. Eye scales usually closely spaced; widely so in C. anomalus. An. tennular peduncles from three-fourths to one and one. fourth times as long as eyes. Antennal peduncles usually shorter than eyes, occasionally equal, acleles dentate or spinous; Plagella nude, never exceeding pereiopods.

Chelipeds usually equal, chela articulating ho. rizontally with carpus. Fingers spooned, tips hoof-shaped and darkly corneous. Walking legs strong, usually com_ pressed laterally. Rasp of fourth perelopods ovold, larger than that of I1fth pereiopods, Pourth pair subchelate, fifth chelate.

Unpaired pleopods four in both sexes. Telson sub. symmetrical, 11ttle indented at midine.

G111 palrs 13, lamellae phyllobranchiate.

\section{Key to Species}

1. Eye scales widely spaced; a deep_water form.....anomalus. Eye scales approximated; 11ttoral forms..............2. 
2. Dactyl of walking legs longer than propodus............ Dactyl of walking legs shorter than propodus..........4.

3. Propodus of walking legs with four narrow stripes of white separated by broad dark stripes. Bye scales minutely spined at tips. Antennular peduncles exceeding eyss...........................vittatus.

Propodus of walking legs with a dorsal, a lateral, and a ventral stripe of dark color of same width as inter. vening light stripes. Eye scales tipped with three calcareous spinules. Antennular peduncles not more than equaling eyes...................... sclopetarius.

4. Propodus of walking legs with a broad, 11 ght stripe bordered by dark green above and below. Eyes minutely swollen at cornea, stalks as thick at mld-section as at cornea............................. brasilifensis.

Color of legs and body mainly blue. Walking legs banded rather than striped. Eyes somewhat bulbous at cornea, stalks most slender in mid-section.....tricolor.

Clibanarlus anomalus Milne Edwards and Bouvier

Clibanarius anomalus Milne Edwards and Bouvier, 1893, p. 157, p1. 11, 11gs. 13-23. --Gordan, 1956, p. 307.

MATERIAL EXAMINED, Type and one other specimen. Holotype Iemale; Barbados; 100 Ims.; "Hassler.",

Caribbean sea: West of Rosalind Bank; $16^{\circ} 35^{\prime} \%, 80^{\circ}$ $55^{\prime} W_{.}, 100$ fms.; Aug. 24, 1957; 1 male.

RANGE: Caribbean Sea, western and southeastern parts 63 to 173 fms.

DIAGNOSIS: Perelopods short, dactyl of walking legs nearly equaling propodus. Outer surfaces of walking legs abunđantly punctate. G11l covers form calcifled plates anteriorly. 


$$
40 .
$$

DESCRIFTION: Shield flat, subquadrate, heavily calc1fled; surface shallow punctate. Fostrum blunt, exceed. ing lateral teeth. Cardiac plate broadest near midpolnt, narrowed posteriorly. Glll covers form calcified plates on anterior three-fleths.

Eyes narrow, little swollen at elther end; stalks with an uncalcifled line along outer surface. Eye scales small, w1th short tips. Antennular peduncle short, falling to reach cornea of eye. Antennal peduncle also short; base with a short, outer protuberance bearing fine denticles and setae. Second segment with inner angle rounded, outer not produced but with a lew denticles. Acicle short, barely reaching terminal segment of peduncle; feebly armed. Flagellum nude, exceeding chelipeds, composed of very short articles.

Chelipeds subequal, merus armed on distodorsal margin. Carpus and propodus armed with large denticles dorsally. Fingers spooned, gaping except at black, hoof_shaped tips. Walking legs short, strong; merus of first pair armed with numerous denticles on ventral angle. Carpus and propodus of both pairs armed with rounded denticles dorsally; dactyl. with a line of corneous spinules on ventral angle; corneous claws stout. Outer surfaces marked by 1rregular rows of numerous punctae.

Fourth perelopods short, heavy; propodal rasp large, covering about three-fifths of surface. Dactyl short, with 
a curving row of fine scales. Hand of fifth pair narrow, pointed distally, with a rasp on outer distal half. Sternal projection between third pair of coxae broad, heavy, setose on anterior margin. Coxal openings of fifth pair medial to ventral callosities. Tergal plates of ab. domen cover most of dorsal surface. Telson asymmetrical; left terminal lobe larger; margins unarmed, setose. COZOR: Specimen from "Oregon" sta. 1890 in alcohol six months. Shield and head appendages white. Walking legs Indian orange distally; forming stripes which enclose rows of punctae more proximally. Chelipeds missing. MEASUREMENTS (mm.): Shield, length 6.0, width 5.2; carapace 10.0 ; eyes 4.5 ; third perelopod, basis-1schium 2.3, merus 5.3, carpus 4.0, propodus 5.1, dactyl 5.5 .

\section{Clibanar1us bresiliensis Dana}

Clibanarius brasiliensis Dana, 1852, p. 467, p1. 29, 11g. 7. --Gordan, 1956, p. 308.

Clibanarius antiliensis stimpson, 1859, p. 235. -_Gordan, 1956, p. 307. -_?Chace, p. 152.

Clibanarius brachyors Bouvier, 1918, p. 9. --Gordan, 1956, p. 308 .

MATERIAL EXAMINED 2 One hundred and forty_one specimens from Florida and Puerto Rico.

Florlda: Palm Beach Inlet; July 7, 1957; R. Christensen; 1 ovig. female, carapace length $4.2 \mathrm{~mm}$. South Lake 


$$
42 .
$$

Worth Inlet; Aug. 25, 1957; R. Christensen; 3 lemales (2 ov1g.). Key West; July, 1957; E. L. Plerce; 1 male.

Puerto Rice: Maguez Id., Mayaguez; Jan., 1959;

J. R. Lopez; 88 males, 48 females (32 ovig., 2 with a parasitic 1sopod under the g111 cover).

RANGE; Palm Beach, Fla., to Brazil.

DIAGNOSIS: Shield abundantly punctate. Eye scales squarish, with four or five spinules distally, the inner two subequal. Eyes thick and short in small specimens. DESCRIPTION: Shield sparsely setose laterally; punctae most evident on gastric region. Rostrum blunt trlangular, exceeding lateral teeth. Byes slender, cornea little swollen; stalks slightly curved out. Eye scales approximated, squarish; with flve minute spinules interspersed with one or two setae on distal margin. Antennular peduncles exceeding eyes by a fourth of terminal segment; those of antennae reaching cornea. Second segment with spinous denticle on outer angle; acicle with three, in. cluding two at tip. Flagellum stout, nude, shorter than perelopods.

Merus of chellped with two spines on outer distoventral angle. Carpus with a spine on inner distal angle, two smaller ones behind 1t. Faces of chelae armed with many strong denticles with corneous tips. Walking legs strong, short, equaling chelae. Dactyl shorter than propodus with seven corneous spinules on 
ventral edge; setae sparse; claws very dark and strong. Fourth perelopods with a distodorsal calcareous spinule on carpus. Telson subsymmetrical with an even fringe of setae.

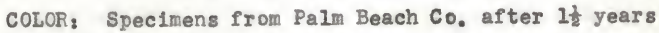
in formalin. Carapace hazy blue posterlorly. Shleld dark greenish brown with white punctae. Chela brown with white dots and denticles. Walking legs olive green dorsally and ventrally with broad white stripes on sides except on dactyl. Latter with proximodorsal stripe of brown, remainder white.

MEASUFEMENTS (mm.): Male Irom Key West. Shleld, length 6.0 , width 4.1 ; carapace 10.0 ; eyes 4.2 ; chela, length 6.4 , width 2.6 , dacty 3.6 , third right perelopod, basis_1sch1um 2.6, merus 4.6 , carpus 3.5 , propodus 5.4 , dacty1 4.6 .

\section{Cl1banarius sclopetarius (Herbst)}

Cancer sclopetarius Herbst, 1791, p. 23, pl. 23, 11g. 3. Pagurus sclopetarlus Bose, 1802.

Pagurus tuberenlosus H. Milne Edwards, 1848, p. 278.

Pagurus cubensis Saussure, 1858, p. 39. _-Gordan, 1956, p. 308 .

Clibanarius cubensis Rathbun, 1900, p. 144. Clibanarius sclonetarius St1mpson, 1859, p. 85. --Gordan, 1956, p. 310. 


\section{4.}

C11banarius tuberculosus Stimpson, 1858, p. 234.

Clibanarius carnescens M1ers, 1877, p. 658, p1. 66, f1g. 2.

Clibanarius formosus Ives, 1891, p. 182, pl. 5, 11gs. 1,2.

Clibanarius hebes Verr111, 1908, p. 450, 11gs. 65.66. MATERIAL EXAMINED: Two specimens from Florida. Palm Beach Co., South Lake Worth Inlet, Aug. 25, 1957; R. Christen. sen; 1 male. Key West; July, 1957; E. L. P1erce; 1 female. FANGE, Palm Beach Co., Fla, to Braz1l.

DIAGNOSIS: Dark and 11ght stripes of walking legs nearly equal in width. Many small punctae on gastrle region of shield. Eye scales with three calcareous spinules at tip. Acicle with five spinules, incluaing one at tip.

DESCRIFTION: Shield uneven, sparsely setose; numerous punctae medially. Margin ralsed botween lateral teeth. Eyes little shorter than shield, narrowed medially, curving outward distally. Eye scales approximated distally; three terminal spinules. Antennular peduncle reaching cornea; that of antenna a little shorter. Second segment with a spinule on outer angle, a minute denticle at inner. Acicle with three spinules on inner margin, one on outer margin Just behind tip.

Merus of chellpeds with a spinule on outer distoventral angle, six denticles on inner ventral angle. Carpus with a stout spine at inner distodorsal angle. Chela presents 


$$
45 .
$$

several strong denticles, those on dactyl with corneous tips. Setae sparse but strong on dorsal surfaces.

Walking legs with a short spine just below outer distal angle of merus, a stronger one at distodorsal angle of carpus. Dactyl rather sparsely setose; a distoventral row of fine, corneous scales behind strong claw. Fourth pere. lopods with a distodorsal calcareous spinule on carpus. Friction pads numerous on ventral surfaces of perelopods. Telson short; three small spinules on distal left side.

COLOR: Specimen in formalin $1 \frac{1}{2}$ years. A pattern of burnt sienna and orange rufous stripes on walking legs; darker stripes slightly broader at most points. Shleld and posterior part of carapace giving rise to fine setae.

MEASUREMENTS (m.): Male from Palm Beach Co. Shield, length 5.5 , width 4.7 ; carapace 11.0 , eyes 5.0 ; chela, length 5.2, width 2.3, dactyl 3.0, third right perelopod, basis_ischium 2.9, merus 4.7 , carpus 3.6 , propodus 6.8 , dactyl 7.4 .

\section{Clibanarius tricolor (Gibbes)}

Pagurus tricolor G1bbes, 1850, p. 189.

Clibanarius bicolor St1mpson, (lapsus calam1), 1859, p. 39 .

Clibanarius tricolor Stimpson, 1858, p. 234. --Gordan, 1956, p. 310.

Clibenarius tricolor Heilprin, 1888, p. 321; erroneous 
spolling of Clibanarius Dana.

MATERIAL EXAMINED: South Lake Worth Inlet; Aug. 25, 1957; R. Christensen; 12 males, 10 females (1 with ovaries f11led with eggs).

RANGE: Palm Beach Co., Fla., and Tortugas Ids, to Puerto Rico.

DIAGNOSIS: Merus, carpus, and propodus of walking legs with deep punctae on outer and dorsal surfaces. Legs banded rather than striped.

DESCRIPTION: This species is very difficult to dis. tinguish from $\mathrm{C}$. antillensis in alcohollc specimens. The strikingly different color pattern distingulshes fresh material. The following remarks apply to the present species and will ald in separation of the two specles.

Shield less punctate. Eyes tending to be a littlo more dilated at the cornea and more outwardly curved; stalks more slender in midsection. Eye scales usually slightly separated with the inner spinule strongest, the rest evenly decreasing in size.

Denticles of chelae tending to be a little more numerous and stronger.

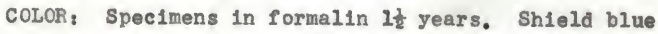
gray anter1orly, faded blue poster1orly. Posterlor part of carapace suffused 11ghtly with dark blue. Eyestalks blue, cornea brown, eye scales raded blue with red bases. Chellpeds dark brown with white patches and denticles. 


$$
47 .
$$

Merus, carpus and propodus pale blue, dark blue distally. Punctae reddish brown. Bases of last three segments reddish orange. Dactyl white with minute red punctae. MEASURENENTS (mm.): Male from South Lake Worth. Shleld, length 3.0 , width 2.3; carapace 5.3; left eye 2.3; chela, length 2.1, width 1.0, dacty1 1.1; third right pere. lopod, basis-1schium 1.3, merus 2.4, carpus 1.8, propodus 2.9 , dacty 2.5 .

\section{Clibanarius vittatus (Bosc)}

Pagurus vittatus Bosc, 1802, p. 78, pl. 12, f1g.1.

Pagurus symmetricus Randa11, 1839, p. 133.

C11banarius symmetrieus Stimpson, 1859, p. 235.

Cl1banar1us vittatus Stimpson, 1859, p. 235. -.Behre, 1950, p. 22. Wass, 1955, p. 148. --Gordan, 1956, p. 311. -H1ldebrand, 1958, p. 159.

Clibanarius sneciosus M1ers, 1877, p. 658, p1. 66, f1g. 3.

PClibinarius lord Miers, 1877, p. 659.

Clibinarins vittatus Fedgepeth, 1950, p. 78, 1950 b, p. 114; erroneous spelling of Clibanarius Dana.

MATERIAL EXAMINED: Seventy-three specimens from Florida, Texas and Mexico.

Mexico: Vera Cruz, Estero Grande Cabo Rojo; Apr. 27, 1955; H. H. H1ldebrand; 1 trale. 
Texas: Matagorda Bay, Palacios Reef; Dec. 20, 1904, T. E. B. Pope; 1 male.

Florida: Palm Beach Co., South Lake Worth Inlet; Aug. 25, 1957; R. Christensen; 27 males, 33 females (12 ovig.). Franklin Co., $8 \mathrm{mi}$. west of Apalachicola; May 28, 1957; R. Christensen; 9 males. Tortugas, southern end of Bush Key; July 14, 1932; W. L. Schmitt; 1 male. Key West; July, 1957; E. I. Plerce, 1 female.

RANGE: North Carolina to Brazil, apparently not found In most of Car1bbean Ids.

DIAGNOSIS: Dark str1pes on walking legs much wider than 11ght stripes. Eye scales minutely spined at tips. Antennal peduncle feebly armed with a spinule on outer projection of second segment and minute spinules at base and tip of acicle.

DESCRIPTION: Shield squarish, gastric region lacking punctae, minute rostrum not reaching base of eye scales. Eyes slender, subequal to shield; dorsal stripe bordered by minute setae. Antennular peduncle equaling eyes, that of antennae not reaching cornea. Flagellum nude, equaling perelopods.

Merus of chelipeds with a calcareous spine on outer distoventral angle, denticles on inner ventral angle. Carp1 with a strong spine on inner distodorsal angle. Chelae covered with numerous calcareous denticles, largest medially. 
Walking legs strong; rows of short, stiff setae on darker stripes. Carpus armed with a short distodorsal spine. Telson short, lacking a median cleft, margin with fine teeth.

COLOR, Pattern of specimens preserved in formalin. Propodus and dactyl of walking legs distinctively marised with three narrow white stripes on each s1de; background brown.

MEASUREMENTS (mm.): Female from Key West. Shleld, length 12.0, width 10.0 ; carapace 23.5 ; eyes 11.0 ; chela, length 15.0, width 7.2, dactyl 9.5; third right pereiopod, bas1s-1sch1um 6.2, merus 10.0, carpus 8.4, propodus 11.5, dacty1 17.?.

\section{Genus Dardanus Paulson}

Shleld at least as long as broad, with median, un. calcifled furrow steming from cervical groove and branch. Ing to form a goblet_shaped outline. Lateral teeth promi. nent, blunt. Rostrum absent. Cardlac plate narrow; widest, and with a pair of marginal indentations, anterioriy.

Eyes stout, swollen at cornea, relatively shorter in adults than in young; with a tuft of strong setae at dorsal apex of stalk. Eye scales truncate, with four or more spines on distal margin, tips pointing inward. Antennular peduncle at least equaling eyes. Antennal peduncle equal- 
ing or slightly exceeding eyes, acicle never exceeding; flagellum nude, equaling perelopods. Maxillipeds with exopods flagellate; flagellum of first Peeble.

Chel1peds unequal, left member largest; finger tips dark, corneous, meeting rather than erossing. Proximal parts of cutting edges composed of strong, calcareous teeth; corneous tips sharp-edged. Walking legs equaling chelipeds; propodus and dactyl of second on left orna. mented with transverse stridulating ridges. Corneous tips small, sharp. Chelae articulating obliquely with carpi. Fourth perelopods subchelate. Propodal rasp convex, longovoid, occupying most of lower half of outer surface. Dactyl overreaching propodus, with a row of spinules behind curved tip. Fifth perelopods chelate, slender, long and with a rasp covering distal three.fifths of outer surface. Sternum between third perelopods presents a round stalk with a tuft of setae at the tip. Male pleopods four in number, small, with outer ramus only a pap1lla. $\Delta b_{-}$ dominal terga narrow, uncalcifled. Fleshy lobe with long1tudinal crest of setae located ventral and slightly posterior to third pleopod. Telson feebly armed, asymmetrical. G11ls phyllobranchlate, numbering 14 pairs.

\section{Key to Species}

1. Major cheliped not much larger than minor. Chelae with transverse ridges armed with spinules...... peters1. 
Major cheliped much larger than minor. Chelae with scalloped, plate-like tubercles lacking spines........2.

2. Outer surface on propodus of third left perelopod with stout teeth on transverse ridges above lateral groove................................ Pecundus.

Transverse ridges scalloped on propodus of third left pereiopod. renosus.

Dardanus lecundus $\mathrm{n}, \mathrm{sp}$.

MATERIAL EXAMINED: Holotype female; off St. Augustine, Fla.; $30^{\circ} 24^{\prime} \mathbb{N}_{.,} 80^{\circ} 20^{\prime} \mathrm{W}_{.3} 24 \mathrm{fms}$; June 3, 1957; "Combat" sta. 353 ; in shell of Fasciolaria tulina Linnaeus.

RANGE: Known only from type.

DIAGNOSIS: Large species, body of type about $15 \mathrm{~cm}$. long. Left chela much larger than right. Surface of major chela armed with strong, conical teeth fringed by fine setae. Armament of propodus and dactyl of third left perelopod similar to that of major chela, with blunt denticles in rows.

DESCRIPTION: This species is closely related to $\mathrm{D}$. venosus, differing mainly in the chelipeds, the stridulating surfaces of the third left pereiopod and the color. Only the characters which differ from R. venosus are discussed in the following description.

Eyes strong, little swollen at cornea. Apleal tuft of setae on eyestalk narrow. Antennular peduncle exceeds eyes by two-thirds of terminal segment.

Left cheliped 2.8 times as heavy by weight as right. 


\section{2.}

Spines on inner ventral margin of merus sma1l, calcareous. Dorsal surface of carpus similar to that of $D_{\text {. Venosus }}$ with spines proportionately stronger. Dorsalmost spines of propodus strong, becoming rounded teeth distally. Ventral margin presents row of short, strong denticles with corneous tips. Denticles on face of hand strong, occurring singly, or less often, as two or three united. Circular fringe of fine plumose setae surrounds each anteriorly. Teeth appear worn or broken at tips. Cutting edges of fingers with six teeth on dactyl (last two un1ted), nine on pollex. Minor cheliped with numerous bristles on exposed surfaces. Dorsal. most parts of carpus and propodus armed with several strong spines.

Ornamentation of third left perelopod similar to that of $\mathrm{D}$. zenosus but with stout teeth on transverse ridges above lateral grooves. Propodal groove with short row of single teeth. Broad tubercles of lateral ridge with six worn, caleareous points proximally on propodus, diminishing to one or two on dactyl. Fringes of transverse ridges composed of stronger but less dense setae than in $D_{\text {. Venosus. }}$ Dorsal and ventral fringes with a tuft of strong bristles at each transverse furrow. Bristles accompanied by row of stout teeth with corneous tips. Remaining perelopods less setose except distodorsally on dactyls. I1ps of dactyls stout, corneous.

Sternal projection between coxae of third perelopods 
directed anteriorly; shape more conical than cylindrical w1th a spinule surrounded by setae at t1p. Fleshy abdominal flap near third pleopod elongate and setose. Telson produced on left side, feebly armed.

COLOR, Ground color of shield, eyestalks and eye scales salmon to flesh. Bands of deeper color appear on eyestalks and at each end. Peduncles of antennules and antennae with longitudinal stripes of Saturn red; same color appears in lateral stripes on antennal plagellum. Ground color on merus and carpus of left chela vi. naceous buff to flesh; venations on outer distolateral areas scarlet. Ground color of palmar face buff yellow; conlcal teeth rose purple to flesh with proximal teeth white, those on fingers cream buff. Setose fringes of teeth flame scarlet proximally to scarlet vermillion on fingers. Scarlet venations form network on most of light colored ventral surface. Short tufts of crimson bristles appear near ringertips.

Outer surface of minor cheliped with variegated col oring; orange buff proximally on merus to flesh distally and on carpus. Ground color on face of chela wh1te except for salmon to coral band midway. Venations range from Saturn red proximally to carmine at Pingertips, while bristles range from buff yellow on merus, through many banded with coral, crimson and yellow, to those in solld crimson tufts at fingertips. 


$$
54 .
$$

Ground color on ornamented surface of merus of third left perelopod mainly chrome orange with teeth in ridges rose pink to almost white; setose fringes scarlet. Bristles of crests crimson with light yellow tips. Most teeth out. ined by scarlet veining. Dactylar color similar but darker.

MEASUREMENTS (ma.): Shleld, length 17, width 15.5; carapace 32.5 ; eyes 10 ; left chela, length 26 , width 16 , dactyl 14.5; right chela, length 20, width 10, dactyl 11.5; third left pereiopod, basis-1sch1um 7.5, merus 15, carpus 13, propodus 14.5 , dacty 26.

REMARKS: The type female is estimated to be carrying 150,000 eyed eggs, each about $0.5 \mathrm{~mm}$. In diameter. This colorful species and the other two members of the genus in the western Atlantic probably prefer shell, sand, or coral bottoms.

Dardanus peters1 (A. Milne Edwards) n. comb.

Aniculus netersi1 A. Milne Edwards, 1880, p. 40.

Pagurus striatus var. petersi1 A. Milne Edwards and Bouv1er, 1893, p. 162, pl. 11, f1gs. 24-35.

Pagurus arrosor var. netersi Moreira, 1903, p. 64, 1905, p. 132.

Pagurus arrosor Alcock, 1905, p. 168.

Dardanus arrosor var. peters1 Gordan, 1956, p. 312. 


\section{5.}

Dardanus insignis Springer and Bullis, 1956, p. 16. Not Dardanus Insignis Saussure, 1858, p. 453, p1. 3, P1g. 20. MATERIAL EXAMINED: Sixty-two specimens from six gener. al areas. The type specimen was not located. However, the large male, MCZ 12778, described by Milne Edwards and Bouvier (1893) was found.

Atlantic Coast: East of Cape Hatteras; $35^{\circ} 05^{\prime} \mathrm{N}$. , $75^{\circ} 09^{\prime} W_{0}, 100$ fms.3 June 16, 1957; "Combat" sta, 370, 1 male. East of Cape Lookout, $34^{\circ} 54^{\prime}$ N., $75^{\circ} 25^{\prime}$ W.; 75 fms., June 17, 1957, "Combat" sta. 384, 1 male in a Murex shell. $34^{\circ} 46^{\prime} \mathrm{N} ., 75^{\circ} 37^{\prime}$ W. 50 Pms.; June 17, 1957; "Combat" sta. 385; 1 in a Phallum shell. off Georg1a; $31^{\circ}$ $29^{\prime} \mathrm{N} ., 79^{\circ} 33^{\prime} W_{0} ; 60$ Ims.; October 3, 1957, "Combat" sta. 512 ; 1 in a Phalium shell. Off St. Augustine, $29^{\circ} 27^{\prime} \mathbb{N}$. , $80^{\circ} 20^{\prime}$ W.; $^{3}$ fms.3 June 3, 1957; "Combat" sta. 350, 1 disintegrated speciren, off Cape Canaveral, $28^{\circ} 33^{\prime} \mathrm{N} .$, $80^{\circ} 05^{\prime} W_{.3} 35$ fms.3 Jan. 18, 1940, "Pellcan" sta. 170-2, 1 female, Off Fort Plerce; $27^{\circ} 29^{\prime}$ No, $78^{\circ} 58^{\prime} \mathrm{W}_{0} ; 200 \mathrm{fms}, 3$ Feb. 27, 1957; "Combat" sta, 236; 1 juv, male. Stralts of Florida; $25^{\circ} 13^{\prime}$ N., $80^{\circ} 10^{\prime}$ W.; 40.50 fms.; July 26, 1957, "Combat" sta. 455,1 male. Santaren Channel, $24^{\circ} 04^{\prime} \mathrm{N}$. , $79^{\circ} 15^{\prime}$ W.3 $^{2} 250$ fms.; July 24, 1957; "Combat" sta, 448, I male.

Gulf of Mexice: Off Mississippi Delta, $29^{\circ} 02^{\prime} \mathrm{N}$. , $88^{\circ} 50^{\prime} W_{.3} 89$ fms.; Feb. 4, 1938, "Pelican" sta. 10, 1 female. Western Florlda $329^{\circ} 47^{\prime} \mathrm{N} ., 86^{\circ} 51^{\prime} \mathrm{W}_{0} ; 96 \mathrm{fms}, 3$ 


\section{6.}

Mar. 5, 1939; "Pellcan" sta. 144-2, 1 ovig. Semale. $29^{\circ}$ $16^{\prime} \mathrm{N} ., 85^{\circ} 32^{\prime} W_{0} ; 26$ fms.3 Feb. 7, 1885; "Albatross" sta. 2369; 2 Juveniles.

Tortugas and Florida Kers: Specimens collected by W. L. Schmitt unless otherwlse noted. South of Tortugas: 60 Ims.; June 30, 1932; I in a Phalium shell; I Pemale. $55-58$ fms.; July 28, 1932; 1 male. 39 fms.; June 26, 1932; 1 ov1g. Pemale. 40 fms.3 June 17, 1932, 1 female. 1931; Paul Bartsch, 8 males, 4 ovig. females (carapace length of females 16_-22 mm., of males $10-67 \mathrm{~mm}$.). $40.45 \mathrm{fms}$.; Aug. 20, 1931; Paul Bartsch; 2 males; 2 Pemales ( 1 ov1g.). June 17, 1932; 2 ovig. Semales, 40 Pms.; Aug. 4, 1931; 1 male, 1 female. 60 fms., July 22, 1931, 3 males, 3 females, 1 In shell. 35 Ims.; Aug. 14, 1933; H. H. Darby; 1 Juv. 45 fms.; June 10, 1925; I in a phallum shell. 60 fms.; July 22, 1931, 1 male, 1 in shell of Xiphosura. 40 fms.; Aug. 4, 1931; 1 in Murex shell covered by sponge. $80 \mathrm{fms.;}$ July 13, 1930; 1 in shell of Strombus, 1 male in shell of Buszeon. Off Mlam1 and Keys: M1am1; 30 fms.3 May, 1912; J. B. Henderson; 2 Juv. Pemales. Key West; 65 fms.; J. B. Henderson; 1 male. $24^{\circ} 26^{\prime} \mathrm{N} ., 81^{\circ} 48 \mathrm{l}^{\prime} \mathrm{W}_{0} 337 \mathrm{Pms.3}$ Jan. 15,1885 ; "Albatross" sta. 2317; 1 male in bryozoan Hipnoporidra edax Busk.

Campeche Bank: $23^{\circ} 20^{\prime} \mathrm{N} ., 89^{\circ} 16^{\prime} \mathrm{W}, 384 \mathrm{fms} . ;$ Feb. 18, 1877; "Blake" sta. 36, I large male, MCz 12778. off Surinam: $07^{\circ} 38^{\prime} \mathrm{N}$, , $54^{\circ} 111^{\prime} \mathrm{W}_{0} ; 75$ Pms.; Nov, 8 , 


\section{7.}

1957; "Oregon" sta. 2015, 1 male, $07^{\circ} 30^{\prime} \mathrm{N} ., 54^{\circ} 16^{\prime} \mathrm{W} . ;$ 125 fms.; Nov. 8, 1957; "Oregon" sta. 2013; 1 male. 07 18' N., $53^{\circ} 32^{\prime}$ W.; 100 Pms.3 Nov. 8, 1957; "Oregon" sta. 2021, 2 males.

off Northern Braz12: $04^{\circ} 05^{\prime} \mathrm{N} ., 50^{\circ} 27^{\prime} \mathrm{W} . ; 50 \mathrm{fms} .3$ Nov. 13, 1957; "Oregon" sta. 2051; 1 male.

RANGE; Cape Hatteras, N.C., to Braz11; 26 to 250 fms. In the Caribbean reported only from Barbados.

DIAGNOSIS: Large, colorful specles. Perelopods w1th overlapping transverse ridges armed with spinules and Pringed with setae. Chelae not markedly unequal.

DESCRIPTION\& Carapace flattened. Lateral teeth rounded. Apical tuft of setae on each eyestalk small, dense. Eye scales separated at bases, occasionally approximated at tips. Antennular peduncle exceeding eyes by as much as half of terminal segment in adults. Antennal peduncle exceeding eyes only in adults. Aclele short, equaling eyes In large adults, scarcely reaching cornea in smaller spect. mens; feebly armed with several denticles.

Left cheliped armed with strong calcareous spines on Inner ventral angle of merus, with sharp, corneous-tipped spines on dorsalmost areas of merus, carpus and chela. Face of carpus and chela covered with narrow, overlapping plates. Latter with corneous spinules and even fringes of fine setae along all margins. Fingers present tufts of strong setae. Right cheliped similar to left, not markediy 
smaller.

Propodus and dactyl of third perelopod on left larger than in right member; outer surfaces with transverse ridges resembling those of chelae. Dorsal margin of dactyl with a row of spinules and numerous strong setae. COLOR, Specimen from "Combat" sta. 455 after one year in formalin. Scarlet occurs as a narrow line at bases of eye scales and in three bands around each ejestalk. Latter with apleal tuft of erimson setae. Shingle-like ridges of chelae geranium red interspersed with yellow vermiculations proximally, solld and more intense distally. Setae in fine Iringe along each scale change from yellow at base, then red, to white at tips. Corneous spinules of ridges light yellow. Walking legs similarly ornamented and colored. Large specimens from Dry Tortugas darker in color. MEASUREMENTS (mm.): Large male taken off Surinam. Shlela, length 22, wiath 20.5; carapace 43; eyes 12; left chela, length 39, w1dth 22, dacty1 21.5; left chela 34.5; third left perelopod, basis-ischlum 12, merus 23, carpus 19.5, propodus 22.5, dacty1 44 .

\section{Dardanus yenosus (H. Milne Edwards)}

Pagurus venosus H. M11ne Edwards, 1848, p. 61. Pagurus 1nsignis Saussure, 1858, p. 453, p1. 3, f1g. 20. --Martens, 1872, p. 119. --Alcock, 1905, p. 170. Bouvier, 1918 , p. 6. 
Petrochirus insignis Rathbun, 1900, p. 144.

Pagurias Insignis Benedict, 1900, p. 141.

Dardanus 1ns1gn1s Gordan, 1956, p. 314.

Dardanus venogus Verr111, 1908, p. 452. --Gordan, 1956, p. 316.

MATERIAL EXAMINED: Twenty-two specimens from seven localities.

ore South Carollng: $32^{\circ} 51^{\prime} \mathrm{N},, 78^{\circ} 59^{\prime}$ W., 14 Ims.; Feb. 12, 1940; "Pelican" sta. 182-23; 1 in shell. ope Georgia: $31^{\circ} 28^{\prime} \mathrm{N} ., 79^{\circ} 46 \mathrm{l}^{\prime}$ W.; 25 fms.; Feb. 1, 1940, "Pellcan" sta. 179-4, I fewale in a phallum shell. osf st. Augustine: $30^{\circ} 24^{\prime} \mathrm{N} ., 80^{\circ} 20^{\prime} \mathrm{W}_{* 3} \mathrm{fms}$.; June 3, 1957, "Combat" sta. 353; 1 ovig. Pemale in P017nices shell.

Tortugas: Fort Jefferson; June 25, 1925; W. L. Schmitt; 1 male. Fort Jefferson moat; Aug. 11, 1924; W. L. Schmitt; I male from f1sh trap set in eel grass. Aug. 11, 1930; W. L. Schmitt; 1 in Strombus shell.

Ealt1: Muertas Is.; Feb., 1929; Poole and Perrygo, 1 male.

Brit1sh Guians: $07^{\circ} 55^{\prime} \mathrm{N}$., $57^{\circ} 30^{\prime}$ W.; 45 Ims.; Nov, 5, 1957; "Oregon" sta. 2000; 1 in sponge.

Northern Braz11: $04^{\circ} 02^{\prime} \mathrm{N} ., 50^{\circ} 33^{\prime}$ W.; 38 Ims.; Nov. 13, 1957, "Oregon" sta, 2049; 1 male, 3 females. 04" $04{ }^{\prime}$ N., $50^{\circ} 32$ ' W.; 40 fms.; Nov. 13, 1957; "Oregon" sta. 2050; 3 females from Natica shells, 2 males and 2 females 
(1 ov1g.) from rusinus shells, $04^{\circ} 05^{\prime} \mathrm{N} ., 50^{\circ} 27^{\prime} \mathrm{W}_{0}, 50$ fms.; Nov. 13, 1957, "Oregon" sta. 2051, 2 males. $02^{\circ} 31^{\prime}$ N., 48 48' W.; 55-60 fms.; Nov. 15, 1957; I large male in Fasciolar1a shell.

RANGE: Bermuda and South Carolina south to mouth of Amazon River; littoral to 55 fms.

DIAGNOSIS: Colorful species not attaining as large a size as D. peters1. Major cheliped much larger than minor. Chela faced with oval, scalloped, plate-like tubercles lacking spines. Propodus and dactyl of third left pereiopod with a broad, deep groove dorsal to a prominent outer ridge.

DESCRIFTION, Apleal tuft of setae on eyestalk rising from a transverse line and forming a median comb over the cornea. Antennular peduncle equaling eyes in young, considerably exceeding in adults; length of antennal peduncle in relation to eyes also varying with age, usually subequal.

Left cheliped four times as heavy as right by welght. Basis-ischium and merus with rounded, calcareous spines on inner ventral margin. Merus with two sharp spines on disto. dorsal margin. Carpus with five sharp spines on inner dorsal margin, others more laterally. Face of chela covered with tubercles which present one to six raised points distally; points appear translucent at tips. Tubercles with more than one point appear scalloped. Fan of plumose setae borders each tuberele distally. Cutting edges with $s 1 x$ 


\section{1.}

calcareous teeth on dactyl, elght on pollex.

Right cheliped small, chela lacking scalloped tubercles. Carpus, propodus, and dactyl with short, stout spines on dorsalmost surface. Scattered setae long, bristle_like.

Propodus and dactyl of third right perelopod with strong outer ridge sltuated more ventrally on dactyl than on propodus. Deep groove seen above this ridge. Dorsal and ventral margins appear crested. Transverse ridges on propodus and plates on dactyl scalloped as on tubercles of major chela, ornamentation absent in grooves except for central row of minute tubercles. Other walking legs armed with spinules on dorsal angles of dactyl, latter also presents a fine groove on outer surface.

Protuberance between third pair of coxae a narrow spike capped by a tuft of setae, as in R. Deters1. COLOR: Specimen from "Combat" sta. 353, in formalin for one year. Shield rose purple with median erimson spot behind tuft of setae on gastric region. Eyestalks with distodorsal crimson area behind apleal tuft fading to rose purple proximally and on scales. Longltudinal stripes of antennular and antennal peduncles and flagellum of latter orange_buff.

Scalloped tubercles of right chela campanula blue with fringes of buff-yellow setae. Crimson lines appear on larger tubercles, between teeth of cutting edges and as a network on white ventral part of fingers. Minor chela with 
slightly raised areas and some splnes campanula blue on palm, fading to white on fingers; each area outlined by scarlet lines and supporting one or more carmine bristles. Background on merus and carpus malnly flesh color. Transverse ridges on propodus and dactyl of third left perelopod also campanula blue with a few crimson lines; setose fringes salmon. Dorsal and ventral crests with numerous carmine bristles and dense pllose setae. All walking legs with a crimson band midway around each merus and carpus; background vinaceous.

MEASUREMENTS (mm.): Male from "Oregon" sta. 2051. Shield, length 12.3 , width 11.0 carapace 26.4 ; eyes 8.4 ; left chela, length 22.5, w1dth 13.9 , dactyl 12.5; right chela, length 13.5 , width 6.5 , dacty1 8.4 ; third right leg, bas1s-1sch1um 7.5 , merus 12.0 , carpus 10.0 , propodus 12.0 , dactyl 20.0.

REMARKS: The ovigerous female from "Combat" sta. 353 probably carrles at least 50,000 eggs, each about $0.3 \mathrm{~mm}$. in diameter.

Genus Isocheles St1mpson

Isocheles wurderanni stimpson

Isocheles wurdemann1 st1mpson, 1862, p. 85. -.More1ra, 1905, p. 143. --Behre, 1950, p. 22. --Wass, 1955, p. 151. -Gordan, 1956, p. 319. 
MATERIAL EXAMINED; Seven specimens from two areas.

Texas: W11l1s G. Hewatt; Offat Bayou, Galveston; Apr. 23, 1941; 3 males, 3 females.

Florida: Alligator Polnt, Franklin Co., Aug., 1952, 1 male in an 011va shell.

RANGE: Northern Gulf of Mexico (Florida, Louisiana, and Texas) to Venezuela and Sao Paulo, Braz1l (Moreira, 1905). Not known from any Car1bbean 1slands.

DIAGNOSIS; Carapace wedge_shaped, much broader poster1. orly. Eyes narrow, cornea small. Eye sceles contiguous. Chelipeds small, left slightly larger than right.

DESCRIPTION: Shleld as wide as long, covered with setose tubercles except in center of gastric region; setae long and stiff. Postcervical carapace and posterior part of g111 covers obscured by dense coat of p1lose hair. G111 covers composed anteriorly of many calcifled plates. Ros_ trum and lateral teeth of shield each marked by a denticle, not produced.

Eyes narrowed distally, cornea small, sparsely setose. Eye scales approximated medially, finely dentate on outer distal margin. Antennular peduncle exceeding eyes by a third of terminal segment. Antennal peduncle at least equaling eyes; basal segment granular on d1stal margin; second segment unarmed on inner angle, outer projection only a short tooth. Ac1cle heavy, short, feebly armed, pllose on inner margin, setose dorsally. Flagellum heavy 


\section{4.}

at base, shorter than carapace; a palr of strong setae directed distoventraliy at each articulation.

Chellpeds subequal, left slightly larger. Merus of cheliped spinulose above, p1lose on inner dorsal margin, otherw1se setose. Carpus with inner margin of calcareous spines bordered laterally by shallow trough, with remain. Ing dorsal surface bearing calcareous denticles. Hand and fingers faced with calcareous teeth which are broadest distally, spinous on inner and outer margins. Corne. ous finger tips sharper and longer than usual.

Walking legs with abundant calcareous spinules, denticles and granules, mostly well marked rows except dorsally on propodus. Fourth pereiopods chelate with rasp of minute scales covering rost of outer and marginal sur. faces of pollex. Fifth pair with long, narrow propodus bearing small rasp at base of pollex; rasp extends to finger tips as a row of scales on Inner margin of each. Under sur. faces of pirst three segments of perelopods exhibit numerous friction pads.

Pleopods of lemale with thick covering of pllose hairs to which are attached, on the lirst three pleopods, about 10,000 eggs, each about $0.3 \mathrm{~mm}$. In diameter. External ramus of male pleopods very minute. Telson asymetrical, without a median cleft, feebly armed at extremity.

MEASUREMENTS (mm.): (Male from Texas coast) Shield length 8.0 , width 8.2 , carapace 16.5 ; eyes 5.3 , left chela, 
length 13.0 , width 7.5 , dactyl 7.3 ; third right pereiopod, basism1schium 4.3 , merus 7.0 ; carpus 6.3 , propodus 10.0 , dactyl 16.0 .

\section{Genus Paguristes Dana}

Shield broadened anterlorly, more or less setose laterally and in shallow grooves. Eyes slender, usually shorter than, or equal to, anterior width of shield. Cornea dilated little or not at all. Ege scales well separated; terminating in a single spine in rost species, in up to four in a few. Peduncles of antennules and antennae varlable in length, usually well armed and setose. Antennal flagellum varying greatly in length and in amount of setae present.

Chelipeds usually equal, chela articulating obliquely w1th carpus. Walking legs usually exceeding chellpeds; dactyl longer than propodus. Fourth perelopods not chelate; narrow rasp covering most of outer ventral angle of propodus. Male with a pair of gonopods on each of first two abdominal segments, followed by three unpalred pleopods. Females with a single pair of gonopods and four unpa1red pleopods. A brood pouch composed of an abdominal flap rises immediately behind third pleopod; rudimentary in a few species. Telson usually asymmetric and armed with fine spinules.

G111 pairs 13, lamellae phyllobranchlate, usually cleft; oval in a few species. 
In striking contrast to most of the species found on the west coast of Africa, in which the females have a genital opening only on the coxa of the third left perelopod (Forest, 1954), all of the western Atlantic forms have openings on both sides in the female. While one species from the Caribbean reglon is apparentiy closely related to a Mediterranean species, the principal affinities seem to be with species from the opposite side of the continent.

\section{Key to Species}

1. Anterlor appendages presenting abundant plumose halr on head appendages and perelopods....................2. Anterlor appendages with simple setae or none.........4.

2. Shield over 1t times as long as wide. One of smallest specles in genus...................... anomalus. Shield less than $1 \frac{1}{2}$ times as long as wide..............3.

3. Chelipeds not obscured by pilose hair on carpi and chelae. A strong dorsal ridge on carpus........ hewatt1. Chellpeds obscured by fine pllose hair on dorsal surPaces. Carpus without a strong dorsal ridge...tertugae.

4. Antennal flagella with two rows of long setae forming a wide ventral angle....................... acuticornis. Flagella without above arrangement of setae..........5.

5. Antennal flagella much longer than carapace..........6. Antennal flagella but little longer than carapace....10.

6. Antennae equaling perelopods......................7. Antennae shorter than perelopods......................9.

7. Telson symmetrical; chelipeds well armed.......splnives. 
Telson asymmetrical; chellpeds armed only with dent1cles or short spines..........................

8. Dacty 1 of third right perelopod exceeding carapace. Rostrum obsolescent......................... moore1.

Dactyl of third right perelopod shorter than carapace. Rostrum present..............trlangulatus.

9. Eye scales with a single terminal spinule......... Iymani. Eye scales usually with four terminal spinules......sart.

10. Chelae nude, unarmed, with a long dorsal depression..... ................................... cadenati.

Chela not as above...............................11.

11. Chelae with scale_like covering dorsally, unarmed....... .................................. depressus.

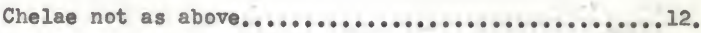

12. Body extremely flattened, deep water form....... planatus. Body less depressed, specles from lesser depths.......13.

13. Chelipeds over $1 \frac{1}{2}$ times as long as wide.......... forest1. Chelipeds less than $1 \frac{1}{2}$ times as long as wide..........14.

14. Anterolateral angles of shield equal to recessed areas in margin behind eyestalks, stalks a solld color........ ..................................... sericeus.

Anterolateral angles of shield not reaching level of postocular recessions; eyestalks spotted..............15.

15. First three perelopods with numerous corneous_tipped splnes on chelae and dactyls and a sparse amount of

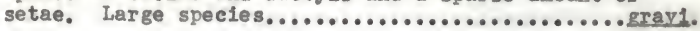

Corneous spines on perelopods less numerous; setae generally obscuring bases of spines. Medium_sized species.............................. puncticeps. 
Paguristes acuticornis n, sp.

MATERIAL EXAMINED: Holotype male; off Surinam; $06^{\circ} 48^{\prime}$

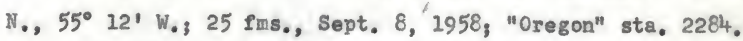
Paratype, male, found w1th type of Paguristes moore1"Benedict, but almost certainly not from same station, since moore1 was taken by the "Atlantis" only at depths between 175 and 230 Pms.; probably from Puerto Rico, Dry Tortugas; 45 fms. 1934 H. H. Darby; 1 male paratype. RANGe: Dry Tortugas to Surinam; 25 to 45 fms. DIAGNOSIS: Small specles with eyestalks narrowed distally; cornea bulbous, pointed at t1ps. Antennae short, with two rows of long hairs, as in Isocheles.

DESCRIPTION: Shield with narrow margin along entire front, lateral teeth tipped with a denticle, exceeding rostrum, Rounded elevations appear posteromediad to lateral teeth. Entire body and nearly all appendages moderately covered with Pine, pilose halrs.

Eyes equaling shield, swollen basally; cornea long, buibous. Eye scales small, with single terminal spine. Antennular peduncles exceed eyes by a third of terminal segment. Antennal peduncle equaling eyes; a minute spinule on inner angle, spine on short, outer angle. Acicle triangular, blade-11ke; one or two spinules on inner margin, tip not spined. Flagellum longer than carapace, with two 
rows of long, thin setae forming a ventral angle of about $120^{\circ}$. Segments of rlagellum long, numbering 14 or less. Chelipeds short, stout, with strong spines on inner dorsal margins of carpus and propodus. Inner ventral angle of merus armed with five denticles, outer angle with a few low denticles and a marginal spinule; spinule on distodorsal margin of merus preceded by a sharp spine projecting over separating groove. Carpus with four or 11ve spines on both inner and outer dorsal margins; a distal spine at hinge joint. Inner dorsal margin of hand with five large splnes; four rows of spinules and dentieles on dorsal surface. Long white setae rise from bases of denticles and spines. Fingers gape except at tips. Dactyl lacks corneous cutting edge; both fingers with odges of low, separated teeth. Corneous tips minute.

Dorsal surfaces of second perelopods armed with four spines on carp1, two to I1ve on propodi; third pair armed only with a small spinule on distodorsal margins of carpl. Propodus of fourth perelopods with a small triangular rasp on distal two-thirds of lower edge; dactyl without a rasp; P1fth perelopod with a rasp on d1stal two-fifths of hand. F1rst palr of gonopods narrowly separated; second pair long, with terminal segments exceeding first pair. Basal segment of left uropod unarmed. Telson asymmetric, terminal lobe on left armed with two or three spinules. 


\section{0.}

COLOR: Specimen from "Oregon" sta, 2284 after four months in formalin. Shleld mottled with orange and red; a median red spot on rostrum. Eyestalks flecked w1th red. Cornea with black pigmented center touching surface only at extreme tip. Antennular flagellum maroon below; antennal Plagellum translucent, with a narrow maroon band just behind distal ring of setae on each segment. Chelae with red veln. Ing faintly marked on proximal dorsal surface, well marked on proximal and inner ventral surface. Walking legs with proximal and distal red bands on mer1, carp1, and propod1; only a proximal band on dactyls.

MEASUREMENTS (mm.): Shield, length 2.5, width 2.5; carapace 4.5 ; eyes 2.5 , chela, length 4.0 , w1dth 1.5 , dactyl 2.5; third leg, basis-1schium 1.2, merus 2.5, carpus 1.8, propodus 3.0 , dactyl 4.2 .

\section{Paguristes anomalus Bouvier}

Paguristes anomalus Bouvier, 1918, p. 6, 5 flgs. --Gordan, 1956, p. 321.

MATERIAL EXAMINED: F1ve specimens from Key West, rla., Aug. 20, 1958; E. I. Plerce; 3 males, 2 females.

RANG; Florida Keys and Cuba; 11ttoral.

DIAGNOSIS: Shield nearly $1 \frac{1}{2}$ times as long as wide. Eyes much shorter than width of shleld; eyestalk more swollen at base than at cornea. Perelopod and shleld rose 


\section{1.}

colored. A small species.

DESCRIPTION: Shield two-thirds as wide as long, nude and evenly convex. Frontal margin thickened between elon. gate rostrum and lateral teeth. Eyes short, swollen basally, slightly so at cornea. Eye scales separated by rostrum, bif1d at t1p. Antennular peduncles not exceeding eyes. Antennal peduncles reaching cornea, flagellum short, seldom reaching chelae; each articulation with a eircle of minute setae.

Chelipeds short, laterally compressed, Merus and Ischium with a row of even denticles on inner ventral margin. Carpus and manus armed with corneous-tipped spinules on Inner dorsal margin. Dorsal surfaces of carpus and chela quite flat, with an outer margin of dense, pilose hair. Granular dorsal surface obscured by an even, Iine pubescense. Cutting edges of fingers uneven, with corneous edges near tips.

Walking legs short, compressed in all segments; dorsal and ventral margins carry a dense cover of fine, plumose hair. Dactyls with a fow corneous spinules ventrally; claws strong. Rasp on propodus of fourth perelopods three scales w1de. Only two or three seales appear on dactyl next to short claw. Fifth perelopods with rasp covering distal third of chela. First pair of gonopods heavy, moderately seperated. Medlan cleft of telson shallow; margin supporting sparse setae and, laterally, a few denticles. 
MEASUREMENTS ( $\mathrm{mm}_{\mathrm{m}}$ ): Male Prom Key West. Shield, length 3.2 , width 2.3 , earapace 4.8 , eyes 1.8 , chela, length 2.7, width 1.3, dacty1 1.7, th1rd right pere1opod, bas1s_1sch1um 1.0, merus 2.1, carpus 1.7, propodus 2.0, dactyl 2.3.

\section{Paguristes cadenat1 Forest}

Pagur1stes eadenati Forest, 1954, p. 353, P1gs. $1-3$.

RANG: Known only from holotype male collected at Fort_de_France, Martin1que.

DIAGNOSIS: (after Forest) Shleld a little longer than posterfor part of carapace. Hepat1c reglons of shleld with one large tooth and two smaller ones. Rostrum elongated, with a small point at tip. Eyestalks a little less than twice as long as distance between lateral teeth. Eye scales simple, acuminate. Antennular peduncles reaching base of cornea of right eye; those of antennae shorter. Acicles long, nearly reaching base of flagellum. latter shorter than carapace.

Chelipeds subequal. Carpus with a large blunt tooth subdistally and deeply excavated ventrally. Propodus twice as long as broad; a large depression in paim. Dactyl less than half as long as hand, cutting edge with a large tooth near base. Fingers spooned at tips, gaping proximally when closed. Carpus and chela covered with mleroscople corneous 
tubercles which are a little larger on carinae limiting de. pressions of carpus and palm.

Walking legs armed only with distodorsal tooth on carpus, corneous spinules on ventral angle of dactyl.

Male pleopods similar to those of Paguristes oculatus (Fabricius).

G1II pairs eleven, each lamella deeply emarginate.

\section{Paguristes denressus Stimpson}

Paguristes depressus St1mpson, 1859, p. 87. --Gordan, 1956, P. 321.

MATERIAL EXAMINED; Eight specimens from Puerto Rico and the Gulanas.

Puerto Rico: Mayaguez Harbor, Jan. 19, 1899, "Fish Hawk"; 1 male, 1 female. La Pena, Mayaguez Harbor; Nov. 9, 1946; W. G. Hewatt; 1 male. Off Polnt Melones; 7t fms. Jan. 25, 1899, "F1sh Hawk" sta. 6072; 1 juv. male. Between Ratones and Caribe Ids, off Tallaboa; July 8, 1915, R. C. Osburn; I Juv, Penale. Mayaguez; Jan. 19, 1899; "F1sh Hawk", 2 juv, female.

British Guiana: $07^{\circ} 45^{\prime} \mathrm{N},, 57^{\circ} 34^{\prime} \mathrm{W}, 30-35 \mathrm{fms}, 3$ Aug. 31, 1958, "Oregon" sta. 2248; 1 juv, male.

Erench Gulana: Labeled "Oregon" 2320, undoubtedly an error since that station was at a depth of $200 \mathrm{fms}$. More Iikely from sta. $2321 \mathrm{a}$ or b, both at $06^{\circ} 52^{\prime} \mathrm{N} ., 53^{\circ} 18^{\prime} \mathrm{W}, \mathrm{s}$ 


\section{4.}

34 Ims.; Sept. 14, 1958, 1 small male.

RANGE: Puerto R1co to Surinam; to $34 \mathrm{fms}$.

DIAGNOSIS: Body and chelipeds compressed vertically. Eyes subequal to shield. Faces of chelae covered with scale-like tubercles which are tufted but unarmed.

DESCRIPTION: Shield flat, margin thickened on either side of rostrum to lateral teeth and more indented there than at anterolateral angles. Rostrum slender, exceeding lateral teeth. Posterior part of carapace twice as wide as shield.

Eyes long, little shorter than shield. Eye scales separated, simple, with one or two denticles at tip. antennular peduncles subequal to eyes. Antennal peduncles short, reaching about two-thirds length of eye. Second segment of antennal peduncle with a low, conical swelling at center, a minute spinule on Inner angle; outer projection bifid Into two spinules. Acicle short, reaching midway on eye; with three spinules on inner proximal half, three or four on outer distal half. Flagellum short, almost nude; length near that of carapace.

Chelipeds flattened, left chela normally broader than right. Dorsal angle of merus broadened distally, with a smooth area along distal margin bordered posteriorly by a low escarpment. Dorsal surface of hand covered with scale_ 11ke tubercles, each with a minute, pubescent tuft. Carpus and palm with stout, short spines on inner dorsal edge. 


\section{5.}

Outer margin of hand increasingly sharp distally. Fingers meeting throughout.

First walking legs with carpus spined on inner and distodorsal margins. Propodi and dactyls of both walking legs with a serrate or scalloped edge dorsally; a dense brush of reddish-yellow setae rises from dorsal margin of dactyls. Propodus of fourth perelopods with triangular rasp on distal half of ventral margin; dactyl with row of four corneous scales behind stout tip. Fifth perelopods with large rasp covering distal three-fourths of hand, including most of dactyl.

Gonopods of male stout, well separated basally. Un. paired pleopods large, with dense fringe of p1lose halr; outer ramus obsolescent. Terminal abdominal appendages not unusually asymmetrical. Three or four spinules posteriorly on distal margin of base of left uropod. Telson narrow, margins of lobes armed with even tubercles.

COLOR: Carapace and antennae pink, mottled with coral. Perelopods similarly colored, with motting tending to occur In broad bands on carpi and propodi of walking legs, abdomen suffused with apricot and salmon. Eye stalks and antennular peduncles solid orange chrome. Cornea black.

MEASUREMENTS (man): Male collected by W. G. Hewatt. Shield, length 12.0 , wiath 10.5 ; carapace 21.0 ; eyes 11.2 ; chela, length 14.5 , width 11.0 ; third perelopod, basis1schium 6.7 , merus 10.0 , carpus 8.0 , propodus 9.0 , dacty 1 


\section{6.}

17.2 .

REMARKS; This species is closely related to Paguristes diguet1 Bouvier and Raguristes sanguinimanus Glassell but differs from these Pacific coast species chlefiy in the ornamentation of the chelae, the Pacific species presenting spinulose tubercles rather than turted ones.

\section{Paguristes Lorest1 n. sp.}

MATERIAL EXANTNED; Holotype male; Tortugas; 64 feet; June 26, 1931; W. L. Schm1tt.

RANGE: Known only from type.

DIAGrosIs: Chelipeds flattened above, finely pubescent, margined with corneous-tipped denticles. Medium-sized species similar to $\mathrm{R}$. anomalus Bouvier but several times larger.

DESCRIPTIOII: Shield evenly convex; some fine pubes. cence laterally and anteriorly. Rostrum triangular, covering ophthalmic ring. Cardiac plate narrow, with ealcified, furrowed areas on either side. Eyes shorter than shield, not dllated distally; stalks porcellanous but supporting pilose setae at bases. Eye scales short, forming a single spine. Antennular peduncles a little longer than those of antennae but not reaching cornea. Antennal plagella shorter than chelipeds; articles short, with minute setae at each joint.

Chelipeds flattened dorsally on earpus and chela; these 


\section{7.}

segments feebly armed with corneous spinules on both mar. gins. Spinules scattered, not in distinct rows; sparse on distal part of palm. Margins raised proximally on fingers. Lattex strong, closing completely.

Walking legs strong, exceeding chelipeds. Dorsal angles of last three segments of first pair armed with minute corneous spinules. Second pair with a spinule at a1stodorsal angle of carpus. Setae mainly pilose except on upper and lower angles of dactyls. Claws short, dark; flanked by dark setae.

Fourth perelopols stout, flattened. Propodal rasp a narrow triangle on distal two-thirds of ventral margin; four scales on dacty1. Chelae of fifth perelopods with rasp on distal three-fifths. Telson asymmetrical, unarmed, lacking a median indentation.

COLOR, After 28 years in alcohol a considerable a. mount of light red color st111 persists on first three palrs ofperelopods as 1rregular blotches surrounding small wh1te spots.

MEASURENENT (mm.): Shield, length 6.0 , width 4.8 ; carapace 10.5 ; eyes 5.2 ; chela, length 6.8 , width 3.2 , dactyl 4.0; third right perelopod, bas1s-1schium 2.9, merus 5.1, carpus 4.0, propodus 5.0, dacty 16.9 . REMARKS: While this species somewhat resembles the much smaller P. anomalus, it is most closely related to $\mathrm{P}$. pculatus (Fabricus). Both have short antennae with a pilose 


\section{8.}

tuft at the tip. In oculatus, even denticles with blunt spines cover the faces of the chelae and the left chela is a little larger than the right. The gonopods of the proposed new species are closer to those of oculatus than to any other specles.

This specles is named in honor of Jacques Forest, the foremost student of this genus of pagurids.

\section{Paguristes hewatt1 n, sp.}

MATERIAL EXM/TNED: Holotype male, USNM 97658, para_ type males, USMM 97659 and one other, Heald Bank, Sabine, Texas, 1955, W1111s G. Hewatt.

RANGE: Known only from Heald Bank.

DIAGNOSIS: Chelipeds heavy. Dorsal surfaces of carp1 and chelae not obscured by pllose halr, Large distal pro_ tuberances on carpus of chellped just behind dorsal hinge joint.

DESCRIPTION: Closely related to Paguristes tortugae Schmitt. Differs from that specles in the following points: Reaches larger size. Chelipeds lack dense pubescence on dorsal surfaces. Scale_like tubercles of carpus and chela clearly visible; each tubercle with a distal fringe of minute hairs. Median dorsal ridge on carpus terminating in a prominent elevation. Horny finger tips and flanking tufts of setae darker than in tortugae. 
Eye scales shorter, with only two distal spinules.

MEASUREMENTS (mm.): Sh101d, length 6.3 , w1dth 5.0 , carapace 10.5 , eyes 4.0 ; chela, length 6.5 , width 3.4 , dacty1 4.3; third perelopod, basis-1schium 2.5, merus 4.4, carpus 3.6 , propodus 4.0 , dactyl 5.0 .

\section{Paguristes grav1 Bened1ct}

Paguristes grav1 Benedict, 1901, p. 146, p1. 5, P1g. 1. -.-Gordan, 1956, p. 322.

Pagurus 71110sus Torralbas, 1917, p. 601. Not Pagurus villosus N1colet, 1849, p. 188.

MATERIAL EXAMINED: Fifteen specimens from five areas.

Types: Puerto Rico, San Juan, San Anton10 Bridge; G. M. Gray; 2 males, 1 large female.

Elor1da: Tortugas; July_Aug., 1930; W. L. Schm1tt; 1 large female; Long Key Shoal, eel grass; $3-4$ feet; Aug. 7, 1924; W. L. Schm1tt, 2 males; rocks below Loggerhead Key lighthouse; July 24, 1930, 1 female in shell of strombus LLgas LInnaeus; Bush Key Reer; July, 1930; W. L. Schmitt; 1 male, earapace length $35 \mathrm{~mm}$. Long Reef, Monroe Co.; Apr. 19, 1958; G. Shinn, I male.

Haiti: Reef east of Tierra Baja Road, Tortugas Ids.; $\frac{1}{2}$ Im.; Mar. 21, 1937; W. L. Schm1tt; 2 Juv. Pemales.

British Honduras: P. W. Shufelat, 3 males. Barbados: Antigua, P11lars of Hercules; Jan. 7, 1918,

1 male. 


\section{0.}

RANGE; Florida Reys to Barbados; littoral.

RFMARKS: Th1s species, largest of the western Atlantic Paguristes, while attaining a size twice as large

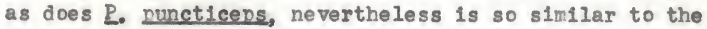
latter specles that alcoholle specinens can only be deter. mined by the much smaller amount of setae present and the much greater number of corneous-tipped spinules on the chelipeds and walking legs. The rostrum varies from a blunt triangle equaling the lateral teeth to a narrow point covering the ophthalmic somite. The transverse sulcus behind the rostrum is straight and the median sulcus extend. Ing back from it is deeper. No difference is ovident in the male gonopods.

COLOR, Specimen from Monroe Co, after two months in formalin. Wine ground color on carapace and appendages, thickly spotted with white. Pattern seemingly differs most In eyestalks which have many larger white spots and only a Iew swall ones; dark ground color extends almost to corneas. MEASUREMENTS (m.): Large female; shleld, length 19, width 16, carapace 30 ; eyes 13. Small male, shleld, length 8.5 (rostrum rudimentary), width 7.5 , carapace 13.5 , eyes 6.5 . REMARKS: It is possible that the Pagurus v1liosus of Torralbas could be Paguristes puncticens. However, most of the evidence points to its reing the present species 3 grayl seems to retain color markings better in preservative and it attains a much larger size. 
Paguristes Lyman1 M1Ine Edwards and Bouvier

Paguristes 1yman1 Milne Edwards and Bouvier, 1893, p. 49, pl. 4, 11gs. 13-22. _-Gordan, 1956, p. 322.

MATERIAL EXAYINED; Twenty-seven specimens from elght localities.

North Carolins: $34^{\circ} 05^{\prime} \mathrm{N} ., 76^{\circ} 10^{\prime} \mathrm{W} . ; 82-100 \mathrm{fms.}$ Feb. 27, 1940; "Pel1can" sta, 187-4; 1 male, 1 female, in shells of phallum; carapace length of male $17.7 \mathrm{~mm}$. ofe St. Augustine: $29^{\circ} 55^{\prime} \mathrm{N} ., 80^{\circ} 10^{\prime} \mathrm{W} . ; 180-220$ Ims.; Dec. 5, 1956; "Combat" sta. 185-187; 1 female. Stralts of Flor1da: Miam1 Beach; $72 \mathrm{fms}$; Aug. 25. $1951_{3}$ F. M. Bayer; 1 juv, male. $24^{\circ} 21^{\prime} \mathrm{N}_{0}, 81^{\circ} 52^{\prime} \mathrm{W}, 3$ Feb. 19, 1902; "rish Hawk" sta. 7282; 2 males, 1 ovig. female. Following specimens collected by J. B. Henderson at Key West In 1916: Western Dry Rocks; 65-90 fms.; 3 males, 3 females ( 1 ovig.), South of Key West on edge of Pourtales Plateau, 2 In shells of Scaphella dohrni (Sowerby); Sambo Key; $115 \mathrm{fms.;} I$ remale. $24^{\circ} 13^{\prime} \mathrm{N} . ; 81^{\circ} 42^{\prime} \mathrm{W}_{\bullet} ; 300$ Ims.; July 21, 1957; "Combat" sta. 436; I male. Sand Key, 15 Ims.; March 29, 1878; "Blake"; 1 male which, although not shelved with the types, is evidently the holotype. West of Rosalind Banks $16^{\circ} 39^{\prime} \mathrm{N} ., 82^{\circ} 29^{\prime} \mathrm{W}, 325$ Prs.; Aug. 21, 1957; "Oregon" sta. 1870; 1 female. $16^{\circ} 41$ ' N., $81^{\circ}$ O2' W.; 250 fms.; Aug. 23, 1957; "Oregon" sta. 1888; 2 males, 1 ovig. female. 
Guadeloupe: 15 Ims.; "Blake" sta. 166; 1 Iemale. off mouth of Orinoce: $09^{\circ} 45^{\prime} \mathrm{N}$., $59^{\circ} 45^{\prime}$ W.; 200 Ims.; Nov, 4, 1957; "Oregon" sta. 1989, 1 male, 1 ovig. Pemale.

Oef Surinam: $07^{\circ} 30^{\prime} \mathrm{No}, 54^{\circ} 16^{\prime}$ W.3 125 Ims.; Nov, 8, 1957; "Oregon" sta. 2013; 1 male.

off mouth of Amazon: $01^{\circ} 45^{\prime} \mathrm{N} ., 46^{\circ} 46^{\prime} \mathrm{W}_{0}, 275 \mathrm{fms.3}$ "Oregon" sta. 2084; 1 female.

RANGE; North Carolina to mouth of Amazon; $15-878$ IIIs. (Milne Edwards and Bouvler, 1893), otherwise 65-300 Ims. This species was not taken in the "Atlantis" collections around Cube or by W. L. Schmitt in h1s extensive Tortugas collecting; nor has it been taken in any other part of the Gule of Mexico.

DIAGNOSIS: Eyes about two-thirds as long as shleld, cornea not swollen. Many lightly calclfied plates forwed on gill cover, somewhat as in Isocheles. Straw colored setae abundant on perelopods, particularly on walking legs. On paired pleopods of male uniramous.

DESCRIPTION: Shield with margin across entire front; rostrum not exceeding lateral teeth. Only sizeable depress. fon of carapace lies Just behind rostrum. Numerous punctae with short setae on lateral regions. Cardiac plate narrowed to a point posteriorly, partly bordered by a more calcified plate on each side. 


\section{3.}

Eyes small, slightly swollen at each end. Stalks with a dorsomedian line of setae. Eye scales small, with a minute apical spinule. Extended antennular peduncle has term1nal segment beginning at level of base of cornea. Antennal peduncle not reaching cornea; armament of acicle concealed by long setae which extend over eyestalk and exceed cornea. Antennal Plagellum short, reaching dactyl of chela; several fine setae at each joint.

Chelipeds armed on Inner dorsal margins, usually with plve spines on carpus, four on palm. Face of chela appears poreellanous, w1th many corneous-tipped denticles and more numerous tufts of setae. Fingers meet only along corneous cutting edges of tips. Calcareous teeth of gape edges strong. Dactyl covered with small corneous spots medially which apparently act as friction points.

Walking legs strong, the first with a few dorsal spinules on carpus and propodus. Dense setae on dorsal and ventral margins. Dactyls heavy, claws weak. Rasp of fourth pereiopods four scales wide distally; only four corneous scales on dactyl. Chela of f1fth with rasp on distal two_fifths.

First pair of male gonopods strong, separated by a space equal to terminal segment of one member. Unpaired male pleopods uniramous. Female carries about 300 eggs 1.0 $\mathrm{mm}$. In dlameter. Base of left uropod armed with two or more denticles posteriorly. Terminal lobes of telson armed with 
small corneous_tipped denticles.

COLOR: Specimen from "Oregon" sta. 1989 in formalin. Rose in varying intensity on carapace; on head appendages except dorsally on eyestalks; and on perelopods, with color fading to white at joints, dorsal surface of chela and all dactyls.

MEASUREMENTS (m.): Shleld, length 8.7, wiath 8.5; carapace 14.5 ; eyes 5.6 ; chela, length 11.6 , wiath 6.0 , dactyl 7.7; third right perelopod, basis_ischium 5.1, merus 8.0 , carpus 6.7 , propodus 7.8 , dactyl 12.8 .

\section{Paguristes moore1 Benedict}

Pagur1stes moore1 Benedict, 1901, p. 144, pl. 4, flg. 3. --Gordan, 1956, p. 324.

Paguristes taeniatus Benedict, 1901, p. 143, key (nomen nudum).

MATERIAL EXAMINED; Twenty-three specimens from Cuba, Puerto Rico, and Saba Bank.

Holotype female, USNM 29207, "Puerto Rico, Fish Havk.".

Cubs ("Atlantis" Harvard_Havana Expedition), 22 $13^{\circ}$ N., $81^{\circ} 11$ ' W.; 185-195 fms.; Apr. 6, 1939; sta. 3394; 1 female, $22^{\circ} 34^{\prime} \mathrm{N} ., 78^{\circ} 16^{\prime}$ W. 180 Ims.; Apr. 28, 1939, sta. 3397 , 1 male. $22^{\circ} 43^{\prime} \mathrm{N} ., 78^{\circ} 40^{\prime}$ W. 200 Ims. 3 Apr. 29, 1939; sta. 3408 ; 1 female. $22^{\circ} 50^{\prime} \mathrm{N} ., 78^{\circ} 52^{\prime} \mathrm{W}_{0}$; 230 fms.3 Apr. 29, 1939; sta. 3414; 8 males, 2 females (one 


\section{5.}

ovig.). $22^{\circ} 50^{\prime} \mathrm{N},, 78^{\circ} 55^{\prime}$ W.; 200 Pms.; Apr. 30, 1939; sta. 3416; I male, $22^{\circ} 49^{\prime} \mathbb{N}_{0}, 79^{\circ} 00^{\prime} W_{*} ; 195$ fms.; Apr. 30,1939 ; sta. $3418 ; 1$ ov1g. Pemale, $22^{\circ} 461 \mathrm{~N} ., 79^{\circ} 00^{\prime}$ W.; 180 fms.; Apr. 30, 1939; sta. 3418, 1 male, 5 females (4 ov1g., I juv,). $23^{\circ} 09^{\prime} N_{0}, 81^{\circ} 27^{\prime} W_{0} ; 175$ fms. 3 May 9, 1939; sta. 3465 ; 1 female.

Lesser Ant11les: $17^{\circ} 33^{\prime} \mathrm{N} ., 63^{\circ} 35^{\prime}$ W.; $125-132$ Ims.; Sept. 25, 1958; "Oregon" sta. 2356; 1 male in Murex shell. RANGE; Cuba to Saba Bank; 132 to 230 Ims.

DIAGNOSIS: Body compressed dorsoventrally, almost nude. Eyestalks at least equaling shield. Dorsal surface of chela covered with denticles.

DESCRIPTION: Shleld slightly longer than wide. Frontal margin thickened, especially toward lateral teeth, with a short break here before margin continues posterolaterally to terminate at spinule beneath anterolateral angle. Rostrum and lateral teeth with a minute spinule at tip. Rostrum scarcely reaching ophthalmic ring. Posterolateral prom1nences with one spine, one or two spinules, and several denticles. Anterolateral areas spinulose laterally; sepa. rated from margin by narrow grooves. Cardlac plate and adjacent parts of carapace well calcifled.

Eyes slightly longer than shleld, more swollen distally than basally. Eye scales well separated, short, and tipped with a spinule. Extended antennular peduncle exceeds cornea by half of distal segment. Second segment of antennal pe. 


\section{6.}

duncle swollen medially; inner angle with a denticle, outer with a strong, bifld spine. Aclele long, four spines on proximal half of Inner margin, none to two above this level on outer margin and two forming a blfureate tip. Distal segment of peduncle not reaching cornea. Flagellum twice as long as carapace, with numerous but very short and Iine setae.

Chelipeds strong, with five or six blunt spines on Inner dorsal angle of carpus and propodus; denticles covering remainder of dorsal surface. Sparse, stiff setae $r$ ise from bases of denticles, chiefly on fingers. Chela narrow, twice as long as wide. Fingers meet along distal fourfifths of cutting edges. Worn, corneous edge covers over half of cutting edge of dactyl, with about five teeth on proximal part; opposite edge on pollex composed of about 12 Low calcareous teeth.

Carpus of second pereiopods with six spines on inner dorsal angle, propodus with eleven. Straw colored setae border rows of splnes on dorsal surface. Dactyl long, with two dorsal rows of dense setae and one ventral. Ventral angle marked by row of fine, corneous spinules. Third perelopods lack spines except for one directed forward on anterodorsel margin of carpus. Corneous tips of all dactyls minute.

Fourth perelopods with narrow, triangular rasp on distel two-thirds of ventral angle of propodus. Dactyl 
bears about nine sma11, corneous scales behind claw. Fifth perelopods with rasp covering distal half of chela.

Gonopods little separated basally. Second pair on male reaching well beyond first pair, densely setose at tips. Coxal openings on male covered by first pair of gonopods along inner edge. Unpaired pleopods on male feebly biramous. Marsupium of female well developed, translucent.

Basal segment of left uropod armed with numerous small spines, mainly in two irregular rows; largest spines marginal. Telson unusually asymmetrical, unarmed.

COLOR: Male in formalin four months. Eyestalks scarlet except for broad white stripe on Inner dorsal surface. Antennal flagellum translucent proximally, carmine distally. Merus of chellpeds with a transverse crimson bar distally on sides. Band on merus of walking legs smaller and less distinct. Shleld and dorsal surfaces of perelopods light salmon.

MEASUREMENTS (mm.): Male from "Atlantis" sta. 3414. Shield, length 8.8 , width 9.5 ; carapace 15.3 ; eyes 8.5 ; chela, length 14.8 , width 8.0 , dacty 19.6 ; third right perelopod, bas1s-1sch1um 7.3, merus 9.7, carpus 7.2, propodus 9.0 , dacty 1.6 .5 .

Paguristes planatus Milne Edwards and Bouvier

Pagur1stes Dlanatus M1lne Edwards and Bouvier, 1893, p. 
43, p1. 4, P1gs, 1.5. --Gordan, 1956, p. 323.

RANGE; Barbados; $100 \mathrm{fms}$. Known only from holotype female at MCZ.

DIAGNOSIs: (after Milne Eâwards and Bouvier, 1893) Cephalothorax extremely flattened. Carapace wider than long. Shield with lateral borders armed with spinules. Rostrum obtuse, lateral teeth tipped with a spinule. Car. diac plate broad. Eyestalks shorter than front, equaling peduncles of antennules, exceeding those of antennae. Eye scales small, unequally bidentate at tips. Antennal acicle with three or four spines on outer edge, five or six on inner, tip bifurcate. Flagellum nude, short. External maxillipeds separated by a rather broad calcareous sternum. Chelipeds short, surpassed by walking legs. Carpus with three strong spines on inner margin, four or five on outer and several spinules between margins. Two irregular rows of three spines on inner border of hand. Walking legs with two rows of spinules on carpus, four on propodus. Dactyl nearly as long as two preceding segments.

\section{Paguristes puncticens Benedict}

Paguristes puncticens Benedict, 1901, p. 144, p1. 4, Pig. 4. --Gordan, 1956, p. 323.

MATERIAL EXAMINED; Fifteen specimens from three areas. Types: Jama1ca; Mar. 1-11, 1884, "Albatross"; 10 males, USNM 29203. 
Florida: "Florida, coll. by sponge fishermen, don. by L. L. Hubbard, in rare encrusting bryozoan, Hipnoporidra edax Busk"; 1 dry specimen, eyestalks with white spots bordered by red on pink background. Key West, shallow ree?; Aug. 21, 1958; E. L. Pierce; 1 male, 2 Pemales (I ovig.). Cuba: Varadero, Cardenas Bay, Hicocas Peninsula, off E. 1st. St., dredged along shore; Jan. 24, 1957, W. L. Schmitt, I ovig. female in shell of Strombus pug11is alatus Gmelin.

RANGE; Florida Keys to Jamaica; littoral.

DIAGNOSIS: Anterolateral angles of shield not reach. ing level of recesses in margin behind eyestalks. Eyestalks very little constricted, cornea not dilated. Stalks marked by a lew white spots visible to the naked eye and abundant microscopic spots.

DESCRIPTION: This species is very closely related to P. sericeus, less closely to P. grayl. The diagnosis and following description are given to point out differences between this species and sericeus.

Shield considerably longer than broad. Cardiac plate narrow, much constricted about one_third of distance from anterior end. Eyes about three-fourths as long as shield. Cornea not as broad as basal and distal ends of stalk.

Chelipeds armed near margins with strong spines and denticles, all with dark corneous tips.

Male pleopods exhibit no apparent differences. 


$$
90 .
$$

COLOR: Specimens from Key West after one month in alcohol. Carapace and perelopods mainly rose red shading to rose pink, sprinkled with white dots usually bordered by carmine. Distal parts of walking legs carmine to erimson. Chela red above with eream to bupf tubercles. Eyestalks carmine with about 20 white spots visible on each dorsal surface and a great many minute white spots, giving the background a ret1culate appearance. Stalks salmon next to cornea.

MEASURBNeNS (mm.): Kale from Key West. Shield, length 11.8, width 10.1; carapace 19; eyes 8.8. Other parts of body are similar in proportion to those of $P$. sericeus.

REMARX: P. Duncticens is apparently a reef form whereas $\mathbf{R}$. sericens is found at generally greater depths and on shell bottoms. While Iresh material of the two species is easily distinguished, bleached alcoholic speci. mens are rather difficult to identify.

\section{Paguristes sav1 Milne Edwards and Bouvier}

Paguristes say1 Milne Edwards and Bouvier, 1893, p. 55. pl. 5, 11g. 1.7. _-Benedict, 1901, p. 143 (key), p. 144, pl. 4, 11g. 2.

MATERIAL EXAMINED, Nine specimens from elght local. 1t1es. 
Holotype male, Barbados; $288 \mathrm{fms.3}$ "Blake."

Eloride: Off St, Augustine; 263 fms. "Albatross" sta. 2655, 1 male.

Cube: South of Cuba; 400 fms.; "Albatross" sta. 2128, 1 Juv, female. $20^{\circ} 45^{\prime} \mathrm{N},, 75^{\circ} 20^{\prime}$ W. 230 frs.; Apr. 20, 1939; "Atlant1s" sta. 3375; 2 males. $22^{\circ} 33^{\prime} \mathrm{N} ., 78^{\circ} 10^{\prime}$ W.; 245 fms.; Apr. 26, 1939, "Atlantis" sta. 3387, I male.

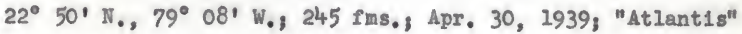
sta. 3423 ; 1 female, $23^{\circ} 21^{\prime} N_{.}, 79^{\circ} 55^{\prime}$ W.s 375 fms.; May 3, 1939, "Atlant1s" sta. 3447; 1 female.

Puerto Rice: Mayaguez, 1 female, probably collected by "Fish Hawk:"

RAIGE: Florida to Puerto R1co, 230 to $400 \mathrm{fms}$.

DIAGNOSIS: Shield broader than long, eyes short, eye scales with four terminal spinules.

DESCRIPTION, Shleld somewhat heart-shaped, slightly broader than long; margin thickened across ent1re front. Rostrum rounded, shorter than lateral teeth. Cardac plate long, triangular, widest at cervical groove. Shleld with a trlangular calcifled plate on either side posterolaterally.

Eyes less than three-fourths as long as shield, some. what swollen at both ends. Eye scales with four terminal spinules, second spinule from inside longest. Spinules hldden by setae arlsing more posterlorly on scales. Antennular peduncle exceeds eyes by length of terminal segment. Second segment of antennal peduncle lacks spine on Inner 
angle; two appear on short, outer projection; base with a conspicuous depression. Third segment of peduncle slightly exceeds cornea. Acicle long, exceeding cornea, with flve or s1x spinules on inner margin, three or four on outer; long, fine setae rise from numerous punctae on Inner dorsal surface.

Chelipeds spined on inner margin of carpus; hand quite smooth dorsally. Ischium with a row of six small tubercles on inner ventral margin; merus with eight spines in same position. Inner dorsal surfaces of carpus and propodus each armed with four strong spines. A small terminal spine on carpus behind articulating socket, a second at dorsolateral angle. Two rows of low tubercles appear behind gape on hand. Sparse setre stem from these and other tubercles on hand and, more thickly on Pingers. Usual corneous cutting edges composed of many, minute plates on distal part of dactyl meeting broad, corneous tip of pollex, Fingers gaping except at corneous tips.

Merus of second perelopod with an even row of 12 sharp denticles on ventral angle. Carpus armed with five or $\$ 1 x$ spines on dorsal surface, three spinules on inner distal margin below anterodorsal spine. Nine evenly spaced spines on dorsal angle of propodus. Seven or more minute tubercles form a short row on proximal dorsal angle of dactyl of second perelopods. Dactyl of walking legs with a row of scale_ like, flexible setae on ventral margin. Third perelopods 
unarmed except for single distodorsal spinule on carpus.

Fourth perelopods with narrow rasp about three seales wide covering almost three-fourths of propodus. Coxa with crest of four small denticles on proximal anterior angle.

Male gonopods separated by a moderate distance basally. Unpaired pleopods with a feeble external ramus. Uropods extremely unequal, those on left about four times as large as on right. Telson also asymmetrical, terminal lobes evenly armed.

MEASURENENTS (mm.): Shleld, length 9.3; w1dth 10.0 , carapace 15.0 , eyes 5.6 ; chela, length 10.6 , width 5.8 , finger 6.6 , third leg, basis-1schium 6.3, merus 8.1 , carpus 6.4 , propodus 7.6 , dacty 114.0 .

\section{Pagur1stes ser1ceus A. M1lne Edwards}

Pagur1stes sericeus A. Milne Edwards, 1880, p. 44. -_Balss, 1924, p. 178. -Gordan, 1956, p. 324.

Paguristes rectifrons Bened1ct, 1901, p. 145, p1.4, 11g. 7. --Gordan, 1956, p. 324.

Paguristes tenuirostris Bened1ct, 1901, p. 143, p1. 4, f1g. 1. --Gordan, 1956, p. 324.

MATERIAL EXAMINED; Seventeen specimens from the coasts of two states and two 1slands.

Texas: Heald Bank, off Sab1ne, W. F. Howatt; 1 male (Iden, by F. A. Chace, Jr., with remarks, "Eyestalks unlform 
94.

red_orange, not spotted").

Flor1de: Off Fort Welton; 14_15 Ims.; June 3-4, 1947; Frank Lyman; 1 ov1g. Pemale. Off Cape San Blas, $29^{\circ} 28^{\prime} \mathrm{N}$. , $85^{\circ} 31$ ' W.; 12 fris.; Feb. 1, 1956; "A. A. Jakkula"; 3 males, 3 Pemales. $2 \mathrm{ml}$. south of Alligator Point, Franklin Co.; July 10, 1957; 3 fms.; H. J. Humm; 1 female in shell of Strombus pug1lis alatus Gmelin. Deadman Bay, $29^{\circ} 35^{\prime} \mathrm{N}$. ,

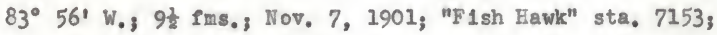

1 female. $213 / 4$ mi. N.E. Cedar Key L1ght; $5 \frac{1}{2} \mathrm{Ims}$., Jan. 11, 1913; I juv. female in shell of Junonfa. Off Anclote Keys; $28^{\circ} 58^{1} \mathrm{~N} ., 83^{\circ} 54^{\prime}$ W.; $10 \mathrm{fms.,} \mathrm{Nov.} \mathrm{7,} \mathrm{1901;} \mathrm{"F1sh}$ Hawk;" I male. North of Tortugas; $25^{\circ} 38^{1} \mathrm{~N} ., 83^{\circ} 18 \mathrm{l}$.; 33 fms., Mar. 2, 1889, "Grampus" sta. 5077, 1 Juv. Pemale (type of $P$. tenuirostris, USIM 20224). Off Miam1; $30 \mathrm{fms} .3$ J. B. Henderson; 1 female.

2Jamaica: $17^{\circ} 36^{\prime} \mathrm{N}$., $76^{\circ} 46^{\prime}$ W.; 966 fms.; Mar. 11, 1884; "Albatross" sta. 2140; 1 male, right chela much smaller.

Puerto Rico: Mayaguez Harbor; 80 Ims.; Jan, 20, 1899; "F1sh Hawk" sta. 6065; I juv, male in shell of Conus. OPf V1eques Id., Puerto Rico, 14 fms., Feb. 8, 1899, "Fish Hawk" sta. 6085, I male from shell of Strombus pug1111s alatus Gmelin (type of P. rectifrons, USNM 29204).

RANGE; Texas and Florida to Guadeloupe; 3 to $36 \mathrm{fms.3}$ records at 80 and $966 \mathrm{fms}$. are doubtful.

DIAGNOSIS: Eyes long, stalks somewhat narrowed between base and cornea. Anterolateral angles of shleld even with 
marginal depressions on either side of rostrum. Carapace flattened, broad; walking legs widely separated by sternal plates. Chela llattened, covered with fine halr; corneous tips of spinules light jellow. Color of eyestalks solld. DESCRIPTION: Shleld longer than broad; frontal margin raised between lateral teeth. Rostrum long, triangular, variable in length, usually exceeding ophthalmic ring. Gastrie region bordered laterally and anterlorly by a groove which mirrors frontal margin. Shleld swollen at the lateral angles, with several spinules aprearing on posterior part of raised area. A broad depression separates each anterolateral area from a small area behind $1 t$; latter has a few anterlorly directed, short spines. Posterior part of carapace w1th calc1fled mid-region cut by many long1tudinal furrows.

Eyestalks long and somewhat swollen at both ends. Each stalk with a row of 7 or 8 punctae, from which pine setae arlse, mediad of dorsal midine. Eye scales narrow, triangu. lar, with a spinous t1p.

Antennular peduncle not reaching cornea. Second segment of antennal peduncle with three spines, a minute one arising from an elongate protuberance below aclele and two at lateral apex. Terminal segment bears two or three sharp spinules on proximal half of dorsal angle. Acicle with two strong spines on inner margin and two on outer, plus a ter. minal spine. Flagellum thin, short, barely surpassing 


\section{6.}

carpus of cheliped; a fringe of minute setae at each ar. ticulation.

Dorsal surfaces of carpus and chela dent1culate, denticles larger and tipped with corneous spines toward margins. Merus with a few small spines on ventrolateral margin. Dorsal surface of carpus with numerous spinules, largest near inner edge. Surface of chela similar to that of carpus, much more setose. Tips of fingers spooned.

Walking legs with spines on dorsal surfaces of carpus and propodus. Carpus of second pair with two or more anterodorsal spines separated by a deep groove from a similar group of anterolateral spines. Fourth perelopods with narrow rasp covering two-thirds of distoventral angle. Large rasp of elfth perelopods covering distal two-thirds of chela.

First pair of male pleopods separated at bases by length of one pleopod. Outer ramus of unpaired pleopods in males rudimentary. Base of left uropod armed with a few spinules. Telson asynuetric; borders of lobes spinulose.

COLOR: Similar to that of $\mathrm{P}$. puncticens except that eyestalks are solld red.

MEASUREMENTS (mm.): Female from Alligator Harbor area. Shield, length 9.2, w1dth 9.2, carapace 15.5; eyes 8.1; chela, length 9.2 , width 6.7 ; dactyl 6.1 ; third right pere1. opod, basis_ischium, 4.0 , merus 7.0 , carpus 6.4 , propodus 6.2, dacty1 13.5 . 
RMMARK: The similarities between this species and 1ts close relatives, P. puncticeps and . gravi are discussed under the latter species.

\section{Paguristes sninives A. Milne Edwards}

Pagur1stes sninines A. Milne Edwards, 1880, p. 44. -Gordan, 1956, p. 324.

Pagur1stes visor Henderson, 1888, p. 78, pl. 8, 11g.3.

Prguristes armatus Hay, 1917, p. 73. _-Gordan, 1956, p. 321 .

MATERIAL EXAM INED: Ten specimens from seven locallties.

Off North Carolina: $30 \mathrm{~m}$. south of Cape Lookout light. sh1p, "F1sh Hawk," I juv, male (type of P. armatus).

Oef Florida: $27^{\circ} 28^{\prime} \mathrm{N} ., 78^{\circ} 44^{\prime} \mathrm{W}, 3215$ fms.; Fob. 3, 1957; "Combat" sta. 237; 1 male. $27^{\circ} 27^{\prime} \mathbb{N}_{\bullet}, 78^{\circ} 58^{\prime} \mathrm{W}$, ; 180 Ims. 3 Feb. 2, 1957; "Combat" sta. 235; I female.

Gulf of Nexico: off Florida, $26^{\circ} 04^{\prime} \mathrm{N} ., 84^{\circ} 18^{\prime} \mathrm{W} \cdot 3$ 98 Ims.; May 8, 1952; Robert H. Stewart; 1 male, 1 female.

Cuba: $23^{\circ} 05^{\prime} \mathbb{N}_{0}, 82^{\circ} 33^{\prime} \mathrm{W}_{\bullet} ; 260 \mathrm{fms}, ;$ Mar. 23, 1939, "Atlantis" sta. 3303; I female. $22^{\circ} 50^{\prime} \mathrm{N}$., $78^{\circ} 52^{\prime} \mathrm{W}_{\bullet} ; 230$ Ims.; Apr. 29, 1939; "Atlantis" sta. 3414; 1 male.

Yucatan: Off Arrowsmith Bank; $20^{\circ} 59^{\prime} \mathrm{N} ., 86^{\circ} 23^{\prime} \mathrm{W}$, s 130 Pms.; Jan. 22, 1885; "Albatross" sta. 2354; 1 female. Nartiniave: $191 \mathrm{fms.;} \mathrm{"Blake"} \mathrm{sta.} \mathrm{210,} 1$ male. St. Vincent: 95 fms.; "Blake" sta. 95; 1 juv. male. 
RANGE: North Carolina and northeastern Gulf of Mexico to Pernambuco, Braz1l (Henderson, 1888); 103 to $350 \mathrm{fms.}$

DIAGNOSIS: Body somewhat compressed laterally; first pair of walking legs armed with strong spines. Telson symmetrical, unarmed.

DESCRIPTION: Carapace with entire frontal margin thickened; margin curving beneath anterolateral angles, submarginal spinule at lateral terminus. Rostrum trlanglar, exceeding lateral teeth, barely covering ophthalmic ring. Shallow, transverse groove immediately behind front joined by three longitudinal grooves; medlan groove short, laterals extending posterolaterally to border of shield. Posterior parts of lateral grooves with setose tubercles on elther side. Cardic plate short, calcleled.

Eyes long, equaling shield, curved outwardly and swollen at each end. Stalks with a punctate line of setae dorsally. Eye scales simple, terminating in a single spine. Antennular peduncle reaching base of cornea. Antennal peduncle reaching two-thirds length of eye; second segment with a small spine on inner angle, two on outer. Aclele with two sharp, inner spines near base, another past midpoint, and one at terminus. One or two spines occur opposite third inner spine. Flagellum equaling perelopods, nearly nude. Merus of third maxillipeds with four spinules on lower margin.

Chellpeds exceeding by half length of dactyl of walk- 
Ing legs. Ischium denticulate on Inner ventral margin. Merus with an oblong, rounded boss over one $\mathrm{mm}$. In length on proximal inner ventral border; ventral margins denticulate beyond boss. Dorsal angle of merus with three distal spinules. Carpus and propodus with corneous_tipped, stout denticles dorsally. Fingers close without a gape; corneous cutting edge on distal half of dactyl opposes welded row of calcareous teeth on pollex. Outer surface and lower border of hand with spinous denticles, inner border with large tubercles.

Walking legs sparsely setose on dorsal and ventral angles, laterally on merus of first pair and in numerous punctae on sldes of dactyl; row of punctae on inner surface of dactyl presents longest and densest setae near tip. Carpus of first walking leg with a small, upturned groove on outer dorsal surface; dorsal spines of carpus number three to six; latter number appearing normal. Dorsal spines on propodus of same leg number seven to ten, with ten, or more, spinules on proximal dorsal surface of dactyl. Second walk ing leg unarmed; ischium much longer than in preceding leg, merus shorter, other segments similar.

Fourth perelopods reaching second segment of antennal peduncle in male, base of first segment in female, Propodus with long triangular rasp on vantral surface; dactyl with eight or nine corneous scales in male, five in ferale. Fifth perelopods with rasp on distal half of outer surface. 
Gonopods strong in male, f1rst pair approximated at bases; female with terminal segment narrow and bases more separated. Unpaired pleopods of male with external ramus a minute tubercle. Base of left uropod with ten or more corneous spinules; base of right with these plus a few calcareous spinules. Telson symmetrical, unarmed.

COLOR: Specimens from Saba Bank after 4 months in formalin. Shield with rostrum and anterior margin white, followed by peach red, shading quickly to salmon with a few white spots on rest of shield. Eyestalks faintly grey, cornea black. Antennae buff above proximally, scarlet ventrally to carmine distally. Merus of chelipeds white, with a prominent, transverse band of red just behind distal. margin on each side. Short spinules on dorsal surfaces of carpus and chela scarlet at tips; denticles and background pale buff. Walking legs with similar markings on merus; more distinct on outside. Propodus and dactyl orange buff. MEASUREMENTS (mm.): Male from Saba Bank. Shield, length 11.7, width 7.8 , carapace 18.5 ; eyes 12.0 ; right chela, length 16.0, width 6.2, dactyl 9.1; third right pereiopod, basis.ischium 7.4, merus 11.5, carpus 8.5, pro. podus 10.8 , dactyl 19.0 .

\section{Paguristes tortugae Schmitt}

Paguristes tortugae Schmitt, 1933, p. 7. --Wass, 1955, p. 134. --Gordan, 1956, p. 324. 
MATERIAL EXAMINED: 12 specimens from North Carolina, Florida, and French Gulana.

North Carolina: Southwest of Cape Lookout, $34^{\circ} 33^{\prime}$ N., 76 $41^{\prime}$ W.; 9 Ims.; Feb. 16, 1940; "Pellcan" sta. 1855; 1 male.

Florida (West Coast): St. Teresa, Franklin Co.; Sept. 27, 1952; H. J. Humm, 1 male, USNM 94047. Ten m1. south west of Cedar Key; May 20, 1956; E. L. Plerce; 1 ovig. Pemale. Mullet Key, Oct. 16, 1954; 2 specimens (sent to Par1s Museum). Tortugas (coll. by W. L. Schm1tt), North of Loggerhead 11ghthouse; 20_30 ft.; Aug. 6, 1924; 1 male; off Bush Key Reef; June 19, 1925; 1 ovig. female; Aug. 14, 1930; 2 males, 1 ovig. female; Fort Jefferson moat; Aug. 11, 19,24; 1 male.

French Guiana: Labeled "Oregon" 2320, (see notation under $P$. denressus); 1 ovig. female.

RArGE: Beaufort, N.C., to French Guiana; to $9 \mathrm{fms}$, at Beaufort, 34 rms. off French Guiana.

DIAGNOSIS: Anterior part of body and appendages cloth. ed with fine, plumose hair. Eyestalks and mouth appendages with ringed pattern of color markings. Rasp of fourth pere1. opod Iive to seven scales wide.

DESCRIPTION: (Male from St. Teresa, Pla.) Shield convex, smooth medially, $11 / 3$ times as long as wide; anterior margin thickened, particularly behind eges, Rostrum covers oph. thalmic ring; a minute spinule on each lateral tooth. Two 
deop slits or grooves just posterior to frontal margin are separated by a median bridge. Raised lateral areas spinu 10se. Cardiac plate calcified anteriorly.

Eyes shorter than width of carapace, swollen at base, minutely so at cornea. Eye scales rounded; three spines distally, the outer m1nute. Antennular peduncle equals eyes. Second segment of antennal peduncle with three strong spines on outer projection of small denticle on inner angle. Ventral spine on third segment broad, sharptipped. Acicle with three spines on outer border, one to three on inner border; tip spinous. Flagellum short, barely reaching chela; with short, fine setae.

Chelipeds short, moderately stout; dorsal surface of carpus and propodus and dorsal angle of merus covered with low, scale_like tubercles and ridges from which anteriorly directed setae arise. Strong, corneous-tipped spines on inner dorsal margin of carpus and manus; four on former and three on latter behind dactyl. Fingers gape proximally; tips hoof_shaped, corneous cutting edges extending nearer gape on dactyl than on pollex; low, calcareous teeth on remainder of cutting edges.

Second pereiopods with several spinules on dorsal angles of carpus and propodus. Both walking legs with transverse scale_like ridges on ventral surfaces of carpus and propodus; pilose setae obscuring both ventral and dorsal angles. Fourth pereiopods with rasp on distal three. 
fifths of propodus f1ve to seven scales wide; dactyl lackIng a rasp; chela of fifth palr with a rasp on distal half. Gonopods complex; first pair forming a deep, open gutter. Second pair with terminal segment spatulate, distal part fringed with stiff setae. Inner ramus of first unpair. ed pleopod one-fourth length of outer, rudimentary on last two pleopods, Brood pouch of female only a narrow flap. Telson with several strong spines on distal margin. Posteri. or edge of basal segment of left uropod presents a few spinules.

COLOR: After W. I. Schmitt, (personal notes from Tortugas): Eyestalks with a wh1te band behind black corneas, followed by a band of wine purple, another of white, and a band of diffuse purple ahead of buff color on proximal half of stalks. Peduncles of antennules and antennae banded with purple. Short antennal flagellum with a purple band on each segment.

REMARKS: Comparison of this species with Pacific coast forms reveals a close simllarity with Paguristes tomentosus (H. Milne Edwards, 1848), of which $\mathrm{P}$. anahuacus Glasse11, 1938, is probably a synonym. P. tomentosus is a slightly larger species with fewer corneous spinules on the first three perelopods and signiflcant differences in the male gonopods.

MEASUREMENTS (m.): Male from St. Teresa. Shleld, length 5.3 , width 4.0 ; carapace 8.5 ; eyes 3.5 ; chela, length 
5.0, wiath 2.3, dactyl 2.8; third right pereiopod, basisischium 2.2, merus 3.5 , carpus 3.2 , propodus 3.5 , dacty 5.0 .

Paguristes triangulatus Milne Edwards and Bouvier

Paguristes triangulatus A. Milne Edwards and Bouvier, 1893 , p. 40, p1. 4, P1gs. 6_12. _-Gordan, 1956, p. 324; Springer and Bull1s, 1956, p. 16.

MATERIAL EXANINED; Forty-four specimens from five local1ties.

Type female, Barbados, 73 fms., "Blake" sta. 290. ofe Cane Hatteras: $35^{\circ} 54^{\prime} \mathrm{N}$., $74^{\circ} 25^{\prime} \mathrm{W}$; $75 \mathrm{fms.3}$ June 17, 1957; "Combat" sta. 384; 4 males, 2 females from Phallum and Conus shells.

Northeast of Missission 1 Delta: $29^{\circ} 20^{\prime} \mathrm{N} ., 88^{\circ} 17^{\prime} \mathrm{W}$. ; 33 fms.; "Pelican" sta. 13; 1 male.

Tortugas and Florida Kers: (Specimens collected by W. I. Schmitt unless otherwise stated). South of Loggerhead Key; 40 fms.; 4 males, 2 ovig. females, 1 each in shells of Conus, Murex, D1storsio and Phal1um. Aug. 20, 1931; Paul Bartsch, 7 males, 8 females ( 5 ovig., 1 parasitized), 2 Juveniles, mainly in shells of Pholium, Distorsio, and Polystira. South of Tortugas; 39 fms.; June 26, 1932; 2 males, 5 females ( 3 ovig.); 1 in 0liva shell, others in Distors10 she11s. South of Tortugas; $40 \mathrm{fms}$; Aug. 14, 1933; H. H. Darby; 1 ovig. female. 36-40 fms.; Paul Bartsch; 1 male, 1 female with rhizocephalah parasites; 30 fms., June 11, 
1925, I male in Polystira she11. 40.45 fms.; June 17, 1932; 1 male in Polystirs shell. $24^{\circ} 26^{\prime} \mathrm{N} ., 81^{\circ} 46^{\prime} \mathrm{W}_{03} 45 \mathrm{fms.3}$ Jan. 15, 1885; "Albatross" sta. 2318, 1 male in Murex shell. Off Key West; J. of Iowa sta. 24-60 fms.; June 19, 1893; 1 in Murex cabriti shell.

Cuba: $22^{\circ} 36^{\prime} \mathrm{N} ., 78^{\circ} 22^{\prime} W_{\bullet ;} 210$ fms,; Apr. 28, 1939; "Atlantis" sta. 3403; 1 male in Polystira shell.

RANGE: Cape Hatteras, N.C., to Barbados; 30 to 210 fms. (taken only once below 84 fms.).

DIAGNOSIS: Eyes equaling shield, stalks red. Rostrum triangular. Chelipeds sparsely setose, with spines on inner margins, fine denticles on dorsal surfaces of carpus and chela. First pair of male pleopods approximated.

DESCRIPTIOH: Shield as broad as long. Triangular rostrum slightly exceeding lateral teeth. Margin of entire front more or less thickened. Shield somewhat rugose and sparsely setose anteriorly and laterally. Cardiac plate broadest at ends, narrowest at three-fourths of distance to posterior margin. Gill cover calcifled anteriorly and, lightly so, posteriorly.

Eyes as long as shield, wldest at cornea; each stalk with dorsal line of flne setae. Eye scales well separated, short and with conlcal tips. Ophthalmic somite exposed. Peduncle of antennule exceeding eyes, that of antenna not exceeding. Second segment of antennal peduncle with a minute denticle at inner angle, bifid spine on outer pro- 
Jection. Acicle well armed with four spines on lower inner margin, one above these on outer margin and two at tip. Flagellum flattened, sparsely setose, equaling perelopods.

Chelipeds armed with short spines and strong denticles on Inner dorsal angles, Dorsal surfaces of merus, carpus and palm with spinous denticles; fingers with rounded granules dorsally and laterally. Cutting edges meeting throughout; teeth of pollex calcareous, united, of dactyl corneous on distal half. Tips corneous, minute. Setae fine, evenly dispersed dorsally, plentiful but not ob. scuring surface.

Dorsal splnes on first walking leg include f1ve or six on carpus, nine on propodus and a few proximal spinules on dactyl. Dorsal angles of both walking legs appear scalloped because of even punctae supporting tufts of setae; ventral angles serrate, each serration with a fine, stiff seta. Claws short, thin.

Fourth perelopods with small, triangular rasp on distal third of ventral angle; single row of fine scales on dactyl. Fifth perelopods with a rasp on distal half of chela. First palr of male gonopods short, nearly cont1guous basally. Outer ramus of unpaired pleopods scarcely evident. Telson unarmed, slightly asymmetrical.

COLOR: Specimens from "Combat" sta. 384 after one year In alcohol. Eyestalks orange vermillion. Lateral stripes of antennal slagellum scarlet vermillion. Shield and perelopods cream. 
MEASUREMENTS (mm.): Male from "Combat" sta. 384. Shleld, length 7.0 , widh 6.9 ; carapace 13.5 ; eyes 7.0 , chela, length 11.8 , width 6.5 , dactyl 8.0 , third pereiopod, basis-1sch1um 6.2 , merus 7.2 , carpus 5.8 , propodus 6.1 , dacty 11.9 .

\section{Paguristopsis n. gen.}

Type species: Pagur1stes humm1 Wass, 1955, p. 148. Differs from Paguristes in absence in females of an anterfor pair of pleopods and a complete lack of a brood pouch. Differs from Isocheles in presence of two anterior pairs of pleopods in males. First pair of male pleopods with numerous recurved hooks on outer distal margin.

Th1s genus is erected to include the type specles and Paguristes veddell1 (H. Milne Edvards), a specles found on the coasts of Chile and Peru, a specimen in the USM from the Gulf of Callfornia may also belong to the latter species.

\section{Paruristonsis bumm1 (Wass)}

Paguristes humm1 Wass, 1955, D. 148, P1gs. 1-4. MATERIAL BXAMIMED; Bighty specimens from Georg1a and the northern and eastern coasts of the Gulf of Mexico.

Holotype male, USIM 95596; Alligator Harbor, Franklin Co., Fla,; June 1, 1952; A. S. Pearse. Paratypes: 1 male in a sponge; Apr. 17, 1952, and 2 males in a single cavity of a 
sponge; May 10, 1952, Alligator Harbor; H. J. Humm. I male from a Nurex shell; Alligator Harbor; Apr. 4, 1953. 4 males, 1 female; Oct. 10, 1953; 25 males, 20 females (10 ovig.); oct. 16, 1954, tidepools at Mullet Key, Tampa Bay, Fla.; M. L. Wass.

Georg1a: $31^{\circ} 58^{\prime}$ N., $80^{\circ} 44^{\prime} W_{03} 6 \frac{t}{2}$ Ims.; Feb. 3, 1940, "Pelican" sta. 181-1; 1 female.

Texas: M_Cr 75, M-Cr 78, W. G. Hewatt; 2 males. Louisiana: $28^{\circ} 36^{\prime} \mathrm{N} ., 90^{\circ} 55^{\prime}$ W.; 10 fms.; Mar. 18, 1938; Peterson grab; "Pellcan" sta. 33; 1 male. Breton Is. Gosier Is.; July 18, 1935; "Pelican"; 1 male.

West coast of Floridas $29^{\circ} 28^{\prime} \mathrm{N} ., 85^{\circ} 31^{\prime} \mathrm{W}_{0}, 12 \mathrm{fms}, 3$ Feb. 1, 1956; "A. A. Jakkula"; 1 female in large bryozoan, Hipporidra edax Busk. Alligator Harbor: oct. 29, 1955, M. L. Wass, I male in a sponge; JuIy 7, 1957, H. J. Humm; I male in a shell nearly covered by a sponge. Sea Horse Key; Nov. 2, 1957; M. L. Wass; 1 male. Opposite Anclote River; Nov.-Dec., 1900, J. E. Benedict; I female in a sheli which also contained an annelid. Egmont Key, Fla,; W. Z. Coons; 3 males, 3 females ( 1 female regenerating both chelipeds), USNM 996 (date unknown). Mullet Key; Oct. 16, 1954; M. L. Wass; 7 males, 1 ovig. female (sent to Paris Museum). Lemon Bay, trawled In pass; Jan. 25, 1938; 01ga Hartman; 1 male, I female. Charlotte Harbor; 2 fms.; Feb., 1884; Henry Hemph111; 2 males, USNM 6664.

RANGE: Georg1a and nortern coast of Gulf of Mexico 
Prom Galveston, Texas to Charlotte Harbor, Fla.; probably not found on east coast of Florida or In the Keys.

DIAGNOSIS: Other than gener1c characters, antennal Plagellum short, with two rows of long, ventrolaterally drected setae, as in Isocheles. Eyes narrow, cornea not dilated; eye scales approximated.

DESCRIPTION, Shield longer than w1de; rostrum obso. lescent, exceeded by pointed lateral teeth. Eyes shorter than shleld; scales long, approximated, $11 \mathrm{ghtly}$ armed laterally. Antennular peduncle exceeding eyes by half of terminal segment; antennal peduncle exceeding slightly. Antennal flagellum subequal to chelipeds, setae in two ventral rows, each seta about half as long as flagellum.

Chelipeds equal, weak, articulating horizontally w1th carpus. Several strong spines on inner dorsal margin of carpus, propodus, and dactyl. Spines on outer margin smaller. Fingers meet only at tips. Fine pilose halrs appear on all perelopods, part1cularly on dorsal surfaces. Second perelopods feebly armed on dorsal angles of carpus and propodus. Walking legs easily exceed chelipeds.

F1rst pair of gonopods strong, well separated basally; second pair weak, not extending beyond first pair. Unpalr. ed pleopods of male uniramous. Terminal lobes of telson asymmetric, each armed with two corneous spinules.

COLOR: Only outstanding color mark a bright blue area bordered anterlorly by a black and a yellow band on inner 
surface of merus of chelipeds. Antennal flagellum pale blue. Dactyl of walking legs marked by two reddish bands. MEASUREMENTS (mm.), Shield, length 3.2, width 2.7; carapace 6.5; eyes 2.9; chela, length 4.6, width 2.5, dactyl 2.7; third right perelopod, basis_ischlum 1.8, merus 2.9. carpus 2.5, propodus 3.5, dactyl 5.0 .

REVARKS: This species is strikingly similar to $\mathrm{P}$. weddell1. The latter is several times larger in the adult. A male from San Juan Bay, Peru, Allan Hancock Foundation sta. 828_38, has a carapace length of $20 \mathrm{~mm}$. The most striking difference is in the telson; that of weddell1 has the small terminal lobes separated by the broad median plate, the margin of which is armed with 13 short, corneous spinules.

Other differences in weddell1 are the narrower cornea, the strongly angled claw on the dactyl of the walking legs, the more numerous callosities and setae under the thorax, and In the first pair of male pleopods. In weddell1 the latter have only 13 recurved spines on the distal margin and the arrangement of setae is quite alfferent.

\section{Petrochirus bahamensis (Herbst)}

Cancer maximus bahamensis Catesby, 1743, p. 34, p1. 34. Cancer bahamensis Herbst, 1791, p. 30. Paqurus granulatus 01ivier, 1811, p. 640. 
Petrochirus Exanulatus Stimpson, 1858, p. 233. -Rankin, 1910, p. 82. _-Gordan, 1956, p. 339.

Petrochirus bahamensis Rathbun, 1897, p. 42. -Boone, 1925, p. 76, 1930, p. 21, pl. 1; 81938, p. 261. -H11debrande, 1954, p. 271, 326, 1958, p. 259.

MATERIAL EXAMINED, Thirty-six specimens from the coasts of elght states and countries.

Texas: Off Port Aransas; Apr11 28, 1948; J. W. Hedgpeth; 2 males. Thirty m1. north of Port Isabel, $17.20 \mathrm{fms} . ;$ Nov. 16_18, 1950; H. H. Hlldebrand, 1 female, off Port Isabel; Mar. 30, 1947; $9.10 \mathrm{fms}$; J. W. Hedgpeth; 1 male, 5 females. $28^{\circ} 48^{\prime} \mathrm{N}_{0}, 94^{\circ} 39^{\prime} \mathrm{W}_{.3} 11 \mathrm{fms.3}$ May 5, 1938, "Pellcan" sta. 60-3, 1 male. $29^{\circ} 00^{\prime} \mathrm{N}, ., 94^{\circ} 38^{\prime} \mathrm{W}_{. ;} 8 \mathrm{fms.3}$ Jan. 21, 1939; "Pelican" sta. 104-5; 1 juv, female.

Loulsiang: $29^{\circ} 20^{\prime} \mathrm{N} ., 88^{\circ} 17^{\prime} \mathrm{W}$.; 33 fms. Feb. 5 , 1938, "Pelican" sta. 13,1 male. $29^{\circ} 06^{\prime} \mathrm{N} ., 92^{\circ} 16^{\prime} \mathrm{W}_{0} 3$ 8.5 fms.; May 10, 1938, "Pelican" sta. 65-10; 1 Juv, Semale. $29^{\circ} 10^{\prime} \mathrm{N}_{.}, 93^{\circ} 23^{\prime} \mathrm{W}_{.} 9$ fms.; May 10, 1938, "Pelican" sta. $64-4,1$ juv, male.

Mississioni: Sh1p Is.; June, 1941; R. J. Miller; 1 male, MCZ 11941, carapace length $52 \mathrm{~mm}$.

Florida (west coast): Panama C1ty; 12 Ims.; Oct. 13, 1956; G. D. Grice; 1 male, carapace length $54^{\mathrm{mm} .} 29^{\circ} 07^{\prime} \mathrm{N} ., 85^{\circ} 40^{\prime}$ W.3 50 fms.; Mar. 10, 1939; "Pel1can" sta. 154-3; 1 male, carapace length $70 \mathrm{~mm}, 29^{\circ} 25^{\prime} \mathrm{N} ., 8^{\circ} 56^{\prime} \mathrm{W} ., 13$ Pms.; Feb. 10, 1957; "Oregon" sta. 1674; 1 juv, male. Hog Is. Keg; 


\section{2.}

Sept. 7, 1938, "Pellcan" launch, I male. Sarasota, LIdo Beach; Feb. 15, 1957; J. Vaughn, 1 male. Sanibel Is, ; March, 1938; 1 male, 2 females, MCZ 10156.

Tortugas: $40 \mathrm{fms.;}$ Aug. 4, 1931; Murex she11; W. L. Schmitt; I female. BIrd Key Reef; July, 1931; W. L. Schmitt, 1 male, carapace length $55 \mathrm{~mm}$. Fort Jefferson; July, 1930; W. L. Schmitt; 1 male, carapace length $65 \mathrm{~mm}$. Off Jacksonville: $30^{\circ} 28^{\prime} \mathrm{N} ., 80^{\circ} 48^{\prime} \mathrm{W}_{.3} 15 \mathrm{fms.3}$ Jan. 26, 1940, "Pelican" sta. 176-7, 1 female.

Jupiter Inlet: $\mathrm{m1}$. north in Indian River, June 22, 1957, J. Yount and J. Flora, 2 males, carapace lengths 57 and $63 \mathrm{~mm}$.

Iucatan: $20 \mathrm{ml}$. northwest of Campeche, Feb. 7, 1951; H. Н. HIldebrand; 3 males. Golfo de Campeche; Pedro Fuentes, 2 males, MCZ 12332.

Cube: Havana; Jan. 8, 1937; L. Howell Rivero, 1 male, MCZ 9743, earapace length $53 \mathrm{~mm} .20^{\circ} 03^{\prime} \mathrm{N}_{0}, 77^{\circ} 55^{\prime} \mathrm{W}$, 13 fms.3 Apr. 9, 1939, "Atlantis" sta. 3347, 1 male.

Surinam: $06^{\circ} 30^{\prime} \mathrm{N} ., 55^{\circ} 52^{\prime} \mathrm{W}$ : $17 \mathrm{fms.s}$ Sept. 3, 1958, "Oregon" sta. 2272, I remale.

ofe mouth of Amazon: $02^{\circ} 31^{\prime} \mathrm{N} ., 48^{\circ} 48^{\prime} \mathrm{W}_{0}, 55-60$ Ims.; Nov, 15, 1957; "Oregon" sta. 2061; 1 semale.

RANGE: Beaufort, N.C., to Rio de Jane1ro; Intertidal to at least $55 \mathrm{fms}$.

DIAGNOSIS: Largest hermit crab in western Atlantic. Adults usually in shells of Strombus and Busreon. Right 
chela noticably larger than left. Chelipeds nude except for minute fringe of pubescence on scalloped tubercles of chelae.

DESCRIPTION: Shleld relatively small, Plattened. Rostrum supporting several stiff setae, equaling lateral teeth. Remainder of carapace large, membranous. Eyes slightly exceeding shield in young, subequal in large specimens. Eye scales small, terminating in a small spine. Antennular peduncle equaling eyes; that of antenna shorter. Acicle small, with two minute spinules on inner edge. Flagellum equaling perelopods.

Chelipeds moderately armed, similar. Chela covered with scale-like tubercles; each tubercle Iringed with minute, pubescent setac as in Dardanus venosus. Cutting edges similar in both chelae, tips calcareous on major member, corneous on minor. Walking legs unarmed, densely setose in rows along dorsal, ventral, and Inner surfaces; claw short, stout.

Fourth perelopod 1mperfectly chelate; pollex portion of propodus covered ventrolaterally with rasp of minute scales. Propodus of flfth palr chelate, rasp on distal half. Male pleopods uniramous. Telson short, asymetrie; fine setae and spinules on margin.

COLOR, Reddish color of chelipeds and walking legs becomes darker distally. Pubescent fringes of tubercles uniformly dark red. In 11fe, bright purple colors are on 
sides of antennular and antennal peduncles.

MEASUREMENTS (mm.): Male from Sarasota, Fla.: Shield, length 34 , width 32 ; carapace 68; eyes 29; major chela, length 73, width 38, dactyl 45; minor chela, length 66; th1rd right perelopod, basis_ischium 21, merus 31, carpus 30 , propodus 30 , dacty 155.

REMARKS: The male from Sarasota weighed $400 \mathrm{gms}$, and was taken from a Busrcon shell welghing 595 gms., while the Juvenile male from "Oregon" sta. 1674 welghed 0.36 gms, and was found in a bryozoan, Hipooporidra edax Busk, which we1ghed $18.5 \mathrm{gms}$, about 50 times as much.

The relative sizes of the chelae are usually not great. ly different but in four chelae measured, the length of the left member ranged from 66 to $90 \%$ of that of the right. 


\section{Fam1ly Paguridae Latre1lle}

Shield of carapace usually longer than broad; rostrum obsolescent, rarely covering ophthalmic somite. G11l covers usually membranous, if calcifled anterlorly surface is broken Into numerous plates.

Eyes usually shorter than shield and more or less di. lated at cornea. Eye scales usually simple at tips. An. tennular peduncles usually exceeding eyes; those of an tennae less often doing so. Latter rarely well armed; fla. gellum usually longer than carapace and nude or nearly so.

External maxillipeds widely separated by a sternum; latter often with a median suture flanked by a denticle on each side.

Gill pairs 11 or 13 except in Octopagurus, which has elght; lamellae usually biseriate, quadriseriate in three genera.

Right cheliped more or less enlarged, never smaller than left. Chela articulating vertically with carpus. Cutting edges of wajor chela present calcareous teeth of varying sizes; those of minor chela composed of fine corne. ous teeth supported by minute calcareous ones. Walking legs usually slender, elongated; those on right a little longer. Dactyls often twisted in deep_water forms.

Vas deferens protruding in seven genera. Gonopods never 


\section{6.}

present in both genera; two pairs found in males of four genera, one pair in males of three genera and females of 11ve genera, A single genus (Pagurodes) has the vas defer. ens protruding in the male and the female with a pair of gonopods, No genera have the male with gonopods and a protruding vas deferens.

Abdomen usually twisted and presenting three or four unpaired pleopods in males. Parapagurus and Mun1donagurus have the abdomen much reduced and solded beneath the thorax. Four genera have males lacking unpaired pleopods. Telson and uropods asymetric in most genera. Telson generally deeply eleft distally.

This family contains very few reef_dwelling forms but the genus Pagurus contains most cold_water pagurids. It also has a large number of genera and specles found on the lower part of the shelf or at greater depths.

\section{Key to Genera}

1. Male w1th vas deferens protruding on one or both........

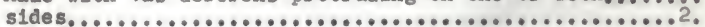

Vas deferens never protruding......................

2. Vas deferens protruding on only one side................ Vas deferens protruding on both sldes, the right end. Ing in a long filament................. Nematonagurus.

3. Only right vas deferens normally protruding..........4. Only left vas deferens normally protruding...........6. 
4. Female with a pair of anterlor abdominal appendages.....

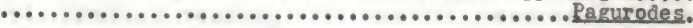

Female lacking palred anterior abdominal appendages...5.

5. R1ght vas deferens recurves over right flank of ab. domen; four unpaired pleopods in both sexes. Catapagurus. Right vas deferens crossing beneath abdomen or extend.

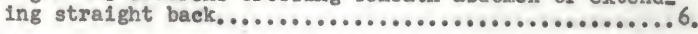

6. Right vas deferens sabre_shaped............. Right vas deferens extending straight back or crossing under abdomen and up left side................estopagurus.

7. Left vas deferens colled in a spiral, right cheliped not much larger than left................ Splropegurus.

Left vas deferens only curved, right cheliped much

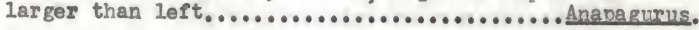

8. Paired anterior pleopods present in e1ther male or female but not in both.............................

Palred anterior pleopods absent in both sexes.........19.

9. Paired anter1or pleopods present in male only.......10. Palred anterior pleopods present in female only......16. 10. Two pairs of pleopods present...................... Paired pleopods present on flrst segment only.......14.

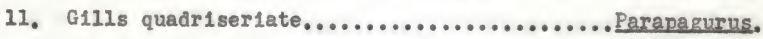

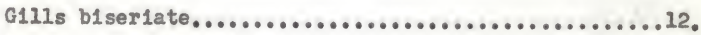
12.. Rostrum obsolescent, abdomem twisted......... Sympagurus. Rostrum prominent, abdomen stra1ght.................3.

13. Paired pleopods of male followed by three unpaired...... .................................... Trlasnis.

Male lacking unpalred pleopods.............Xrlopagurus. 14. G111 palrs 11......................... Tomonagurus.

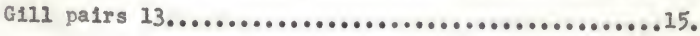


15. Male with paired pleopods followed by four unpalred; gills biseriate..................... Tomopaguropsis.

Male with paired pleopods followed by three unpaired, g111s quadriseriate.................. Tomopagureldes.

16. Gill palrs 11..................................

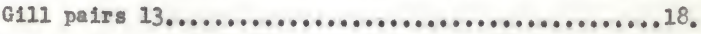

17. Right chela forming an operculum by itself andor covered with spinous or sculptured tubercles............. .........................................

Right chela not forming an operculum by itself and never presenting sculptured tubercles...... Ceratopagurus.

18. Three unpaired pleopods present in male..Pylopaguronsis. Pleopods lacking in male.................unldopagurus.

19. Eggs carried dorsally............... Porcellanonagurus. Eggs carried normally........................20.

20. Gill pairs elght, eye scales with four or f1ve terminal spines............................... . ctonagurus. G1II palrs more than elght, eye scales simple........21.

21. Abdomen tw1sted, telson and uropods asymmetrical.....22. Abdomen straight, telson and uropods subsymmetrical..23.

22. Male with three or, rarely, four unpaired pleopods......

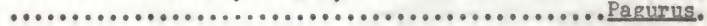

Male lacking paired pleopods................... Paguritta.

23. Abdomen extremely reduced, carapace calcified through. out................................ ostraconotus.

Abdomen elongate, not particularly reduced, carapace not ent1rely calcisled...........................24.

24. Male with three unpaired pleopods........... Orthongarus. Male lacking unpaired pleopods.......... Orthonaguronsis. 


\section{Genus Anapagurus Henderson}

DIAGNosIs: (After Milne Edwards and Bouvler, 1893) Chelipeds dissim1lar; right short, chela larger and more regularly oval than in Splropagurus. Left chela similar to that of Pylopagurus, always much more slender and com. pressed than right chela.

G111 pairs 11; lamellae biflô, phyllobranchlate. Sexual tube a simple are. Fourth perelopods not subchelate (as was reported by MIIne Edwards and Bouvier); propodal rasp uniserlate. Fifth perelopods subchelate. Left vas deferens short, not forming a complete circle.

\section{Key to Species}

Minor cheliped with two dorsal rows of sharp denticles on carpus; a single dorsal row on propodus........... acutus.

Minor cheliped unarmed except for two spines on distal margin of carpus, one on merus................marginatus.

No specimens have been taken of these two species since they were described. Type material is at the MCZ.

\section{Anapagurus scutus Milne Edwards and Bouvier}

Anapagurus acutus M1Ine Bdwards and Bouv1er, 1893, p. 120, p1. 9, 11gs. 7-13. -Gordan, 1956, p. 302.

RANGE; Type local1ty, of Key West. $24^{\circ} 15^{\prime} \mathrm{N}, 82^{\circ} 13^{\prime}$ 
W.; 152-229 Ims,

DIAGNOSIS: (After Milne Edwards and Bouvier) Shleld longer than cardiac plate. Lateral teeth short but acuml. nate; rostrum obtuse. Eyes dilated at cornea, much shorter than frontal margln; stalks sparsely setose above. Eye scales one_fourth as long as eyestalks.

Rlght cheliped large, chela equal to comblned length of merus and carpus, Outer margin of pollex much straight. er than that of pelm; margins of chele finely denticulate. Carpus of minor chela concave above with a row of spinules on either side. Palm of chela with a dorsal row of sharp spinules; fingers much longer than pelm.

\section{Anapagurus marginatus M1Ine Edwards and Bouvier}

Anapagurus marsinatus M1Ine Edwards and Bouvier, 1893, p. 123, p1. 9, 11gs, 14_18. _-Gordan, 1956, p. 303.

RANGE: Type locality, Barbados, 73 fms.

DIAGNOSIS: (After Milne Edwards and Bouvier) Anter1or projections of shleld subequel, obtuse. Eyestalks a little shorter than the frontal marg1n. Antennal acicle slender and curved outward, Plagellum long and nude.

Right cheliped wuch larger and stronger than left. Carpus and chela completely unarmed, margins of chela narrow. Left cheliped slender, unarmed except on merus and carpus. 
Catapaguroldes microos M1Ine Edwards and Bouvier

Catapaguroides mlerons Milne Edwards and Bouvier, 1892, p. 211. _-Gordan, 1956, p. 306.

MATERIAL EXAMINED; Two males from Cuba, $20^{\circ} 49^{\prime} \mathrm{N}$, $75^{\circ} 08$ ' W.3 600 fms.; Apr. 20, 1939, "Atlantis" sta. 3369, 1 male. $21^{\circ} 49^{\prime} \mathrm{N} ., 76^{\circ} 43^{\prime} \mathrm{W}$; 910 Ims.; Apr. 25, 1939; "Atlant1s" sta. 3379; 1 male.

RANGE; In eastern Atlant1c, off northwestern coast of Spain to Azores and Morocco; 524 to $1540 \mathrm{fms.} \mathrm{In} \mathrm{western}$ Atlant1c, Cuba, north of Orlente province; 600 to $910 \mathrm{fms}$.

DIAGNOSIS: Walking legs longex than body; eyes with cornea much reduced. R1ght vas deferens short, sabreshaped.

DESCRIPTION: Shield convex, smooth, with few setae. Rostrum rounded, slightly exceeding lateral teeth. Cardiac plate widest poster1orly; g11l cover membranous, expanded.

Eyes half as long as shield, narrowed distally, cornea plgmented but small, a few anterodorsal setae on stalk directed forward beyond cornea. Antennular peduncle exceeds eyes by last two segments; terminal segment equals length of shield. Second segment of antennal peduncle spined only on outer angle; aclcle exceeds eye by $2 / 3$; peduncle by $1 \frac{1}{2}$ segments. Flagellum equaling logs; feebly setose at each articulation.

Right chelipod larger and slightly longer than left. 
Chelipeds w1th rinute spines only on anteroventral angles. Major chela presents three broad teeth on dactyl meshing with two similar ones on pollex. Cutting edges of minor chela meet along entire surface; edges formed of minute, corneous teeth.

Walking legs very long; dactyls partlcularly long and laterally compressed; latter with several strong setae forming a distal, double-rowed comb reaching beyond dactylar tips. Second perelopods bear a long, recurved spine $(0.8 \mathrm{~mm}$.$) on distoventral margin of propoaus; spine$ touching dactyl when latter is reflexed at an angle less than 100 degrees. Four progressively shorter, setose spines appear on elther side above longer spine. Dactylar claws reduced; color same as that of setae. Narrow plate between third pair of perelopods presents a comb of short setae.

Propodus of fourth perelopods with a uniseriate rasp on the distal t reefifths of ventral margin, with stout dactyl continuing this rasp to the sharp claw. Fifth pair subchelate, with a hoof-shaped dactyl meeting a blunt pollex. Propodus bears tuft of long ha1r on lower margin adjacent to feeble rasp on outer, distal half. Vas deferens stout, with shape of broad trough extending somewhat diagonally across opposite coxa and curving forward. Basket-like tuft of long hair projects forward from sternal plate beneath vas deferens. Telson deeply cleft distally; I1ghtly armed. 
MEASUREIENTS (mm.): Holotype male; shield, length 2.2, width 2.2, carapace length 3.8, eyes 1.1; major chela, length 3.6, width 1.3, dacty1 1.6, third perelopod, basisisch1um 1.9, merus 3.0 , carpus 2.2, propodus 3.3 , dactyl 5.4 .

REMARKS: The long dactyls of the walking legs appear to be carried bent beneath the an1mal, with the propodal spine lending support and the long setae acting as a snowshoe on muddy bottoms. This genus and the species have previously been known only from the eastern Atlantic and Mediterranean.

\section{Genus Catanagurus A. M1Ine Edwards}

DIAGNOSIS: (After Milne Edwards and Bouvier, 1893).

Shleld well calcleled, broad, short; with lateral pro. jection of margin longer than median. Eyes very short, dllated at cornea. Eye scales well separated, usually long. Antennal flagellum long, nude or nearly so.

First pair of maxillae lacking a palp. G111 pairs 13; formed of two rows of large lamellae.

Right chellped usually much larger than left. Walking legs slender, rather feeble. Fourth perelopods, described as more or less subchelate, can scarcely be so termed, rasp a single row of denticles. Fifth pair not chelate, but with a well developed rasp. 


\section{4.}

Male with vas deferens protruding from right slde and recurved over right flank. Abdomen twisted and reduced. Male with four unpaired pleopods, each small and uniramous. Female with three egg-bearing pleopods biramous, fourth 11ke that of male.

Key to Species

1. Cornea greatly dilated; shleld broader than long....... sharrer 1.

Cornea little dilated; width of shield subegnal to length......................................111s.

\section{Catanagurus grac111s (Smith)}

Heminagurus erac111s Smith, 1881, p. 426.

Catanagurus grac111s Sm1th, 1883, p. 33. _-Gordan, 1956, p. 306 .

RANGE: Nassachusetts to Barbados; 53 to 155 fms.

DIAGNOSIS: (APter Milne Edwards and Bouvier, 1893). Eye scales much more elongate than in sharrer1, considerably surpassing mlddle of eye stalks. Eyes two-thlrds length of Irontal wargin of shleld. Antennular peduncles exceed eyes by terminal seguent; those of antennae exceed by half of last segment. Acicle slender, recurved. Flagellum presents several long setae.

Right cheliped much longer and stronger than left. Differs from that of sharrer1 as follows: Much more slender, 
carpus with a row of fine denticles above; chela more finely granular, much longer and stralghter, lacking clear IInes, and with an indentation in propodus at base of dactyl. Left limb attaining middle of chela of right; very slender and with two rows of elne denticles dorsally on carpus.

Walking legs much more slender than in sharrer1; dactyls very long. Last two segments of third perelopods much longer than in second pair.

M1Ine Edwards and Bouvier (1893) also proposed a varlety, longimanus, for forms with the major chela especial. Iy long and slender, and gave a detalled deseription of the varlety 1ntermedius which was characterized malnly by the chelae being much shorter and more oval in shape.

\section{Catapagurus sharrer1 A. M1lne Edwards}

Catapagurus sharrer1 A. M1Ine Edwards, 1880 , p. 46. --Gordan, 1956, p. 307.

Heminagurus socialis Sm1th, 1881, p. 423.

Catapagurus socla11s Sm1th, 1882, p. 16.

MATERIAL EXAMINED: Holotype male; Barbados; "Blake" sta. 299.

Cuba: North of Orlente province, $20^{\circ} 46^{\prime} \mathrm{N} ., 75^{\circ} 13^{\prime}$ W.; 295 fms.; Apr. 20, 1939; "Atlant1s " sta. 3371; I ovig. female.

RANGE: Massachusetts to Barbados; 53 to 264 fms. 
DIAGNOSIS: (After M11ne Edwards and Bouvier, 1893). Shleld broader than long, flnely setose except in center; gastric region with two lobes anteriorly. Cardiac plate short and narrow. Eyes very short, cornea greatly dilated, reaching middle of penultimate segment of antennular peduncle. Peduncle of antennae exceeding eyes by terminal segment; aclele exceeding by nearly half of length.

Comparisons of perelopods have been given in the diagnosis of C. gracilis.

Genus Ceratopagurus Yokoya

Ceratonagurus cubensis $n$. sp.

MATERIAL EXAMINED; Holotype female, MCZ 126682; $23^{\circ}$ $10^{\prime} N_{*}, 81^{\circ}$ '2' W.; 200 Pms.; May 11, 1939; "Atlant1s" sta. 3480 .

RANGE: North of Matanzas Province, Cuba; known only type.

DIAGNOSIS: General appearance typical of genus Pagurus. Chellpeds armed dorsally with numerous splnes. Eyes large, swollen distally. Abdomen reduced, a small palr of anterior pleopods present.

DESCRIPTION: Shield glossy; a transverse tuft of setae behind rostrum and each lateral tooth; a line of three punctae with short setae on e1ther side of gastric region. Frontal margin ralsed between lateral teeth. Rostrum rounded, equal 
to lateral teeth; latter each t1pped with a minute spinule. Shleld projects submarglnally from lateral teeth toward eye scales. A long, narrow plate slanks posterolateral edge of shleld on elther side. Cardiac plate narrow, widest in back; rectangular caleifled areas flank this plate in front. G11l covers membranous, pitting closely over gills. Eyes short, greatly expanded distally. Eye scales broad, with ralsed edges; tip rounded, with minute subapical spinule. Antennular peduncle short, exceeding eyes by one-third of terminal segment. Antennal peduncle with a minute, subbasal spinule on outer edge. Second segment with external prolongation reaching almost to level of cornea; both angles spine_tipped; terminal segment reaching same level as that of antennular peduncle. Aclele curved outward, spine-tipped, exceeding cornea. Flagellum nude; not reaching tips of legs.

Major cheliped with four sharp spines on anterodorsal margin of merus, three short spines on outer, anteroventral angle. A few tubercles appear on ventralmost part of merus of each cheliped. Carpus and propodus similarly armed on upper surface with numerous spines in somewhat irregular rows; strongest spines on inner edge. Fingers grooved slightly on upper surface. Dorsal ridge runs forward on finger from ar. ticulating socket, with a strong, adjacent spine proximally. Fingers close only on distal third of gape; teeth low, irregu. lar. 


\section{8.}

Minor cheliped slightly shorter than mafor but appearing longer because of body torsion. Armament similar to that of larger cheliped, with three anterodorsal spines on merus. Fingers meeting throughout gape; cutting edges of Iine, corneous teeth, interspersed on pollex with several minute, calcareous teeth. Setae sparse on both chelipeds.

Second pair of perelopods with dorsal row of elght spines on merus, eight_ten small spines or denticles on propodus. Third perelopods also with elght spines on carpus, but only spinules on propodus. Dactyl of both walking legs with a longltudinal groove on median outer surface. Spinu. lose setae on distal half of Inner dorsal surface of dactyl increase in size and number toward straight, corneous tip.

Propodus of fourth perelopods presents a curved row of over 20 scales on ventral edge while stout dactyl has a row of about 10 very minute scales. Blunt, calcareous tooth appears above terminus of dactylar rasp; recurved, corneous claw rises dorsomedially to this tooth. Propodus of ifth perelopods elongate, chelate, and with a rasp on slightly more than distal half. Ventral edge bears a brush of long, Iine setae.

Paired female appendages flat; distal segment slightly spatulate, total length $1.7 \mathrm{~mm}$. End of abdomen missing. A mass of approximately 1,000 eggs, 0.7 mm. in diameter, covers remaining portion of abdomen.

COLOR: After 19 years in alcohol, an orange_red hue of 
varying intensity occurs at the following polnts: Shleld, a short distance behind rostrum; eyestalks, increasing in Intensity toward black cornea, distally on dorsal and lateral margins of merus of first three perelopods, carpus of walking legs in a long1tudinal band on ventrolateral surface; a narrow median stripe on outer surface of propodus, continued in groove of dactyl, a faded stripe on inner surface of merus of second perelopods.

MEASUREMENTS (mm.): Shleld, length 7.0, w1dth 7.1, carapace length 12.0 , eyes 5.5 ; major chela, length 13.4 , w1dth 6.2 , einger 7.0 , minor chela, length 11.0 , width 3.6 ; third leg, basis-1sch1um 5.7, merus 8.5 , carpus 5.8 , propodus 8.0 , dactyls 14.0 .

REMARKS, This species is provisionally placed in the genus Ceratonagurus. The only characters which it has in common with Prlopagurus are palred anterlor pleopods in the fomale and 11 pairs of g1lls. The specles can be properly placed only when a male is taken and when the genus Ceratopagurus is more completely described.

Genus Cestopagurus Bouvier

\section{Cestonagurus Iineatus}

MATERIAL EXAMINED: Holotype male, allotype female, s1x paratypes (five males and one female), $07^{\circ} 25^{\prime} \mathrm{N} ., 54^{\circ} 35^{\prime}$ W.; 75-80 fms.3 Sept. 8, 1958, "Oregon" sta. 2289. 


\section{0.}

RANGE: Type locality, off Surinam.

DIAGNOSIS; Vas deferens extends straight back for half of length of abdomen. First three pereiopods dell. cately striped. Chelae covered with plumose halrs. Fla. gellum long, Pllamentous.

DESCRIPTION: Shleld smooth, with a few setose tufts. Obsolescent rostrum slightly exceeding lateral teeth. Eyes swollen slightly near base and at cornea. S1x tufts of setae on eyestalk, distalmost extending over cornea. Eye scales small, concave and narrow; subapical splnule set low. Antennular peduncle exceeds eyes by half of terminal segment. Antennal peduncle and acicle slightly exceed eye. Flagellum long, exceeding perelopods by half their length. Right chela similar to and little longer than left. Both chelipeds with numerous stiff setae, except on chelae, whlch have exposed surfaces covered with fine, plumose hairs. Carp1 and chelae of both chellpeds armed on inner dorsal margins with spinules. Carpi also have two rows of minute spinules near outer dorsal angle. Cutting edges similar on both chelae, those of right member with less sharp edges. Dactyls of both have corneous teeth on less than half of distal edge. Calcareous teeth on remaining edges small.

Walking legs with numerous simple setae, becoming p1lose on propodus and dactyl of flrst leg on left side. Carp1 with a distodorsal spinule. Dactyls with ventral row of strong corneous spinules. Fourth perelopods only 
feebly chelate; propodal rasp uniseriate. Subchelate fifth propodus with rasp on little more than distal half.

Sternal plate separating th1rd maxillipeds lacking spinules and median suture. Vas deferens straight, conlcal, at least half as long as ventral surface of abdomen. Male pleopods feebly biramous. Telson small, minutely serrate on margins of median cleft.

COLOR: First three pairs of perelopods longltudinally striped with fine coral lines. Last four segments of each perelopod with scarlet thickenings of regular stripes mid. way, except more proximally on dactyls of second and third palrs; represented on chelae only by a small inner spot. Fead appendages banded at base of eye scales, at each end and midway on eye stalks with irregular blotches of coral. An. tennular peduncles with a rose purple band on each of f1rst two segments, two on last segment.

MEASUREMENTS (mm.): Male holotype. Shleld, length 4.0, width 4.2 ; carapace 7.0 , eyes 3.7 ; right chela, length 6.7 , width 2.5, dactyl 3.2; third right perelopod, basis_1sch1um 2.9 , merus 5.5 , carpus 3.6 , propodus 5.7 , dactyl 7.7 .

Genus Munidopagurus A. Milne Edwards

Munidonagurus macrocheles (A. M1lne Edwards)

Eupagurus pacrocheles A. M1lne Edwards, 1880, p. 40. Munidopagurus macrocheles Milne Edwards and Bouvier, 
1893, p. 103, pl. 7, 11gs. 21_26.

MATERIAI, EXANINED; Three specimens from Cuba. Holotype ferale; of Havana; 175 fms.; "Blake". Cuba, Bahia de Coch1nos; $22^{\circ} 13^{\prime} \pi ., 81^{\circ} 11^{\prime} \mathrm{W}_{\text {. }} 185$ Ims.; Apr. 4, 1939, "Atlantis" sta. 3320, 1 male. Old Bahama Channel, north of Camaguey Province; $22^{\circ} 32^{\prime} \mathrm{N} ., 78^{\circ}$ 08 ' W.; 220 fms.; Apr. 27, 1939; "Atlant1s" sta. 3389; 1 male.

RANGE; Cuba; 175 to 220 fms.

DIAGNOSIS: Body short, abdomen much reduced. Chellpeds equal, narrow, twlce as long as body, well armed. DESCRIPTION: Shleld glossy, very convex, with fine setae at four points on each side, one next to rostrum and three in row behind lateral tooth. Rostrum very strong, forming conical spine above level of lateral teeth and exceeding ophthalmic ring. Frontal margin meeting beneath rostrum, ralsed between lateral teeth. Cardac plate very short, In shape of an inverted bell; rounded plate on elther side bears a prominent tuft of setae.

Eyes short, half as long as shleld, moderately swollen distally. Eye scales form long, narrow spines. Antennular peduncle narrow, exceeding eyes by terminal segment. An. tennal peduncle exceeds eyes by slightly more than terminal segment; second segment with short spine on Inner angle, outer angle setose, not markedly produced; third segment with a spinule on ventral projection. Aclele long, narrow, 
unarmed, exceeding eye by one-half. Flagellum nearly reach. Ing tip of najor chela; sparsely setose.

Major cheliped normally exceeding minor. Merus plat, concave ventrally, up to 15 strong spines on outer margin, less on Inner; spines small and numerous on distal ends of margins. Dorsal surface of merus above ventrolateral margins bears nuwerous combs of long setae rising from fineIy dentate escarpments. Carpus th1ckly set with spines on dorsolateral surface and on Inner dorsal and ventral margins. A bare, depressed area on dorsal surface along inner row of spines. Chela presents numerous denticles of varying prominence dorsally. A 'single strong row of spines on outer margin to end of pollex. Inner margin of hand with a less even row of spines Planked by smaller ones; dactyl presents similar row of low spines and denticles. Fingers closing poorly, eutting edges present teeth apparently adapt. ed for holding; pollex with a strong, finely dentate ridge proximally which terminates in a strong tooth midway. At least 15 low teeth appear along remaining edge. Dactyl with seven teeth on proximal half, evenly decreasing in size distally; distal half with large teeth at three-fifths of distance from apex of eutting edges and at tip of fingers; IIne, corneous teeth in intervening gape.

Minor cheliped similar to major; more slender and with sharper spines. Chela with margins of slender splnes which disappear distally on P1ngers. Dorsal surface of palm with 


\section{4.}

two rows of short spines and tubercles which converge at apex of cutting edges. Latter finely serrate, calcareous proximally, corneous distally, w1th many calcareous teeth interspersed distally on pollex.

Walking legs compressed from coxa forward. Prominent setae on ventral margins of 1 schlum and merus, and on dorsal margins of carpus and propodus. Dactyl armed with corneous spinules on upper and lower margins.

Fourth perelopods long, compressed; lacking a rasp. Dorsal surfaces of three distal segments densely setose; a prominent tuft on distoventral surface of propodus. Long dactyl slightly upturned at t1p, with a minute claw. Long, subchelate propodus of elfth perelopods with a rasp on distal one-fifth and on part of dactyl; fringe of long setae on ventral margin.

Sternal plate separating third maxillipeds presents a median cleft bordered on each side by a strong spine. Male with long tufts of halr bordering coxal openings posterlorly and on intervening sternal segment.

Male abdomen extremely reduced, length about equal to that of thoracic reglon; flattened to fold under thorax. All pleopods absent in male. Telson and uropods quite symmetrical; exopod with a rasp on distal three-fifths of dorsal margin; endopod reduced to a strong, curved spine; a second stout spine appears at base of this spine. S1xth abdominal segment with a short spine at each posterolateral 
angle. Telson unarmed.

MEASURBMEITS (mm.): Shleld, length 14.6, w1dth 14.7; carapace length 17.5 ; eyes 5.8 , major cheliped, merus 25.0 , carpus 25, chela length 46, width 12.5, einger 17.4, third r1ght perelopod, basis-ischium 6.0, merus 15.8, carpus 10.0, propodus 14.0 , dactyl 18.5 .

REMARKS: Milne Edwards and Bouvler described the genus Yunidopagurus from a single female specimen. The two males taken by the "Atlantis" give further evidence of the aberrantness of th1s unusual genus. The reduced and platten. ed abdomen Indicate that this species may carry a commensal anemone over 1ts posterior parts. The female type specimen 1s less well armed on the chelipeds than are the two males. Nelther of the males has a perfect set of chelipeds. The large specimen from sta. 3389 is lacking the minor cheliped, While the smaller male from sta. 3320 has the larger one not fully regenerated.

Octopagurus gen. nov.

Type spec1es: Eupagurus premaeus Bouvier, 1918, p. 11. Differs from genus paqurus princlpally in presence of only elght pairs of gills Instead of 11. No other member of the Paguridae has less than 11 pairs. G11ls are phyllo. branchiate.

Bye scales broad, quadrate, with flve spines on distal 
margin whereas Pagurus species from western Atlantic have a single subapical spine on the eye scale. Third maxillipeds widely separated by a sternum bearing a median setose projection. This projection is lacking in the species of Pagurus examined.

Chellpeds well-armed, not markedly unequal; minor chela with eutting edges as in Pagurus.

Telson subsymmetrical; distal lobes separated and armed in a manner similar to that of eye scales.

Octopagurus prgmaeus (Bouvier) n. comb.

Eupazurus promeeus Bouvier, 1918, p. 11.

Pagurus premaeus Gordan, 1956, p. 335.

MATERIAL EXAMINED: Fourteen specimens from $s 1 x$ areas. South Carolina: 7 miles off Little River Inlet; Aug. 17. 1949, A. S. Pearse, 2 ovig. females.

Oef llorthwest Florida: Panama C1ty, 50-70 feet, Oct. 13, 1956, G. D. Grice, 1 ovig, female, $29^{\circ} 16^{\prime} \mathrm{N}, 85^{\circ} 32^{\prime}$ W. 26 fms.; Feb. 7, 1885, "Albatross" sta. 2369, 1 male. South Flor1da: off B1scayne Key; 16-34 feet, May 19, 1912; Paul Bartsch; 1 male. Tortugas; 80-150 fms, June 26, 1931; W. L. Schm1tt; 1 male. Tortugas; 45 fms.; July 22 , 1924; W. L. Schmitt; 1 ovig. female. South of Tortugas; 35 fms.; Aug. 14, 1933; Н. H. Darby; 1 male.

Cuba: On reer rlat between Cayo Hutla and Littlo Cayo; Henderson and Bartsch; I male, I female. Between Cape San 
Antonio and Cape Cagon; June 7, 1914, Henderson and Bartsch; 2 ovig. females.

Puerto Rico: Ponce; Jan, 30, 1899, "Fish Hawk"; 1 Juv. Trinidad: Carenage; Aug. 23, 1937, E. Deichmann; I male. RANGE\& South Carolina to Trinidad; shallow water to at least 80 fms.

DIAGNOSIS; Small specles; legs long1tudinally striped. Eyes long, slender, stalks narrowed between base and cornea. DESCRIPTION: Shield triangulate, well rounded at lateral angles. Rostrum obsolescent but equaling lateral teeth. Cardiac plate broad, bifurcate posteriorly. Eyes shorter than width of shield, swollen at cornea and base. Eye scales broad, with live spines on oblique, distal margin of each. Bases separated but Inner spines may meet at tips. Antennular peduncle slightly exceeding eye. Antennal pe. duncle subequal to eyes; second segment with denticle on Inner angle, two or three spinules at apex of outer project. 1on. Acicle slender, setose. Flagellum equaling pere1. opods.

Chelipeds normal. Carpus of major chellped armed with a few lateral and distal spines. Chela armed with several short spines on Inner margins of propodus and dactyl, with about 15 vertically pointing spines on outer margin. Dorsal surface with two rows of median spinules. Cutting edges with small, even teeth on pollex, corneous teeth on outer third of 


\section{8.}

dactyl. Minor cheliped with two spinules on inner ventral angle of merus, four on outer. Carpus with several strong lateral and distal spines. Marginal spinules of chela obscured by fine, thick setae wh1ch also covers carpus and chela of both chelipeds. Cutting edges f1ne, corneous, augmented by well-spaced calcareous teeth on pollex.

Walking legs exh1b1t asymetry as in Pagurus, those on right side longer. Both pairs armed dorsally only with a distal spine on carpus. Dactyl presents several corneous spinules on ventral margin. Horny claws bent downward. Dorsal and ventral surfaces of both palrs sparsely setose.

Fourth palr of perelopods Peebly chelate, dactyl equal. Ing propodus, almost four times as long as pollex portion. Rasp on ventral angle of propodus f1ve scales w1de, dactyl with fine row of scales. Propodus of fifth pair with rasp on distal half, including minute dactyl.

Pleopods as in Pagurus. Female from Cape San Blas carried 42 eggs, each approximately $0.5 \mathrm{~mm}$. In diameter. Left uropod much larger than right. Telson less asymme. trical; each terminal lobe with four sharp spinules, the outer recurved.

COZOR: Notes by Paul Bartsch on male from Blscayne Key, "Rose plnk with carmine long1tudinal stripes between jo1nts, eyes chestnut."

MEASUREMENTS (mm.): 0v1g. female from Panama C1ty. Shield, length 3.0 , w1dth 2.6, carapace 4.8; eyes 2.5 , 
right chela, length 3.0 , width 1.6 , dactyl 1.8 , left chela, length 2.7, w1dth 1.2, dacty1 1.5 .

REMARKS: When Bouvier deseribed this species Prom a female specimen in 1918 he realized that it might belong to another genus. However, he apparently did not count the gills and thus falled to realize that it could not be placed in existing genera. The f1rst three palrs of gills have been lost and the fourth is minute. The narrow eyestalks and spinous eye scales cause a superificial resemblance to Clibanarivs. No other intertidal pagurid in the area studied was found at as great depths. The range is shown to be extensive but the species is seldom abundant.

Genus Ostraconotus A. M1Ine Edwards

Ostraconotus snatulines A, Milne Edwards

Ostraconotus spatulipes A. Milne Edwards, 1880, p. 45. --Gordan, 1956, p. 321.

MATERIAL EXANTNED, Numerous specimens in type lot at MCZ. The location given for this lot as $26^{\circ} 31^{\prime} \mathrm{N} ., 85^{\circ} 53^{\prime}$ W., is almost certainly an error since the depth at that point would be at least 1700 Ims. The depth was given as 119 fms. and this is possibly correct.

RANGE: Gulf of Nexico? to Barbados; 119 ? to $140 \mathrm{fms}$. DIAGNOSIS: (After M1Ine Edwards and Bouvier, 1893). Body flattened, carapace calcified throughout; abdomen rud1- 


\section{0.}

mentary and symmetrical. Walking legs flattened, held out from sldes of body and probably adapted for walking on wud.

\section{Genus Pagurus Fabric1us}

Shleld seldom wuch longer than broad. Rostrum obtuse, never exceeding lateral teeth. Eyes always shorter than shield, dilated at corneas except in a few small forms from 1.1ttoral waters. Eye scales widely spaced, Plattened or with ralsed margins, latter type usually much narrower; a subapical denticle or spine at tip. Antennular peduncles equaling or exceeding eyes. Peduncles of antennae frequent. ly exceeding eyes; usually armed only on second segment, occasionally with a lateral recurved spinule at base. Acicle lacking teeth along sides. Flagellum nude or nearly so, except in annulines, usually equaling perelopods but shorter In some littoral species and exceeding in those from deep water.

Chelipeds more varlable than other parts of body. Right always larger, sometimes operculiform; not forming an opereulum when armed with sharp dentleles or spines. Cutting edges of major chela with strong calcareous teeth proximally, fine corneous end calcareous teeth distally. Minor cheliped slender but varying considerably between species in size, armament and proportionate length of dactyl. Cutting edges stralght although fingers often curve 
downward; teeth Plne, corneous except for a few calcareous teeth interspaced on pollex.

Walking legs slender, dactyls always the longest segments, claws sharp. Fourth pair of perelopods only slightly subchelate, propodal rasp composed of a single row of scales or about $1 \frac{1}{2}$ rows in most species from deep water, three or more rows in species from littoral or northern waters. Fifth pair chelate, fingers very short.

All specles exam1ned have four unpaired pleopods in the female, three in the male. Telson with a deep median cleft In nearly all specles; terminal lobes usually armed with spinules on margins.

\section{Genus Pagurus}

Key to Species

1. Propodal rasp of fourth perelopods composed of one or two rows of scales..................................

Propodal rasp of fourth perelopods composed of more

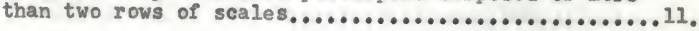

2. Major chela armed with varying numbers of spines on

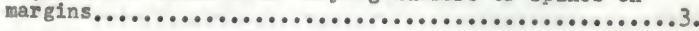
Major chela lacking sharp spines on margins..........6.

3. Carpus of major cheliped with sharp spines or denticles dorsally.....................................4.

Carpus of major cheliped armed only on margins.......5.

4. Dorsal surface of carpus and chela of major chellped with plentiful setae.................. rubrolineatus. 
Setae lacking on dorsal surfaces of these segments.......

5. Major chela armed dorsally with numerous short spines. a large species............................schmitt1.

Mafor chela with splnes only on Inner marg1n, a small species..............................ténuldactrius.

6. Major chela broad...............................? Major chela narrow................................

7. Minor chela with two thin ridges, a dorsal and a lateral ......................................evuracabensis.

Minor chela comparatively simple....................8.

8. Width of major chela subequal to length, minor chela with rounded margins, a reef species.......... onerculatus.

Major chela longer than wide, minor chela with definite margins, a deep water species................... occlusus.

9. Major chela three times as long as wide....... Iongimanus. Major chela less than $2 \frac{1}{2}$ times as long.................

10. Major chela rounded above and on edges; small species.... ...................................... rotundimanus.

Najor chela flattened above, with low, ridges; a large species...................................... bullis1.

11. Major chela armed with sharp spines or denticles......11. Najor chela tuberculate or granular...................16.

12. Eyes dilated considerably at cornea............ defensus. Eyes dilated only slightly at cornea................13.

13. Antennal Plagella short, with two ventrolateral rows of long setre................................ annul1ipes. Flagella long, equaling pereiopods, minutely setose...14.

14. Walking legs broadly banded, major chela lacking a complete row of Pine spinules on outer margin, or strong spines on inner margin................... bonairens1s. 
Walking legs striped, major chela with Inner and outer margins of spinules, or a row of strong spines near

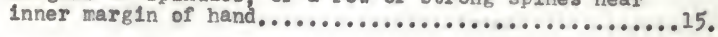

15. Najor chela armed with spinules on margins. brovidactiiü.

Major chela armed with a few strong spines on Inner dorsal margin of palm..................... stimpsonl.

16. Major chela long, granular on r1dges.......... longlearpus. Major chela heavy, broader than carpus.................

17. Najor chela covered with rounded denticles; a deep-water species.......................................11tus.

Major chela with mushroom_like tubercles, much as in

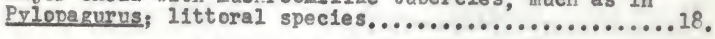

18. Tubercles of chelae widely separated, rounded, with dentate tips............................ pollicaris.

Tubercles of chelae contiguous at edges, completely covering dorsal surfaces. A dimple usuáliy present in each chela........................... Impressus.

\section{Pagurus annulipes (stimpson)}

Eupagurus annulipes Stimpson, 1859, p. 243.

Pagurus annulipes. PBehre, 1950, p. 22. -.Gordan, 1956, p. 325.

MATERIAL EXANINED: Thirty-nine specimens from three states.

Nassachusetts: Vineyard Sound; 1881; U. S. Fish Com. mission; 26 males, 7 females.

Georgia: Sapelo Id., Doboy Channel; July 17, 1958 ; J. M. Teal; 3 females (1 ov1g.).

Texas: Port Isabel Ship Channel; Mar. 15, 1947; J. W. 


\section{4.}

Hedgpeth; 1 male, 2 females, 211 very small.

RANGE: Massachusetts to Sapelo Id., Georgla; to elght

fms. Known in Gulf of Mexico only from coast of Texas.

DIAGMOSIS: Small form. Antennal flagellum short, not exceeding minor chela, with two rows of long, fine setae ventrally. Major chela usually much larger in males.

DESCRIPTION, Specimens from Massachusetts. Snleld broad, glabrous, especially on gastric reglon. Eyes short, not swollen distally. Antennular peduncle exceeding eyes by slightly more than antennal peduncle does. Aclele reaching cornea. Flagellum short, tapering, reaching only to midale of carpus of major cheliped in males from Massa. chusetts; reaching dactyl of chela in females.

Major cheliped heavy, elongated, In males from Massa. chusetts. Armament feeble; Inner margin of carpus and chela Irregularly dent1culate, also outer margin of pollex. Face of chela smooth except for two faint rows of minute denticles and line setae. Fingers gaping to hooked tips, with minute calcareous teeth except for one a little larger near base of dactyl.

Minor cheliped much shorter, often not reaching major chela in males. Carpus armed dorsally with two marginal rows of spinules. Chela similarly armed, with an inner and a mid-dorsal row of spinules. Fingers gaping proximally. Carpus of flrst pair of walking legs armed in males w1th one to elght spinules dorsally on right side, one on 
left; females with only a distodorsal spinule. Both walking legs with sparse fine setae; đactyl slender, lacking corneous spinules ventrally. Fourth perelopods with about four rows of scales in rasp. Telson triangularly lobed, armed with minute, straight spinules.

COLOR: Color from life, Woods Hole, 1905, by M. J. Rathbun. Body bright red with light mottlings. Pereiopods irregularly marked with transverse bands of brownish red and white. Distal half of chelae white, proximal half red.

MEASUREMENTS (mm.): Specimens from Massachusetts. Shleld, length 2.2, width 2.4; carapace 4.2; eyes 1.6; chelipeds; (a-male, b-female) major cheliped, a.10.5, b-5.7, chela, length, a-4.2, b-2.1, width, a-2.0, b-1.2, dacty1, a. 2.0 , b.1.2, minor cheliped, length, a.6.5, b-4.8, chela, length 2.4, carpus 1.8, propodus 2.9, dacty1 3.5 .

REMARKS: Most of the females from Massachusetts show signs of having borne eggs when collected or Just before, even though they are considerably smaller than the males. Dimorphism is most evident in the major cheliped. The carpus has several irregular rows of sharp denticles on the dorsal surface. The chela has four dorsal rows plus a complete outer margin of denticles. The extent of this dimorphism in Georgla and Texas has not been observed. The female from Sapelo Is. carries about 150 eggs. 


\section{6.}

Pagurus bonairensis Schmitt

Pagurus benalrensis Schmitt, 1936, p. 376. _Gordan, 1956, p. 327.

Pagurus annulides Schmitt, 1935, p. 206. -.Behre, 1950, p.22. --Wass, 1955, p. 152.

MATERIAL EXAVINED; Two hundred and seventeen specimens Irom nine localities.

Missission: Horn Id.; Aug. 9, 1950; J. Beale; 2 males. Elorida: Crooked Is. Sound, Apalachicola; Fob. 10, 1936; A. L. Pearse; 11 males, 5 females, 1dent, by W. L. Schm1tt. Sea Horse Key; Apr. 19, 1958; 6 males. Lemon Bay, Jan., 1938; 0. Hartman; 106 males, 74 females (46 ov1g., 15 with eggs in ovaries). Tortugas, Loggerhead Key, eel grass, July 3, 1932; W. L. Schmitt, 3 males, I ovig. Pemale; June 22, 1925; $15-20$ feet; 1 ovig. female; June 11, 1925; 20 feet; 1 male, 1 ovig. female.

Cuba: Siguanea Bay; 12.26 feet; Apr. 12, 1931; P. Bartsch, 1 male, 1 juv.

PuertoRieo: Mayaguez; Jan. 19, 1898, "Fish Hawk", 1 male. Bogueron, East Point Beach, among eel grass; Willis G. Hewatt, 4 males.

Braz11: Isla Govenador, outs1de mouth of river; Sept. 1, 1925; W. L. Schm1tt, 2 males.

RANGE: Mississipp1, along northern and eastern edges of Gulf of Merico, through West Indies to Brazil; to 20 feet. 
DIAGNOSIS: Antennal Plagellum long, equaling pere1. opods; almost nude.

DESCRIPTION: Shleld smooth on gastrie region, convex and feebly setose laterally. Anterior projections obtuse, approximately equal. Eyes shorter than shleld, slightly swollen at each end. Eye seales moderately separated. Antennular peduncle exceeding eyes; that of antennae equal. ing. Flagellum slender, minutely setose at articulations. Chellpeds feebly armed, w1th denticles obscured by setae. Carpus and chela of major cheliped with two rows of denticles above, separated by a slightly depressed area. Major chela with a row of denticles on each margin and two median rows on palm. Fingers short, closing almost completely.

Minor cheliped with a few denticles in two dorsal rows. Chela triangular in cross section, finely dentieulate dorsal. 19. Fingers gaping in proximal half.

Walking legs with a distodorsal denticle on earpus, corneous spinules on ventral engles of dactyls. Shape and armament of telson similar to that of annulines.

MEASURENENTS ( $\mathrm{mm}$. ): Since the specimens examined varied greatly, measurements of four specimens are given in the following table. No. 1, a male from Crooked Is. Sound; no. 2, a male from Sea Horse Key; no. 3, a male from Lemon Bay; no. 4, a female from Lemon Bay. The actual measure. ments are given for no. 1 and the ratios of each measure. 
ment divided by the shield length for this specimen and the other three.

Shield, length 3.0 ratio 2 (rat 10$)$ 3(ratio) 4 (ratio)

$\begin{array}{llllll}\text { Shleld, w1dth } & 3.0 & 1.0 & 0.9 & 0.9 & 0.9 \\ \text { Carapace } & 4.7 & 1.6 & 1.7 & 1.6 & 1.6 \\ \text { Eyes } & 2.6 & 1.9 & 0.9 & 1.0 & 0.8 \\ \text { Major cheliped } & 9.2 & 3.7 & 4.1 & 5.3 & 3.5 \\ \text { Chela, length } & 4.2 & 1.4 & 1.4 & 2.3 & 1.2 \\ \text { Chela, width } & 1.6 & 0.5 & 0.8 & 1.0 & 0.6 \\ \text { Chela, dactyl } & 1.8 & 0.6 & 0.8 & 1.0 & 0.6 \\ \text { Minor cheliped } & 7.5 & 2.5 & 2.9 & 3.4 & 2.8 \\ \text { Chela, length } & 3.4 & 1.1 & 1.2 & 1.3 & 1.0 \\ \text { Chela, w1dth } & 1.4 & 0.5 & 0.5 & 0.4 & 0.4 \\ \text { Chela, dacty1 } & 1.8 & 0.6 & 0.6 & 0.7 & 0.5 \\ \text { Third right } & & & & & \\ \text { perelopod } & & & & \\ \text { Bas1s_1sch1um } & 1.9 & 0.6 & 0.6 & 0.7 & \\ \text { Merus } & 3.0 & 1.0 & 1.0 & 1.1 & \\ \text { Carpus } & 2.5 & 0.8 & 0.8 & 0.9 & \\ \text { Propodus } & 3.5 & 1.2 & 1.1 & 1.3 & \\ \text { Dactyl } & 4.3 & 1.4 & 1.4 & 1.6 & \end{array}$

RIMARKS: . bonalrensis exhlbits greater variation than any other form encountered in this study. The many specimens Prom Lemon Bay on the lower west coast of Florida show the most divergence, the males having an unusually large and elongate major cheliped which generally exceeds the walking legs. Also, the latter have the chelae with spinulose rather than denticulate margins while the dorsal surfaces of the carpus and chela bear numerous sharp denticles and a rather thick covering of setae.

The type specimen could not be located at the USNM. The specimens from Crooked Is. Sound were determined by Schmitt and flt his description of the specles quite well. Specimens from Lemon Bay differ mainly in the form of the 
chelipeds and exhibit as great an amount of sexual di. morphism as specimens of $P$. annulipes from Massachusetts. Females from Lemon Bay were estimated to carry up to 750 eggs.

\section{Pagurus brevidactrlus Stimpson}

Eupagurus brevidactylus St1mpson, 1859, p. 91.

Pagurus marsh1 Benedict, 1901, p. 140, 2 11gs. --Gordan, 1956, p. 331.

Pagurus brevidactylus Gordan, 1956, p. 327.

MATERIAL EXAMINED; Th1rteen specimens from seven 10. calities.

Tlor1da (west coast): Sea Horse Key; Nov, 2, 1957, 2

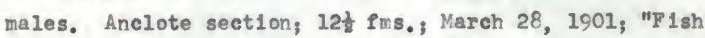
Hawk" sta. 7106; 1 ovig. Pemale. Cape Florida; Jan., 2925; J. W. Miller; 1 wale, I Semale; west of Loggerhead Key; 5.8 Pt.; Aug. 3, 1924; W. I. Schm1tt, 1 female. Cube: $21^{\circ} 57^{\prime} 11 ., 82^{\circ} 33^{\prime}$ W.; Apr. 15, 1931; P. Bartsch, I ovig. female with an attached Stegophrixus 1sopod. Cardenas Bay, 2 fms.; Jan. 24, 1957; W. L. Schm1tt; 1 female with gravid ovarles.

Puerto Rico: Jan. 30, 1899, "Fish Hawk"; 4 males, 1 ovug. Pemale (types of $\mathrm{P}$. $\operatorname{mar} \operatorname{sh} 1$ ).

RANGE: Sea Horse Key, Fla., to Puerto Rico; to $12 \frac{1}{2} \mathrm{fms}$. DIAGNOSIS: Walking legs long1tudinally striped. Eye- 
stalks with a low papilla midway on Inner surface giving rise to three or four fine setae. Major chela with a row of sharp spinules on outer margin.

DESCRIPTION: Shield glabrous, feebly setose laterally. Rostrum blunt, little in advance of obsolescent lateral teeth. Eyes slender, a notch at base of cornea; latter somewhat bulbous. Stalks present several transverse tufts of setae, largest of which stems from a ralsed spot midway on Inner surface. Scales broad, well separated. Antennular peduncle slightly exceeding eyes, antennae subequal.

Major cheliped armed on merus with a strong spine at Inner ventral angle, another at distodorsal angle, three spinules on outer distoventral angle. Carpus armed with a double row of spines on inner dorsal angle, an irregular double row of dorsolateral spinules. Chela with two spines next to inner hinge, sharp denticles more distally, a strong outer margin of vertical spinules, and two dorsal rows of denticles which meet distally. Dactyl with an outer and a dorsal row of fine denticles.

Merus of minor cheliped with two spinules on inner ventral angle, five on outer. Carpus armed above with two irregular rows of spines. Chela triangular above, with spinules on apical ridge; a short row of strong denticles on Inner dorsal surface of palm; two rows of fine denticles converging distally on outer side. Fingers gaping proximally. Walking legs with a few fine setae, a ventral row of ten 
Pine corneous spinules on dactyls; claws curved down slight. 1y.

COLOR: (from Stimpson) "Color pale reddish, feet with Interrupted long1tudinal stripes of darker red."

MEASUREIENTS (mm.): Male from Sea Horse Key. Shield, length 2.7, w1dth 2.5; carapace 4.5 ; eyes 2.5 ; major chela, length 4.1, width 2.1, dactyl 1.8 , minor chela, length 2.8 , width 1.2, dactyl 1.9; third right perelopod, basis-1schium 1.2, merus 2.2, carpus 1.9, propodus 2.3, dacty1 2.6.

REMARKS: This species is closely related to P. annulipes, P. bonalrensis, and $P$. stimpsonl, being most near to the latter species. It differs from stimosoni in having a complete margin of stronger spinules on the outer angle of the major chela, longer eyestalks, shorter antennular peduncles, and shorter dactyls in the walking legs. It is possible that intermediates may be found between these two species, in which case stimosoni could be no more than a subspecies found at greater depths. The specimens examined fit Stimpson's description, except that the dactyls of the walking legs are a little longer, Instead of shorter, than the propodi. Since he gave no actual measurements it is impossible to determine the extent of this differencs. The type is not extant.

Pagurus bullisi n. sp.

MATERIAL EXAMINED: Fourteen spec1mens from coasts of 
four Gulf states.

Holotyne male; off northwest Florida; $29^{\circ} 16^{\prime} \mathrm{N} ., 86^{\circ}$ $10^{\prime}$ W.; 125 fms.; Sept. 7, 1955; "Oregon" sta. 1383. Allotype female; off Mississippl; $28^{\circ} 01^{\prime} \mathrm{N} ., 90^{\circ} 53^{\prime} \mathrm{W} . ; 125$ Pms.; Sept. 21, 1955; "Oregon" sta. 1413. All other spec1mens are designated paratypes.

Osf Texas: $27^{\circ} 17^{\prime} \mathrm{N} ., 96^{\circ} 25^{\prime} \mathrm{W} . ; 75 \mathrm{fms.3}$ Jan. 30 , 1939, "Pellcan" sta. 111-4, 1 male.

Off Loulstana: $28^{\circ} 14^{\prime} \mathrm{N}$, , $91^{\circ} 41^{\prime} \mathrm{W}_{. ;} 39$ fms.; July 12, 1938; "Pellcan" sta. 84-3; 1 male, $28^{\circ} 09^{\prime} \mathrm{N} ., 91^{\circ} 32^{\prime}$ W.; 49 fms.; July 12, 1938, "Pellcan" sta. 85-2; 3 males. $28^{\circ} 09^{\prime} \mathrm{N}_{\text {., }} 91^{\circ} 27^{\prime} \mathrm{W}$.; 50 Pms.; July 12, 1938; "Pellcan" sta. $85-3 ; 1$ ovig. Pemale. $28^{\circ} 11^{\prime} \mathrm{N} ., 91^{\circ} 24^{\prime} \mathrm{W}, 47 \mathrm{fms}$, ; July 12, 1938; "Pel1can" sta. 85-4; 2 males.

off M1ss1ssipo1: $29^{\circ} 04^{\prime}$ N., $88^{\circ} 4^{\prime} \mathrm{W}$.; 60 Ims.; May 24, 1938; "Pel1can" sta. 74-3; 1 male.

off Northwest Florida: $\quad 28^{\circ} 22^{\prime} \mathrm{N} ., 89^{\circ} 59^{\prime} \mathrm{W}_{0} ; 65 \mathrm{fms.3}$ Sept. 22, 1955; "Oregon" sta. 1419; 1 male. $29^{\circ} 47^{\prime} \mathrm{N} ., 86^{\circ}$ 51.5' W. 98 Ims.; "Pelican" sta. 144-2; 1 male. $29^{\circ} 34^{\prime} \mathrm{N}$., $86^{\circ} 33^{\prime}$ W.; 100 fms.; Sept. 10, 1955; "Oregon" sta. 1396, 1 male in Phallum shell.

RANGE; Northern Gulf of Mexico, Texas to Florida; 39 to 125 fms.

DIAGNOSIS: Largest species of Pagurus in Gulf of Mexico, body up to four Inches long. Chelipeds long, narrow, nude except along cutting edges of PIngers; major member unarmed 
on dorsal surface, both feebly armed on margins. Sharp margins and ridges on fingers extend to tips.

DESCRIPTION: Sh1eld smooth, little rounded; rostruin equaling lateral teeth; a minute spinule on each lateral tooth, none on angled peak of rostrum; margin raised between lateral teeth. Cardiac plate very narrow, blfurcat. Ing posteriorly.

Eyes little swollen at base of stalks, much more so at cornea. Eye scales broad, margins upturned; subapical spinule present. Antennular peduncle small, exceeding eyes by two-thirds of terminal segment. Sharp, curved, lateral spine at base of antennal peduncle. Second segment with spinule on Inner angle, several on inner edge of outer pro. jection before bifld t1p. Terminal segment exceeding eyes by one_half, acicle spine-tipped, exceeding eyes a third. Flagellum nude; exceeding legs.

Major cheliped denticulate on dorsal surfaces; armed with several spines on distoventral and distodorsal margins of merus; carpus with 10.12 spines on Inner margin. Hand armed with 15 sharp denticles on inner margin of palm, serrate outer margin of small denticles to tip of pollex, serrate outer margin and dorsal ridge on dactyl. Cutting edge typical of Pagurus, with proximal crushing teeth and distal cutting edges.

M1nor cheliped armed dorsally and laterally; meral armament much as in major cheliped; carpus with spines on 
Inner dorsal margin, outer distodorsal margin and dorsal ridge. Palm of chela produced dorsally, with a few spines on highest part; inner margin dentate, outer margin serrate to tip of long pollex. Margin and dorsal ridge of dactyl granulate, with evenly concave depression between. Fingers with thumb-like corneous tips and typical cutting edges; about 12 tufts of strong setae near each cutting edge form a lattice-work with IIngers closed.

Second perelopods armed with spines on dorsal angles of carpus and propodus; third perelopods armed only on distal half of dorsal angle of these segments. Dactyls twisted outward distally, with thick setae on dorsal and ventral margins pointed Inward and distally to form a walking surface on Inner face. Propodus of fourth perelopods with usual rasp of a single row of broad scales; dactyl with a single row of minute scales. Rasp of P1fth perelopods covers distal threeI1fths of propodus; one row of scales on dactyl. Unpalred pleopods of male with a prominent external ramus a third as long as internal ramus. Telson asymmetrical; distal lobes with comb-like teeth on outer edges, inner spinules forming a more serrate margin.

COLOR: Merus of first three perelopods marked by d1agonal lines of red near the inner distal margins, with less intense color on outer margins. Same color on distoventral half of eyestalks.

MEASUREMENTS (mm.): Shleld, length 17.5 , width 18.5; 
carapace 33.5 ; eyes 11.5; major chela, length 46, width 21 , dactyl 22.5; minor chela, length 37, width 12, dactyl 24.5; third leg, bas1s-1schiva 13, nerus 25.5, carpus 19, propodus 25.5, dacty1 41 .

\section{Pagurus coker1 Hay}

Pagurus coker1 Hay, 1917, p. 73. --Springer and Bull1s, 1956, p. 16. -Gordan, 1956, p. 328.

MATERIAL EXAMINED: Four specimens from four stations. North of Little Bahama Bank: $27^{\circ} 27^{\prime} \mathrm{N} ., 78^{\circ} 58^{\prime} \mathrm{W}$. ; 180 fms.; Feb. 2, 1957; "Combat" sta. 235; 1 juven1le. $27^{\circ}$

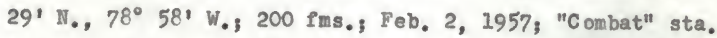
236; 1 juven1le, $27^{\circ} 28^{\prime} \mathrm{N} ., 78^{\circ} 4^{\prime} \mathrm{w}_{.} ; 215 \mathrm{fms}, 3$ Feb. 2, 1957; "Combat" sta. 237; 1 female.

Carlbbean Sea: West of Rosalind Bank; $16^{\circ} 07^{\prime} \mathrm{N} ., 81^{\circ}$ 05 ' W.; 130 Ims.; Aug. 24, 1957; "Oregon" sta. 1891; 1 Pemale. RANGE, Cape Lookout, N.C., Tortugas Ids., Fla. to Caribbean Sea; 130-263 fms.

DIAGNOSIS: Eyes dilated distally. Chellpeds not mark. edly unequal; carpl and chelae well armed with sharp spines dorsally. Dactyls long, compressed.

DESCRIPTION: Shleld roughly quadrate, rostrum rounded, equal to lateral teeth; latter tipped with minute spinules. Raised margins begin on elther side of rostrum, extend to lateral teeth. Posterolateral plates of shield long, extending on elther side from most lateral to rost posterior 
part of shield. Cardiac plate narrow, poorly calcifled. Eyes half as long as shleld; cornea considerably swollen. Eye scales broad, trlangular; concave above; subapical splne present. Antennular peduncle rather small, exceeding oyes by half of terminal segment. Antennal pe. duncle with minute spinule posterolateral to base; second segment with a spinule at inner angle, five on inner margin of outer profection; terminal segment exceeding eye by two. thirds; acicle exceeding by terminal spine. Flagellum equaling perelopods, nude except for a few stiff setae.

Major chellped with three distodorsal spines on merus. Carpus and propodus thickly set with sharp spines on dorsal surfaces and margins; largest spines in inner marginal row of carpus, outer row of propodus. Cutting edges of fingers with large teeth proximally; distal edge typical of genus, with eurved row of 18 corneous teeth on dactyl meeting several larger, calcareous teeth on pollex. Minor cheliped narrow, nearly as long as major member; armament similar; cutting edges typical, dactyl closing beneath pollex.

Second and third perelopods long, surpassing major chellped by nearly half of each dactyl. Nerus dentate on ventralmost surface. Carpus and propodus armed dorsally with spines and denticles, more strongly so on first leg. Dactyl long, straight proximally, somewhat curved near tip. Two rows of strong, corneous setae on distal fourth of ventral surface apparently aid long, stralght claws in walk. 
Ing on soft surfaces. Propodus of fourth perelopods a row of single scales; dactyl stout, squarish. Propodus of fifth pereiopods chelate; rasp on a little more than distal half, dactylar rasp a short row of scales. Telson asymmetrical, unusually armed; finely dentate on outer edges and Inner faces of both lobes; small spinules at tips.

COLOR: Apricot on distal margins of merus and on Inner dorsal margin of carpus of chelipeds. Merus of second perelopods with same color near distal margin and outer dorsal stripe.

MEASUREMENTS (mm.): Male from "Oregon" sta. 1891, Shield length 10.5, width 11.0 , carapace 18.5; eyes 6.2, major chela, length 20.5, width 10.5, dactyl 11.0, minor chela, length 18.8 , width 7.0 , dactyl 11.0 , third leg, basis-1sch1um 8.0 , merus 12.7 , carpus 9.5, propodus 11.4, dactyl 24.0 .

\section{Pagurus curacaoensis (Bened1ct)}

Eupagurus curacaoensis Benedict, 1892, p. 22.

Eupagurus curacoens1s (m1speling) Alcock, 1905, p. 181.

Pagurus curacoensis (m1spelling) Gordan, 1956, p. 329. Pagurus curacaoensis Springer and Bull1s, 1956, p. 16. MATERIAL EXANINED: Fifteen specimens from P1ve widely separated localities.

Type male, USNM 7835; Curacao; 208 Ims,; 1884; "Albatross" 


\section{8.}

sta. 2125.

Gulf of Nexico: $29^{\circ} 00^{\prime} \mathrm{N} ., 88^{\circ} 35^{\prime}$ W.; $220 \mathrm{fms.;} \mathrm{Apr.}$ 22, 1951, "Oregon" sta. 307, 1 male; East of M1ss1ssipp1 River delta, $29^{\circ} 10^{\prime}$ N., $88^{\circ} 03^{\prime} W_{.3} 260$ fms.; Mar. 13, 1955; "Oregon" sta. 1282, I male. $29^{\circ} 13^{\prime}$ N., $87^{\circ} 54^{\prime}$ W.; 250 Pms.; June 22, 1956; "Oregon" sta. 1566, 2 ovig. females. $24^{\circ} 29^{\prime}$ N., 83 27' W.; 212 Pms.; June 15, 1956; "Oregon" sta. 1537; 1 male; $24^{\circ} 42^{\prime} \mathrm{N} ., 83^{\circ} 08^{\prime} W_{0} ; 30$ fms.; June 18, 1957; "Oregon" sta. 1553; 1 male; July 31, 1930, 220-237 fms.; W. L. Schmitt; 2 ovig. Pemales. July 8, 1931; $200-253$ fms.; W. I. Schmitt; 1 male, I ov1g. Pemale. July 19, 1932, 295. 315 Pms.; W. L. Schm1tt; 1 male. Aug. 3, 1932, 249-358 Pms.; W. L. Schmitt; 1 juvenile. $19^{\circ} 37^{\prime} \mathrm{N} ., 92^{\circ} 40^{\prime} \mathrm{W} .: 200 \mathrm{Pms.}$; May 15, 1954; "Oregon" sta. 1054; 1 male.

Oef mouth of Amazon River: $01^{\circ} 49^{\prime} \mathrm{N} ., 46^{\circ} 48 \mathrm{\prime}$ W.; 225 fms.3 Nov. 17, 1957; "Oregon" sta. 2083; 1 female.

RANGE; Northern Gulf of Mexico to mouth of Amazon River; 200 to 295 Pms. (30 Pms. record doubtful).

DIAGNOSIS: Major cheliped broad; dorsal surface of carpus denticulate, of chela smooth, with upturned margin. Minor chela small, with prominent, thin plate forming a long1tudinal, dorsal ridge.

DESCRIPTION: Shield glabrous, with minute setae at punctae In longitudinal grooves. Rostrum triangular, exceedIng rounded, lateral teeth. Cardlac plate narrow, calclfled throughout and on adfacent areas of carapace. 
Eyes short, little swollen distally. Bye scales proml. nent, long triangular; convex on upper surface and with a small, subapical spine. Strong antennular peduncle exceed. Ing eyes by terminal segment. Antennal peduncle exceeding by half of terminal segrent; second segment with a small spine at inner angle and at tip of long outer projection. Ac1cle without a spine, exceeding eye by a fourth. Fla_ gellum nude, extremely slender, equal to legs.

Major chellped opereullform; dorsal and lateral surfaces of merus with low crests; ventral surface denticu. late behind crenulate anterior margin. Carpus armed with granules and sharp dent1cles on dorsal surfaces; lateral margins raised, Inner denticulate, outer of eight blunt spines; distal margin of uneven dent1cles. Dorsal surface of chela very Pinely granulate; nude except for a few small tufts of setae along gape. Margins heavy, ra1sed, bluntly crenulate. Gape closes throughout; ralsed, Peebly-serrate edge in center of pollex culminates in a broad tooth about a third of distance from tip and continues as a sharp edge to four small teeth near tip. Edge of dactyl presents a re. cession to recelve large tooth on pollex, then a rounded tooth next to corneous edge leading to small corneous tip.

Carpus of minor chela armed with two dorsal rows of spines and denticles; outermost row meets apex of distal recession in margin; latter presents a strong spine on each side. Propodus with a raised, somewhat wavy crest on dorsal 
surface to tip of pollex and a similar crest at lateral margin, with a broad depression intervening. A few low denticles line inner margin of palm and adfacent edge of dactyl, with four others on proximal end of low dorsal ridge of dactyl. Cutting edge of typical, fine corneous and calcareous teeth on pollex meeting even corneous edge of dactyl.

Walking legs spinulose on dorsal angle of carpus, denticulate on that of propodus. Dactyl with a few short setae on Inner dorsoventral edge; strongest near short, amber tips. Rasp on propodus of fourth perelopods composed of two rows of scales; short dactyl with a fine rasp in Iine with tip of claw. Chelate propodus of fifth perelopods with a rasp on distal half.

External ramus of unpaired pleopods stronger than usual, up to a third of length of Internal ramus. Uropods and telson strongly asymetric; triangular distal lobes well armed on inner borders; spinule at each tip curved outward. COLOR: A striking pattern of orange color in varying intensity appears on bases of eyestalks, eye scales, second segment of antennal peduncle, acicle, anterior margins of merus and carpus of chelipeds and on walking legs at proxImal and distal ends of all segments beyond coxa except carpus, which has only a distal band. Dactyl yellow prox1mally on ventral and dorsal margins, distal third orange. MEASURBMENTS (mm.): Shield, length, 8.0, w1dth 7.5; 
carapace 13.0 , eyes 4.0 , major chela chela, length 17.7 , width 12.0 , dacty 8.0 , minor chela, length 9.8 , width 5.2 , dactyl 6.0 , third leg, basis-1schium 6.0 , merus 8.2 , carpus 7.1 , propodus 7.6 , dactyl 12.8 .

\section{Pagurus defensus (Benedict)}

Euvagurus defensus Bened1ct, 1892, p. 7.

Eupagurus dissimilis A. Milne Bdwards and Bouvier, 1893, p. 146, pl. 10, Iigs. 19-25;

Pagurus d1ssimi11s Gordan, 1956, p. 329.

Pagurus defensus Gordan, 1956, p. 329.

MATERIAL EXAMINED; Fourteen specimens from six locali. ties.

Alabama: $29^{\circ} 45^{\prime} \mathrm{N} ., 87^{\circ} 45^{\prime} \mathrm{W} .321$ fms.; Mar. I, 1939; "Pelican" sta. 136-2; 1 male.

North Carolina: off Cape Lookout; $22 \mathrm{fms.3}$ 1885; "Albatross" sta. 2609, 1 male.

Wlorida (east coast): Orf Daytona, $29^{\circ} 20^{\prime} \mathrm{N} ., 80^{\circ} 15^{\prime}$ W.; 35 fms.; June 2, 1957; "Combat" sta. 345, I male, cara_ pace length $17 \mathrm{~mm}$. $18 \mathrm{ml}$. southwest of DestIn, Fla.; 18_20 fms.; Oct., 1941, T. J. MeGinty, 2 males.

Florida: $29^{\circ} 28^{\prime} \mathrm{N} ., 85^{\circ} 31^{\prime} \mathrm{W}_{\circ} ; 12 \mathrm{fms}$, ; Feb. 1, 1956,

"A. A. Jakkula", 3 males, 3 females ( 1 ovig.).

Tortugas: 40.45 fms.; Paul Rartsch; 1 male. 16 Ims.;

J. B. Henderson; 1 male. 
Yucatan Bank: Alacran Reef, 20 fms., "Blake" sta. 38, 1 male (type of Eupagurus dissimilis A. Milne Edwards and Bouvier).

RANGE: North Carolina to Florida, Gulf of Mexico, 12 to 40 fms.

DIAGNOSIS: Byes subequal to shleld; chellpeds armed mainly on margins, setose dorsally. Antennal plagellum nude, exceeding pereiopods.

DESCRIPTION: Shield small, quite elattened; rostrum obsolescent, considerably exceeded by triangular lateral teeth. Eyes large, dilated distally. Eye scales broad, Plat, rounded anteriorly, each with subapical spinule. Antennular peduncle exceeding eye by two-thirds of terminal segment. Second segment of antennal peduncle dentate on inner angle, outer projection terminating in a spine. Terminal segment slightly exceeding eye, rlagellum nude, cons1derably exceeding perelopods.

Faces of chelae covered with mushroom-like tubercles on distal half, each tubercle tipped with a short spine or denticle. Meri of chellpeds spined distally on dorsal and ventral margins. Carpus of major chela with a median dorsal and an inner dorsal row of elght spines each, with several spines between these rows and numerous spinules on outer dorsal surface. Carpus of ainor chela narrow, w1th two rows of sharp spines dorsally. Both chelae with two converging rows of spines on dorsal surface and marginal rows of sharper 
spines. Nushroom tubercles begin at termination of converging rows of spines. Fingers falrly typical, gape absent on both hands. Cutting edges of dactyl with more, and stronger, calcareous teeth than usual in genus. Tips calcareous on large hand, corneous on small. Carpi and chelae covered w1th IIne, dense setae dorsally.

Carpus of second perelopods with elght to ten spines on dorsal angle, 11 to 13 on that of propodus. Carpus and propodus similarly armed on third perelopods, but with spinules and denticles. Dactyl rounded on outer surface, more Plattened on Inner; a fine long1tudinal groove on each. Dorsal and ventral rows of setae on dactyl directed Inward. Fourth perelopods with a ventral rasp three seales wide on propodus. Dactylar rasp of 11 scales increasing in size distally; tip strong, curved. Fifth perelopods with a rasp on outer distal half. Telson well armed on trlangular terminal lobes, especlally on outer margins.

COLOR: Bye stalks shading from light purple at constrict. ed part to deep purple near black cornea. Surfaces of chel1. peds apricot, with spines salmon to coral p1nk. Two convergent rows of spines on each cheliped white on smaller spec1mens.

MEASUREMENTS (mm.): Shleld, length 6.5, width 7.3 ; carapace 14.0; eyes 5.5; major chela, length 14.0 , width 7.8 , dactyl 6.6 ; minor chela, length 10.6 , width 4.5 , dactyl 5.8, third pere1opod, bas1s-1schium 4.7, merus 8.5 , carpus 
164.

6.8 , propodus 8.5 , dactyl 15.8 .

\section{Pagurus 1mpressus (Benedict)}

Eupagurus 1moressus Benedict, 1892, p. 5.

Pagurus 1mpressus Wass, 1955, p. 152. -_Gordan, 1956, p. 330 .

MATERIAL EXAMINED: Fifty-eight specimens from four states.

North Carolina: $34^{\circ} 33^{\prime} \mathrm{N} ., 76^{\circ} 41$ ' W.; 9 Ims.; Feb. 12, 1940; "Pellican" sta. 185.5, 1 in shell of Polmices. South Caroling: $33^{\circ} 33^{\prime} \mathrm{N} ., 77^{\circ} 42^{\prime}$ W.; 9 Pms.; Fob. 15, 1940, "Pellcan" sta. 184-7, 1 in shell (a tunicate had made a dwelling of sand grains on the 11p of the shell, with a tiny flat stone forming a roof over the walls of agglut1. nated sand grains). $32^{\circ} 49^{\prime} \mathrm{N}_{0}, 79^{\circ} 28^{\prime}$ W.; 6 Ims.; Feb. 12, 1940, "Pelican" sta, 182_15; I ovig. female, I male in Busycon shell.

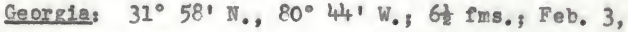
1940; "Pellcan" sta. 181.1; 1 in Strombus shell. $31^{\circ} 07$ ' N., $81^{\circ} 05^{\prime} W_{.3} 7$ fms.; Jan. 31 , 1940, "Pelican" sta. 178-3; 2 In shells. $31^{\circ} 01^{\prime} N_{0}, 81^{\circ} 10^{\prime} W_{0} ; 7$ fms.; Jan. 26, 1940, "Pelican" sta. 177-12; 1 ovig. ferrale, carapace length $8 \mathrm{~mm}$.

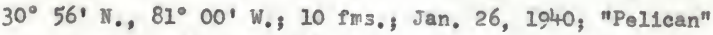
stā. 177-10, 2 males, larger with carapace length $27 \mathrm{~mm}$. Florida (east coast): $28^{\circ} 45^{\prime} \mathrm{N} ., 80^{\circ} 27^{\prime} \mathrm{W}_{0} ; 10$ fms.; 
Jan. 19, 1940; "Pel1can" sta. 171-2, chelipeds and walkIng legs.

Florida (west coast): Cape San Blas, $29^{\circ} 28^{1} \mathrm{~N} ., 85^{\circ}$ 31' W.; 12 fms.; Feb. 1, 1956; "A. A. Jakkula", 1 ov1g. female, carapace length $7.5 \mathrm{~mm}$. Apalachee Bay, $8 \mathrm{~m} 1$. south of Ochlockonee River; Mar. 10, 1957; George D. Grice; 2 males. $213 / 4 \mathrm{m1}$. northeast of Cedar Key L1ght, $53 / 4 \mathrm{sms} . ;$ Jan. 11, 1913; "Fish Hawk" sta. 7807; 1 juven1le. Tampa Bay; 5 Ims.; Apr. 1, 1901; "F1sh Hawk" sta. 7117, J. E. Bened1ct; 15 males, 26 females (11 ov1g.). off Cape Sable, $25^{\circ} 10^{\prime} \mathrm{N}_{0}, 82^{\circ} 22^{\prime} W_{0} ; 3$ 3/4 Ims.; Dec. 17, 1902, "Fish Hawik" sta. 7352, 1 male.

RANGE; North Carolina to Cape Canayeral, Fla., on Atlantic coast; Cape Sable, Fla. to Texas in Gulf of Mexico; intertidal to 12 fms.

DIAGNOSIS: Chellpeds similar, right 11ttle larger than lert; Pace covered with plates as in some prlopagurus. Chelae with a deep dimple between base of dactyl and outer margin.

DESCRIPTION: Shield smooth medially, flattened. Eyes short; cornea much broader than base of stalk. Eye scales broad, rounded; subapical spine minute. Eyes exceeded by antennular peduncle, equaled by that of antenna. Acleles barely reaching cornea. Flagellum nude, equaling perelopods.

Chelae with prominent ridges and depressions. Surface plates rounded, much smaller in depressions than on ridges. 
Margins armed with blunt teeth which point upward and outward. Prominent depressions include a central dimple and a proximal groove separated from Inner margin by a ridge. Walking legs flattened, particularly in dactyl. Latter with a fine longitudinal groove on Inner side. Propodal rasp of fourth perelopods with about six rows of fine scales. Telson very asymmetric, left lobe armed with straight, cal. careous teeth; median Indentation scarcely marked.

MEASUREMENS (mm.): Male Irom Apalacheo Bay. Shield, length 11.5, width 11.3; carapace 2.8; eyes 9.5 ; r1ght chela, length 25.0 , width 16.0 , dacty 1 16.0, left chela, length 19.0, w1dth 13.0, dactyl 11.0; third right perelopod, basis. 1 schium 8.5 , merus 12.5 , carpus 11.2 , propodus 10.7 , dacty 1 19.0 .

\section{Pagurus Longlcarous Say}

Pagurus longlearpus Say, 1817, p. 163. --Wass, 1955, p. 152. --Gordan, 1956, p. 331.

Pasurus truncatulus Rafinesque, 1817, p. 47.

Eunagurus longlcarnus St1mpson, 1858, p. 237.

Eupagurus longlies Coues, 1871, p. 124.

Dardanus truncatulus Gordan, 1956, D. 316.

MATERIAL EXAMINED: N1ne specimens from two states.

Chesapeake Bay: Off Kiptopeke Ferry landing; $80.90 \mathrm{ft}$, Feb. 15, 1955; Virginia Fisheries laboratory; 2 males. 
Flor1da: Off Jacksonville; $30^{\circ} 25^{\prime} \mathrm{N} ., 81^{\circ} 18^{\prime} \mathrm{W} . ; 8$ Ims.; Jan. 25, 1940; "Pellcan" sta. 176.1; 1 in shell. West coast, Sea Horse Key, south side of beach at low tide, Sept. 29, 1957; Doyle Folks; 6 males.

RANGE; Nassachusetts to Florida; Texas to lower west coast of Florida; to 18 fms.

DIAGNOSIS: Chelipeds long and narrow, surfaces granular, low dorsal ridge on carpus and chela.

DESCRIPTION: Shleld broad, rather elat. Eyes short, stout, swollen distally; two rows of Einute setae above. Eye scales typical, strong. Antennular peduncle weak, equalIng that of antenna. Flagellum of latter nude, equaling perelopods.

Major cheliped considerably larger than minor; both unarmed. Nedian dorsal ridges of carpus and chela marked by low, spaced tubercles or granules. Outer margin of pollex on right chela serrate. Minor chela curved downward; slight proximal gap in cutting edges.

Walking legs slender; dactyl long, curved outward at tips to form walking surface; claw weak. Propodal rasp of fourth perelopods with three or four rows of minute seales. Telson subsymetrical, well armed with ealcareous spinules distally.

COLOR, Indian red longltudinal stripes on dorsal ridges of chelipeds, both sides of carpus of chelipeds, also 
on sides of carpus and propodus of walking legs. Oblique stripes of same color distally on both sldes of carpus of all pereiopods and in a proximal transverse band on outer surface of carpus of second walking leg. A patch of red chromatophores on inner side of terminal segment of antennal peduncle. First three pereiopods with a metallie green sheen dorsally on merus and carpus. Varying shades or blue, brown, and green in broken lines and blotches covering cara. pace and both ends of abdomen.

MEASURBMENTS (m.): Male from Sea Horse Key. Shleld, length 6.0 , width 6.2 ; carapace 11.0 , eyes 4.5 ; major chela, length 13.5, wiath 5.0 , dactyl 6.0 , minor chela, length 8.4 , width 3.2 , dactyl 4.5 ; third right perelopod, basis.ischium 3.8 ; merus 8.0 , carpus 6.0 , propodus 7.5 , dacty 13.3 .

\section{Pagurus Iongimanus $\mathrm{n} . \mathrm{sp}$.}

MATERIAL EXAMINED: Male holotype; off Cayenne, French Gulana, $05^{\circ} 57^{\prime} \mathrm{N}_{\text {., }} 52^{\circ} 20^{\prime} \mathrm{W}_{*}, 28.31 \mathrm{fms}$; Sept. 11, 1958 ; "Oregon" sta. 2307.

RANGE; Known only from type.

DIAGNOSIS: Byes stout and short. Major chela knife. like, longer than abdomen.

DESCRIPYION, Shield broader than long, flattened. Lateral teeth exceeding obsolescent rostrum. Byes short, heavy; expanded distally. Eye scales concave, triangular; 
subapical spinule minute. Antennular peduncle with terminal segment beginning at base of cornea. Antennal peduncle shorter, acicle equaling eye. Flagellum slender, nude, reaching major manus.

Right cheliped long, exceeding walking legs. Merus and carpus heavy. Dorsal surface of carpus covered with transversely lobed denticles; inner dorsal margin with a few strong dentieles interspersed with much smaller ones; outer margin evenly granular. Chela much longer than carpus, subequal in width, less than $t$ wo-thirds as thick. Dorsal surface low convex, feebly granular, with an even margin of united granules. Fingers flattened; cutting edges sharp, mainly of fine, calcareous teeth.

Minor chela missing. Walking legs slender, armed with dorsal crests of spinules on carpus; merus faintly crested. Dactyl slightly setose distally on dorsal and ventral angles; tips minute. Propodus of fourth pereiopods w1th a uniseriate rasp; propodus of fifth chelate, with rasp on distal half. Unpaired pleopods uniramus. Telson small, distal lobes finely spinulose in margtas.

COLOR, Eyes with black cornea; eyestalks, eye scales, shield, and peduncles of antennae and antennules with dark gray chromatophores beneath the surface. Major chela orange rufous in a broad dorsal stripe. Carpus of major chela mottled with ferruginous dorsally. Propodus of walking legs with latter color in three longitudinal stripes on suffused 


\section{0.}

background of same color.

MEASUREMENTS (mm.): Shleld, length 4.0 , width 5.0 , carapace 8.0 ; eyes 3.2 ; right chela, length 13.8 , w1dth 4.5 , dactyl 5.6, third right perelopod, basis-1schium 2.4, merus 6.2 , carpus 4.7 , propodus 5.7 , dactyl 10.2 .

\section{Pagurus operculatus (Stimpson)}

Eupagurus operculatus Stimpson, 1859, p. 92, pl. 1, r1gs. 9, 10.

Pagurus operculatus Gordan, 1956, p. 333.

MATERIAL EXAMINED: Key Largo, Fla., Carysfort Light; Aug. 14,1948 ; D. Moore and P. Lyman; 1 male.

RANGE: Florida Keys and Tortugas Ids.

DIAGNOSIS: Najor cheliped unusually heavy and broad, forming an operculum by itself. Minor chela no heavier than walking legs. Major chela nearly as broad as long, granular on face and very white.

DESCRIPTION; Shleld glabrous, with a few minute setae. Cardiac plate broad. Eyes short, moderately dilated at cornea, curved out and with a row of setae in four tufts above; a fifth tuft on Inner surface. Eye scales narrow, margins raised, subapical spinule very minute. Antennular peduncles equaling those of antennae and exceeding eyes. Flagellum slender, nude, equaling major cheliped.

Right cheliped exceeding walking legs, greatly swollen 
In merus, carpus, and chela. Carpus armed with a few spin. ous denticles on Inner margin; face sparsely granular with outer margin a fine line of granules. Major chela with face IInely granular; margins produced upward and outward, edges scalloped. Dactyl short, somewhat subchelate, with a beaded dorsal ridge.

Minor cheliped feeble; just reaching major chela. Carpus armed with flve dorsal spines and one distoventral. Chela narrow, 11ttle longer than carpus. Walking legs glabrous, nearly nude; carpus with a distodorsal spine. Dactyl short, with six corneous spines on ventral angle. Claws strong, curved downward. Fourth perelopods with a single row of scales in propodal rasp. Telson subsymetrical, with straight spinules on inner margins of distal lobes. MEASURAMEITS (mm.): shleld, length 5.0, width 5.0 , carapace 8.5 , eyes 3.8 , major chela, length 7.9 , width 7.8 , dactyl 4.3; minor chela, length 4.6, width 1.4, dactyl 2.5, third right perelopod, basisalsch1um 3.2, merus 5.1, carpus 4.2 , propodus 4.8 , dacty 15.5 .

COLOR: Specimen in alcohol for 10 years. Lateral areas of shleld maculated with red and white. A white spot surrounded by red just behind each eye scale. Eye stalks with a red band midway except on ventral surface. Eye scales white except for a narrow margin of red at bases. Antennular peduncle with a broad red band on each of last two segments. Merus and carpus of major cheliped maculated with white 


\section{2.}

and red dorsally and laterally; spinules and denticles white. Major chela strikingly white above. Minor chela and walking legs unlform buff-orange with some white patching on mers.

REMARK: According to Provenzano (in 11tt.), who has examined the only female specimen taken, this species belongs in the genus Pagurus. However, Pagurus rosens Benedict, from the Gulf of California, which is very close to $\mathrm{P}$. operculatus, does belong in the genus Pylopagurus. Examination of additional females may show that operculatus also belongs in the latter genus.

\section{Pagurus politus (Smith)}

Eupagurus politus Sm1th, 1882, p. 12, p1. 2, fig. 5. Eunagurus smith11 A. M1lne Edwards and Bouvier, 1893, p. 140, pl. 10, 11gs. 1-12.

Eupagurus bouvier1 Faxon, 1895, p. 57.

Pagurus bouvier1 Gordan, 1956, p. 327.

Pagurus Dolitus Gordan, 1956, p. 333.

MATERIAL EXANINED: One hundred and thirty-four specimens from three general areas.

Ore Georg1a: Between $34^{\circ} 41^{\prime}-33^{\circ} 31^{\prime} \mathrm{N}$., and $75^{\circ} 31^{\prime-}$ $76^{\circ} 35^{\prime}$ W.; 180-230 Ims.; June 14-16, 1957; "Combat" stas. $356-369$; 10 males, 2 females ( 1 ovig.).

Off Northeast Florida: $30^{\circ} 32^{\prime} \mathrm{N},, 90^{\circ} 19^{\prime} \mathrm{W}_{.3} 23 \mathrm{fms}, 3$ 
Jan. 10, 1957; "Combat" sta. 201, I male in shell of slpho stimpsons. $29^{\circ} 55^{\prime} \mathrm{N} ., 80^{\circ} 10^{\prime}$ W.; 180-220 fms.; Dec. 5, 1956, "Combat" stas, 185-7, 4 males, 5 females (2 ovig.). $29^{\circ} 48^{\prime} \mathrm{N}_{0}, 80^{\circ} 12^{\prime}$ W.; 130 fms.; Sept. 1, 1956, "Combat" sta. 82,21 males, 9 females. $29^{\circ} 36^{\prime}$ N., $80^{\circ} 07^{\prime}$ W.; 210 Pms.; Sept. 12, 1957; "Combat" sta. 501; 2 males from Scaphella gould1ana: $29^{\circ} 34^{\prime} \mathrm{N} ., 80^{\circ} 23^{\prime} \mathrm{W} . ; 25$ fms.; June 2, 1957; "Combat" sta. 349; 5 males (1 with gooseneck barnacle attached to shield). Between $30^{\circ} 04^{\prime}-29^{\circ} 1^{\prime} \mathrm{N} .$, and $80^{\circ} 13^{\prime}-80^{\circ}$ O5' W.; 135-220 fms.; Nov. 20-25, 1957, "S1Iver Bay" stas. 212-230, (51 spec1mens from 14 stat1ons), 35 males, 16 females $\left(7\right.$ ovig.). $28^{\circ} 56^{\prime} \mathrm{N} ., 80^{\circ}$ ol' W. 100 Ims.; Mar. 29, 1940; "Pellean" sta. 204-4; 1 ovig. female. $28^{\circ} 08^{\prime} \mathrm{N}_{.}, 79^{\circ} 54^{\prime} \mathrm{W}_{. ;} 100 \mathrm{fms.;}$ Mar. 30, 1940, "Pelican" sta. 205-5; 1 remale.

South Florida and Tortugas: $25^{\circ} 12^{\prime} \mathrm{N} ., 80^{\circ} \mathrm{00}$ ' W. 185 fms.; July 25, 1957, "Combat" sta. 453; 5 males, 1 female. $25^{\circ} 04$ ' N., $80^{\circ}$ 02' W.; 180 Ims.; July 22, 1957; "Combat" sta. 440; 2 males. $24^{\circ} 13^{\prime} \mathrm{N} ., 81^{\circ} 42^{\prime}$ W.; 300 fms.; July 21, 1957, "Combat" sta. 436, 4 males, 2 fomales. $24^{\circ} 33^{\prime} \mathrm{N} ., 83^{\circ} 34^{\prime}$ W.; 200-300 Ims.; July 9, 1955; "Oregon" sta. 1328,1 male, 1 female. $24^{\circ} 28^{\prime} \mathrm{M} ., 83^{\circ} 29^{\prime} \mathrm{W}_{0}, 220$ Ims.; June 15, 1956, "Oregon" sta. 1541; 1 male, $24^{\circ} 28^{\prime}$ N., $83^{\circ} 28^{\prime}$ W.: 210 fms.; June 16, 1956, "Oregon" sta. 1543; 1 male, I female. South of Tortugas; $110 \mathrm{fms.;}$ July 15, 1930, W. I. Schmitt, 1 male; same area; 135-156 fms.; July 2, 1932, 


\section{4.}

W. L. Schmitt; 1 male, 1 ovig. Semale.

RANGE; Massachusetts to Straits of Florida and Dry Tortugas, 100 to $300 \mathrm{fms}$. In area studied $(25 \mathrm{fm}$, record doubtful), 55-365 Ims, of New England.

DIAGNOSIS, One of larger spectes in genus, up to six Inches including chelipeds, Latter armed only with short spines and numerous denticles.

DESCRIPTION: Shleld broader than long, rlattened; rounded lateral teeth exceeding blunt rostrum. Eyes shorter than shield, swollen at cornea; line or setae on dorsal surface from scale to recessed spot in cornea. Antennular peduncle short, exceeding eye by half of terminal segment. Antennal peduncle slightly exceeding eye, second segment with a minute spinule on inner angle and three or four on inner margin of outer projection. Flagellum equaling legs, nude.

Chelipeds not markediy different. Merus of major cheliped serrate on distodorsal margin; spinulose on distoventral outer angle. Dorsal surface of carpus covered with sharp denticles; latter form a row on inner margin. Chela covered with small, blunt denticles. Cutting edges typical; Pingers gaping except at tips. Carpus of minor cheliped with dorsal margins of sharp denticles evenly separated by a flat, glabrous strip. Latter narrowed distally by short row of four denticles next to outer margin. Minor chela dorsally triangular with apex of ridge extending to tip of 


\section{5.}

pollex. Denticles cover dorsal surface of palm and pollex, forming two prominent rows on proximal part of ridge. Cutting edge of pollex with fewer calcareous teeth than usual. T1p of dactyl covered completely by that of pollex when closed.

Second and third perelopods feebly armed with denticles on dorsal surface. Dactyls long, concave on proximal inner surface, flat triangular on remaining length. Ventral angle sharp, fringed with blunt, corneous spinules, fringe of longer, stiff setae, usually much worn, occurs on distodorsal margin. Distal, outward twisting apparently allows Inner surfaces to be used as walking surfaces.

Propodus of fourth perelopods with a ventral rasp four scales wide; very minute scales compose dactylar rasp. Propodus of fifth pereiopods with rasp covering upper two-thirds of distal half. Dactyl bears a dorsal rasp two seales wide; cup-shaped lower surface of dactyl fringed with a corneous comb of teeth which closes over a much smaller opposing comb. Unpaired pleopods of male with a small external ramus. Telson markedly asymmetric; armed with recurved, corneous spinules.

COLOR: General hue of salmon on first three pairs of perelopods, most intense on dorsal and lateral surfaces of merus of perelopods on right; more distal segments and left perelopods with more white in background, deepest color on leading edges of denticles. 


\section{6.}

MEASUREMENTS (m.): (Male from "S1lver Bay" sta, 230) Shleld, length 12, w1dth 14; carapace 25; eyes 9.5; major chela, length 30.5 , width 14 , dactyl 15; minor chela, length 24, width 9.5 , dactyl 14.5, third right pereiopod, basis1 sch1um 8.5 , merus 16.5 , carpus 14.5 , propodus 14.5 , dacty 1 28.

REMARKS: Milne Edwards and Bouvier described Eupagurus Smith11 from IIve female specimens taken in the Straits of Florida. While the measurements given by these authors indicate some differences in dimensions of the chelipeds, a comparison of certain ratios derived from measurements given for types of smithi1 and Dolltus with those from elght specimens taken off the eastern and southern coasts of Florida and south of the Tortugas indicate that this species varies greatig in this area. Ranges of these ratios are given in the following table.

$\begin{array}{llll}\text { Carapace/ } & \begin{array}{l}\text { Types of } \\ \text { smithi1 }\end{array} & \begin{array}{l}\text { Types of } \\ \text { Dolitus }\end{array} & \begin{array}{l}\text { Florida } \\ \text { Rolitus }\end{array} \\ \begin{array}{l}\text { Rt. chela } \\ \text { Length/w1dth }\end{array} & 1.04-1.03 & 0.87-0.95 & 0.86-1.06 \\ \begin{array}{l}\text { Carapace/ } \\ \text { Third dacty1 }\end{array} & 1.12-1.12 & 0.83-0.86 & 0.84-1.12\end{array}$

While the chelae of the smithil types are heavier than any others measured, the variation of $1.80-2.18$ in two specimens Prom "Oregon" sta. 1328, the same general area as the 
types were from, would seem sufflclent evidence for reducing smithi1 (equals bouvieri) to synonomy.

This species is the most abundant pagurid taken off the eastern coast of Florida in experimental trawling for Bvmenonenaeus robustus Smith. In the Gulf of Mexico its range apparently extends only to the Dry Tortugas.

\section{Pagurus pollicaris Say}

Pagurus poll1car1s Say, 1817, p. 162. --Behre, 1950, p. 22. --Gordan, 1956, p. 333.

Eupagurus Dollicaris St1mpson, 1858, p. 237.

Bupagurus flor1danus Bened1et, 1892, p. 5.

Pagurus elor1danus Behre, 1950, p. 22. --Wass, 1955, p. 152. --Springer and Bullis, 1956, p. 16. -Gordan, 1956, p. 329.

MATERIAL EXAMINED, Fifty-three males, 12 females, ten in shells, from the coasts of seven states.

Massachusetts: Nantucket, 1853, 2 large males, MCZ 521 (one w1th carapace length $23.5 \mathrm{~mm}$.).

South Carolina: $32^{\circ} 55^{\prime} \mathrm{N} ., 79^{\circ} 29^{\prime} \mathrm{W}, ; 5$ fms.; reb. 12, 1940, "Pelican" sta. 182-17; 3 in shells. Charleston, 1852, I male, $\mathrm{MCZ} 12801$.

Georgla: $32^{\circ} 00^{\prime} \mathrm{N}_{.}, 80^{\circ} 34^{\prime} \mathrm{W}_{.3} 8$ fms.3 Feb. 3, 1940, "Pelican" sta. $181-3,2$ in shells. $31^{\circ} 08^{\prime} \mathrm{N}_{*}, 81^{\circ} 05^{\prime} \mathrm{W}_{0} 3$ 7 Ims.; Jan, 31, 1940; "Pelican" sta. 178-3; I ovig. Pemale. Sapelo Id.; May 30, 1957, I male, 2 females; July 10, 1957; 


\section{8.}

6 males, 1 female; J. M. Teal.

Florida (east coust): $30^{\circ} 25^{\prime} \mathrm{N} ., 81^{\circ} 19^{\prime} \mathrm{W} .38 \mathrm{fms.3}$ Jan. 25, 1940; "Pellcan" sta. 176-1; 1 male, 1 ovig. female, 2 In shells. $28^{\circ} 24^{\prime} \mathrm{N} ., 80^{\circ} 33^{\prime} \mathrm{W}, \mathrm{fms}^{\prime}$, Apr. 4, 1940, "Pellean" sta. 207-3; 2 in shells.

Texas: Lydia Ann Channel; 6 males. Mud Id.; 1 male. Port Isabel, 1 male; H. H. H1ldebrand.

Loulstana: Isle of Brittain, mouth of Mississippi; "Rec'd. May 30, 1860, C. S. Plerce; 1 in shell, MCZ 1055. Alabama: Mobile; Apr. 1850, A. Agassiz; 1 ovig. female. Florida (west coast), Cape San Blas, 4 t: Ims, Feb, 1, 1956; "A. A. Jakkula", I ovig. Pemale, carapace length 6.3 mm., carrying about 1500 eggs, each .4 mm. In diameter. Sea Horse Key, south slde beach at low tide; Sept. 21, 1957; 20 males; grass flats; Oct. 8, 1957, 5 males, 2 females; Nov. 15, 1958; 6 males, 2 Pemales; D. Folks. Egmont Key; W. L. Coons, 1 male, USNM 997. Charlotte Harbor; W. H. Dall; 1 male, USM 12448, type of P. Ploridanus. Charlotte Harbor; 1850 ; 1 male, 1 ovig. Iemale; $\mathrm{MCZ} 470$.

RANGE: Massachusetts to Florida (Cape Canaveral); to 14 fms. (Cape Cod), Texas to west coast of Florida (exact limits not known but apparently not found at Key West or Dry Tortugas); to $4 \frac{1}{2}$ fms.

DIAGNOSIS: Chelipeds heavy, right much larger than left. Chelae nude; faces covered with low peaked denticles varying in size and more or less separated. Dorsal and 


\section{9.}

Inner surfaces of palm and chela form an obtuse angle.

DESCRIPTION: Shleld small, shorter than cardac portion. Rostrum subequal to lateral teeth. Eyes little shorter than shield; a little thicker at cornea than at bases, narrowed in midsection. Peduncle of antennule exceeding eyes by half of distal segment, that of antennae exceeding by a fourth. Aclele unarmed, reaching cornea. Flagellum nude, equaling perelopods.

Merus of major chela armed with six spines on distal margin; carpus with short, blunt spines on inner dorsal margin. Remaining dorsal surface of carpus w1th sparse setae partially obscuring 1rregular rows of dent1eles. Chela w1th an outer margin of strong teeth in somewhat serrate outer margin. Inner margin raised, supporting irregular dentieles w1th round bases and blunt tips. Dorsal surface covered thickly with similar denticles, rounded on palm, polygonal and more closely spaced on fingers.

Minor chellped armed on carpus with strong dentieles in two 1rregular rows above. Chela w1th strong blunt teeth on outer margin, many short denticles on inner angle of palm. Dorsal surface as in major member. Dactyl with two rows of even, round denticles along median margin.

Carpus of flrst walking legs with several spines on dorsal erest; propodus of flrst and carpus of second with sharp denticles above. Dactyl comparatively slender and long. Propodus of fourth perelopods with slx rows of scales in rasp. 
Telson subsymmetrical, eringed with sharp spines on triangular distal lobes.

COLOR: Fresh specimens from Sea Horse Key, Fla. Body and perelopods peppered with prune purple. Same color on eyestalks behind navy blue corneas. Setae on antennular flagellum with a subproximal line of flaming maple which diffuses on elther side. Lavender in varying intensity in denticles on faces of chelae. Flaming maple outines denticles bordering cutting edges of fingers.

MEASUREMENTS (mm.): Male from Sea Horse Key. Sh1eld, length 11.5, w1dth 11.7 ; carapace 24.03 eyes 9.5 , major chela, length 24.0 , widh 15.5 , dactyl 11.7; third right perelopod, basis-1schium 8.5, merus 13.4, carpus 11.5 , propodus 11.5, dacty1 21.7.

REMARKS: Benedict described P. Llorldanus from spec1mens taken on the Gulf coast of Florida, stating that the hands were much narrower than in pollicaris. Rat1os of w1dth over length of major chela in 13 specimens from Massachusetts, Charleston, and Sapelo Id. show a range of .61 to .73 , while ratios of the same measurements in 15 specimens from Texas, Loulsiana, Alabama, and the west coast of Florida range from .54 to .74 . This wide varlation in specinens from both areas seems sufficient evidence, along with observed variation in the points mentioned by Benedict, to place Lloridanus in synonomy. This is one of several species which apparently have a discontinuous 


\section{1.}

distribution around the t1p of Florida.

\section{Pagurus rotundimanus $n$. sp.}

MATERIAL EXAMINED: Twelve speclmens from two localities.

Der Tortuges: Holotype, male, $24^{\circ} 20^{\prime} \mathrm{N} ., 83^{\circ} 20^{\prime} \mathrm{W}_{\cdot 3}$ 190 fms.; Apr. 13, 1954; "Oregon" sta. 1005. Allotype female (ovig.); $16 \mathrm{m1}$. south of Tortugas; $197 \mathrm{fms.3}$ Aug. 1, 1932; W. L. Schmitt. All other specimens are designated paratypes. 140-197 fms.; Aug. 1, 1932; W. L. Schmitt; 3 males, 2 ovig. Pemales. 153-158 fms.; July 22, 1931; W. L. Schmitt, 1 male, 1 ovig. female. 17 m1. south, 135-156 fms.; July 2, 1932; W. L. Schmitt; 1 ovig. Pemale, 205-221 Ims.; July 3, 1931, W. L. Schmitt; 1 juv, male from flsh stomach. Bahamas: 360 fms.; May 10, 1939; "Atlant1s" sta. 3476, 1 dried male, MCZ 126694.

RANGE: Straits of Florida; $156-360 \mathrm{fms}, 3$

DIAGNOSIS: Small species. Cornea swollen, antennal flagellum equaling pereiopods. Armed only on carpus of major chellped. Major chela moderately swollen.

DESCRIPTION: Carapace smooth, evenly rounded, anterior projections equal. Eyestalks short, cornea swollen. Bye scales narrowed, subapical spines strong. Terminal article of antennular peduncle begins at base of cornea. Antennal peduncle slightly exceeding eye, acicle subequal; 1lagellum nude, equaling perelopods. 


\section{2.}

Major cheliped sparsely setose. Merus with a spinule marking each distoventral angle. Carpus with ten or more spinules on Inner dorsal angle. Margins of chelae feebly marked, inner margin a beaded line of granules. Minor cheliped equaling major. Carpus with dorsal margins of short spinules. Chela with median dorsal ridge of denticles extending to gape. Fingers long.

Carpus of walking legs with a distodorsal spinule or denticle. Dactyls slender, twisted, with stiff setae on distal margins. Propodal rasp of fourth perelopods a single row of scales. Telson long, bifid, with two recurved spinules bordered by denticles on each distal lobe.

COLOR, Holotype, in alcohol four years, st111 shows broad, light red bands on mer1 and propodi of walking legs, distally on merus of major chela and proximally on carpus.

MEASUREMENTS (mm.): Holotype male, Shield, length 4.0 , width 4.1 , carapace 6.6 , eyes 3.0 , major chela, length 8.2 , width 3.2 , dactyl 3.8 , minor chela, length 6.9 , width 1.7, dacty 4.1 , third right perelopod, basis-1schium 2.9, merus 5.4 , carpus 3.4 , propodus 5.5 , dacty 18.0 .

\section{Pagurus rubrolineatus $n$. sp.}

MATERIAL EXAMINED; Male holotype; western edge of Rosalind Bank, Caribbean Sea, $16^{\circ} 35^{\prime}$ N., $80^{\circ} 55^{\prime}$ W. 100 fms.; Sept. 24, 1957; "Oregon" sta. 1890; found in shell of 
Pholium granulatum Born.

RANGE: Known only from the type.

DIAGNOSIS: Dorsal surfaces of carpus and propodus of chelipeds armed with a thick covering of short spines. Striking color pattern of red lines occurs on walking legs. Antennal Ilagellum slightly exceeds perelopods.

DESCRIPTION: Shleld broader than long; Prontal margin a thin raised line between sharp-spined lateral teeth; latter easily exceed blunt rostrum. Shallow grooves extend posterlorly from lateral teeth. Cardac plate very narrow, poorly calcified; g1ll cover membranous.

Eyes shorter than shield, moderately swollen distally. A few stout setae rise from four punctae on inner dorsal surface of eyestalks and from a flfth on inner ventral surface. Eye scales typical of genus, w1th a minute subapical spine. Antennular peduncle exceeds eye by half of terminal segment. Base of antennal peduncle bears a lateral spinule, second segment with a spinule at inner angle, flve ranging from minute to strong on inner surface of outer projection, terminal segment exceeds eye by one-half. Acicle strongly setose, exceeding eye by terminal spine. Flagellum with a few fine setae, exceeding pereiopods.

Major cheliped bears four spines on anterodorsal margin, four more on inner ventral angle. Dorsal surface of carpus and chela armed with closely spaced spines on dorsal surfaces; with a row of nine stronger spines on inner dorsal margin of 


\section{4.}

carpus, a row of 20 on outer edge of propodus. Cutting edges of fingers composed of irregular, calcareous teeth; largest tooth on pollex located about three-fourths of d1stance from apex of gape. Dactyl has a few corneous scales between last calcareous tooth and corneous tip. Outer ventral surface of chela denticulate, denticles largest near margin; Inner surface presents a few crested ridges of varying length.

Distodorsal angle of merus of minor cheliped armed with three sharp spines; outer ventral margin with elght spines, remainder with denticles. Dorsal surface of carpus with several strong splnes, that of propodus with numerous spines on outer dorsal surface, denticles on inner surface. Fingers with cutting edges on distal half; teeth corneous on dactyl, evenly spaced and calcareous with intervening corneous scales on pollex.

Walking legs equal major cheliped; merus of first armed with two distodorsal spines, that of second with one spine. Dactyls of both legs present ventral and dorsal rows of corneous spinules which are stronger and more numerous near long corneous claws. Propodus of fourth perelopods with usual strong row of corneous scales on ventral margin; dactyl with a rasp of minute scales, and a denticle flankIng base of long, stralght claw. Chelate fifth perelopods with a rasp on distal half of propodus. Unpalred pleopods with a thumblike external ramus. Distal plates of telson 
asymmetrie, right larger; both triangular and armed with ten fine spinules on inner edges.

COLOR, Shleld specked with red. Mer1 of first three perelopods with a transverse band of red bordering anterior margins laterally except at dorsal angle, where it forms a v. Walking legs with narrow red line running from outer, ventral terminus on merus of each leg almost to tip of dactyl. Another line appears halfway between first line and dorsal crest on carpus and continues along dorsal crests of propodus and dactyl on each leg. Some fine red specking appears on chelipeds.

MEASUREMENTS (m.): Shleld, length 8.2, w1dth 8.7; carapace 13.5 ; eyes 6.1 ; major chela, length 16.5 ; width 9.3; dacty 18.0 ; minor chela, length 11.8 , width 4.7 , dactyl 7.0 ; third $1 e \mathrm{~g}$, basis-1schlum 6.0 , merus 8.2 , carpus 7.3 , propodus 8.5 , dactyl 12.0 .

\section{Pagurus schm1tt1 n. sp.}

MATERIAL BXAMINED: Twenty-one specimens from sixteen stations.

Holotype female; south of Tortugas, 79-140 fms.3 July 2, 1932; W. L. Schmitt. Allotype Pemale; Key West, Fla.; 110 fms.; J. B. Henderson.

All additional specimens are designated as paratypes.

Georg1a: Between $34^{\circ} 41^{\prime}-33^{\circ} 31^{\prime} \mathrm{N}$, and $75^{\circ} 31^{\prime}-76^{\circ}$ 35 ' W.; 180-230 Ims.; June 14-16, 1957; "Combat" stas. 356- 
369 ; I male.

Florida: $24^{\circ} 22^{\prime} \mathrm{N} ., 81^{\circ} 581 \mathrm{~W}$; 98 Ims.; Feb. 14, 1902; "Fish Hawk" sta. 7279; 3 Pemales (2 ovig., I juv.), 1 male. 16 mi. south of Tortugas; 65-125 fms.; W. L. Schmitt, 1 male In Phallum shell. Off Garden Key, Tortugas; May, 194l; J. R. Miller; 1 Pemale.

The following specirens from the Bahamas and Cuba were taken by the "Atlant1s".

Bahamas: $26^{\circ} 08^{\prime} \mathrm{N} ., 79^{\circ} \mathrm{O} 2^{\prime} \mathrm{W}_{.3} 155 \mathrm{fms.;}$ Fob. 3, 1938 sta. 2951 ; 1 ovig. female.

Cuba: $22^{\circ} 47^{\prime} \mathrm{H} ., 78^{\circ} 49^{\prime} \mathrm{W}_{\text {.; }} 210 \mathrm{fms}, \mathrm{s}$ Mar. 10, 1938; sta. 2981-B; 1 male. $22^{\circ} 47^{\prime} \mathrm{N} ., 78^{\circ} 49^{\prime} \mathrm{W} . ; 195$ fms.; Mar. 10,1938 ; sta. $2981-C_{3} 1$ ovig. female. $22^{\circ} 48^{\prime} \mathrm{N},, 78^{\circ} 50^{\prime}$ W.; 210 fms.; Mar. 11, 1938; sta. 2982-A; 1 male (carapace length $25 \mathrm{~mm}),$.1 ovig. female. $22^{\circ} 47^{\prime} \mathrm{N} ., 78^{\circ} 48^{\prime} \mathrm{W}_{.}, 205^{-}$ 230 fms.; Mar. 11, 1938; sta. 2982-B; 1 male, 1 ov1g. female. $22^{\circ} 38^{\prime} \mathrm{N}_{.}, 78^{\circ} 25^{\prime} \mathrm{W} . ; 235 \mathrm{fms}$, Apr. 28, 1939, sta. 3405, 1 male. $22^{\circ} 42^{\prime} \mathrm{N}_{.}, 78^{\circ} 39^{\prime} \mathrm{W}_{. ;} 200 \mathrm{fms.3}$ Apr. 29, 1939; sta. 3407, 1 male.

Gulanas: $09^{\circ} 41^{\prime} \mathrm{N} ., 59^{\circ} 47^{\prime}$ W.; 150 fms.; Nov. 3, 1957; "Oregon" sta. 1985, I male, 1 female. $07^{\circ} 26^{\prime} \mathrm{N} ., 54^{\circ} 49^{\prime} \mathrm{W}_{0}$; Sept. 8, 1958, 1 female from Murex shell. $07^{\circ} 27^{\prime} \mathrm{N} ., 54^{\circ} 27^{\prime}$ W., 120-135 fms.; Sept. 9, 1958, 1 ov1g. female.

RANGE: Georgla to Surinam; 85 to $235 \mathrm{fms}$.

DIAGNOSIS: Faces of chelae armed with 1rregular rows of short spines. Dactyl of minor chela unusually long, hinged 
near base of propodus; two rows of granules on dorsal surface.

DESCRIPIION: Shield smooth, with stiff setae near frontal margin and posterior to lateral teeth at two polnts on each side of gastric area. Rostrum and lateral teeth each tipped with a sharp spinule. Posterolateral plates narrowed at each ond. Cardiac plate a narrow strip with adjacent calc1fled areas. G1ll covers transparent.

Eyes $1 \frac{1}{2}$ times as broad at cornea as at base; cornea large, black. Eye scales typical of genus, slightly concave dorsally and with a subapical spinule. Terminal segment of antennular peduncle begins at midlevel of cornea. A sharp, curved spinule located posterolateral to base of each antennal peduncle. Second segment with a sharp spinule at Inner angle, outer projection triangular, spine-tipped. Terminal segment exceeds eye by at least a third. Acicle slightly exceeds eyes long setae in dorsal edge, spine at t1p. Flagellum exceeds pereiopods; minute setae appear at each articulation, a few long setae at considerable intervals. Major cheliped with six stout spines on anterodorsal edge of merus. Surface of carpus covered with transverse, scale-like rows of short setae; Inner dorsal margin armed with 14 spines, three more on distal edge. Marginal setae long. Propodal surface protected by numerous stout spines. Pollex with an outer, marginal row of corneous-tipped spines; dactyl with a dorsal and a dorsolateral row of similar, blunt 
spines. Proximal two-thirds of cutting edges of eingers composed of long, blunt, calcareous teeth, fingers meeting only on distal half contacting edges beginning with a large calcareous tooth on pollex and an equal, more distal one on dactyl. Intervening space to tips set with rounded, calcareous teeth on pollex, minute, corneous denticles on dactyl. Surface of chela between spines covered with short setae. Minor cheliped about half as strong as major, reaching to halfway point on dactyl of larger member. Merus with two small, anterodorsal spines; ventral margins unevenly armed with strong denticles. Dorsal surface of carpus bears four spines in row behind broad notch in anterior margin, with two smaller spines on each side of notch. Propodal surface covered with spines and short setae. Dactyl unusual1y long, articulating with propodus well behind gape proper; surface marked only by two low, beaded ridges. Outer margin with a fringe of long setae. Cutting edges meet only on distal half. Cutting edge of dactyl composed of corneous scales entirely; that of pollex consists of calcareous teeth more widely spaced distally, with corneous scales f1lling the spaces. Tips of fingers amber-colored, corneous; round tip of dactyl closing under flat tip of pollex. Fringe of long setae borders outer edge of chela.

Walking legs equal major chel1ped. Dorsal crest of carpus of first armed on forepart with five spines; that of second walking leg with four smaller, more distal spines. 
Numerous strong setae on dorsal surfaces of both walking legs, 1ncreasing in size and number distally. Dactyl with a shallow, longltudinal groove on each side; tips long, corneous.

Propodus of fourth perelopods with a uniseriate rasp of about 20 broad scales on distal two-thirds of ventral margin; rasp of stout dactyl composed of minute scales. Propodus of flfth pereiopods covered by a rasp on distal half of outer surface. A pair of anterior pleopods present on female; latter carrles at least $5,000 \mathrm{eggs}$, each $0.5 \mathrm{~mm}$. in diameter. Male pleopods small, external ramus a minute, translucent projection. Telson quite symmetrical, terminal lobes produced at outer edge; distal median cleft a broad V armed with a solld row of short, ealcareous teeth.

COLOR: Specimens from "Oregon" sta. 1985 after s1x months in alcohol. A general hue of apricot on the followIng parts: Eyestalks, merus of chelipeds lateraliy and in a broad transverse band above and along distal margin, carpus and chela of chelipeds, and on walking legs except for a white band behind anterior margins of merus.

MEASURENEIYS $\left(\mathrm{mm}_{\bullet}\right)$, Holotype female, Shleld, length 7.7 , width 7.5 ; earapace 13.5 , eyes 5.8 , major chela, length 15.4, width 8.2 ; dacty 8.0 ; minor chela, length 12.5 , width 5.4, dactyl 9.5; third right pereiopod, basis-1schium 6.5, merus 9.6 , carpus 7.3 , propodus 9.0 , dacty 14.5 . REMARKS: While the presence of an anterior pair of 
pleopods in all females from the northern part of the range would call for placement of this species in a different genus, the absence of paired pleopods in females from Gulana makes the actual status of the species doubtrul. In the absence of other differences the specimens from the two areas are here considered to belong to the same species. Since the evolutionary tendency seems to be a reduction of parts, the most logical solution seems to be to place the species in the genus Pagurus.

Pagurus stimnsoni (Milne Edwards and Bouvier)

Eunagurus stimpson1 Milne Edwards and Bouvier, 1893, p. 146, 11gs. 19-25.

Pagurus stimnsoni Gordan, 1956, p. 335.

MATERIAL EXAMINED: Off Panama City, Fla.; 15 fms.; July, 1958; Ne1l C. Hulings; I male, I ovig. female. RAIGE; Off Panama C1ty, Florida.

DIAGNOSIS, Corneas very little d1lated. Major chellped armed w1th two rows of strong spines on inner border of carpus, five spines on Inner margin of hand. Dactyls of walking legs slender.

DESCRIPIION: Shleld smooth on gastric region; anterior projections little marked. Eyes subequal to shield, little swollen at cornea; minute setae stem from three spots on inner dorsal part of stalk. Eye scales broady oval, with a 
small terminal spinule. Antennular peâuncle exceeding eyes by half of terminal segment, that of antennae little longer than eyes. Flagellum equaling perelopods, nude; articles moderately long.

Major chellped exceeding minor; well armed on Inner dorsal margin. Merus armed on distoventral angles with strong spinules, two on outer angle and one on 1nner; a single aistodorsal spinule. Carpus with 15 spines in two rows on inner dorsal angle. Chela armed with five strong spines on inner dorsal margin of palm; outer margin marked by a line of fine teeth. Dorsal surface otherwise smooth, sparsely setose. Fingers present two strong teeth on dactyl, one on pollex fitting behind first on dactyl.

Minor chellped narrow; carpus armed with several spines in two dorsal rows. Outer dorsal angle of chela with seven spinules, lingers long. Walking legs slender, unarmed, sparsely setose. Dectyl more slender than propodus, w1th a few corneous spinules ventrally; claw long, fine. Propodal rasp of fourth perelopod with three rows of scales. Telson with angular distal lobes terminated by a recurved spinule; finely toothed on median margins.

COLOR: After eight months in alcohol, faint red markings persist in the following places: A broad band on cerpus of chelipeds; Inner surface of palm of major chela; a fine, longltudinal line on face of dactyl. Walking legs with two narrow stripes on outside of merus, carpus, and 
propodus. Faint patches of color connect these lines in the center of each segment.

MEASURgMenTs (mm.), Male from Panama City. Shield, length 2.0, width 2.0, carapace 3.2 , eyes 1.7 , major chela, length 4.3 , width 2.1 , dactyl 2.0 , third right perelopod, bas1s-1sch1um 1.0, merus 2.2, carpus 1.8, propodus 2.6, dacty1 3.7.

REMARKs: The holotype male could not be located at the MCZ. This species is quite variable in the armament of the chelipeds. It $1 \mathrm{~s}$ closest to Paguxus brevidactrlus Stimpson but can be separated from that species by the row of strong spines on the inner dorsal surface of the right palm.

\section{Pagurus tenuidectrlus n. sp.}

MATERIAL EXAMINED: Holotype male, MCZ $126686_{3} 22^{\circ} 34^{\prime}$

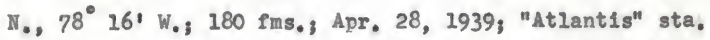
3397.

RANGE: Known only from type local1ty, off Cayo Coco, Cuba.

DIAGNOSIS, Carapace and head appendages largely typical of the genus. Terminal segment of antennular peduncle slightIy exceeds shield length. Antennal flagellum reaching approximately $14 \mathrm{~mm}$, beyond tips of legs. Chelipeds armed with spines on Inner dorsal margin. Dactyls of walking legs very slender. 
DESCRIPTION: Shleld heart-shaped laterally, smooth and plat on median surface; gastric region outlined by minute tufts of setae. Frontal margin uniformly raised between lateral teeth; latter marked by denticles and exceeding eveniy rounded rostrum. Cardiac plate translucent, broadened posterlorly; g1ll covers membranous.

Eyes little shorter than shield, slightly swollen proximally, greatly so distally. Eye scales slightly concave above, with a terminal spine. Antennular peduncle exceeds ejes by terminal segment. Second segment of antennal peduncle bears a spinule on inner angle, a stronger spine on outer angle; third segment with a spinule on inner angle; terminal segment exceeding eye by one half. Acicle slightly exceeds cornea.

Major cheliped with sharp denticles on lower margin of 1schium and merus, a spine at each anteroventral angle of merus and two more on anterodorsal angle. Carpus with six spines on inner dorsal margin, several scattered spinules toward outer side. A carpal spine protects outer articulating socket. Inner dorsal margin of propodus presents 15 short, curved spines; upper surface evenly rounded, with short, sparse setae. Outer margin indicated by slightly raised line. Dactyl has a few spinules on median margin. Fingers meet almost completely but without meshing closely, tip of dactyl passes beneath tip of pollex. Both finger and thutnb present about s1x low, calcareous teeth on cutting edges. 


\section{4.}

Minor cheliped has 1 schium and merus armed much as in the major member, carpus bears seven spines along inner margin, several spinules near outer margin. A few minute spinules appear on outer edge of palm. Dactyl bears a row of stiff setae on median dorsal surface. Setose pubescence occurs on most surfaces. Fingers elose throughout; cutting edges of Iine, corneous teeth, with those on pollex reinforced by small, calcareous teeth at varying intervals.

Second perelopods present $\mathbf{s 1 x}$ small spines on dorsal margin of carpus, the strongest placed anteriorly. Carpus of third perelopods with one or two anterodorsal spines. Propodus of both walking legs with corneous spinules on distal margin of lower median surface. Dactyls bear two rows of coarse setae directed medially from upper and lower surfaces. Short corneous tips of dactyls undifferentiated in color and shape.

Propodus of fourth perelopods with a single row of 15 prominent scales on distal four-fifths of ventral margin. Dactyl slightly shorter than propodus, w1th very IIne scales on distal half of ventral surface. Subchelate propodus of I1fth perelopods with a distal rasp on less than half of outer surface. Sternal plate separating third maxillipeds broad, unarmed. Telson widely blfid; each lateral plate armed distally with four curved spines.

MEASUREVENTS (mm.): Shleld, length 3.4, width 3.8 , carapace length 5.6 , eyes 2.8 ; major chela, length 7.0 , 
widh 3.6, plngers 3.3; third leg, basis-1schium 2.5, merus 4.0 , carpus 2.5 , propodus 5.2 , dacty 16.3 .

\section{Genus Paranacurus Sm1th}

\section{Peranagurus pllosimanus Smith}

Parapagurus p1losimanus Sm1th, 1879, p. 51. -Gordan, 1956, p. 338. --Springer and Bul11s, 1956, p. 16.

Eunagurus Lacob11 A. M1lne Edwards, 1880.

Pagurus p1losimanus W1111amson, 1915.

Paguris 1acop11 Gordan, 1956, p. 331.

MATERIAL EXAMINED, Three speeimens from two stations.

Florlca: $24^{\circ} 35^{\prime} \mathrm{N} ., 79^{\circ} 58^{\prime}$ W.; 565 fms.; July 25, 1957; "Combat" sta. 452, 2 males.

Nearagua: $12^{\circ} 25^{\prime} \mathrm{N} ., 82^{\circ} 23^{\prime} \mathrm{W}_{0} ; 400-425 \mathrm{fms}, 3$ Sept. 11, 1957; "Oregon" sta. 1907; 1 male.

RANGE; Found in most of the major oceans and seas; 250 to $640 \mathrm{Pms}$.

DIAGNOSIS: Byes reduced, about half as long as shield. Antennal plagellum nude, hals again as long as walking legs. Chelipeds covered with short, p1lose halr. Walking legs exceoding major cheliped. Abdomen reduced, usually housed in an anemone.

DESCRIPTION: Shleld wider than long, broadest at middle. Margin of front angled back from blunt rostrum. Cardie plate narrowed poster1orly, shorter than shleld. 
Eyes exceeded by last two segments of antennular peduncle. Bye stalks with a dorsal row of dense halr. Bye seales spiniform, feeble.

Major chela much stronger than minor. Walking legs slender, long, nude except for short, stife setae on dactyl, setae form a solld row near tip of dactyl.

COLOR, Specimen in formalin four months. Body and appendages cream, dactyls of walking legs buff with scarlet setrae.

MEASUREMENTS (mm.): Shleld, length 11.5, width 12.5; carapace 18, eyes 5.2 , right chela, length 22 , width 10 , dactyl 11.5; left chela, length 12.5 , width 5 , dactyl 7.5 , third right perelopod, basis-1schium 9.5, merus 18.5, carpus 10.5 , propodus 20.5 , dactyl 30 .

\section{Genus Prlonaguropsis Alcock}

\section{Pylonaguronsis atlantica $\mathrm{n}, \mathrm{sp}$.}

MATERIAL EXAMINED: Holotype male, allotype female (ovig.), paratypes, 21 males and 18 females (9 ovig. or recently so); $07^{\circ} 25^{\prime} \mathbb{1 1}$., $54^{\circ} 35^{\prime}$ W.; 75-80 Ims.; Sept. 8, 1958; "Oregon" sta. 2289.

RANGE: Type locality, off Surinam.

DIAGivosis: Right chela massive, much larger than left. Female with a pair of appendages on first segment of abdomen, four unpaired pleopods following; male with only three un- 
palred pleopods. G11l pa1rs 13; fllaments narrow.

DESCRIPTION: Shield well calelfled, smooth; rostrum exceeding lateral teeth. Cardac plate broad, membranous. Eyes moderate, slightly swollen at bases and cornea. Eye scales long, trlangular, sharp-tipped. Antennular peduncle exceeding eyes by less than half of terminal segment, antennal peduncle shorter, acicle equaling eyes. Flagellum strong, exceeding perelopods; feebly setose.

Najor cheliped heavy, as long as body, almost nude. Merus with high dorsal ridge, spines and denticles on inner ventral angle. Carpus with two rows of denticles on dorsal ridge; outer margin shelf-11ke. Propodus subchelate, articulating obliquely with carpus; thus heavy dactyl opens somewhat obliquely but not vertically. Dorsal surface granular to denticulate; outer margin heavy, produced. Cutting edges with a broad median tooth on pollex f1tting a gap between two smaller teeth on dactyl. Teeth corneous near tip of dactyl. Under slde of chela appears hollowed out in midsection and inside outer margin.

Minor cheliped feeble, not reaching dactyl of major. A few spinules on outer distoventral margin of merus; dorsal ridge of stronger spines on carpus. Fingers long, bent downward. Walklng legs slender, sparsely setose dorsally. Merus with several short spinules on dorsal angles. Propodus and dactyl wore or less grooved on outer sldes. Dactyl presents many flexible spinules on inner surfaces. 
Propodal rasp about four scales wide on fourth pere1opods; P1fth with rasp on distal two-thirds. Broad sternal plate between third maxillipeds with median suture flanked by a minute denticle on each side. Paired anterior pleopods of female feeble. Female with most eggs carries about 350 , each about $0.6 \mathrm{~mm}$. In diameter. Male pleopods biramous, a patch of setae near base of second. Narrow calcareous margin of telson finely serrate along shallow distal cleft. COLOR: Shleld generally rose with light stripes behind rostrum and lateral teeth. Eye scales outlined with scarlet anteriorly. Antennal rlagella with a searlet line on each side. Perelopods peach red dorsally to pink ventrally, I1berally specked with red. First of posterior abdominal plates rose colored.

MEASUREMENTS (mm.): Male holotype; shleld, length 7.8, width 7.6, carapace 13.5; eyes 6.4, right chela, length 19.5, w1dth 11.7, dactyl 10.6; left chela, length 10.5, w1dth 3.2 , dactyl 6.8 ; third right pereiopod, basis-1schium 3.2 , merus 9.3 , carpus 6.4 , propodus 8.4 , dacty 12.5 .

\section{Genus Prlooagurus Milne Edwarås and Bouvier}

Shield rounded, glabrous; rostrum obsolescent. Eyes shorter than shield, dilated at cornea. Eye seales as in Pagurus, usually rather narrow triangular, subapical spine always present. Peduncles of antennules and antenna exceeding eyes; feebly armed. Antennal flagellum usually subequal 
to perelopods, nude or w1th a few longer setae.

Right cheliped much stronger than left; chela broad and usually covered with tubercles, forming an opereulum with ald of small, elongate left chela or by 1tself. Tubercles mushroom-shaped and usually adjoining. Walking logs strong, sparsely setose. Fourth perelopods with a propodal rasp usually consisting of about four rows of scales, un1seriate in a few species.

Outer maxillipeds with a spine on 1 schlum lateral to serrate inner margin. Sternum separating these maxillipeds usually bidentate at midiline. Sternum separating coxae of third perelopods often supporting a projection, this and following sterna frequently with pecullar swollen hairs.

Female gonopods feeble. Telson deeply cleft at midine.

G111 pairs 11; similar to those of Pagurus.

The members of this genus are usually small forms. Nost of the specles are found at the edge of the shelf. The genus is predominantly new world; 15 specles are hereln 1isted from the Atlantic side and probably as many occur in the Paclfic. Two are known from southern Africa. The Pylopagurus exaulsetus of Boone (1927) is referable to Symnagurus arcuatus A. Milne Edwards and Bouvier.

\section{Prlonggurus}

1. Major chela not carried at an angle with carpus.......2. 
Major chela carried at right angle to carpus.........4.

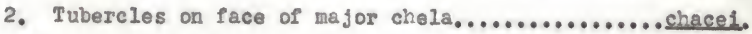
Face of major chela lacking tubercles..........andersoni.

3. Propodal rasp of fourth perelopods uniserlate........4. Rasp composed of at least 3 rows of fine scales.......5.

4. Face of chela smooth, lacking tubercles.....discoldalis. Face of chela with mushroom-11ke tubercles......rosaceus.

5. Tubercles on face of chela small, tipped with a sharp splnule......................................6.

Tubercles larger, not t1pped with sharp spines.......8.

6. A sharp spine rising from narrow space between third pair of coxae..........................ecrallinus.

Third pair of coxae more widely spaced; intercoxal projection not spinous..................... guianens1s.

7. A high, rounded boss in center of face of major chela, deep depressions on each side................h1spldus. Face not as 1rregularly sculptured...................

8. Face of major chela long, very concave......... cavimanus. Center of face as high or higher than margins.........9.

9. Tubercles separated, not interlocking to cover surface proper..................................10. Tubercles closely spaced, usually interlocking........11.

10. Tubercles large, widely spaced, with very 1rregular margins.................................erosus,

Tubercles more closely spaced, with minutely serrate borders................................boletlfer.

11. Tubercles of major chela with a projecting denticle above.................................. bartlett1. Tubercles lacking a dorsal denticle................... 12. Major chela lacking margins.............. glbbosimanus. 


\section{1.}

Major chela with margins of denticles or spines.......13.

13. Teeth in outer margin strong, 1rregular.......... alexandr1. Marginal teeth rather evenly serrate................14.

14. Blunt spines at proximal end of median dorsal ridge of palm, strong ridge on dactyl of chela, tiny specles.......

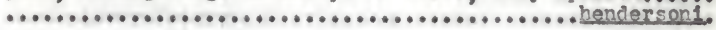

Dorsal surface of chela relatively smooth, medium-sized species. serratus.

\section{Pylopagurus andersoni n. sp.}

MATERIAL EXAMIMBD: Twenty-six specluens from four general areas.

Holotype male, allotype female (ovig.), 4 males and 2 Iemale paratypes; off Cape San Blas, Fla.; $29^{\circ} 28^{\prime} \mathrm{N}_{*}, 85^{\circ}$ 31' U.: 12 Ims.; Feb. 1, 1956; "A. A. Jakkula".

A11 of the following specimens are deslgnated as paratypes.

off North Carolina: $35^{\circ} 08^{\prime} \mathrm{N} ., 75^{\circ} 10^{\prime} \mathrm{W}_{.} ; 49$ fms. oct. 17, 1885; "Albatross" sta. 2956; 2 males. $34^{\circ} 381 \mathrm{~N}$., $76^{\circ}$ 12' W.; 18 rms.; Oct. 19, 1885; "Albatross" sta. 2607, 2 ovig. Pemales. $34^{\circ} 37^{\prime} \mathrm{N},, 75^{\circ} 40^{\prime} \mathrm{W}, 34 \mathrm{fms}$, Oet. 18 , 1885; "Albatross" sta. 2604; 2 ovig, females.

off South carolina: $32^{\circ} 52^{\prime} \mathrm{N} ., 78^{\circ} 59^{\prime} \mathrm{W} . ; 14 \mathrm{fms} .3$ Mar. 4, 1939; "Pellcan" sta. 182-23; 1 in shell. $30^{\circ} 341 \mathrm{~N} .$, $79^{\circ}$ 05' W.3 19 Ims.3 Mar. 9, 1940; "Pelican" sta. 194-10; 1 male.

Of Western Florida: $30^{\circ} 12^{\prime} \mathrm{N}, 86^{\circ}$ O1' W., 12 Ins. 


\section{2.}

Mar. 4, 1939; "Pelican" stas. 141-4, 1 ovig. female. $29^{\circ}$ $11^{\prime} \mathbb{N}_{.}, 85^{\circ} 29^{\prime} \mathrm{W}_{0} ; 26$ Pms.; "Albatross" sta. 2374; 1 male. $28^{\circ} 46^{\prime} \mathrm{N} ., 84^{\circ} 49^{\prime}$ W.; 26 fms.; Mar. 15, 1885; "Albatross" sta. 2406,1 male and 1 female. $28^{\circ} 45^{\prime} \mathrm{N} ., 85^{\circ} 02^{\prime} \mathrm{W}$. ; 30 Ims.; Mar. 15, 1885; "Albatross" sta. 2405, 1 male in shell of Turbo castanens. "Opposite Anclote R1ver"; Nov.Dec., 1900 ; J. B. Benedict; I female in sponge-covered shell, 1 in a long, conical shell.

Ore Southern Florida: $25^{\circ}$ o $4^{\prime} \mathrm{N} ., 82^{\circ} 59^{\prime} \mathrm{W} .324 \mathrm{fms} . ;$ Mar. 19, 1885; "Albatross" sta. 2413; 1 ovig. female. South of Loggerhead Key, Tortugas; June 19, 1925; W. R. Taylor; I male. Off Miami; 30 Ims.; May, 1912; J. B. Henderson; 1 male, "sponge dark maroon, crab red".

RANGE; North Carolina to northwestern Florida; 12-49 fms.

DIAGNOSIs; Walking legs longitudinally striped. Major cheliped heavy; dorsal surface of chela with numerous dent1cles, latter largest distally. Denticulate margins of right chela forming a serrate edge.

DESCRIPTION: Carapace glabrous, shield equaling cardac plate. Rostrum blunt, reaching base of eye scales, scarcely exceeding lateral teeth. Eyes shorter than shield, curved outward, cornea moderately swollen. Eye scales narrow triangular, with raised margins. Antennular peduncle exceeding eyes by half of terminal segment. Antennal peduncle slightly exceeding eyes; second segment with a minute 
spinule on inner angle, outer projection ending in a spinule. Aclcle sparsely setose, reaching midway on cornea. Flagellum finely bristled at each article, equaling pereiopods.

Right cheliped broad, massive, obscuring narrow left member. Merus with a small spinule on outer distal margin. Carpus armed on elevated lateral margins; on inner margin with a few small denticles behind a stout dent1cle above hinge. A strong denticle on inner margin below hinge, followed by numerous granules proximally. D1stodorsal margin stralght, with a few small denticles immediately posterior. Chela little longer than wide, tending toward subchelate. Pollex trlangular; fingers with blunt, caleareous tips. Propodal margins finely crenulate on outer margin, irregular on Inner, face with conical dentieles much larger distally. Dactyl with a marginal row of denticles forming a serrate Iine; a dorsal ridge of low, scale-like dent1cles. Entire cutting edge of dactyl closes under that of pollex. A fleshy fold protrudes ventrally between carpus and propodus. Minor chellped narrow, feeble. Carpus equaling chela, dorsal surface with a low, Inner ridge bearing three spinules and terminating in a distal spine, outer margin with only a distal spine. Ventrodistal, outer angles of both merus and carpus bear a spinule. Dorsal ridge of propodus leads to a spinule at bese of eutting edges; latter with only fine, corneous edges. Fingers spooned, with many tufts of fine setae on ventral and outer distal parts of elngers. 


\section{4.}

Walking legs most compressed in proximal and distal segments. Distodorsal angles of carpus armed with a spinule. Dactyl with margins bearing strong setae above, spinulose setae below; claws sharp. Rasp of fourth perelopods a ventral row of scales, of fifth a quadrate patch on outer distal hale of propodus.

Rounded boss appears between third pair of coxae, wide thin plate between fourth pair. Female gonopods small, 11ttle separated. Eggs on allotype number about 200 , each $.5 \mathrm{~mm}$. In diameter. Male pleopods falrly long, outer ramus a fourth as long as inner. Telson with a shallow median cleit; armed with calcareous spinules.

COLOR: (SpecImens from Cape San Blas after $2 \frac{1}{2}$ years in alcohol) Shield salmon with white near anterior margin and on 1rregular grooves running back from lateral teeth; a triangular red dot near posterior end of each white line. Front and edges of eye scales with fine red margins. Transparent, dlamond-shaped area covers cardiac reglon, with a red spot at each lateral angle. Eyestalks uniformiy aprleot, corneas black.

Merus of major chela with a wh1te dorsal angle bordered by salmon. Carpus eream colored above, with marginal ridges white; distodorsal margin with a fine red 1ine. Surface of chela similar to carpus, with denticles lighter, margins marked by pattern of alternating red and white. Red submarginal bands occur on inner surfaces of carpus and chela. 


\section{5.}

Four distal segments of legs with burnt orange longltudinal stripes tending to be broadest at midpoint of segments. Dactyl with same color in lateral grooves and as irregular blotches on remaining surface.

MEASUREMENTS (m.): Male holotype: shleld, length 3.5 , wiath 3.6 ; carapace 6.6 , eyes 3.2 ; major chela, length 8.2 , w1dth 6.0 , dactyl 4.2 , minor chela, length 3.8 , width 1.4, dactyl 2.3, third leg, basis-1schlum 2.7, merus 3.8 , carpus 2.5 , propodus 4.0 , dactyl 5.7.

REMARKS: Th1s specles bears a close resemblance to Pagurus onerculatus (Stimpson) although the color pattern In Presh material is quite different. However, Provenzano (In $11 t t_{.}$) reports that the only female over collected of the latter species lacks an anterlor palr of pleopods characteristic of the genus Pylonagurus. Both specles usually exhiblt a characteristic fleshy fold ventrally at the artlculation of the carpus and propodus in the major chela.

This species is named for Mr. W11l1am W. Anderson who collected many specimens wh1le in charge of the "Pellean".

\section{Pylopagurus bartlett1 (A. M1Ine Edwards)}

Eupagurus bartlett1 A. M1Ine Edwards, 1880, p. 41.

Pylonagurus bartlett1 Milne Edwards and Bouvier, 1893, p. 91, pl. 7, 11gs. 1-9. --Springer and Bull1s, 1956, p. 16. --Gordan, 1956, p. 340.

MATERIAL EXAMINED: E1ght specimens from five stations. 
Male type; St. Vincent, 146 fms., "Blake" sta. 223.

Qule of Nexico: $27^{\circ} 081 \mathrm{N.,} 84^{\circ} 53^{\prime} \mathrm{W}_{0.3} 150-175 \mathrm{fms.3}$ April 3, 1954, "Oregon" sta. 954, 1 male, USMM 97467. $25^{\circ}$

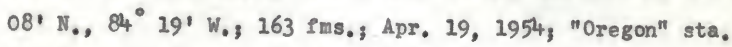
1026, I remale, USMM 97468 .

ofe mouth of Orinoce River: $09^{\circ} 45^{\prime} \mathrm{N} ., 59^{\circ} 45^{\prime} \mathrm{W}, \mathrm{s}$ Nov, 4, 1957, "Oregon" sta. 1989, 2 males, 2 females (1 ovig.). off mouth of Amazon River: $02^{\circ} 04^{\prime} \mathrm{N} ., 47^{\circ} 00^{\prime} \mathrm{W}_{0}, 125$ fms.; Nov. 17, 1957; "Oregon" sta. 2080, 1 male, USMM 101663. RAMGE: Western Gulf of Mexico to mouth of Amazon River, 82 to 209 frms.

DIAGNOSIS: Exposed Paces of chelae bear hat-shaped projections which overlap and Interlock; each project1on has a many-toothed, uneven margin and a strong, rounded tooth above. Outer half of minor chela contributes to operculum. One of larger species in genus.

DESCRIPTION: Shleld rounded, as broad as long. Frontal margin narrow, ralsed. Rostrum obtuse, equaling lateral teeth. Cardlae plate narrow, lightly calclfled. Eyes short, greatly swollen at cornea; four tufts of thin setae on dorsal surface. Eye scale triangular, margins ralsed, apical spinule present. Antennular peduncle exceeding eye by terminal segment. Antennal peduncle exceeding eye by two-thirds of terminal segment; second segment with a denticle on inner angle, small spinules on short outer projection. Ac1ele easily exceedIng eye. 
Chelipeds with plentiful setae, a few marginal spinules on dorsal surfaces of carpus. Marginal projections of chelae strong, broad, usually with two stout spines, or one flanked by denticles. A broad, median longltudinal ridge extends full length of major manus; Planked by a shallow depression on e1ther s1de. Dactyl presents a sharper dorsal ridge consisting of a row of projections. Minor chela similar to major; inner margin unarmed, setose. Dactyl smooth, save for a dorsal and a marginal row of setae.

Walking legs compressed; dorsal margins wavy, setose, unarmed. Dactyl with a line of corneous spinules on ventral margins. Propodus of fourth perelopods with a rasp about I1ve scales w1de; rasp of flfth covers most of outer, distal half of propodus. Thumb-shaped sternal projection f111s space between third coxae. Males bear numerous swollen hairs, chitinous in appearance, between third, fourth, and sifth pairs of coxae. These halrs smaller and much less numerous on females. Female gonopods feeble, with a distal brush of long, PIne ha1rs. Eggs large, about $1 \mathrm{~mm}$. In diameter. Telson nearly symmetrical, feebly arned on inner margins of dorsal lobes.

COLOR: Specimons Irom "Oregon" sta. 1989 after one year in alcohol. Mushroom-11ke projections on chelae apricot with spines on marginal projections coral. Walking legs Indian orange, with broad bands and blotches of white obscuring much of the orange color. 


\section{8 .}

MEASUREMENTS (mm.): Shield, length 7.0, width 7.0 ; carapace 11.7; eyes 5.3 , major chela, length 14.5 , width 9.0 , dactyl 7.0, minor chela, length 10.8 , w1dth 4.0 , dacty 16.0 , third perelopod, basis-1schium 5.3, merus 7.2 , carpus 5.8, propodus 5.6, dacty 19.4 .

\section{Prlonagurus cavimanus Chace}

Pylonagurus cavimanus Chace, 1939, p. 48. MATERIAL EXANINED: Two specimens from Cuba.

Cubs: Holotype female, MCZ 10233; $22^{\circ} 07^{\prime} \mathrm{N} ., 81^{\circ} 08^{\prime}$ W. 150-170 fms.; Feb. 25, 1939; "Atlant1s" sta. 2963-B. $23^{\circ} 09^{\prime} \mathrm{N}_{.}, 81^{\circ} 26^{\prime}$ W.; 230 Ims.; May 9, 1939; "Atlant1s" sta. 3463 ; 1 female.

RANGE: North and south of Cuba, 170 to $230 \mathrm{fms}$.

DIAGNOSIS: Face of major chela unusually concave except for slight central rise. Spinulose margins raised and almost perpendicular to plane of face. Surface covered by Plat, mushroom-like tubercles.

DESCRIPIION: Shield glabrous, very convex laterally. Rostrum obtuse, exceeding lateral teeth but not ophthalmic somite. Cardiac plate short, narrowed anteriorly. Eyes strong, more swollen at cornea than basally; length not ex ceeding that of shleld. Eye scales narrow, subapical spine unusually strong. Antennular peduncle equaling eyes; that of antenna not reaching cornea. Aclele styliform, setose on 


\section{9.}

Inner margin. Flagelium very thin, exceeding perelopods, nude except for several long halrs.

Major cheliped with several spinules on outer ventral angle of merus; carpus armed with dorsolateral rows of spines and an irregular dorsal row medial to shallow, m1d-dorsal trough. Face of chela narrow proximally, with two posteriorIy directed spines at this point. Distally from here the margin turns up unt11 1t again Plattens out at the 11ngert1ps. Surface tubercles rounded and flat from above; not continuous with spinous margins. Cutting edges of fingers composed of Irregular, ealcareous teeth. Corneous t1ps minute. Carpus of minor cheliped with several strong spines on dorsal surface of carpus. Chels with inner margin setose, outer armed with numerous spines of varying size. Straight cutting edges corneous on dactyl, with Pine calcareous teeth on pollex.

Walking legs compressed, sparsely setose. Dactyls with stiff setae dorsally, short corneous setae ventrally. Propodus of fourth perelopods with rasp three scales wide; dactyl with comb-like, single row of scales. Propodus of fifth with rasp on distal two-thirds of outer surface. Sternum separating third maxillipeds has two median, minute spinules; that between fourth perelopods bears a single seta, while last sternal plate presents two such ha1rs. Female gonopods approximated. Terminal abdominal appendages subsymmetrical. Telson unarmed.

MEASUREMENTS (mm.): Female from "Atlant1s" sta. 3463. 
Shleld, length 7.8, width 5.5; carapace 11.4 ; eyes 6.3 ; right chela, length 13.4 , w1ath 7.2 , dactyl 6.0 , left chela, length 8.0 , width 2.5 , dacty 4.0 .

\section{Pylooasurus chace1 n. sp.}

MATERIAL EXAMINED: Holotype male and paratype male; $07^{\circ} 25^{\prime} \mathrm{N}_{.}, 54^{\circ} 35^{\prime} \mathrm{W}_{.}, 75-80$ rms., Sept. 8, 1958, "Oregon" sta. 2289.

RANGE: Type local1ty, off Surinam.

DIAGNOSIS: Major cheliped large, evenly Ilexed; tubereles on face of chela with four to eight sides, each with a short denticle directed forward. A large tooth on dorsal surface proximal to inner hinge joint.

DESCRIPTION: Shield smooth, three anterlor projections equal. Eyes short, swollen distally; two tufts of bristles on dorsal surface of stalk. Retracted antennular peduncle reaches cornea. Antennal peduncle exceeding eyes, acicle equaling. Plagellum equaling perelopods; a few flne setae present.

Major chellped heavy. Carpus covered with short, stiff setae above; outer dorsal margin feeble, inner armed with ten teeth. Surface of major chela covered with even, elose-fitting tubercles, each with four to elght sides and a distally-directed dorsal pap1lla. Outer margin evident on pollex as well as palm, Inner margin of palm consisting of a few evenly spaced 
denticles. Tooth proximal to inner hinge foint much larger. Dactyl has a large denticle at beginning of marginal row of minute denticles. Cutting edges of fingers consist entirely of calcareous, crushing teeth.

Minor chela granular on dorsal angle and outer surface. Dactyl smooth, longer than usual. Cutting edges typical. Carpus of minor cheliped with a lew spinules on dorsal angle. Walking legs quite smooth and almost nude. A minute distodorsal spinule on each merus; short, sparse setae on dorsal angles of all segments; spinulose setae on dactyls.

Propodal rasp uniseriate on fourth perelopods; rasp of fifth covering a little wore than outer half of chela. Sternum separating third maxillipeds with a median tuft of fine setae but lacking spinules. Swollen hairs occur on rounded projection between third coxae, on long plate separting fourth coxae and at outer ends of plates between fifth coxae. All three pleopods blramous. Telson slightly asymmetric, minutely toothed on margins of median, distal notch. COLOR: Bodies and head appendages blackened. (Specimens in formalin four months.) Chelipeds with peach red to orange vermillion blotches on a background of cream to salmon. Coloring of walking legs generally darker, in broad broken bands.

MEASUREMENTS (mm.): Shleld, length 4.1, width 4.3; carapace 6.8 , eyes 3.8 , right chela, length 8.5 , width 5.0 , dactyl 4.3 ; left chela, length 6.0 , width 2.3 , dactyl 4.1 ; 
third right pere1opod, basis-1sch1um 3.0, merus 4.7 , carpus 3.9 , propodus 5.0 , dacty 7.9 .

\section{Prlonagurus corallinus (Benedict)}

Eunagurus corallinus Bened1ct, 1892, p. 23.

Pylonagurus ungulatus M1lne Edwards and Bouv1er, 1893, p. 90, pl. 6, 11g. 15-18. Not Pylonasurus ungulatus studer, 1883, p. 26, pl. 2, 11g. 13 a -c.

Pagurus corellinus Hay and Shore, 1918, p. 412, p1. 30 , 11g. 4. --Gordan, 1956, p. 328.

Pylonagurus coral11nus springer and Bull1s, 1956, p. 16. MATERIAL EXAMINED; Nineteen specirens from 12 stations. Qef South Carolina: $32^{\circ} 34^{\prime} \mathrm{N} ., 79^{\circ} 05^{\prime} \mathrm{W}, 319 \mathrm{fms.3}$ May 9, 1940; "Pel1can" sta. 194-10, 4 males, 1 ov1g. female. off Geore1a: "Umbrella Creek, Ga., W. W. Anderson,". I male, 2 remales.

off eastern Flor1da: $30^{\circ} 28^{\prime} \mathrm{N} ., 80^{\circ} 48^{\prime} \mathrm{W} . ; 15 \mathrm{fms} . ;$ Jan. 25, 1940, "Pel1can" sta. 176-7, 1 male. $28^{\circ} 09^{\prime} \mathrm{N}$. , $80^{\circ} 12^{\prime} W_{.} ; 18 \mathrm{fms,3}$ Jan. 17, 1940, "Pellcan" sta. 168-3, 1 in a bryozoan colony.

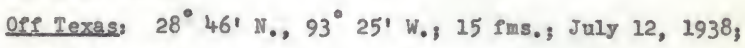
"Pelican" sta. 100-3; 1 in bryozoan.

of Western Florida: $30^{\circ} 13^{\prime} \mathrm{N} ., 86^{\circ} 10^{\prime} \mathrm{W}, 15 \mathrm{fms}, \mathrm{s}$ Mar. 9, 1939; "Pel1can" sta. 151-2, 2 ovig. females. off Cape San Blas; $29^{\circ} 28^{\prime}$ N., $85^{\circ}$ 31' W. 12 fms.; Feb. 1, 1956, "A. A. Jakkula"; 1 male, 1 ov1g. remale. 


\section{3.}

$28^{\circ}$ 09' N., $80^{\circ} 12^{\prime} \mathrm{W}_{0} ; 18 \mathrm{fms}$; Jan 17, 1940, "Oregon" sta. 730,1 male in bryozoan. "West Florlda", 19 fms., "Bache," Wm. St1mpson, 1 female (MCZ specimen labeled Pylonagurus ungulatus by A. Milne Edwards).

South Florida: Tortugas; 25 fms.; 1924, W. L. Schmitt, 1 male. $25^{\circ} 04{ }^{\prime} N_{0}, 82^{\circ} 591^{\prime} W_{0} ; 26$ fms.; Mar. 19, 1885; "Albatross" sta. 2414; 1 in bryozoan. Off Key West, 60 Ims.,

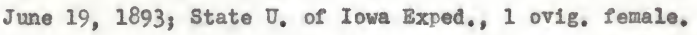

The USNM has 60 other specimens, malnly Irom "Albatross" stations, taken along the Gulf coast, at depths up to 56 Ims., from the delta of the Mississippl to the stralts of Florida and off Cabo Catoche, Yucatan.

RANGE: Beaufort, N.C., to the northern and eastern Gulf of Mexico south to Campeche Bank, 15 to 60 Pms.

DIAGNOSIS: Major chela resembling that of $P$. discoidalis in general shape. Surface covered with tubercles, each of which bears a spinule. Spinules directed upward on proximal part of chela, forward on d1stal part. Margin of strong, upward-pointing spines surrounds entire face of chela. Strong spine projects from sternum between coxae of th1rd pereiopods. DESCRIPTION: Shleld smooth, rounded laterally. Blunt, triangular rostrum exceeding lateral teeth. Byes shorter than shleld, swollen at cornea. Eye scale triangular distally, w1th strong subapical spinule. Antennular peduncle exceedIng eyes by terminal segment. Antennal peduncle exceeding eyes by two-thirds of terminal segment; second segment with 


\section{4.}

a spinule at inner angle and at tip of short outer project1on. Aclele slender, subequal to cornea.

Major cheliped with snall, spinous projections on dorsal surfaces of both carpus and propodus. Carpus with spinous denticles on outer distal and inner marglns. Chela oval proximally, more pointed distally, fringed with close-set spines. Face covered with small, spinous projections; row with stronger spines extends from proximal margin to base of cutting edges. Minor chela small, face rather flat and granular; margins beaded. Fingers spooned; cutting edges corneous, with a slight proximal gape.

Walking legs compressed, with a few distal spinules on dorsal angles of carpus. Propodus and dactyl bear sparse, short setae; those on dactyls directed more or less inward and forward. Rasp on propodus of fourth perelopods small, placed distally; dactyl short, stout. Propodus of elfth with rasp on distal outer half including surface of weak dactyl. Narrow spine projects from sternum closely spaced third coxae. Ovigerous female from off Cape San Blas (carapace length $4 \mathrm{~mm}$ ) ) carries over $600 \mathrm{eggs}$, each $0.4 \mathrm{~mm}$. in dianeter.

COLOR: Specimens from "Oregon" sta. 730 after seven years in alcohol. Scarlet blotches and vermiculations appear on merus of major cheliped and in two broad bands on carpus. Proximal part of face of chela suffused with rose; IInely spinulose border scarlet. Walking legs with scarlet 
on most of merus, in two bands on carpus, one broad band on propodus and a narrow band on dactyl.

MEASURENENTS (m..): Specimen from "Oregon" sta. 730. Shield, length 4.5, width 4.2 ; carapace 8.5 ; ejes 3.5 ; right chela, length 10.7 , width 6.0 , dactyl 6.5 ; left chela, length 7.0 , width 3.0 , dacty1 4.6, third right perelopod, basis-1schium 3.5, merus 5.6 , carpus 4.3 , propodus 6.5 , dactyl 8.0 .

REMARKS: $P$. corallinus 18 closely related to $P$. cervicornis and P. vartans of the Gulf of Callfornia and to . Eulanensis Irom northeastern South America. It differs from cerplcornis in having the tubercles on the face of the hand more even in size and greater in number. P. varians has the spinulose tips of the tubercles directed forward Instead of at right angles to the face.

More striking differences occur in the structure of the sternal spine projecting from between the third pair of coxae. In corallinus the spine is narrow and sharp and the coxae are very closely spaced. R. cervicornis and $\mathrm{P}$. gulanensis have the coxae more widely separated and the spine heavier, more blunt and setose at the t1p. P. varians also has the coxae more widely set and a spine with numerous denticles around the tip as in a mace.

All of these specles usually live in bryozoan colonies. 


\section{6.}

Prlonagurus discoldel1s (A. Milne Edwards)

Eunagurus discoldalis A. M1lne Edwards, 1880, p. 41. Prlopagurus discoldalis Milne Edwards and Bouvler, 1893, p. 76, p1. 6, 11gs. 7-14. --Gordan, 1956, p. 340. MATERIAL BXAMINED, Thirty-five specimens from five areas.

Holotype males Montserrat; 120 fms., "Blake" sta. 157, specimen $42 \mathrm{~mm}$. 1ong, in a scaphopod $65 \mathrm{~mm}$. long. South Carolina: $32^{\circ} 47 \mathrm{r}$., $78^{\circ} 15^{\prime}$ W.; 90 fms. 3 Feb. 14, 1940; "Pellcan" sta. 183-3; 1 fomale.

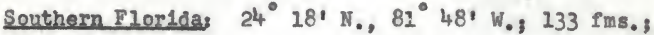
Feb. 19, 1902, "F1sh Hawk" sta. 7286, 1 female, 1 in an anemone. $24^{\circ} 17^{\prime} \mathrm{N}_{0}, 81^{\circ} 58^{\mathrm{l}}$ W.; $132 \mathrm{fms}$, ; Feb. 14, 1902, "Fish Hawk" sta. 7280, 3 males, 2 in scaphopods, 1 in a U-shaped, calcareous tube. $24^{\circ} 21^{\prime} \mathrm{N} ., 81^{\circ} 52^{\prime} \mathrm{W}_{0}, 109 \mathrm{fms}, 3$ Feb. 19, 1902; "Fish Hawk" sta. 7282, 1 male, 3 in scaphopod shells. Off Fowey Rocks and MLami; 30-100 fms.; 1916; J. B. Henderson; 3 males. Off Key West and Sambo Key; 61-135 fms. J. B. Henderson; 2 males, 4 females (2 ovig.), 3 in scaphopods surrounded by single anemones. eff mouth of Orinoco River: $09^{\circ} 45^{\prime} \mathrm{N} ., 59^{\circ} 45^{\prime} \mathrm{W} .3$ 200 fms.; Nov. 4, 1957, "Oregon" sta. 1989, 1 male. off mouth of Amazon Rivex: $02^{\circ} 35^{\prime} \mathrm{N} ., 47^{\circ} 48 \mathrm{~W}$.; 120 Pms.; Nov, 15, 1957, 4 males, 7 Pemales (1 ovig.); 1 juv. RANGE: South Carolina to wouth of Amazon R1ver (not yet taken in Gulf of Mexico), 30 to 508 Pms. (Milne Edwards 


\section{7.}

and Bouvier, 1893).

DIAGNOSIS, Major chellped massive, short; face of chela rounded to form an operculum in a scaphopod shell. Body and appendages in shape of long, straight cone.

DESCRIPTION: Carapace smooth, evenly rounded; shield longer than cardiac plate. Rostrum triangular, exceeding ophthalmic ring. Lateral teoth blunt, scarcely exceeding Prontal margin. Eyes heavy, short, l1ttle swollen at cornea. Eye scales long, triangular; edges raised; subapical spinule prominent. Terminal segment of retracted antennular peduncle almost reaches cornea. Second segment of antennal peduncle armed with a minute spinule on inner angle, an outer projection forming a strong spine. Terminal segment extending to midpoint of cornea. Acicle lightly setose, slightly exceeding cornea.

Major chellped short, propodus subequal to rest of leg. Carpus truncate, with transverse, granular ridges dorsally, a denticle immediately behind inner hinge. Proximal part of propodal surface less than a fourth as long as opercular surface. Opercular margin of fine denticles directed perpendicular to surface on proximal half, In same plane on distal half. Operaular surfase makes an angle of about 120 degrees with rest of chel1ped. Dactyl broad, elosing without a gape and contributing perfectly to operculum. Teeth calcareous, very blunt; corneous tip on dactyl. Minor cheliped small, only carpus visible from above. 


\section{8.}

Carpus armed with uneven spines on dorsal angle and distodorsal margin. Chela about twice as long as wide gape absent; many tufts of Pine setae ventrally and laterally on pollex, distoventrally on dactyl.

Walking legs equal to major cheliped. Carpus with two dorsal rows of denticles, the inner row terminating in a short spinule. Dactyl short, compressed; claw sharp, yellow corneous, a third as long as rest of dactyl; splnulose setae on distal ventral and dorsal margins. Propodus of fourth perelopods short, with a row of strong scales on ventral margin. Propodus of I1fth palr with rasp on distal fourPlfths of ventral surface and distal half of outer surface.

Sternum between third palr of coxae supports a short, rounded projection. W1de sternum between fourth pair bears abundant setae and several pecullar swollen ha1rs. Sternum between fifth pair about half as wide, rounded distally and with the same swollen ha1rs. Females lack these odd hairs. Paired pleopods of female small, approximated. Egg mass numbers about 200, each egg $0.5 \mathrm{~mm}$. In diameter. Posterior abdominal appendages subsymmetrlcal; terminal lobes of telson each ending in a strong spine, with several smaller splnes on inner margins.

COLOR: Striking pattern of red and 1ighter hues appears on anterlor appendages. Eyestalks with a narrow red band at level of tips of eye scales, with apricot on remalning surface to cornea. Major cheliped with fine, bright red, 
dorsal margins distally on merus and carpus, proximally on propodus and on ralsed proximal edge of opercular surface. Remaining color varies from salmon to apricot, except for three large, white patches forming a triangle around center of opercular surface and white onds of fingers. Minor chela with a red band proximally and a red patch next to base of dactyl. Walking legs with red bands of varying width and Intensity at several points.

MEASUREMENTS (m.): Total length 40, shleld, length 5.8 , w1dth 5.0 , carapace 9.6 , eyes 2.9, major chela, length 9.4, width 7.4 , dacty 5.6 ; minor chela, length 4.5 , width 2.2, dacty 2.8 , third leg, bas1s-1schium 2.5, merus 4.6 , carpus 4.8 , propodus 3.5 , dacty 15.8 .

REMARKS: Only male specimens bear the swollen halrs on the fourth and fifth sterna. A male from "Oregon" sta. 2084 has three rh1zocephalans attached and also lacks the unusual appendages.

\section{Pylopequrus eresus (A. M1Ine Edwards)}

Eubsgurus erosus A. Mine Edwards, 1880 , p. 42. Prlopseurus erosus Milne Edwards and Bouvier, 1893, D. 89, p1. 6, 11gs. 27-30, Gordan, 1956, p. 340 .

MATERIAL EXAMINED; Three specimens from Barbados.

Barbades: Holotype ovig. Temale, MCZ 4089; 73 fms.; "Blake" sta. 290. $103 \mathrm{fms.;} \mathrm{"Blake"} \mathrm{sta.} \mathrm{273;} 1$ male. 84 


\section{0.}

Ims.3 "Blake" sta. 296; 1 female.

RANGE: Barbados and St. Vincent; 73 to $210 \mathrm{fms.}$

DIAGNOSIS: Stalked tubercles of major chela and margin of minor chela unusually large, widely spaced, and irregularIy sculptured.

DESCRIPTION: Shleld glabrous, as broad as long. Cardiac plate very short. Eyes with cornea moderately swollen. Eye scales trlangular, each with minute subapical spines. Antennular peduncle equals eyes. Antennal peduncle reaching cornea, acicles small, with a minute terminal spinule. Flagellum fine, with a few long halrs.

Major chela with unusually large tubercles, generally well separated, and each w1th a different, but similar shape. Outer margins of fingers armed with a few rounded teeth whlch project from outer parts of large tubercles. Sparse setae encircles chela along margins. Dactyl with two rows of wide, sculptured tubercles. Cutting edges of fingers present uneven calcareous teeth.

Carpus of minor cheliped armed with six dorsal spines. Chela presents ten strong spines with minute, corneous tips on outer margin. At least 20 bulb-like tubercles appear between this margin and a line running back from apex of cutting edges.

Walking legs short; dactyls with stiff setae rising from serrate dorsal edge, five corneous spinules on ventral angle. Claws curved and sharp. Propodus of fourth pere1- 


\section{1.}

opods with long-scaled rasp distally. Dactyl short, with a row of fine scales. Chela of flfth perelopods with a rasp on distal three-fifths of outer surface.

Sternum separating third max1llipeds has a spinule on each slde of median Indentation. Coxae of third legs approximated, with only a narrow, short projection between them. Posterior abdominal appendages subsymmetrical, telson unarmed. Abdomen short, uropods reaching fifth pereiopods. MEASURENEITS $\left(\mathrm{mm}_{0}\right)$ : Shleld, length 3.5 , width 3.5 ; carapace 4.9; eyes 3.3 ; right chela, length 6.0 , width 4.4 , dactyl 3.1; third right perelopod, basis-1schium 1.3, merus 3.0 , carpus 2.7 , propodus 2.6 , dactyl 3.5 .

\section{Prlonagurus g1bbosimanus (A. Milne Edwards)}

Bupagurus glbbosimanus A. Milne Edwards, 1880, p. 42. Pylonegurus glbbosimanus Milne Edwards and Bouvier, 1893, p. 99, p1. 7, 11gs. 18-20. -Gordan, 1956, p. 340. MATERIAL EXAMINED: Three specimens from two stations. Ov1gerous female type; Martinique; 170 fms. "Blake" sta. 906.

Oef mouth of Amazon River: $02^{\circ} 35^{\prime} \mathrm{N} ., 47^{\circ} 48^{\prime} \mathrm{W} .3120$ fms.; Nov. 15, 1957; "Oregon" sta. 2068; 2 males. RANGE: M1lligan Key to mouth of Amazon River, 120 to 270 fms.

DIAGNOSIs: Right chela massive, with unusually high 


\section{2.}

ridges; surface projections meshing perfectly, slightly rounded above. A small species.

DESCRIPTION: Shleld glabrous, broader than long. Rostrum obtuse, equaling lateral teeth. Eyes shorter than shleld, moderately swollen at cornea. Eye scales triangular, short; margins raised, subapical spine strong. Antennular peduncle exceeding eye by half of terminal segment. Antennal peduncle barely exceeding eye; acicle feeble, reachIng cornea. Flagellum scarcely equaling perelopods; several long setae and numerous minute setae present.

Kajor cheliped strong; carpus with a few short spines or denticles on Inner dorsal margin. Chela heavy, uniquely ornamented, margin present only on inside. High, uneven ridges extend from proximal margin of hand to tips of pollex and dactyl. Perfectly meshing profections cover dorsal surface of chela. Minor cheliped with two rounded spines distodorsally. Chela with projections covering outer threefourths of surface.

Walking legs short, sparsely setose above and below; lightly armed with corneous spinules on distoventral angle of propodus and ventral angle of dactyl. Propodal rasp of fourth perelopods four scales wide; rasp of fifth covering distal three-fifths of outer surface. Sternal projection between third coxae longer than broad, with two unusually swollen ha1rs at tip; sterna between fourth and fifth coxae also bear these hairs. 
Abdomen short; posterior half covered with fine, short setae. Male pleopods completely uniramous, Bases of uropods each armed with a strong denticle on outer distal margin. Telson short, asymetric, unarmed.

Colon: (Specimen from "Oregon" sta. 2068 after one year in alcohol). Shield with a coral spot near posterior end of each lateral groove. Byestalks burnt slenna distally fading to cream at bases. Dorsal surface of carpus of chelipeds with salmon vermiculations, Chelae light apricot w1th darker color showing at junctions of projections. Broad transverse bands on all perelopods range from coral to salmon.

MEASUREMENTS (mm.): Shield, length 2.5, width 2.6; carapace 4.1; eyes 2.2; major chela, length 4.8, w1dth 3.3 , dactyl 2.7, minor chela, length 3.1, width 1.5, dactyl 1.6 , third perelopod, basis-1schivm 1.5, merus 3.1 , carpus 2.1 , propodus 2.4 , dactyl 3.0 .

\section{Prlonagurus hendersonl $n$, sp.}

MATIRIAL EXAYINED; Holotype female (ovig.); southeast of Sand Key Light, Fla.; 61 Ims.; J. B. Henderson. Paratype female (apparently a cast), off Texas; W. G. Hewatt.

RANGE; Florida Straits and off Texas.

DIAGNOSIS: Small species, near P. serratus. Najor chela differs in presence of fewer and stronger teeth in 
margin, strong teeth or blunt spines in proximal end of median dorsal ridge of palm, much stronger ridge on dactyl. DESCRIPIION: Eyes equaling shleld. Antennal acleles flne, scarcely reaching cornea. Flagellum slender, subequal to perelopods.

Major cheliped appears midway between those of $P$. glbbosimanus and $D$. serratus. Carpus with flve spines or denticles on inner dorsal angle. Lateral margins of chela composed of quite even, strong teeth, flattened at their extremities. A few strong teeth in proximal border includIng three at beginning of median ridge. Longltudinal ridge of dactyl strong, w1th two rows of meshing plates.

Minor cheliped with five spines on outer dorsal ridge of carpus. Chela with two proximal spines and an outer margin of strong teeth. Perelopods as in serratus and bartlett1; fourth with four rows of scales in propodal rasp. Female holotype carries about $70 \mathrm{eggs}$, each $.5 \mathrm{~mm}$. In diameter.

MEASUREMENTS (m.): Holotype. Shleld, length 2.4, width 2.5 , carapace 3.5 ; eyes 2.4 , major chela, length 4.5 , width 3.0 , dactyl 2.0, minor chela, length 2.9 , width 1.3 , dactyl 1.5 .

Prlonagurus guianensts n. sp.

MATERIAL EXAMINED: Holotype male, 3 paratypes (1 male, 
2 In bryozoan dweIlings), $05^{\circ} 571 \mathrm{~N} ., 52^{\circ} 20$ ' W., 28-31 fms.; Sept. 11, 1958; "Oregon" sta. 2307.

RANGE; Known only from types.

DIAGIOSIS: Differs from $\underline{p}$. corallinus in having face of major chela more produced, depressions inside of margins much smaller; denticles of face fewer in number and less spinous. Separation of third pair of coxae is an even more noticeable difference. Intercoxal projection rounded at t1p and supporting a few setae rather than being spinous. Color and measurements similar to those of corallinus.

\section{Pylopagurus hispidus (Benedict) n, comb.}

Eunagurus hisoidus Bened1ct, 1892, p. 26.

Pagurus hispidus Gordan, 1956, p. 330.

MATERIAL EXAMINED: Male holotype, USNM 7759; off Havana, Cuba; $23^{\circ} 10^{\prime} \mathrm{N} ., 82^{\circ} 20^{\prime} \mathrm{W}_{0}, 133 \mathrm{fms}$.; Apr. 30 , 1884, "Albatross" sta. 2163; coral bottom.

RANGE: Known only from the type.

DIAGNOSIS: Major chela bizarrely sculptured, with a prominent boss on dorsal surface.

DESCRIPTION: Carapace smooth, shleld evenly rounded, with shallow longltudinal grooves behind lateral teeth. Rostrum very broad; exceeding lateral teeth. Cardiac plate 11ghtly calc1fled.

Eyes about three-fourths as long as shield, cornea swollen; eye seales of typical pagurus shape, w1th subapical 


\section{$226^{\circ}$}

spinule, Unextended antennular peduncle reaches cornea; flagellum bears very fine setae on underside. Antennal peduncle long, exceeding eyes by terminal segment; flagellum slender, with a few fine setae.

Major chela large; face unusually sculptured; a high, rounded boss rises perpendicularly from surface behind gape, two deep depressions 110 posterior to boss; lateral depressIon more shallow, connected with edges by six clefts in ra1sed marg1n. Ridges on fingers plank cutting edges; entire surface of hand covered with irregular tubercles, long bases of which may be seen from sldes. Cutting edges of both fingers with a few irregular, calcareous teeth.

Minor chela w1th large tubercles along outer edge, becoming progressively shorter toward inside, ending in two rows of small, corneous-tipped tubercles. Large tubercles on outer margin each bear a calcareous, thumb-shaped projectIon with a minute, corneous cap. Cutting edges of fingers eveniy serrate, composed of a few minute, calcareous teeth Interspersed with corneous scales. Sculpturing on dactyl consists only of low, corneous-tipped tubercles which occur mainly in a row along outer edge. Sparse setae appear on margins and beneath fingers.

Second perelopods with setae rising from five indentatlons on dorsal surface of merus, and heavier, corneous setae from four similar points on ventral side. Dactyl with corneous setae at elght points on dorsal margin and five long, 
corneous scales along ventral margin. Corresponding areas of thlrd perelopods bear fine setre; only two corneous scales distally on ventral margin of dactyl.

Approximated bases of third perelopods leave no room for a median sternal projection; however, swollen halrs appear Inside coxae of third pair and on sternum separating fourth coxae. Coxal openings of fifth pair each marked by a protuberance bearing a tuft of setae distally. Telson symmetrical, with the calcifled distal lobes unarmed.

MEASURAMENTS ( $\left.\operatorname{mm})_{*}\right):$ Shleld, length 3.2, w1dth 3.2; carapace 4.5 , eyes 2.5 , major chela, length 5.0 , width 3.8 , thickness, to ra1sed margin 1.8 , to top of boss 3.0 , minor chela, length 4.0 , width 2.0 .

\section{Pylonagurus rosacevs Milne Edwards and Bouvler}

Prlonagurus rosaceus M11ne Edwards and Bouvier, 1893, p. 97, p1. 7, 11g. 10-17. --Gordan, 1956, p. 340.

MATERIAL EXAMIRED: Twenty-two spec1rens from four stations.

Holotype female: Grenada; 92 Pms.; "Blake" sta. 253, 1 female.

Worth Carolinas $33 \mathrm{ml}$. south of Cape Lookout lightsh1p; July 8, 1915; "F1sh Hawk"; 1 male.

Elorida: Key West, off Western Dry Rocks; 65 Pms. 3 J. B. Henderson; 1 male. 


\section{8.}

Surinam: $07^{\circ} 25^{\prime}$ N., $54^{\circ} 351$ W.3 75-80 fms., Sept. 8, 1958, "Oregon" sta. 2289; 15 males, 4 Pemales (3 ovis.).

RANGE; North Carolina to Surinam; 80-92 Ims.

DIAGNOSIS, Face of major chela rounded; tubercles with scalloped margins, dorsal surface ra1sed to form a strong dorsal tooth. Walking legs striped.

DESCRIPTION: Shield glabrous, evenly convex, rostrum scarcely exceeding lateral teeth, Planked by two or three strong setae on each s1de. Eyes strong, subequal to shleld. Eye scales typlcal, well separated. Retracted antennular peduncle reaches base of cornea. Antennal peduncle reaches cornea when extended. Acleles subequal to eyes. Flagellum equaling perelopods, shorter than major cheliped; one or more long setae at 1rregular 1ntervals.

Major cheliped long, massive. Dorsal surface of carpus with scattered short spinules and numerous long setae; Inner margin with s1x spines. Face of chela covered with usual mushroom-11ke tubercles, each with a scalloped edge and a strong dorsal tooth. Surface of palm evenly convex, of pollex Plat; dactyl with a strong ridge. Margin cons1sts of strong, blunt teeth. Fine setae rise from base of each tubercular tooth. Strong setae forin a fringe below margins. M1nor cheliped reaching dactyl of major. Carpus with elght spines on dorsal angle. Chela typical, with tubercles small and margin of strong teeth only on outer edge. Walking legs with a minute distodorsal spinule on merus of each. 
Dactyls with usual corneous setae above and below; claws strong.

Fourth pereiopods with uniserlate rasp; propodus of fifth with rasp on distal two-thirds. Sternal plate separating third maxillipeds lacks spinules. Males present numerous swollen hairs on rounded projection between third pair of coxae, on sternal plate between fourth pa1r, and at ends of plate separating last pair. Females lack these ha1rs. Male pleopods present short outer ramus. Distal lobes of telson asymetrie; each armed with four sharp spines.

COLOR: Specimens from Surinam after four months in formalin. Thorax and abdomen dark, apparently because of chemical action. Shield symmetrically marked with spots of Indian red. Antennular peduncle violet. Eye stalks pale above, red below. Chelipeds apricot on faces of chelae to orange vermillion on merus and carpus. Walking legs with three burnt orange stripes on outer sides, one stripe on dactyl; claws dark amber.

MEASUREMENTS (mm.): Male from Surinam. Shleld, length 4.7, w1dth 4.8 ; carapace 8.2 ; eyes 4.6 ; right chela, length 10.0 , width 5.5 , dactyl 5.0 ; left chela, length 6.6 , width 2.6, dactyl 3.9, third right pereiopod, basis-ischium 4.3, merus 5.8 , carpus 4.6 , propodus 5.8 , dactyl 9.0 . 


\section{Prlopagurus serratus n. sp.}

MATERIAL EXANINED: Holotype female; off Honduras; $15^{\circ} 15^{\prime} \mathrm{N},, 81^{\circ} 19^{\prime} \mathrm{W}_{*}, 145 \mathrm{fms} . ;$ Aug. 25, 1957; "Oregon" sta. 1894.

RANGE; Known only from type.

DIAGNOSIS: Similar to P. bartlett1. D1ffers as follows: Major chela with interlocking tubercles only slightly rounded on faces, not dent1culate. Margin composed of even dent1cles on outer edge; inner edge less even but not formIng spines. Dactyls longer and more slender. Antennae eas1ly surpassing perelopods.

DESCRIPTION: Carapace smooth, nearly nude. Rostrum and lateral teeth equal. Eyes short, much swollen at cornea; scales widely spaced, typleal of genus. Antennular peduncle exceeding eyes by two-thirds of terminal segment. Antennal peduncle a little shorter. Second segment with a minute denticle at inner angle and tip of outer projection.

Carpus of major chellped with six short spines on Inner dorsal margin. Chela with two similar spines at base of inner margin, remainder of margin composed of strong, mostIy b1f1d, denticles. Tubercles small, finely toothed margins Interlocking completely. Proximal border of face of chela has only two dent1cles projecting above tubercles. Outer margins of both chelae serrate, composed of small denticles polnting forward and little elevated. Carpus of minor 
cheliped with a distodorsal row of about pive denticles. Walking legs slender, dactyls especlally so. Setae on dorsal angles stiff, sparse. Dactyls not twisted; claws fine, sharp. Rasp of fourth perelopods has about six scales in each dlagonal row. Rasp of fifth covering distal half of propodus; a narrow double row on dactyl.

Thumb-like plate between coxae of third perelopods supports four swollen halrs, the median two much larger. Female gonopods quite strong and closely spaced. Bggs number about 100, each $1.0 \mathrm{~mm}$. In diameter. Telson subsymmetrical, 11ghtly toothed on median notch.

COLOR: After one year in alcohol, specimen shows color only in a red dot at base of cutting edge on dactyl of minor chela,

MEASUREMENTS ( $\left.\mathrm{mm}_{\bullet}\right):$ Shleld, length 4.4 , width 4.5 ; carapace 6.5 , eyes 3.0 , major chela, length 8.0 , width 5.5 , dactyl 3.8 , minor chela, length 6.6 , wiath 2.5 , dactyl 3.5 ; third right perelopod, basis-1schium 3.1, merus 5.2, carpus 3.8 , propodus 4.2 , dactyl 7.0 .

\section{Genus Solropagurus St1mpson}

Shield well calcified, glabrous, sparsely setose and much longer than cardiac plate. Eyes short, stout; cornea greatly dilated. Antennular peduncle exceeding eyes by most or all of terininal segment. Acicles of antennae equaling or 
exceeding eyes, 1lagellum long, nude.

Right cheliped not much larger than left. Fourth pereiopods tending towards subchelate; rasp of propodus un1serlate. Fifth perelopods subchelate, distal rasp small.

Pleopods biramous, four in females, three in males. Telson deeply cleft at midine, armed with spinules. Left vas deferens usually forming at least one complete eircle. Right vas deferens not normally protruding.

G1Il palrs 11; West Indian specles with gill lamellae quadriseriate, 111form at tips.

\section{Key to Species}

1. Carpus and chela of right cheliped armed on faces and margins with abundant spinules..................1sis. Right cheliped armed with a few feeble denticles......2. 2. Antennal flagella exceeding perelopods by one-half. Eyestalks lacking a proximal sweling..........edwards1. Antennal Plagella only equallng pereiopods. Eyestalks swollen on proximal half. dispar.

\section{Solropagurus dispar Stimpson}

Sn1ropagurus dispar St1mpson, 1858, p. 88. --Gordan, 1956, p. 341. -W Not Sriropagurus dispar M11ne Edwards and Bouvier, 1893, p. 118, pl. 9, 11gs. 1-6.

Sniroragurns caribbensis Milne Edwards and Bouvier, 1893, p. 116, pl. 8, r1gs. 26-30. --Monod, 1939, p. 560. -Gordan, 1956, p. 341.

MATERIAL EXAMINED: Twolve specimens from nine localities. 
South Carolina: $32^{\circ} 34^{\prime} \mathrm{N}, 7^{\circ}$ O5' W.; 19 fms.; Mar. 9, 1940, "Pellcan" sta. 194-10, 1 male.

Flor1da: $30^{\circ} 19^{\prime} \mathrm{N} ., 86^{\circ} 15^{\prime} \mathrm{W}_{0}, 12$ Ims.; Mar. 4, 1939; "Pellcan" sta. $141-1,1$ male. $29^{\circ} 281$ N., $85^{\circ} 31$ ' W.; 12 Ims., Fob. 1, 1956; "A. A. Jakkula"; 2 males, 1 female. Deadman Bay, $29^{\circ} 35^{\prime} \mathrm{N} ., 83^{\circ} 56$ ' W.3 9t Pms.; Nov. 7, 1901; 1 male. Tortugas; $20 \mathrm{ft}$; June 11, 1925; W. L. Schmitt, 2 males, three $\mathrm{m} 1$. north of Loggerhead Key on shoals; 10-25 ft.; W. B. Taylor; I ovig. Pemale. Tortugas; 16 fms.; J. B. Henderson, 1 male. E1ght mi. east of Dest1n, Fla.; $14 \mathrm{fms} .3$ 0et. 1941, T. J. MeGinty; 1 male.

Cuba: "from sponge"; Apr. 8, 1931, P. Bartsch, 1 male. Bahamas: Off Mathew Town, Great Inagua Id.; August 1, 1938; R. A. MeLean and B. Shreve; I male.

Puerto R1co: Ponce; Jan. 30, 1899, "F1sh Hawk", 1 male (found with types of Pagurus marshi Benedict). Flannegan Passage; 27 fms.; "Blake" sta. 152, I male (type of S. caribbensis).

RANGE; South Carolina, eastern Gulf of Mexico, to Guadeloupe; $20 \mathrm{ft}$. to $27 \mathrm{fms}$.

DIAGNOSIS, Eyestalks swollen on proximal hale. Antennal flagella equaling pereiopods. Dactyl of second pere1opod with two ventral rows of stiff setae and a more dense dorsal row.

DESCRIPTION: Shleld slightly wider than long, evenly convex. St1ff setae appear in patches on each side of gastrie 


\section{4.}

region, just behlnd marginal depressions, on rostrum, postcervical plate and along sides of entire carapace.

Eye stalks somewhat swollen on lower half; cornea less swollen than in S. edwards1. Eye scales minutely bifid at t1ps. Antennal and antennular peduncles sim1lar to those of edwardsi but shorter in relation to eyes; ac1cle more setose. Antennal flagellum not reaching tips of walking legs.

Major chela has low spines and denticles on inner margin of carpus and propodus, short spines on anteroventral angles of merus. Chelipeds differ from edwardsi chlefly in fine setae covering much of dorsal and lateral surfaces, particularly on hands. After two years in alcohol one chela st11l shows a narrow orange-red line on hand at bese of dactyl and a transverse line on each finger about one-third of length from tip.

Walking legs with rows of sparge setae; dactyl much less setiose than in edwardsi but with a row of Ilne, corneous spinules on inner ventral margin. Fourth perelopods similar to those of edwardst but much more setose. Propodus of Plfth has a much more extensive rasp than in edwardsi.

Vas deferens appears enclosed in a curved tube not reaching carpus of elfth pereiopod, from this tube it protrudes far enough to form a sinall c1rele. External ramus of unpalred pleopods one-th1ra as long as internal. Telson bordered by two diagonal plates, well armed distelly.

MBASUREMENTS (mm.): Shield, length 2.8, width 2.8, 
carapace length 4.4, width 1.6, einger 1.8, 3rd. leg, merus 2.5, carpus 1.1, propodus 2.5, dactyl 4.0.

\section{Spiropagurus edvards1 n. sp.}

Spiropagurus dispar? Milne Edwards and Bouvier, 1893, p. 118, p1. 9, 11gs: 1-6.

MATERIAL EXAMINED; Male holotype, MC2 126688, south of Cuba; $22^{\circ} 361^{11}$., $78^{\circ} 19^{\prime}$ W. $3235 . ;$ Apr. 28, 1939, "Atlant1s" sta. 3401. Male paratype (MCZ 4006), Barbados; $100 \mathrm{fms.3}$ "Hassler", (Splronagurus dispar of Milne Edwards and Bouvier, speeimen now m1ssing chelipeds as well as ac1eles).

RANGE; Cuba to Barbados; 100 to 235 fms.

DIAGNOSIS: Eyestalks not swollen on lower half, cornea greatly swollen. Antennal plagellum exceeding perelopods by one-half. Dactyl of walking legs with two rows of long, closely spaced setae, all short-plumose on one slde except near dactylar tip.

DESCRIPTION: Shleld slightly wider than long; smooth and evenly convex; rostrum rounded, equaling spine-tipped lateral teeth. Cardiac plate lightly calcleled, narrowed at midpoint. Gill cover membranous; right in holotype conceals an isopod half again as long as shleld of carapace.

Eyes shorter than shleld, stalks narrowest at base, eveniy swollen to base of cornea, latter expanded to twice 


\section{6.}

wiath of base of stalk. Eye scales narrow, bifld distally Into two spines; widely separated.

First segment of antennal peduncle with a spine on each anterior angle. Distal segment exceeds cornea by over half its length. Acicle exceeding eye, armed with a lew weak spinules on inner margin. Antennal plagellum nude, exceedIng chelipeds by more than length of carpus and propodus. Antennular peduncles exceeding eyes by most of last segment.

Chelipeds slender; each armed on merus with two spines: at each anteroventral angle; carpus with a row of about eight spines on both dorsal angles. Chelae with a row of small spinules on Inner dorsal margin of each hand, sparse Iringes of setae on both sides. Fingers narrow, meeting along entire gape; teeth minute on minor chela, larger and widely spaced on major chela.

Walking legs long, slender; fine spinules appear dorsalIy on carpus, Inner side of propodus and on dactyl. Setae near tips of dactyl stiff, tips long, sharp, pale in color. Fourth perelopods short; uniserlate rasp of about nine seales on lower margin of propodus. Propodus of fifth perelopods subchelate, with a rasp on margins of distal half. Projecting plate between bases of third pair of perelopods over twice as wide as long, with about ten spinules on leading edge. Sternal plate between fourth pair long and narrow.

Vas deferens makes about $1 \frac{1}{2}$ turns and exceeds fifth perelopod. Unpaired pleopods feeble, with a short external 
ramus, Telson almost syametrical; tip bilobed and spinu1ose.

Th1s species is named in memory of Alphonse Milne Edwards, who, together with E. L. Bouvier, did the most 1mportant work on the Caribbean pagurids to date.

MEASUREMENTS (m.). Holotype male; shleld, length 2.2, wiath 2.4 ; carapace length 3.5 , eyes 1.6 , major chela, length 3.3, wiath 1.1, finger 1.5, third leg, basis-1schium 1.2 , merus 2.8 , carpus 1.5 , propodus 3.0 , dactyl 4.7 .

\section{Solronagurus 1ris (A, Milne Edwards)}

So1ronagurus 1ris A. M1Ine Edwards, 1880, p. 44. -Gordan, 1956, p. 341.

RANGE; Barbados to Grenada; 73 to 103 fms.

DIAGNOSIS: (After Milne Edwards and Bouvler, 1893). Shield with a narrow raised margin between lateral teeth, latter triangulate, in advance of obsolescent rostrum.. Byes very dilated, much shorter than frontal margin. Eye scales broadened at bases, b1f1d at tips. Antennular peduncles exceeding eyes by all of terminal segments. Second segment of antennal peduncle with an unusually long outer spine; acicle easily exceeding eyes.

Sternal plate separating outer maxillipeds w1th a small median indentation; merus of third maxillipeds with a strong distal spine. 


\section{8.}

Chela of chelipeds armed vith small spines dorsally and in regular margins. Carpus well armed with spines, merus with a few splnules. Walking legs strong and much longer than chellpeds, dactyls much longer than propodus. Vas deferens strong and colled on 1tself.

\section{Genus Smnogurus Henderson}

Th1s genus is separated from the genus Paranagurus only on the basis of having biseriate rather than quadr1seriate g11ls. Since some evidence of intergradation between these two genera exists, it is somewhat doubtful as to whether they should be separate genera (Milne Edwards and Bouvier, 1893).

In both genera the shield tends to be broader than long, with fow Indentations and the rostrum a broad triangle exceeding the obsolescent lateral teeth. The eyes in Symagurus are usually stronger, with the cornea swollen. In both the antennal Plagellum tends to exceed the pereiopods.

The right chela is much larger than the left with both often covered with a fine pubescence. The walking legs are long; the dactyl much longer than the propodus. The propodal rasp of the fourth perelopods is usually composed of several rows of minute scales but both genera have at least one specles with a single row.

A female opening occurs only on the third left coxa. Males present two pairs of gonopods. 
Key to Species

1. Face of major chela obscured by setae..............2.

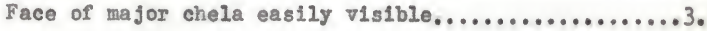

2. Chelipeds entirely covered, except at Iingertips, with Ilne, pllose ha1r........................pletus.

Only dorsal surface of major chela and carpus obscured by setae.............................. pllimanus.

3. Major chela with a strong ridge of denticles running from midpoint at base of hand to angle of cutting edges of fingers; ridge separated from sharp dentate inner margin by a broad depression..........pleristatus.

Major chela with only woak denticles above and without a groove............................. arcuatus.

Empagurus arcuatus M1lne Edwards and Bouvier

Svmeagucus arcuatus Milne Edwards and Bouvier, 1893, p. 67, pl. 5, 11gs, 21-28, --Gordan, 1956, p. 341.

Pvlonagurus exaulsetus Boone, 1927, p. 71. --Gordan, 1956, D. 340 .

MATERIAL EXAMINED: Elght specimens from four stations; Holotype female: St. Lucia; 164 Ims.; "Blake" sta. 218. Oef Honduras, North of Gorda Bank; $16^{\circ} 39^{\prime}$ N., $82^{\circ} 29^{\prime}$ W., 225 Pms.; Aug. 21, 1957, "Oregon" sta. 1870, 3 males. Oef mouth of Orinoce River: $09^{\circ} 45^{\prime} \mathrm{N} ., 59^{\circ} 45^{\prime} \mathrm{W} .3$ 200 fms.; Nov. 4, 1957; "Oregon" sta. 1989; 1 male.

Oef mouth of Amazon Rivers $01^{\circ} 45^{\prime} \mathrm{N} ., 46^{\circ} 46^{\prime} \mathrm{W}, 275$ fms.; Nov, 18, 1957; "Ogegon" sta. 2084; 2 males, 1 ovig. female. 
RANGE; (In western Atlant1c). Western Caribbean to mouth of Amazon, 138 to 275 fms. Also found as subspecies in Arabian Sea, Indian Ocean and Antarctic regions.

DIAGNOSIS: Walking legs longer than body. Major chela with dentate inner and outer ridges; sparsely pubescent above. Corneas moderately swollen.

DESCRIPTION: Shield evenly rounded in back. Rostrum rounded, scarcely exceeding lateral teeth. Eyes small, swollen at corneas. Eyo scale small, forming a strong spine. Antennular pedunele long, exceeding eye by elongate terminal segment. Base of antennal peduncle with minute outer spinule; second segment with a sharp spinule on inner angle and at tip of outer projection; fourth segment with alstodorsal spinule; terminal spinule not exceeding cornea. Aclele strong, with ten spinules on inner margin. Flagellum often exceeding perelopods, nude except for long stiff setae at three or four points.

Major cheliped with ten strong teeth on inner ventral angle of merus. Dorsal surface of carpus finely dentate above; several short spines on inner distal margin. Merus and carpus with dense pubescense below, cheliped sparsely pubescent elsewhere. Chela with inner and outer margins of sharp denticles. Subchelate dactyl closing without a gape. Minor cheliped small, armed with a single distodorsal spine on carpus. Chela slender, eurved, with long dactyl. Walking legs long, unarmed; dactyls especially long, 


\section{1.}

each with crest of strong setae on Inner dorsal edge; claw very minute, Rasp on propodus of fourth perelopod a single row of scales. Propodus of flfth subchelate with triangular rasp fronting on distal dorsal margin. Male gonopods feeble, unpa1red pleopods with a slender, minute outer ramus. Telson asymetrical, larger left lobe armed with corneous spinules.

MEASUREMENTS (m.): Male from "Oregon" sta, 1870: Shield, length 4.5 , width 4.5 , carapace 6.8 , eyes 3.3 ; major chela, length 9.0, wiath 7.0 , dactyl 6.2 ; minor chela, length 5.0, width 1.3, dactyl 2.5; thira perelopod, basis1sch1um 2.9, merus 4.6 , carpus 4.6 , propodus 4.8 , dacty 9.6 .

Sympagurus bicristatus (A, Milne Edwards)

Eupagurus? bleristatus A. Milne Edwards, 1889, p. 43. Sympagurus b1eristatus M1Ine Edwards and Bouvier, 1894, p. 69, pl. 11, P1gs, 1-15. --Gordan, 1956, p. 341. RAWGE: Virgin Ids., eastern Atlantic, Mediterranean Sea and Indian Ocean; 218 to $835 \mathrm{fms}$. (taken once at $54 \mathrm{fms.).}$ DIAGNOSIs: (after Milne Edwards and Bouv1er, 1893).

Shield well calcifled, distinctly separated from branch1 al regions. Spine terminating third article of antennal peduncle larger than in $\mathrm{S}$. areuatus.

Denticles on merus and carpus less pronounced except on ventrodistal border of carpus. Hand short, high, and 


$$
242 .
$$

bordered dorsally by two parallel crests of denticles, the Inner more elevated than the outer.

\section{Symagurus Dictus Smith}

Sympagurus nictus Smith, 1883, p. 37, p1. 5, rigs. 2, 2a, p1. 6, 11gs, 5-8, --Gordan, 1956, p. 342. --Springer and Bull1s, 1956, p. 16.

MATERIAL EXAMINED: Seven specimens from f1ve stations. off Missission Delta: $29^{\circ} 10^{\prime} \mathrm{N}$., $88^{\circ}$ 08' W.s $240 \mathrm{Pms}$. "Oregon" sta. 1564, June 22, 1956, 3 ovig. females in anemones, Paracalliactus involvans (MoMurrich).

Caribbean Sea: West of Rosalind Bank, $16^{\circ} 35^{\prime}$ N., $80^{\circ}$ $55^{\prime}$ W.; 100 fms.; Aug. 24, 1957; "Oregon" sta, 1890, 1 male. Barbados; 288 Ims., "Blake" sta. 987; 1 male.

ore Irinidad: $10^{\circ} 00^{\prime} \mathrm{N} ., 59^{\circ} 59^{\prime}$ W. $\left._{0} 250 \mathrm{fms}.\right\}$ Hov. 3, 1957; "Oregon" sta. 1892, 1 male.

oef Surinam: $07^{\circ} 40^{\prime} \mathrm{N}_{0}, 54^{\circ} 47^{\prime}$ W.3 300 Ims.; Nov. ?, 1957; "Oregon" sta. 2009; 1 male from shell of Leucosyring edgariana Dall.

RANG: Massachusetts to Surinam; 100 to 315 fms. In Gulf of Mexico found thus far only in northern part from Texas to Florida.

DIAGNOSIS: A large specles, Chellpeds long, covered by a dense, fine pubescence; walking legs almost nude. Dactyl of fourth perelopod longer than propodus. 


\section{3.}

DESCRIPTION: Shield broader than long; well marked median line becoming a ridge on rostrum. Latter prominent, almost equaling ophthalmic ring. Lateral teeth obsolescent. Cardiac plate narrow, poorly calcleled. Carapace on elther side of cardiae plate uncalcifled but stiff and rough, margined by halr. G111 covers membranous, with dense plumose ha1r on lower parts.

Eyes short, swollen at cornea; stalks constricted in midregion. Eye scale small, forming stout, terminal spine. Antennular peduncles slender, exceeding eyes by most of terminal segment. Antennal peduncle scarcely exceeding eye; second segment armed with a denticle on inner angle, six denticles on inner dorsal margin of stout, outer projection. Acicle strong, feobly armed on distal inner margin. Flagellw nude, exceeding perelopods.

Chelipeds simllar except in proportion; strong denticles on upper surfaces obscured by dense coat of feathery hair completely covering both chelipeds. Cutting edges of IIngers composed of strong teeth. Larger teeth faced with minute denticles. General arrangement similar to pagurus with row of corneous teeth on distal part of dactyl meeting several calcareous teeth on pollex. Minor chela slender, with cutting edges gaping along proximal fourth; corneous edges of pollex unsupported by calcareous teeth.

First walking leg denticulate on ventral margins of ischium and merus, both armed with distodorsal spinule on 


\section{$24 \%$.}

carpus. Dorsal surfaces of three distal segments bear several short setae; those on dactyli heavier and forming a dense row distally; I Ive transverse rows appear on inner distal surface of dactyl. Propodus of fourth perelopod w1th rasp of minute, sparse scales in four rows on distal two-thirds of ventral edge. Dactyl unusually developed, longer than any other segment; row of very minute scales along ventral angle. Subchelate propodus of flfth perelopod with a somewhat trlangular rasp on distal three-fourths.

First pair of male gonopods short; second pair long, heavy; both palrs broad-spatulate distally. Unpaired male pleopods with a short outer ramus. Telson asymmetrical, scarcely eleft medially; armed with corneous spinules.

COLOR; A distinctively marked species with a large patch of burnt orange on outer surface of merus of each walking leg. Similar but less intense color appears on shield and posterior abdominal plates. Cornea and short dorsolateral stroak on eyestalk Indian red. Paddle-shaped calcareous plate on upper surface of each eyestalk. Dactylar setae of walking legs scarlet.

MEASUREMENS (m.): Male from "Oregon" sta. 1982. Shleld, length 13, width 15 , carapace 22, eyes 7.5 ; major chela, length 32 , width 12.5 , dactyl 16.5 , minor chela, length 19.5, width 6 , dactyl 13, third perelopod, basis1schium 10, merus 18.5 , carpus 11 , propodus 19 , dactyl 26.5 . 
Symagurus D1limanus (A. M1lne Edwards)

Eunagurus D111manus A. M11ne Ed̂wards, 1880, p. 43.

Sympagurus D11imanus M1Ine Edwards and Bouvier, 1893. -Gordan, 1956, p. 342.

MATERIAL EXAMINED: S1xty-eight specimens from 35 stations in five areas.

Types: Male; Guadeloupe; 171 Ims.; "Blake" sta, 167. Female; St. Kitts; 208 Pms.; "Blake" sta. 148.

Texas: $27^{\circ} 43^{\prime} \mathrm{w}, 9^{\circ} 05^{\prime} \mathrm{W}_{0} 3300 \mathrm{fms} .3$ May 6, 1956, "Oregon" sta, 1507; 1 male.

Southeastern Florida: $27^{\circ} 28^{\prime} \mathrm{N} ., 78^{\circ} 44^{\prime} \mathrm{w}_{\text {., }} 215 \mathrm{fms}$, ; Feb. 3, 1957, "Combat" sta, 237; 1 ov1g. Semale; $25^{\circ}$ o7 $\mathrm{N}$. , $79^{\circ} 15^{\prime}$ W. $3_{0} 300$ fms.; July 23, 1957, "Combat" sta. 447,1 Pemale, $24^{\circ} 35^{\prime} \mathrm{N} ., 79^{\circ} 58 \mathrm{l}^{\mathrm{W}}$.; 565 Pms.3 July 25, 1957; "Combat" sta. 452, 1 male.

Cuba: "Atlant1s" stations: $26^{\circ} 08^{\prime}$ No, $79^{\circ} 02^{\prime} \mathrm{W}_{0}, 155$ fms.; Feb. 3, 1958; sta. 2951, 2 males, 4 females (3 ovig.). $22^{\circ} 48^{\prime}$ N., $78^{\circ} 41^{\prime} W_{03} 220-260$ fms, ; Mar. 10, 1938, sta. $2980 \mathrm{~A}$; 1 male, 2 females ( 1 ovig.). $22^{\circ} 48^{\prime} \mathrm{w} ., 78^{\circ} 48^{\prime} \mathrm{W}, 3$ 220-225 Ims. 3 Mar. 10, 1938, sta. 2980B, 2 males, 2 ov1g. females. $22^{\circ} 47^{\prime} \mathrm{N}_{0}, 78^{\circ} 49^{\prime} \mathrm{W}_{.}, 195$ Ims.g Mar, 10, 1938, sta. $2981 \mathrm{C}$; 1 male, 1 ovig. Pemale. $22^{\circ} 48^{\prime} \mathrm{N} ., 78^{\circ} 50^{\prime} \mathrm{W}$, s 210 fms.; Mar. 11, 1938, sta. 2982A; 3 males, 2 females (1 ov1g.). $22^{\circ} 44^{\prime} \mathrm{N},, 78^{\circ} 41^{\prime} \mathrm{W}_{0}, 150-180$ fms. 3 Mar. 11, 1938;

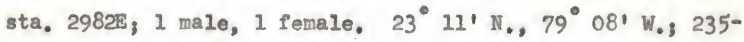
260 Pms.; Mar. 12, 1938; sta. 2983; 2 males. $23^{\circ} 10^{\prime} \mathrm{N}_{\text {., }}$ 


\section{6.}

$81^{\circ} 29^{\prime} W_{0}, 145-230$ Ims. 3 Mar. 17, 1938, sta. 2999; I male. $22^{\circ} 13^{\prime} \mathrm{N}_{\text {., }} 81^{\circ} 11^{\prime} \mathrm{W}_{0} ; 185$ Ims,; Apr. 4, 1939; sta. 3320; 1 ovig. Pemale. $20^{\circ} 45^{\prime} \mathrm{N} ., 75^{\circ} 20^{\prime}$ W. 230 fms.; Apr. 20,1939 ; sta. 3375,2 males, $22^{\circ} 33^{\prime} \mathrm{N} ., 78^{\circ} 10^{\prime} \mathrm{W}_{\bullet} ; 245$ Pns.; Apr. 26, 1939; sta, 3387, 1 male. $22^{\circ} 34^{1} \mathrm{~N}_{0}, 78^{\circ}$ 14' W.; 200 fms.; Apr. 27, 1939; Sta. 3394; 1 male. $22^{\circ}$ 35 ' N., $78^{\circ} 19^{\prime} \mathrm{W}_{0} ; 180 \mathrm{fms}, ; \mathrm{Apr}, 28,1939$; sta. 3400, 1 male, $22^{\circ} 50^{\prime} \mathrm{N}_{0}, 78^{\circ} 50^{\prime}$ W.; 215 Ims.; Apr. 29, 1939; sta. 3413; 1 male, 1 ovig. Pemale. $22^{\circ} 50^{\prime} \mathrm{w} ., 78^{\circ} 55 \mathrm{w}^{\circ}, 200$ Ims.; Apr. 30, 1939; sta, 3416,2 males, $22^{\circ} 50^{\prime} 78^{\circ} 56^{\prime}$ W.; 200 Pms.; Apr. 30, 1939, sta. 3417, 1 male, 1 female.

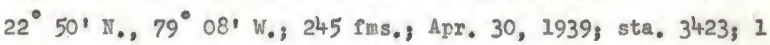
ovig. Semale, $23^{\circ} 05^{\prime} \mathrm{N} ., 79^{\circ} 32^{\prime}$ W.; 260 Pms.; May 2, 1939; sta. 3437,1 ovlg. Pemale. $23^{\circ} 13^{\prime} \mathrm{N} ., 81^{\circ} 22^{\prime} W_{0} ; 385$ Ims.s May 11, 1939; sta. 3485 ; 1 male.

Rosalind Banks $16^{\circ} 38^{1} \mathrm{~N}, 8^{\circ} 34^{\prime} \mathrm{W} .3$ 205-210 fms.; Aug. 21, 1957; "Oregon" sta. $1869 ;$ I female. $16^{\circ} 39^{\prime} 11 .$, $82^{\circ} 29^{\prime}$ W.; 225 fms.; Aug. 21, 1957; "Oregon" sta. 1870; 1 female.

RANGE: Texas and Florlda to Rosalind Bank and Guadeloupe; 155 to 565 Ims.

DIAGNOSIS: Eyes short, strong, dilated distally; a calclfled, dorsal strip on stalk. Chellpeds covered with pla1n and pllose setae dorsally. Major chela large, oval. DESCRIPTION: Shield smooth, almost nude; a low median ridge on anterior half. Rostrum obsolescent, exceeding 


\section{7.}

scarcely noticeable lateral teeth but leaving ophthalmic ring exposed. Cardiac plate narrow, vase-shaped.

Eyes short, Plattened; broadened distally. Bye scales minute, in shape of a small spine. Antennular peduncles exceeding eyes by most of terrinal segment. Antennal peduncles equaling eyes; second segment with a strong outer spine, none on inner angle. Acicie subequal to terminal segment; two or more inner spinules. Flagella equaling perelopods, nude except for two or more ine setae at intervals.

Najor chellped much larger than minor. Dorsal surfaces covered with both simple and pilose setae which almost obscure armament of chela. Latter with short spines on margin and in two rows on face of manus. Teeth on cutting edges of fingers ealcareous and strong. Minor chellped with a dorsal and outer distal spine.

Walking legs armed only with a distodorsal spinule on carpus. Dactyls long, slender, twisted outward at tIps, with strong distal setae alding formation of walking surfaces. Claws short, bent slightly upward. Fourth perelopod with three rows of seales on propodal rasp; fifth subchelate, with a rasp on distal three flfths of propodus. External ramus of male pleopods represented by a minute papilia. Telson asymetrical, lightly armed distally.

COLOR: Eyestalks dull red except on calclfled dorsal strip. 


\section{3.}

MEASUREMENS: (m, ): (Female from "Combat" sta, 4'47). Shield, length 8.0 , w1ath 8.0 ; carapace 13.0 , eyes 5.8 ; right chela, length 15.0 , width 10.0 , dacty 7.5 ; left chela, length 9.5 , width 3.2 , dactyl 6.0 , third right perelopod, basis-ischium 6.4, merus 10.2, earpus 7.2, propodus 9.0 , dactyl 14.6 .

\section{Genus Tomonaguroides Balss}

\section{Tomoneguroldes valdivie Balss}

Tomonagurolies valdiviae Balss, 1926, p. 104. --Gordan, 1956, p. 342 .

MATERIAL EXAMINED: $23^{\circ} 21^{\prime} \mathrm{ll} ., 80^{\circ} 36^{\prime} \mathrm{W}, 300 \mathrm{fms} .3$ May 4, 1939; "Atlantis" sta. 3459, 1 ovig. female, MCZ 126687. $23^{\circ} 23^{\prime} \mathrm{NT}, 8^{\circ} 21^{\prime} \mathrm{W}, 3$ '75 rms.; Mar. 14, 1938; "Atlant 1s" sta. 299, I female, KCZ 26680, $20^{\circ} 49^{\prime} \mathrm{N} ., 75^{\circ}$ 08 ' W., 600 Ims.; Apr. 20, 1939; "Atlentis" sta. 3369, I female, MCZ 126683.

RANGE: Cuba, north of Santa Clara and Orlente provinces; 475 to 600 Ims.

DIAGNosis: Shield subquadrate; eyes reduced, cornea lacking pigment. Perelopods hairy on dorsal surfaces. Right chela almost twice as wide as left, slightly longer.

DESCRIPTION: Shleld as wide as long, nearly smooth; frontal margin ralsed, especially between lateral teeth. Rostrum and lateral teeth tipped with spines, subequal. 


\section{7.}

Gastric region outlined by a few tufts of bristles. Posterolateral borders each flanked by a narrow, calcifled plate. Cardiac plate narrow, short; gill covers partially calcifled above, with a few scattered setae. Eyes less than half as long as shield, with a bowling pin shape; cornea feebly dilated. Eyestalks w1th a thick row of setae directed medially and forward on dorsal surface. Antennular peduncle exceeding eyes by terminal article and half of next. Base of antennal peduncle with a spinule on outer margin. Second segment denticulate on inner angle; outer lacking spines, a row of setae on inner edge. Acicle reaching near enc of peduncle; latter exceeding eye by terminal article. Flagellu surpassing perelopods, narrowed to a fllament and more setose distally.

Right cheliped heavier than left, slightly longer. Ischlum and merus with denticles on Inner ventral margin; carpus and propodus denticulate on Inner dorsal surface near their articulation. Upper surface of carpus and propodus evenly covered with fine setae which hold silt on surfaces. Fingers of major chela meet only at heavy, corneous tips. Both fingers present two strong crushing teeth behind distal corneous edges. Minor chela with fine corneous teeth distally on two-thirds of dactyl and half of pollex; fingers meet closely only on distal half.

Walking legs similar. Carpus with a stout denticle on distodorsal angle. Dactyl shows an even row of setae along 


\section{0.}

lower inside surface; on the first leg this row is a series of turts rising from punctae; on the second it consists of about 14 diagonal, overlapping, combs. Dorsal surfaces of propodus and dactyl densely setose. Tip of dactyl short, sharp and corneous.

Propodus of fourth pereiopods with a narrow rasp two or three scales wide on distal three-fourths; dactylar rasp uniseriate. Prominent iriction points on distal ventral and dorsal angles of carpus allow only a sidewise movement of propodus. Subchelate propodus of eifth pair with a rasp on distal three-fifths of outer surface and a dense patch of setae on lower side.

Sternal plate separating third maxillipeds presents two prominent teeth medialy. Eggs resemble elusters of grapes, about 40 on each pleopod, each egg about $1.8 \mathrm{~mm}$. In diameter. Telson symetrical, Peebly armed.

\section{Genus Tomonaguronsis Alcock}

Tomonaguronsis nroblematice (Milne Edwarde and Bouvier). Eunagurus? problematicus Milne Edwards and Bouvier, 1893, p. 151, pl. 11, 11gs, 1-10.

Tomonagurons1s nroblematica Alcock, 1905, pp. 137-190. --Gordan, 1956, p. 342.

MATERIAL EXAMINED; Nine specimens from elght stations. Male holotype: off Sand Rey, Fla.; 125 fms.; Apr. 13, 1872; "Bache.." 
3off Cape Lookout; N.C.: $13 / 4 \mathrm{mi}$. N.E. of 11ght; $7 \frac{t}{2}$ Ims.; July 24, 1902; "Fish Hawk" sta. 7302.

Stralts of Florida: $25^{\circ} 12^{\prime} \mathrm{N}_{.}, 80^{\circ} 00^{\prime} \mathrm{W}_{.3} 185 \mathrm{fms.;}$ July 25, 1957, "Combat" sta. 453; 1 female from shell of Genota Ylabrunnea Da11.

Cuba: $23^{\circ}$ O5' N., $79^{\circ} 37^{\prime} \mathrm{W.j} 265$ fms.; May 2, 1939; "Atlant1s" sta. 3438, I male. $22^{\circ} 08^{\prime} \mathrm{N} ., 81^{\circ} 10^{\prime} \mathrm{W}_{.3} 260-$ 275 fms.3 Apr. 5, 1939; "Atlant1s" sta. 3328, 1 female.

Caribbean Sea, North of Gorda Bank; $16^{\circ} 39^{\prime} \mathrm{N}_{0}, 82^{\circ}$ $29^{\prime} W_{. ;} 225$ fms.; Aug. 21, 1957; "Oregon" sta. 1870, 1 male, 1 female. $16^{\circ} 38^{\prime}$ N., $82^{\circ} 34^{\prime} \mathrm{W}, 3$ 205-210 Pms.; Aug. 21, 1957; "Oregon" sta. 1869, I male.

Off mouth of Orinoco River: $09^{\circ} 45^{\prime} \mathrm{N} ., 59^{\circ} 45^{\prime} \mathrm{W} .3$ 200 Ims.; Nov. 4, 1957; "Oregon" sta. 1989; 1 male.

RANGE; ? Cape Lookout, N.C. to mouth of Orinoco RIver

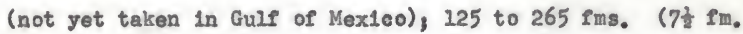
record doubteul).

DIAGNOSIs; Chelipeds not markedly different. Antennal flagella and dorsal surfaces of perelopods quite setose. Eyes small, scarcely swollen at cornea.

DESCRIPTION: Shield convex in each direction. Rostrum trlangular, exceeding lateral teeth. Cardlac plate in shape of an Inverted $Y$. Eyes shorter than shield, faintly swollen at both ends. Eye scales rounded above, curved outward at t1ps. Antennular peduncles exceeding eyes by half of terminal segment. Antennal peduncle equaling eyes; second segment with 


\section{2.}

an Inner spinule, another on Inside near tip of outer projection. Aclele at least equaling eye.

Carpus and propodus of major chellped finely pubescent dorsally with sparse long setae; surfaces even except for seattered low denticles and an inner dorsal ridge with strong, calcareous spines. Opposing edges of fingers differ from pattern found in genus Pagurus. Pollex with large medial tooth opposing shallow depression on dactyl. Proximal edge of dactyl w1th three strong teeth, largest most proximal. Edges distal to large tooth on pollex, both corneous, includIng heavy tips. Minor cheliped similar to larger except for short row of strong denticles on distodorsal surface of carpus and stralght cutting edges of Plne, corneous teeth on eingers.

Walking legs unarmed, densely setose above; claws P1ne, short. Propodus of fourth perelopod with a trlangular rasp on distal half of ventral surface, dactyl with falnt row of scales. Propodus of fifth perelopod covers most of distal half of outer surface, Plate separating th1rd maxillipeds with a median cleft planked on each side by a strong spine, as in Munidonagurus. Asymmetry marked on ventral part of thorax; coxal pairs well separated. Telson with left lobe more produced, both lobes armed with recurved corneous spinules. Male gonopods quite small, well separated basally. Unpatred pleopods of male with outer ramus a third as long as Inner. 
COLOR: (Male from "Oregon" sta. 1989 in formalin). Perelopods, head appendages, and shleld mainly livid pink, setae straw yellow.

MEASUREMENTS (m.)) Female from "Combat" sta. 453; shleld, length 5.5 , width 5.2 , carapace 8.5 ; eyes 3.5 ; major chela, length 10.0 , width 5.1 , dactyl 5.7, minor chela 8.0 , third perelopod, basis-ischium 3.6 , merus 4.4 , carpus 4.0, propodus 4.4, dacty 8.0 .

REMARKs, The male from "Oregon" sta. 1989 lacks gonopods, wh1le the male Prom "Oregon" sta. 1870 has both gonopods present and also has an opening on the third right coxa.

Genus Tonopagurus M1Ine Edwards and Bouv1er

Tomonagurus rubronunctatus Milne Edwards and Bouvier

Tomonagurus rubronunctatus Milne Edwards and Bouvler, 1893, p. 71, p1. 6, figs, 1-6. --Gordan, 1956, p. 342.

MATERIAL EXAMINED; Holotype male at MCZ; Barbados; 73 fms.; "Blake" sta. 290.

RANGE, Known only from type.

DIAGNOSIS, (after M1lne Edwards and Bouvler, 1893). Rostrum obtuse, exceeded by acuminate lateral teeth. Eyes dilated at cornea; exceeded slightly by antennal peduncles, and by three-fourths of terminal segment of antennular peduncles. Antennal Plagella surpasses perelopods. Sternum separating external maxil11peds unarmed. 


\section{4.}

Major chela with face convex and covered with arced spines; marginal spines strongest. Minor cheliped with two dorsal rows of spines on carpus. Chela with a row of dorsal spinules and another on outer margin; smaller spinules and granules between these rows to tip of pollex. Dactyl unarmed.

A single pair of anterior abdominal appendages on male. Telson deeply eleft, lobes dentleulate distally.

REMARKS: Wh1le Tomopgeurus is clearly a valld genus, 1ts characterist1es w11l not be fully known unt1l a female is collected.

\section{Genus Xylopagurus A. M1lne Edwards}

\section{Xylonagurus rectus A. Milne Edwards}

Xvlopagurus rectus A. M1lne Edwards, 1880 , p. 37. --Schm1tt, 1935, p. 207, 11g. 67. --Gordan, 1956, p. 342.

MATERIAL EXAMINED, Two specimens from Cuba.

Cuba: $22^{\circ} 07^{\prime} \mathrm{r} ., 81^{\circ} 08^{\prime} \mathrm{W}_{\cdot} ; 155-190 \mathrm{fms} . ;$ Feb. 25 , 1938; "Atlantis" sta. 2963-A; 1 female. $22^{\circ} 13^{\prime} \mathrm{N} ., 81^{\circ} 11^{\prime}$ W.3 185 fms.; Apr. 4, 1939; "Atlant1s" sta. 3320, 1 male. RANCs; Bahia de Cochinos, Cuba, to St. Vincent; 75 to 185 fms.

DIAGNOSIS: Body elongate, adapted to living in a hollow twig. Ta1l fan forming an operculum.

DESCRIPTION: Shield glabrous, rounded laterally. Rostrum triangular, covering opthalmic somite. Cardac 
plate broader behind, shorter than shleld. Eyes short, cornea extremely dilated. Bye scales rounded, fringed with about elght teeth. Antennular peduncle strong, exceeding ejes by a third of terminal segment, those of antennae reeble, reaching midway on cornea. Flagellum eas1ly reachIng dactyl of walking legs, sparsely setose.

Major cheliped elongate, slightly exceeding walking legs. Chela heavy, feebly setose; fingers short, with large teeth. Minor cheliped feoble, just reaching major chela. Walking legs also feeble, propodus equaling dactyl. Fourth pereiopods chelate; propodal rasp broad, oval, composed of very minute scales; dactyl with ten much larger scales. Rasp of f1fth perelopods composed of large scales, covering outer surface of chela. Second pair of male gonopods stronger than first. Scales on uropodal rasps strong, recurved. MEASUREMENTS $(\mathrm{mm}$.$) : Shleld, length 3.7$, width 2.4 , carapace 5.9 , eyes 2.5 , right chela, length 5.7 , width 2.4 , dactyl 2.0, left chela, length 3.1 , width 0.7 , dactyl 1.8 , third perelopod, basis-1sch1um 2.3, merus 3.7 , carpus 1.8 , propodus 4.0 , dactyl 4.0 .

REMARKs; The sharp denticles on the projection at the base of the dactyl in the major chela probably ald, along with the rasps of the uropods, In forming a hole in a twig. The body and appendages are symmetrical except for the chelipeds. 


\section{ZOOGE OGRAPHY}

\section{Physlography of the Area}

The vast body of water and long coastline between Cape Hatteras, North Carolina, and the mouth of the Amazon R1ver seems to present relatively few effective barriers to the distribution of hermit crabs. The region is characterized by extensive shallows extending far of fshore in a few areas and by deep water near shore at numerous points. The continental shelf is broad along the Carolinas and Georgia, the west coast of Florida and the northern coast of the Gulf of Mexico except at the mouth of the Mississippi River. An extensive shelf also occurs along the northern and western coasts of Yucatan and east of Honduras and Nicaragua. The Little Bahama and Great Bahama Banks, the Golfo de Batabano between Cuba and the Isle of PInes, and the Golfo de Guacanagabo further east along the southern coast of Cuba are large areas with depths generally under f1ve fathoms.

The remaining coastal areas, those off southeastern Florida, eastern Mexico, Brit1sh Honduras, Costa R1ca, Panama, northern South America, and the 1slands of the Caribbean generally have very narrow shelves, with the 1,000 fathom line usually not too far offshore. The shelf along the eastern coast of South America north of the mouth of the 
Amazon is more extensive than in the areas just mentioned. Shorelines along the reglons of extensive shallows are Inclined to be of mud or PIne sand with slight wave action. Swampy areas and tidal estuaries oceur along this type of coast in sheltered areas. Coral growths and sponge banks are found at many points from North Carolina and northwestern Florida south through the Caribbean.

\section{Environmental Relationships}

Varlations in the ranges of hermit crabs in the western Atlantic appear to be Influenced by temperature, bottom type, and depth. Temperature is probably the 1imiting factor for those specles which are restricted to the CaroIInlan faunal province. These species are found further south along the west coast of Florida than along the east coast but have not been found at Key West or the Dry Tortugas. Seven specles found in the Gulf of Mexico and along the Carolina coast are Included in this group. Four other species are known only from the northern part of the Gulf of Mexico. Pagurus politus is an abundant species in deep water off the east coast of Florida and ranges to the Dry Tortugas but has not been found in the rest of the Gulf. Prlonagurus coral11nus oceurs from the Carolinas to the Straits of Florida and Yucatan but has not been reported south of this reglon.

At least 24 species present along the Carolinas, in the northern Gulf of Mexico, or in both areas, extend their 
range south into the Carlbbean Sea or beyond. An additional 36 species have been taken only in the Carlbbean area, ineluding the Straits of Florida. Five deep-sea species occur on both sides of the Atlant1c. Two specles, Clibanarius v1ttatus and Isocheles wrdemanns, are sound in malnland shallows from the Carolinian province to Braz1l, jet neither has been taken in the West Indian Islands. Th1s may be due to fallure of the planktonle larvae to successfully cross deep-water areas 1solating the 1slands.

Relatively fow species can be assigned to derinite bottom types on the basis of avallable information. Species whlch live on reef or shell bottoms have relatively short, heavy perelopods whlle those found on loose substrates have the perelopods elongated and slender, with the dactyls twisted and supplied with stiff setae on the margins.

Members of the fam1ly D1ogen1dae are most often found on reef or shell bottoms, at least in shallow water. Some species in the genus Paguristes definitely favor reers, Wh1le members of the genus Clibanarlus are equally common in sheltered areas. Pagurus, the largest genus of hermit crabs, is found in many habitats and often at great depths. However, only a few species of small slzes have been found on reefs. Many other species in the genus frequent shell bottons. The many species of the genus Pylonagurus are composed of rather small species or individuals, most of which are found on the lower shelf or the slope beyond it 
where they evidently find a solid substrate, since thelr walking legs are rather short. Genera adapted by long walking legs for living on soft substrates Include Parapagurus, Sympagurus, Catanagurus, Cataraguroides, and Tomonaguro1des.

A few specles are restricted to certaln shell forms or unusual objects as dwell1ngs. Examples are Paguristes spinipes, usually found in X1phosure shells; Xrloparurus, Inhablting hollowed twigs or reeds at great depths; Cancellus, which, along with several members of the Prlochelldae, IIves in hollowed siliceous sponges or stones; and those specles which carry anemones when adult. The latter Inelude at least two Parapagurus Dilosimanus and Mun1dopagurus macocheles. Species which 11ve in shells with narrow apertures include Isocheles wurdemanni, Pagur1stes sericeus, P. puncticens, $P$. mar1, P. depressus and $P$. triangulatus. Bvlonagurus discoldalis lives in scaphopod shells which may later be absorbed by an anemone. R. corallinus and its close relatives are usually housed in bryozoan colonies which absorb the original gastropod dwelling. Specles which have been found in the same bryozoan as $\mathbf{P}$. corailinus are Petrochirus bahamensis, Paguristes puncticens, Peguristonsis humm and Dardanus peters1.

Hermit crabs have been taken at depths down to 1,000 fathoms In the Caribbean, but much greater depths in other parts of the world. On the basis of species numbers, a 


\section{0.}

rather uniform distribution seems to occur down to at least 200 fms, although Individual species may be locally restricted to specific habitats. If the vertical distribution is divided Into IIve categories and species assigned to those in which they have been most frequently taken, we IInd that 20 species predominate in the 11 ttoral down to 10 Ims., 14 in the 5-50 fathom range, 16 on the lower shelf or below (50-125 fathoms), 31 at 100-250 fathoms, and seven at depths below 250 fathoms.

Faunal Relationships in the Gulf of Mexico, Caribbean Sea, Atlant1c Ocean, and Eastern Pacle1c

The numbers of genera and specles of pagurids increase strikingly toward the tropies. Only the genus Pagurus is found in the 11ttoral waters of New England while Florida has 12 genera above the ten fathom Iine. From the straits of Florida and the depths surrounding Cuba, the composition of the fauna shows no marked change through the Caribbean and south to the Gulanas.

At the species level the western Atlantic pagurids most often show affinity with the fauna of the Pacifle coast. In several instances closely related species are known which have undoubtedly evolved since the Isthmus of Panama was formed. Only a few examples of speciation within the western Atlant1c are obvious. The 15 species in the genus Paguristes form a falrly homogenous group when compared with these from 
the western coest of Africa (Forest, 1954a). Those from the Caribbean reglon have the eye scales well separated and always have both coxal openings present in the female, while several African species have the eye scales approximated and nearly all present a single coxal opening in the fomale. Paguristes puncticens, $P$. grav1, and $P$. serlceus form a very closely related group of sympatic species. Paguristes tortugae and $\mathrm{P}$. hevatti are closely related but separated geographically and without known intergrades. Only one member of the genus, Paguristes Porest1, has 1ts closest relative on the opposite side of the Atlantic.

The genus Prlongeurus, a distinctive group of small pagurids, is almost exclusively American, the number of species found on the Pacifle side of the continent possibly equaling the 15 known from the Caribbean region. Only two species, both from South Africa, are known outside of the Americas. One of these is elosely related to an American species.

Genera found only in the Caribbean are Tomopagurus, 0etopagurus, and Mun1dopagurus. Genera known from both sides of the New World but not elsewhere are Isocheles, Paguristoosis, and Xrlonagurus. Two deep-water genera which are found only in the Atlantic and adjacent seas are Catapaguroldes and Tomopaguroides. 


$$
262 .
$$

Relation to the Fauna in Other Parts of the World

Two areas of the world stand out as centers of speclation and refuges for primitive forms. These are the IndoMaylayan region with 25 genera and the Caribbean Sea and its adjoining water masses with 29. These areas have 17 genera In common. However, the Ind Ian Ocean and Maylaysian region contain far more specles in the Dlogenidae, particularly in the genera Dardanus, C11banarius, Calc1nus and Diogenes. The latter genus, a rather large one, is restrieted to the 01d World. Both reglons have many specles belonging to deep-water genera in the Paguridae. Two of these genera wh1ch oecur only in the Indian Ocean and western Atlantic are Tomonaguropsis and Prlopapuropsis. 
SUMMARY

A systematic study of the hermit crabs in the fanilles Coenob1t1dae, Pylochelldae, D1ogen1dae and Paguridae found between Cape Hatteras and the mouth of the Amazon R1ver is presented. The ninety-two species reported include all those found in the Western North Atlantic except for three specles from areas north of Cape Hatteras and one from Bermuda. The species reported are placed in 29 genera.

Complete descriptions are given for all specles studied In deta11. Dlagnoses are offered for rare or type specimens for which satisfactory descriptions exist. Keys to the genera of the world and to the included specles are presentod. Two genera and 19 specles are described as new.

Two specles and genera whlch were previously known from the eastern Atlant1c are reported from Cuba. These are Catapaguroldes microns M1Ine Edwards and Bouvier and Tomonaguroides valdiviae Balss. Cancellus tanneri, known only from the type specimen collected in the Bay of Panama, is also reported from Cuba. The genera Ceratonagurus, Cestopagurus and Prlonaguronsis are reported from the Atlantie for the first time.

The following ten species prevlously known from the Gulf of Mexico or the Caribbean are shown to occur on the Carolina coast: Dardanus renosus, Paguristes Iyman1, $P$. 


$$
264 .
$$

triangulatus, Paguristops1s humm, Pagurus defensus, $R$. impressus, Dctopagurus pygmaeus, Pylopagurus discoidalls, Sp1ropagurus dispar, and Tomopagurops1s problemat1ca. The fauna of the area studied constitutes a more or less complete un1t, the majority of specles not being found beyond 1ts 11mits. The affinities at the species level are mainly with the Pacific coast fauna. At the generic level there is some affinity with the Indo-Maylayen fauna. In the western North Atlant1e the number of specles found beyond the shelf is approximately equal to the number found on the shelf. 


\section{LITERATURE CITED}

Alcock, A.

1905. Catalogue of the Ind1an decapod Crustacea in the collection of the Indian Museum. Part II, Anomura. Fasc. I. Pagurldes. Calcutta, pp.

Balss, Heinrich 1924. Westindische Decapoden, Z001. Anz,, 61: 177-
182,5 pls.

1926. Paguriden. In Chun, Carl (ed.), w1ssenschaft$11 \mathrm{che}$ Ergebn1sse der deut scen Tle see-ExpedIt1on "Vald1v1a" 1898-1899. Jena, Gustav F1scher, 20(2): 85-124, 26 igs., 5 pls.

Behre, Ellinore $\mathrm{H}$.

1950. Annotated 11st of the fauna of the Grande Isle reg1on, 1928-1946. Occas. Papers Mar. Lab.,

Benedict, James $\mathrm{E}$.

1892. Preliminary descriptions of 37 new species of hermit crabs of the genus Eunagurus in the U. S. N. M., Proc. U. S. Nat. Mus., 15: 1-26.

1900. The anomuran collections made by the F1sh Hawk Expedition to Porto Rico. Bull. U. S. F1sh Comm., 20 (2): 129-148, 4 pls.

1901. Four new symetrical hermit crabs (pagurids) Prom the West Indlan reglon. Proc. J. S. Nat. Mus,, 23: 771-778, 7 P1gs.

Boas, J. E. V.

1926. Zur Kenntn1s symmetr1scher Paguriden. K. Danske Boone, Lee V1densk. Selk. B101. Meddel., $5(6): 1-52,25$ 11gs.

1927. Crustacea from troplcal east American seas. 265. 
BuIl, Bingham Oceanogr. Coll., New York, 1(2): $1-147,33$ f1gs.

1932. The 11ttoral crustacean fauna of the Galapagos Islands. Part 2. Anomura. Zoolog1ca, New York, 14: 1-62, is f1gs.

1938. Selent1fic results of the eruises of the yachts "Ara", 1928-1929, and "Alva", 1931-1932, "Alva" Meditérranean cruise, 1933 , and "Alva" South American cruise, 1935, William $\mathrm{H}$. Vanderbilt commandIng. Part V. Crustacea, Bull. Vanderb11t Marine Mus., 7: 197-281, 39 pls.

Bose, L. A. G.

1801. Histoire naturelle des Crustaces, contenant leur description et leur moeurs, avec f1gures dess1nees d'apres nature. Paris, 1: 1-258, 8 pls.

Bouvier, E. L.

1918. Sur une petite collection de crustaces de Cuba offerte au Museum par M. de Boury. Bull. Mus. Nat1. H1st. Nat., Par1s, 24: 6-15, 10 11gs,

Catesby, Mark

1743. The natural h1story of Carolina, Florida, and the Bahama Islands. London, 2: 1-xliv, $1-100$, 100 pls.

Chace, Fenner A, Jr.

1939. Preliminary descriptions of one new genus and seventeen now species of decapod and stomatopod crustacea. Reports on the scientific results of the P1rst Atlantic expedition to the West Indies, etc. Mem. Soc. Cub, Hist. Nat., 13(1): 31-54.

1956. Crustaceos decapodos y stomatopodos del arch1plelago de los rogues e isla de la orchila. In EI Arch1plelago de Los Rogues y La Orch1la. Soc. C1en. Nat. La Salle, pp. 145-168.

Coues, El110tt

1871. Notes on the natural history of Fort Macon, N. C., and vicinity. (No. 2). Proc. Acad. Nat. Se1. Ph1ladelph1a. 23: 120-148. 
Dana, James D.

1852. 0. S. Exploring Expedition during the years $1838,1839,1840,1841,1842$, under the command of Charles'w11kes, U. S. N. '13(1): 1-v111, 1685.

Fabric1us, V. C.

1798. Supplementum entomologiae systematicae. Hafniae, pp. 1-572. (Not seen).

Faxon, Walter

1893. Reports on the dredging operations off the west coast of Central America, etc. VI. Prelim1nary descriptions of new species of Crustacea. Bul1. Mus. Comp. Zool. Harvard, 24(7): 149-220.

1895. Reports on an exploration off the west coasts of Mexico, etc. XV. The stalk-eyed Crustacea. Mem. Mus. Comp. Zool. Harvard, 18; 1-292, il pls.

Forest, Jacques

1954a. Les Paguriates des cotes occ1dentales et merid1onales d'Afrique. Ann. South African Mus., 41 (4): $159-213,70$ 11gs., 1 pl.

1954b. Sur un Pagure littoral nouveau de la Martinique, Paguristes cadenat1 sp. nov. 26: 353-357, 3 figs.

G1bbes, Lewis

1850. On the carcinological collections of the United States, and an enumeration of species contained in them, with notes on the most remarkable, and descriptions of new species. Proc. Amer. Assoc. Adv. Se1., 32 167-201.

Glasse11, Steve A.

1938. New and obscure decapod Crustacea from the west American coasts. Trans. San Diego Soc. Nat. H1st., 8: 277-302, 4 flgs.

Gordan, Joan

1956. A b1bliography of pagurid orabs, exclusive of Alcock, 1905. Bull. Amer. Mus. Nat. H1st. 108(3): 253-352. 
Haas, Fritz

1950. Hermit crabs in Possil sna1l shells in Bermuda. Ecology, Lancaster, 31(1): 152.

Hay, W11l1am

1917. Preliminary description of five new species of crustaceans from the coast of North Carolina. Proc. B101. Soc. Washington, 30: 71-74.

Hed gpeth, Joel w.

1950a. Annotated 11st of certain marine invertebrates found on Texas jett1es. In H. L. Whitten, R11da F. Rosene, and J. W. Hedgpeth, the Invertebrate fauna of Texas coast jettles; a preliminary survey. Pub. Texas U. Inst. Mar. Sc1., 1(2): 53-86, 4 figs., 1 pl.

$1950 \mathrm{~b}$. Notes on the marine invertebrate fauna of salt flat areas in Aransas National Wildilfe Refuge, Texas. Publ. Inst. Mar. Sc1., 1(2): 103-119.

He1lprin, Angelo

1888. Contributions to the natural history of the Bermuda Islands. Proc. Acad. Nat. Sel. Phila, 40: $302-328,3$ pls. (Crustacea, pp. $318-328.)^{\prime}$

Henderson, James $\mathrm{R}$.

1888. Report on the Anomura collected by H. M. S. Challenger during the years 1873-76, Rept. 2001. Challenger Exped., 27: 1-221, 21 pls.

Herbst, Johann F. W.

1791. Versuch elner Naturgeschicte der Krabben und Krebse. Berlin, 2: 1-225, 25 pls.

H11debrand, Henry H.

1954. A study of the fauna of the brown shrimp (Penaeus artecus Ives) grounds in the western Gulf of Mexico. Pub. Texas U. Inst. Mar. Se1., $3(2), 233-366,7$ f1gs.

1958. Estudios biologicos prelininares sobre la Laguna Madre de Tamaulipas, Clencla (Mex.), 17(7-9): 151-173. 
H11gendorf, $F$.

1869. Crustaceen. In von der Decken's Reisen in Ost-Afrika. Leipzig and Heidelberg. 3: $66-116,6$ pls.

Holthuis, Lipke

1954. C. S. Rafinesque as a carcinologist, an annotated compliation of the information on Crustacea contalned in the works of that author. Zool. Verhandel. Rijksmus, Natuurl, Hist. Leiden, no. 23: $1-43,2$ pls.

Latre1lle, P. A.

1825. Familles naturelles du regne animal, etc. Paris, pp. $1-570$.

MacDonald, J. D., R. B. Plke, and D. I. Wllliamson

1957. Larvae of the Brit1sh species of D1ogenes, Pagurus, Ananagurus, and L1thodes (Crustacea, Decapoda) Proc, Zool. Soc. Lond on, 128(2): 209-257, il $11 \mathrm{gs}$.

Maerz, A. and $M_{\text {. R. Paul }}$

1950. A dictionary of color. MeGraw-H11l. New York, pp. 1-208, 56 pls.

Martens, E, von

1872. Ueber Cubanische Crustaceen nach den Sammlungen

Dr. J. Grundlach's Arch, I. Naturgesch., 38(i): 77-147, 2 pls.

Miers, Edward J.

1877. On a collection of Crustacea, Decapoda and Isopoda, chlefly from South America, with descriptions of now genera and species. Proc. Zool. Soc. Lond on, pp. 653-679, 4 pls.

M1lne Edwards, Alphonse

1880. Reports on the results of dredging. . . In the Gulf of Mexico, and in the Caribbean Sea, 1877, 1878, 1879, by the U. S. Coast Survey Steamer "BIake" . VIII. Etudes preliminalres sur les Crustaces. Buli. Mus. Comp. Zool. Harvard, 88 $1-68,2$ pls. 
Milne Edwards, A., and E. L. Bouvier

1892. Observat1ons preliminaires sur les Paguriens recueill1s par les expeditions du "Travallleurn et du "Tal1sman". Ann. Se1. Nat., 13: 185-226.

1893. Description des Crustaces de la Famille de Pagurlens recuellis pendant l'expedition. Pt. 33. Reports on the results of dredging. - by the U. S. Coast Survey Steamer "Blake". Mem. Mus. Comp. Zool. Harvard, 14(3), 1-172, 12 pls.

Milne Edwards, H.

1848. Note sur quelques nouvelles especes du genre Pagure. Ann. Se1. Nat., ser. 3, Zoo1., 10: 59-64.

Monod, Theodore

1939. Sur quelques Crustaces de la Guadeloupe (M1ssion P. Allorge, 1936), Bull. Mus, H1st. Nat. Par1s, ser. 2, 11: $557-568,11$ flgs.

Morelra, Carlos

1905. Campanhas de pesca do "Annie" Crustaceos. Arch. Mus. Nac., R10 de Jane1ro, 13: 123-145, 5 pls.

Neumann, R.

1878. Catalog der Podophthalmen Crustaceen des Heldelberger Museums. Le1pz1g, pp. 1-39.

Nicolet, Hercule

1849. In C. Gay, H1storla P1s1ca y pol1tica de Ch1le, Zoologia. Paris and Sant1ago, 3: 1-547. (Not seen).

011vier, M.

1811. Art. Pagure, In Encyclopedie Method1que, etc. Paris. (Not' seen).

Ortmann, Arnold $\mathrm{E}$.

1892. Die Decapoden-krebse des Strassburger Museums. IV. The11. D1e Abtheilungen Galatheidea und

Paguridea. Zool. Jahrb., Syst., 6: 24l-326, 2 pls. 
Pearse, Arthur s.

1932. Observations on the parasites and conmensals found assoclated with crustaceans and fishes at Dry Tortugas, Florlda. Papers Tortugas Lab., Carnegie Inst. Washington, 28, 103-115.

1951. Animals of the Black Rocks. In A. S. Pearse and L. G. Williams, The blota of the reefs off the Carolinas. Jour. Elisha Mitchell Sel. Soc., vol. 67 , pp. 133-161, 5 f1gs.

Rafinesque, C. $\mathrm{S}$.

1814. Precis de decouvertes et travaux somiologiques de Mr. C. S. Rafinesque- Schmaltz entre 1800 et 1814. Ou cholx ralsonne de ses principales decouvertes en zoologie et en botanique pour servir d'Introduction a ses ouvrages futurs. Palermo, pp. 1-55. (N

1817. Synopsis of four new genera and ten new specles of Crustacea found in the United States. Amer. Monthly Mag., New York, 2: 40-43.

Randall, J. W.

1839. Catalogue of the Crustacea brought by Thomas Nuttall and J. K. Townsend from the West Coast of North America and the Sandwich Islands, with deseriptions of such species as are apparently new, among which are included several spectes of different localities, previousiy existing in the collection of the Acadeny. Jour. Acad. Nat. Sc1. Ph1ladelphia, 8: 106-147, 4 pls.

Rankin, W11liam $\mathrm{M}$.

1910. The Northrop collection of Crustacea from the Bahamas. In Northrop, John L., A naturalist in the Bahamas. Memorlal volume; New York, Columb1a University Press, pp 69-96, 2 pls.

Rathbun, Mary J.

1897. List of the decapod Crustacea of Jama1ea. Annals, Inst. of Jama1ca, pp. 1-46.

1900. Results of the Branner-Agassiz expedition to Braz11. 1. The decapod and stomatopod Crustacea. Proc. Wash. Acad. Sc1., 2: 133-156, 1 pl. 
1919. Stalk-eyed crustaceans of the Dutch West Ind1es, collected by Dr. J. Boeke, 1904-1905. In Boeke, J., Rapport betreffende een voorloopig onderzoek naar den toestand van de V1sscher1j en de Industrie van Zeeproducten In de Kolon1e Curaca.. The Hague, pt. 2, pp. 317-349, 5 11gs.

R1dgway, Robert

1912. Color standards and nomenclature. Auth, pub. Washington, pp. 1-43, $53 \mathrm{pls}$.

Saussure, H. de

1858. Memolre sur d1vers crustaces nouveaux des Ant1lles et du Mexique. Mem. Soc. Phys. Hist.

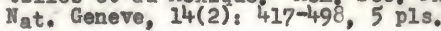

Say, Thoma's

1817. An account of the Crustacea of the Un1ted States, Jour. Acad. Nat. Sc1. Philadelphia, I(2): i55-169.

Schmitt, Waldo L.

1924a. Report on the Macroura, Anomura and Stomatopoda collected by the Barbados- Ant1gua expedition irom the University of Iowa in 1918. Univ. Iowa Studies, 10(1): $65-99,5 \mathrm{pls}$.

1924b. B1jaragen tot de kennis der fauna van Curacao. Resultaten eener re1s van der Horst in 1920. The macruran, anomuran and stomatopod Crustacea. Bijâr. Dierk., 23:.61-81, 7 11gs, 1 pl.

1933. Four new specles of decapod crustaceans from Porto Rico. Amer. Mus, Nov1tates, no. 662, pp. $1-9,4$ rigs.

1935. Crustacea Macrura and Anomura of Porto R1co and the V1rgin Isiands. Sclentific survey of Porto Rico and the V1rgin Islands. Nev York, New York Academy of Sclences, 15, 125-227, 78 flgs., 2 maps.

1936. Macruran and anomuran Crustacea from Bonalre, Aruba and Curacao, Zool. Jahrb. Syst. Geogr. B101., 67: 363-378, 3 pls. 
Smith, Sidney $I$.

1879. Crustacea of the Atlantic coast of North

America. Trans. Connecticut Acad. Arts and Sc1., 5: 27-136, 5 pls.

1881. Preliminary notice of the Crustacea collacted off the south coast of New England by the U. s. Nat. Mus., 3: 413-452.

1883. Preliminary report on the Brachyura and Anomura dredged in deep water off the south coast of New England by the U. S. Fish Commission in 1880 , 1881, and 1882. Proc. U. S. Nat. Mus., 6: 1-57, 6 pls.

Springer, Stewart, and $\mathrm{H} . \mathrm{R}$. Bull1s, Jr.

1956. Collections by the "Oregon" in the Gulf of Mexico. Spec. Sclent. Report: F1sheries, Wash1ngton, No. 196, pp. 1-134.

Stimpson, W1111am

1858. Prodromus deseriptionis animalium evertebratorum, quae in Expeditione ad Oceanum Paciflcum Septentrionalem, a Republica Federata missa, Cadwaladaro RInggold et Johanne Rodgers duclbus, observavit et descripsit. Pars VII. Crustacea Anomura. Proc. Acad. Nat. Sc1. Philadelphia, 10: 225-252.

1859. Notes on North American Crustacea No. 1. Ann. Lyc. Nat. H1st. New York, 7, 176-246, 2 pls.

1860. Notes on North American Crustacea, in the Museum of the Smithsonian Institution. Iro. II. Ann. Lyc. Nat. H1st., 7: 176-246, 2 pls.

Studer, T.

1883. Verzelchniss der wahrend der Reise S. M. S. 'Gazelle' an der Westkuste von Africa, Aseension, und dem Cap der guten Hoffnung gesammelten Crustaceen. Abhand1. Akad. WIssensch. Berlin, pp. 1-32, 2 pls.

Torralbas, Frederico

1917. Contribucion alestudio de los crustaceos de Cuba. Notas del Dr. Juan Gundlach 1896. Compiladas y completadas por el Dr. Jose I. 


$$
274 .
$$

Torralbas 1903. An. Acad. C1en. Med., F1s. Nat. Habana, 53: 543-624, 73 f1gs.

Verr111, A. E.

1908. Decapod Crustacea of Bermuda; I. Brachyura and Anomura. Their distribution, varlations, and hab1ts. Trens. Connect1cut Acad. Arts and Sc1., 13: 299-473, 67 11gs., 20 pls.

Wass, Marvin L.

1955. The decapod erustaceans of Alligator Harbor and adjacent inshore areas of northwestern Florlda, Quart. Jour. Florida Acad. Se1., 18: 129-176, 13 f1gs.

W1111amson, H. C.

1915. Crustacea Decapoda, Larven. In Brandt, K., and C. Apstein (Eâs. ), Nordisches Plankton. $\mathrm{K} 1 \mathrm{l} \mathrm{I}$ and LelpzIg, Lipsius und T1scher, Zoolog1scher Te11, 3: 315-588.

Yokoya, Y.

1933. On the distribution of decapod crustaceans Inhabiting the continental shelf around Japan, chlefly based upon the materials collected by S. S. Soyo-Maru during the years 1923-1930. Jour. College Agr. Tokyo, 12(1): 1-226, 71 11gs. 


\section{PLATE I}

All lines indicate $5.0 \mathrm{~mm}$.

Figure 1. Anterfor head appendages and carapace of Prlocheles Inarmatus.

F1gure 2. Right chela and part of carpus of $P$. Inarmatus.

F1gure 3. Median posterior part of abdomen of P. Inarmatus. 
PLATE I

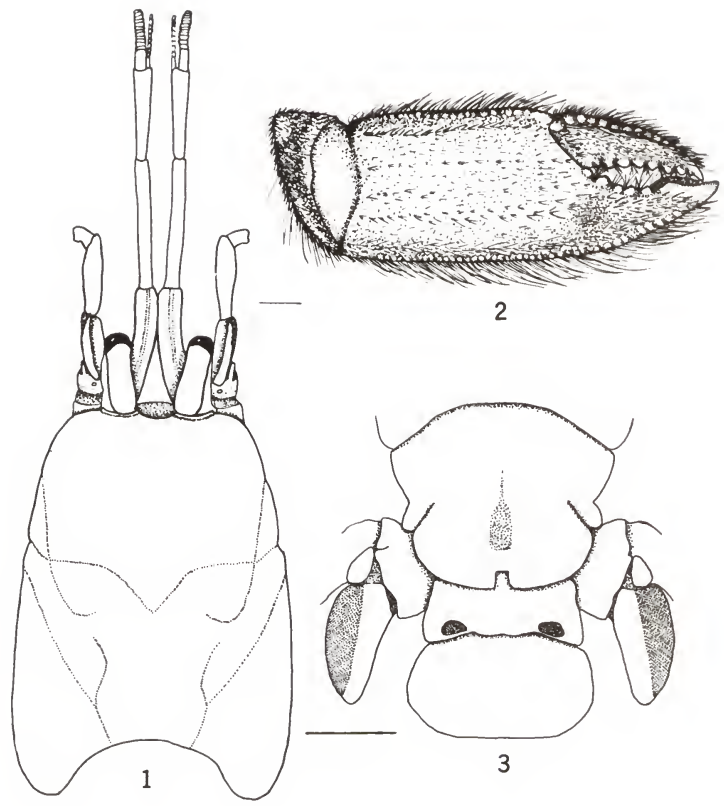


PLATE II

First gonopod of Pazucistoosis humis and 14 species of Pagu1stes. All from right side except No. 1. Lines indicate length of $0.5 \mathrm{~mm}$.

F1gure 1. Paguristes forest1.

F1gure 2. Paguristes spinioes.

F1gure 3. Paguristes tortugae.

Figure 4. Paguristes hematt1.

F1gure 5. Paguristes triangulatus.

Figure 6. Paguristonsis bumm1.

F1gure 7. Paguristes eravi.

Figure 8. Paguristes puncticens.

F1gure 9. Paguristes sericeus.

Pigure 10. Paguristes savi.

F1gure 11. Paguristes lmand.

F1gure 12. Paguristes meore1.

Figure 13. Paguristes denressus.

F1gure 14. Paguristes anomains.

Figure 15. Paguristes acuticornis. 
276.

PIATE 2
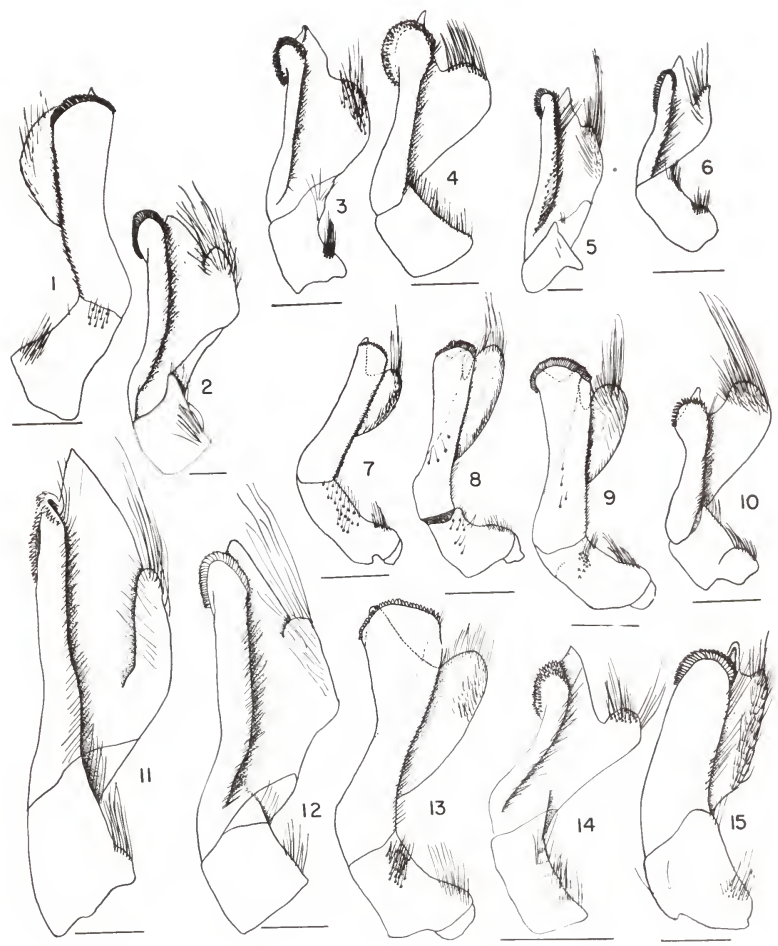


\section{PLATE III}

Second gonopod of Peguristonsis humm and 14 species of PaguIistes. All from right slde except No. 9. Lines Indicate length of $0.5 \mathrm{~mm}$.

Figure 1. Paguristoosis humn1.

F1gure 2. Paguristes triangulatus.

Figure 3. Paguristes sar1.

Figure 4. Paguristes soinives.

F1gure 5. Paguristes moore1.

F1gure 6. Pagur1stes hewatt1.

Flgure 7. Paguristes tortugae.

F1gure 8. Pagur1stes anomalus.

Figure 9. Pagur1stes rorest1.

F1gure 10. Paguristes Irman1.

r1gure 11. Paguristes acuticornis.

Figure 12. Paguristes sericeus.

F1gure 13. Paguristes nunct1cens.

F1gure 14. Paguristes grap1.

Figure 15. Paeuristes devressus. 
277.

PLATE 3

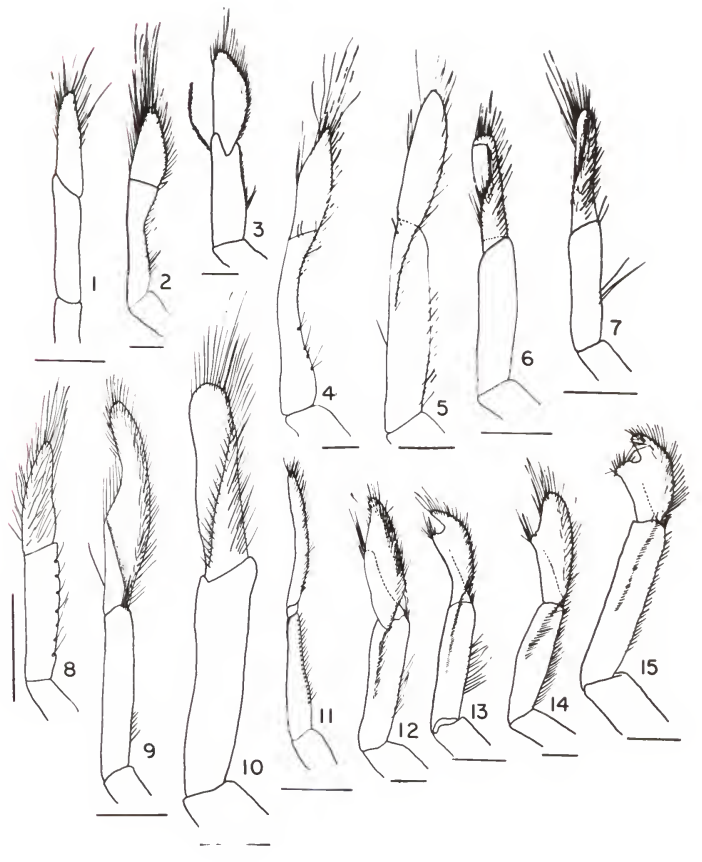




\section{PLATE IV}

All lines 1ndicate $2.0 \mathrm{~mm}$.

F1gure 1. Right carpus and chela of P. hewatt1.

F1gure 2. Anterior head appendages and shield of Pagurus schmitt1.

Figure 3. Right chola of $P$. schmitt1.

F1gure 4. Anter1or head appendages and shleld of CeratoDagurus eubensts.

Figure 5. Anterior head appendages and shleld of Pagurus tenuldactrlus. 
278.

PLATE 4
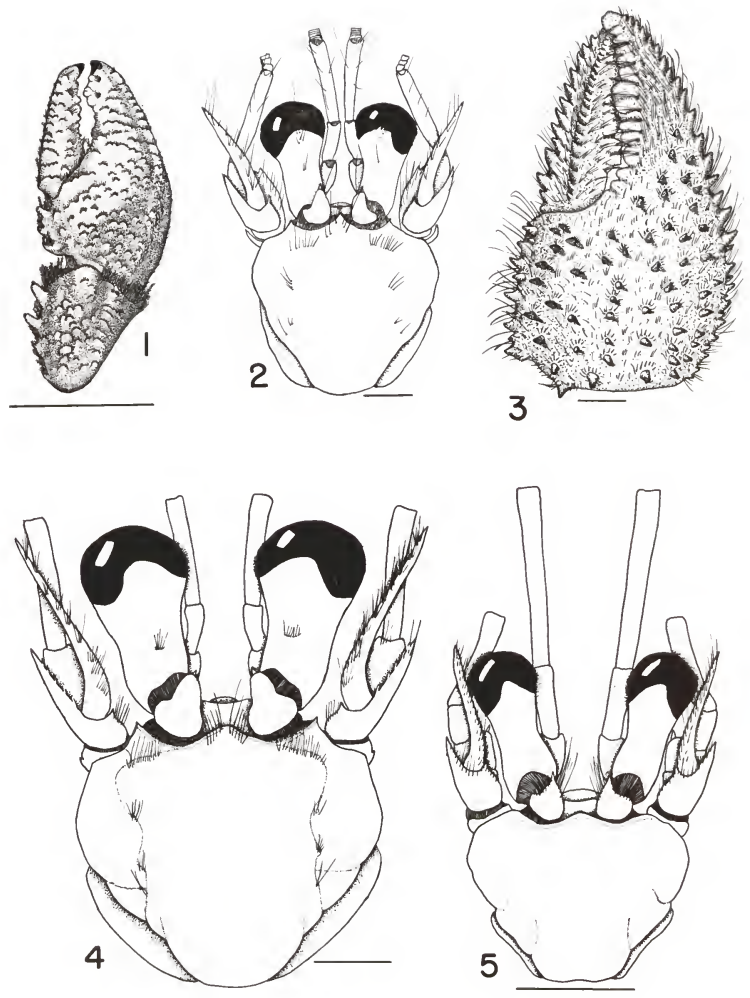


\section{PLATE V}

All IInes Indicate $1.0 \mathrm{~mm}$.

Figure 1. Anterlor head appendages and shield of Pagurus longimanus.

Figure 2. Right chela of Pagurus longimanus.

F1gure 3. Anterlor head appendages and shleld of Cestopagurus jineatus.

Figure 4. Ventral view of abdomen of $\mathrm{C}$. Wineatus show Ing protruding vas deferens. 
PLATE 5
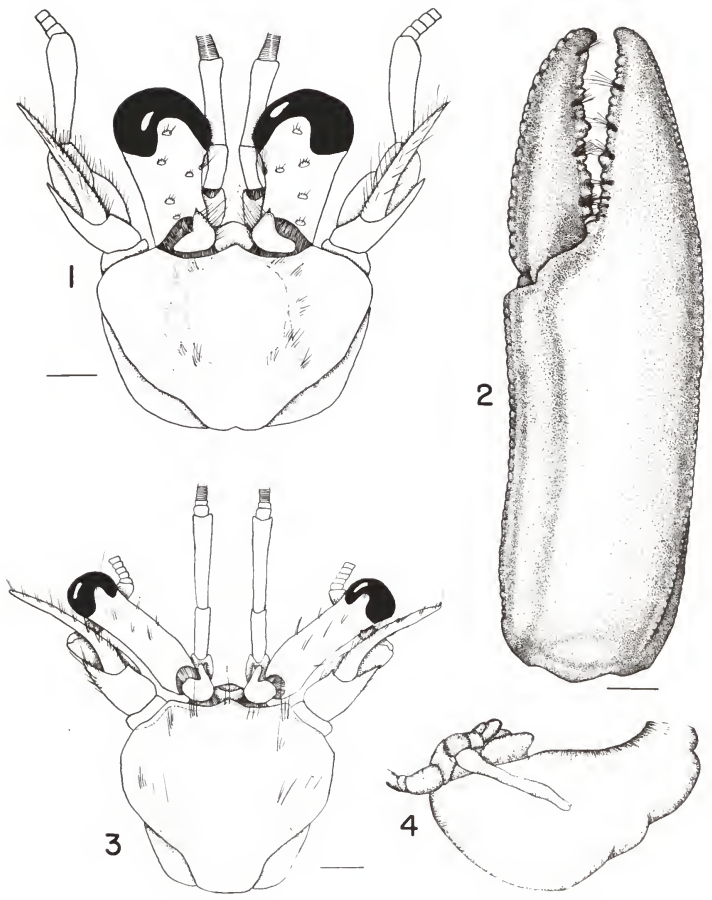


\section{BIOGRAPHICAL SKETCH}

Marvin L. Wass was born Apr11 24, 1922, in WorthIngton, Minnesota. He attended high school at Pequot Lakes, MInnesota. From September, 1942, to December, 1945, he served with the Army A1r Corps in the United States and North Africa.

He recelved the Bachelor of Sclence degree from Winona State Teacher's College, Winona, Minnesota, in 1949, and the Master of Selence degree in Zoology from The Florida State University In 1953. From June, 1953, to May, 1955, he worked for the Pinellas County Park Board as Curator of the Mullet Key Marine Museum, Passa-Grille Beach, Florida.

His research interests have been in carcinology and ornithology. H1s principal published work was on the decapod Crustacea of All1gator Harbor and adjacent regions of northwest Florida. He is a member of Sigma $X_{1}$.

Ho was marrled to Lorna Kathryn Cowle in 1955. They have two chlldren, Gerald and Teresa. 
This dissertation was prepared under the direction of the chairman of the candidate's supervisory committee and has been approved by all members of the committee. It was submitted to the Dean of the College of Arts and Sciences and to the Graduate Counc1l and was approved as partial fulf1llment of the requirements for the degree of Doctor of Philosophy.

June 8, 1959

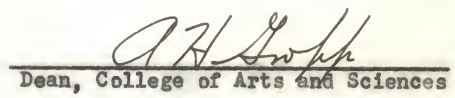

Dean, Graduate School

SUPERVISORY COMMITTEE:
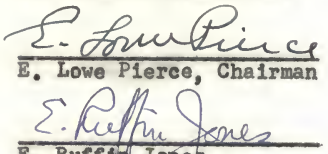

B. Rurfin Jone $\beta$
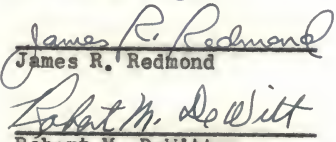

Robert $M_{0}$ Dew1tt

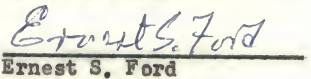

